\title{
Evaluation of Boulder, CO, SmartRegs Ordinance and Better Buildings Program
}

L. Arena and G. Vijayakumar

Consortium for Advanced Residential Buildings (CARB) 


\title{
NOTICE
}

This report was prepared as an account of work sponsored by an agency of the United States government. Neither the United States government nor any agency thereof, nor any of their employees, subcontractors, or affiliated partners makes any warranty, express or implied, or assumes any legal liability or responsibility for the accuracy, completeness, or usefulness of any information, apparatus, product, or process disclosed, or represents that its use would not infringe privately owned rights. Reference herein to any specific commercial product, process, or service by trade name, trademark, manufacturer, or otherwise does not necessarily constitute or imply its endorsement, recommendation, or favoring by the United States government or any agency thereof. The views and opinions of authors expressed herein do not necessarily state or reflect those of the United States government or any agency thereof.

Available electronically at http://www.osti.gov/bridge

\author{
Available for a processing fee to U.S. Department of Energy \\ and its contractors, in paper, from: \\ U.S. Department of Energy \\ Office of Scientific and Technical Information \\ P.O. Box 62 \\ Oak Ridge, TN 37831-0062 \\ phone: 865.576 .8401 \\ fax: 865.576 .5728 \\ email: mailto:reports@adonis.osti.gov \\ Available for sale to the public, in paper, from: \\ U.S. Department of Commerce \\ National Technical Information Service \\ 5285 Port Royal Road \\ Springfield, VA 22161 \\ phone: 800.553 .6847 \\ fax: 703.605.6900 \\ email: orders@ntis.fedworld.gov \\ online ordering: http://www.ntis.gov/ordering.htm
}




\title{
Evaluation of Boulder, CO, SmartRegs Ordinance and Better Buildings Program
}

\author{
Prepared for: \\ Building America \\ Building Technologies Program \\ Office of Energy Efficiency and Renewable Energy \\ U.S. Department of Energy \\ Prepared by: \\ Lois Arena and Gayathri Vijayakumar \\ Steven Winter Associates, Inc. of the \\ Consortium for Advanced Residential Buildings (CARB) \\ 61 Washington Street \\ Norwalk, CT 06854 \\ NREL Technical Monitor: Cheryn Engebrecht \\ Prepared under Subcontract No. KNDJ-0-40342-02
}

April 2012 
\begin{tabular}{l|l} 
u.s. DEPARTMEnt of & Energy Efficiency \& \\
ENERCY & Renewable Energy
\end{tabular}

[This page left blank] 


\section{Contents}

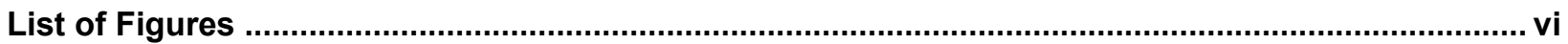

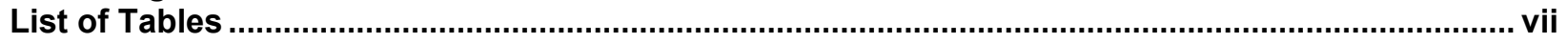

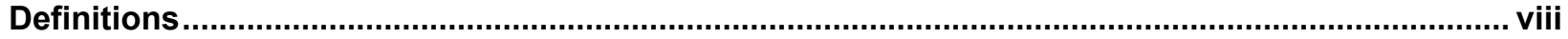

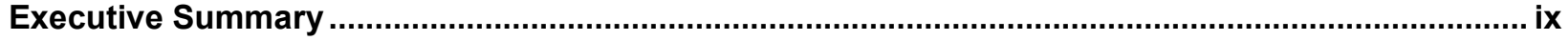

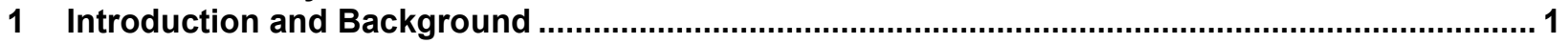

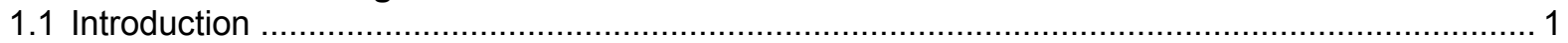

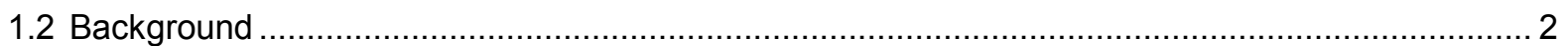

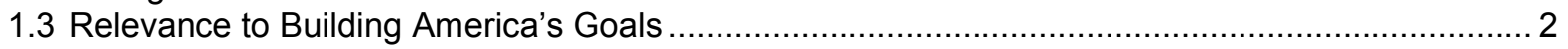

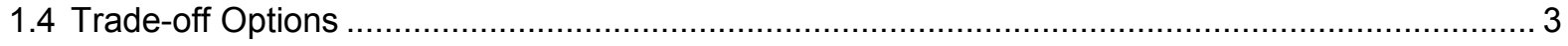

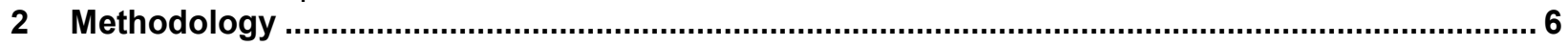

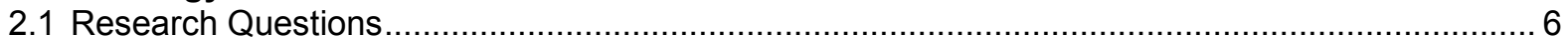

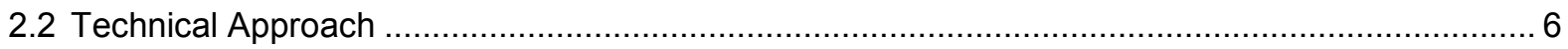

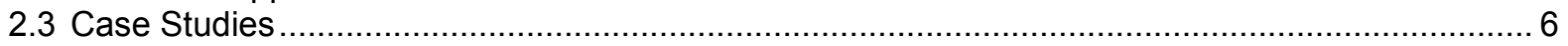

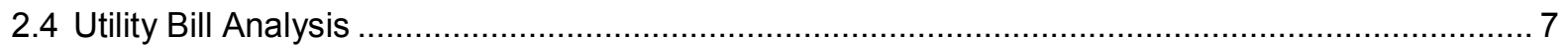

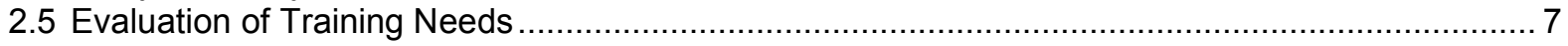

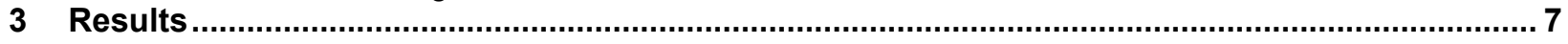

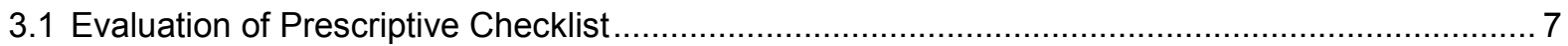

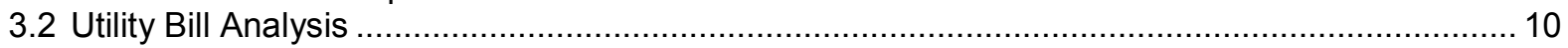

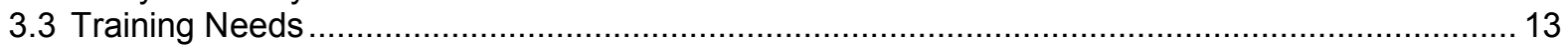

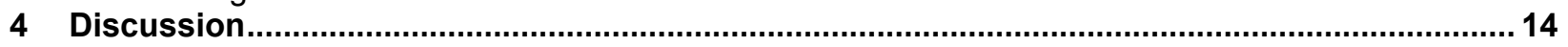

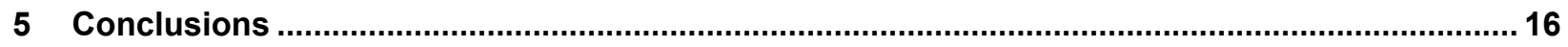

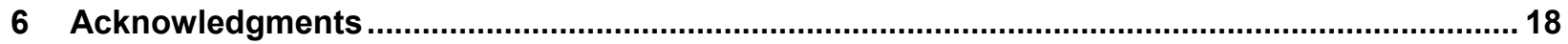

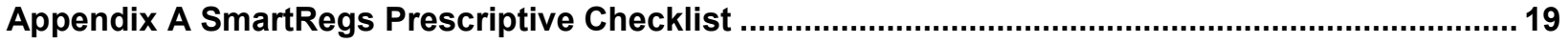

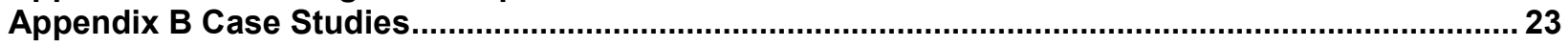

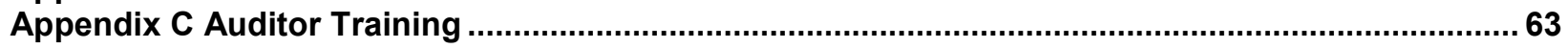

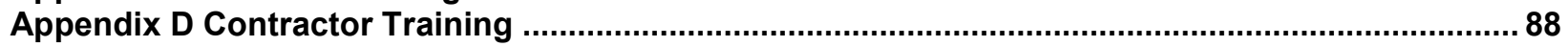

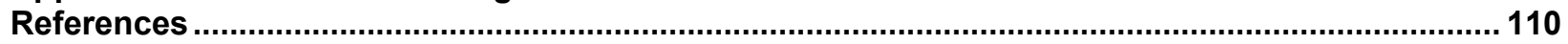




\section{List of Figures}

Figure 1. Section of Boulder, CO's prescriptive pathway checklist used for determining SmartRegs compliance (page 1 of 3 )

Figure 2. Example of walls section of SmartRegs checklist for a home where $\mathbf{5 0 \%}$ of the walls are uninsulated and $\mathbf{5 0 \%}$ are insulated to $\mathbf{R}-\mathbf{1 3}$. This home would gain 10 points from the walls section.

Figure 3. Scatter plot showing the correlation between the HERS Index and the SmartRegs prescriptive checklist score for the pre-retrofit cases.

Figure 4. Scatter plot showing the correlation between the HERS Index and the SmartRegs prescriptive checklist score for the actual and recommended post-retrofit cases..................... 9

Figure 5. Monthly electric utility use (kWh) for a sample of 1-bedroom units for the property in case study \#8.

Figure 6. Monthly natural gas use (therms) for a sample of 1-bedroom units for the property in case study \#8.

Figure 7. Predicted annual electricity use $\left(\mathrm{kWh} / \mathrm{ft}^{2}\right)$ for the models types with available pre-retrofit utility bills

Figure 8. Predicted annual natural gas use (therms $/ \mathrm{ft}^{2}$ ) for the models types with available preretrofit utility bills.

Unless otherwise noted, all figures were created by CARB. 


\section{List of Tables}

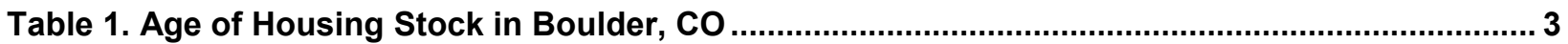

Table 2. Age of Rental Housing Stock in U.S.

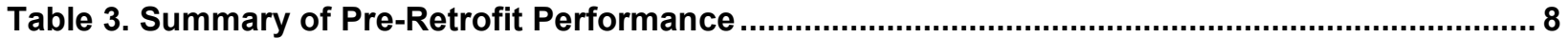

Table 4. Summary of Post-Retrofit or Recommended Post-Retrofit Performance ........................... 9

Table 5. Summary of Predicted Savings............................................................................................ 10

Table 6. SmartRegs Prescriptive Checklist Scores: SmartRegs Inspector vs. CARB

Audit Results.

Unless otherwise noted, all tables were created by CARB. 


\section{Definitions}

\begin{tabular}{ll} 
ARRA & American Reinvestment and Recovery Act \\
BA & Building America \\
CAP & Climate Action Plan \\
DOE & Consortium for Advanced Residential Buildings \\
EGUSA & Department of Energy \\
GHG & EnergyGauge USA \\
HERS & Greenhouse gas \\
HUD & Home Energy Rating System \\
JCHS & Department of Housing and Urban Development \\
NMHC & Joint Center for Housing Studies \\
NREL & National Multi Housing Council \\
RESNET & National Renewable Energy Laboratory \\
SWA & Residential Energy Services Network \\
\hline
\end{tabular}




\section{Executive Summary}

In 2002, the City of Boulder, Colorado, adopted a Climate Action Plan (CAP) with the goal of reducing greenhouse gas emissions to 7\% below 1990 levels by 2012 . Since adoption of this plan, Boulder's greenhouse gas (GHG) emissions have increased. Although it is unlikely that the 2012 goal will be realized, their 2020 goal is still attainable if aggressive action is taken. Boulder's SmartRegs ordinance and involvement in the U.S. Department of Energy's (DOE) Better Buildings program are critical pieces of this equation.

The SmartRegs Ordinance was adopted by the City of Boulder on September 21, 2010, and went into effect on January 3, 2011. It is a mandate requiring all rental property owners to bring their rentals up to a minimum energy efficiency standard by 2019 (approximately equivalent to a HERS Index of 120). Considering that Boulder's housing stock includes approximately 20,000 rental units (almost 50\% of Boulder's total housing stock), and audits conducted in 2011 showed current HERS indices between 100 and 192, the resulting energy savings are expected to be significant.

In combination with the SmartRegs Ordinance, the City of Boulder applied for and was granted an award from the DOE's Better Buildings initiative. Under this program, Boulder received a $\$ 12$ million grant that they used to create and incentivize their EnergySmart Program. The program's strategy centers around an energy advisor who works with the homeowner during the visit to close a retrofit sale on the spot if upgrades are recommended. This service is seen as a key strategy for actually meeting the City's goals. To assist homeowners with upgrades, rebates and loans are offered through the EnergySmart program.

Performance targets for the EnergySmart program include improving 10,000 homes and 3,000 businesses by May 2013, while stimulating economic growth and investment in energy efficiency in the state of Colorado. SmartRegs goals for 2013 include having 9,000 rental units participate in their program with 4,500 of those being brought into compliance. As of December 2011, 3,374 homes had enrolled in EnergySmart. More than 1,500 rental properties have signed up for SmartRegs, with over 900 already achieving compliance.

Evaluating, improving and promoting retrofit programs like Boulder's SmartRegs ordinance could lead to energy efficiency improvements for millions of residential rental units across the United States and result in lower gross rents for much of the country's rental population. Of the approximately 34 million rental units in the United States, more than 24 million were built before 1980 and consequently, to those efficiency levels. These statistics suggest an enormous opportunity for energy reduction in rental units in this country.

To evaluate the SmartRegs program, the Consortium for Advanced Residential Buildings (CARB), a DOE Building America research team, performed a number of tasks. Nine full audits were conducted (12 individual units) with the intention of comparing the paths for compliance: performance based vs. a prescriptive checklist. Improvement packages that resulted in compliance with the prescriptive checklist often resulted in a HERS Index less than 120, further supporting the prescriptive approach as a favored and equally high-performing route to compliance with the ordinance. 
Inspections conducted by the original auditors were evaluated, which allowed CARB to identify opportunities for improving trainings and potential revisions to the checklists. Based on these evaluations, CARB worked with city planners and administrators to develop building science training for both insulators and inspectors (see Appendix). In addition, interviews were conducted with property owners to determine what they viewed as the barriers to successful implementation. 


\section{Introduction and Background}

\subsection{Introduction}

Under the SmartRegs ordinance, all rental properties in Boulder, Colorado, must achieve an energy efficiency level comparable to a HERS Index of approximately 120 points or lower by the year 2019. By requiring a minimum level of energy performance, it is intended that compliance with SmartRegs will result in a much more efficient residential rental housing stock.

To ensure program goals are met, and to aid property owners in navigating the compliance process, the City of Boulder and the SmartRegs program administrators developed the EnergySmart Advisors service with the use of funds from the Better Buildings program, a program under the American Recovery and Reinvestment Act (ARRA). The service provides a Home Energy Assessment and access to free Energy Advisors who help make decisions on the most cost-effective energy efficiency measures and assist with rebate paperwork and contractor selection.

The intention of the Better Buildings funding was to improve the energy performance of existing buildings and to start building a new generation of energy efficient buildings. ${ }^{1}$ And, as stated later in this report, a key goal of the Building America program is to reduce energy use in existing homes by $30 \%-50 \%$ compared to pre-retrofit energy use. In order to meet these goals, accurate analysis and prediction of the energy use of existing buildings is essential, but multiple studies confirm that analysis methods tend to overpredict energy use in poorly insulated, leaky homes and thus, the savings associated with improving those homes (Polly et. al. 2011).

In NREL's report titled "Assessing and Improving the Accuracy of Energy Analysis of Residential Buildings", researchers propose a method for improving the accuracy of residential energy analysis methods. A key step in this process involves the comparisons of predicted versus metered energy use and savings. The SmartRegs ordinance in Boulder will result in available pre- and post-retrofit utility bills and building efficiency levels, thus providing valuable data to aid in improving the accuracy of residential energy analysis methods. Due to retrofit schedules and difficulty obtaining these bills from the local utility, this data was not available for this report.

Performance targets for 2013 for the SmartRegs ordinance include having had 9,000 rental units participate in the EnergySmart program with 4,500 of those being brought into compliance. With similar programs being developed across the country and the current administration's focus on large-scale retrofit activities, knowledge gained from Boulder's project could significantly impact the accuracy and decision process of others.

\footnotetext{
${ }^{1}$ http://www.whitehouse.gov/the-press-office/2011/02/03/president-obama-s-plan-win-future-making-americanbusinesses-more-energy
} 


\subsection{Background}

National Multi Housing Council (NMHC) tabulations of the 2010 Current Population Survey estimate that $33 \%$ of U.S. households are renters. ${ }^{2}$ Roughly $53 \%$ of those households rent a single-family home or live in a structure with less than four units.

According to research conducted by the Joint Center for Housing Studies (JCHS) of Harvard University, over the past decade, the number of renter households has held more or less steady at 34 million. During that time, gross rents (rents plus utility costs) have been increasing faster than inflation and now stand at an all-time high. With the recent jump in energy costs, gross rents are certain to head even higher.

The JCHS forecasts that, even as growing numbers of households move into homeownership, rental housing will remain an important resource for families and individuals of all types-from new immigrants to aging baby boomers. "And for the nation's households of little or no means, decent and affordable rental housing will provide the security and stability necessary to improve upon their circumstances" (JCHS 2006).

Given the above statistics, evaluating, improving and promoting retrofit programs like Boulder's SmartRegs ordinance could lead to energy efficiency improvements for millions of residential rental units across the United States and result in lower gross rents for much of the country's rental population.

\subsection{Relevance to Building America's Goals}

Overall, the goal of the U.S. Department of Energy's (DOE) Building America program is to "reduce home energy use by 30\%-50\% (compared to 2009 energy codes for new homes and preretrofit energy use for existing homes)." To this end, the CARB team conducts research to "develop market-ready energy solutions that improve efficiency of new and existing homes in each U.S. climate zone, while increasing comfort, safety, and durability." ${ }^{3}$ Given that $33 \%$ of U.S. households are renters, improving the efficiency of rental properties is a key step in achieving these goals.

In towns and cities like Boulder where the rental population is higher than the national average of $33 \%$, the opportunity for energy reductions is even greater. According to the U.S. Census Bureau data displayed in Table 1, approximately $51 \%$ of Boulder's housing stock is renter occupied, and of that, almost $70 \%$ was constructed before 1980 . Therefore, by requiring property owners to upgrade rental properties, the SmartRegs program aids in advancing Boulder's community sustainability objectives, and will hopefully result in increased comfort, better indoor air quality and lower energy bills for tenants.

\footnotetext{
${ }^{2}$ http://www.nmhc.org/Content/ServeContent.cfm?ContentItemID=1152\#us_househols_renters and owners

${ }^{3}$ http://www1.eere.energy.gov/buildings/building_america/program_goals.html
} 
Table 1. Age of Housing Stock in Boulder, CO

\begin{tabular}{|l|c|c|c}
\hline Housing Stock & $\begin{array}{c}\text { Estimated } \\
\text { total occupied } \\
\text { housing units }\end{array}$ & $\begin{array}{c}\text { Estimated } \\
\text { owner- } \\
\text { occupied } \\
\text { housing units }\end{array}$ & $\begin{array}{c}\text { Estimated } \\
\text { renter- } \\
\text { occupied } \\
\text { housing units }\end{array}$ \\
\hline Occupied housing units & 39,893 & 18,716 & 21,177 \\
UNITS IN STRUCTURE & $44.7 \%$ & $71.4 \%$ & $21.1 \%$ \\
\hline 1, detached & $7.7 \%$ & $10.2 \%$ & $5.5 \%$ \\
\hline 1, attached & $2.5 \%$ & $0.3 \%$ & $4.4 \%$ \\
\hline apartments & $7.1 \%$ & $3.1 \%$ & $10.5 \%$ \\
3 or 4 apartments & $6.6 \%$ & $2.8 \%$ & $9.9 \%$ \\
\hline 5 to 9 apartments & $28.3 \%$ & $5.9 \%$ & $48.0 \%$ \\
\hline 10 or more apartments & $3.3 \%$ & $6.3 \%$ & $0.6 \%$ \\
\hline Mobile home or other type of housing & & & \\
YEAR STRUCTURE BUILT & $9.5 \%$ & $12.1 \%$ & $7.3 \%$ \\
\hline 2000 or later & $11.0 \%$ & $12.7 \%$ & $9.4 \%$ \\
\hline 1990 to 1999 & $13.8 \%$ & $13.7 \%$ & $13.8 \%$ \\
\hline 1980 to 1989 & $43.1 \%$ & $40.9 \%$ & $45.1 \%$ \\
\hline 1960 to 1979 & $13.5 \%$ & $12.5 \%$ & $14.4 \%$ \\
\hline 1940 to 1959 & $9.1 \%$ & $8.1 \%$ & $10.0 \%$ \\
\hline 1939 or earlier
\end{tabular}

Reproduced from U.S. Census Bureau, American Community Survey:

http://factfinder2.census.gov/faces/tableservices/jsf/pages/productview.xhtml?fpt=table

Table 2 displays the age distribution of the rental housing stock in the United States as reported by the U.S. Census Bureau. According to that data, $70 \%$ of the nation's rental housing stock is more than 30 years old (HUD 2011), very much in line with Boulder's statistics. This means that, of the approximately 34 million rental units in the United States, more than 24 million were built before 1980 and consequently, to those efficiency levels.

Table 2. Age of Rental Housing Stock in U.S.

\begin{tabular}{|c|c|c}
\hline Year Built & Distribution of Units & \# Constructed \\
\hline & {$[\%]$} & [thousands] \\
\hline $2005-2009$ & 3.6 & 1,283 \\
$2000-2004$ & 4.9 & 1,731 \\
1990 to 1999 & 8.2 & 2,883 \\
1980 to 1989 & 13.2 & 4,668 \\
1960 to 1979 & 35.3 & 12,491 \\
Before 1960 & 34.8 & 12,321 \\
\hline
\end{tabular}

Source: American Housing Survey for the US, 2009.

\subsection{Trade-off Options}

Compliance with Boulder's SmartRegs ordinance can be met through either a performance or prescriptive path. The performance path requires a comprehensive energy audit: measurements of all building dimensions and individual components, air leakage and duct leakage testing, and energy modeling to produce a HERS Index. If the rental unit receives a HERS Index of 120 or 
less, it is considered to be in compliance with the ordinance. A HERS rating can only be performed by a RESNET-accredited energy rater.

The prescriptive path involves a slightly less comprehensive audit: fewer measurements are required, duct leakage testing is not required and energy modeling is not necessary. Contractors performing SmartRegs inspections using the prescriptive path must be a licensed general contractor, architect or engineer, or a certified inspector and have gone through a city sponsored training program.

When creating the prescriptive checklist, the developers set out to create a threshold that would apply to all homes. After extensive analysis, it was determined that 100 points on the checklist should correspond to a HERS Index of 120, more or less. Since a lower HERS Index is more desirable than a higher one, and a higher SmartRegs score is better than a lower one, the two paths are inversely related. A section of the checklist is displayed in Figure 1. The full checklist is located in the Appendix.

\begin{tabular}{|c|c|c|c|c|}
\hline \multicolumn{5}{|c|}{ SmartRegs Prescriptive Pathway } \\
\hline WALLS & \multicolumn{2}{|c|}{ Base: } & \multicolumn{2}{|c|}{ Final: } \\
\hline R-VALUE & $25 \%$ & $\mathbf{5 0} \%$ & $75 \%$ & $100 \%$ \\
\hline No Insulation & 0 & 0 & 0 & 0 \\
\hline $\begin{array}{l}\text { R-3 Continuous (must be at } \\
\text { least R-3) }\end{array}$ & 3 & 6 & 9 & 12 \\
\hline R-5 Continuous & 4 & 8 & 12 & 15 \\
\hline $\begin{array}{l}\mathrm{R}-13 \text { or Uninsulated } \\
\text { Basement Wall }\end{array}$ & 5 & 10 & 15 & 20 \\
\hline R-19 or Better & 5 & 11 & 16 & 21 \\
\hline $\begin{array}{l}\text { Shared Wall or Insulated } \\
\text { Basement Wall }\end{array}$ & 6 & 13 & 19 & 26 \\
\hline
\end{tabular}

\section{SLAB / FOUNDATION Base: Final:}

\begin{tabular}{|c|c|c|c|c|}
\hline \multicolumn{5}{|c|}{ SLAB ON GRADE } \\
\hline TYPE & $25 \%$ & $50 \%$ & $75 \%$ & $100 \%$ \\
\hline Slab Edge: R-0 & 2 & 3 & 5 & 6 \\
\hline Slab Edge: R-5 & 2 & 4 & 5 & 7 \\
\hline $\begin{array}{l}\text { Slab Edge: R-10 or } \\
\text { Better }\end{array}$ & 2 & 4 & 6 & 8 \\
\hline $\begin{array}{l}\text { Slab Edge R-10 plus } \\
\text { Under Slab R-10 or } \\
\text { Better }\end{array}$ & 3 & 6 & 8 & 11 \\
\hline
\end{tabular}

$\begin{array}{ccccc}\text { Basement Slab } & 2 & 4 & 6 & 8 \\ \text { FOUNDATION WALLS (Crawlspace) }\end{array}$

\begin{tabular}{|lcccc|}
\hline \begin{tabular}{l} 
WINDOWS/FENESTRATION \\
\multicolumn{1}{c}{ TYPE }
\end{tabular} & $\mathbf{2 5 \%}$ & $\mathbf{5 0 \%}$ & $\mathbf{7 5 \%}$ & $\mathbf{1 0 0 \%}$ \\
\hline $\begin{array}{l}\text { Single Metal } \\
(1.2 \text { U-Value })\end{array}$ & 0 & 0 & 0 & 0 \\
\hline $\begin{array}{l}\text { Single Non-Metal } \\
\text { (.95 U-Value) }\end{array}$ & 0 & 1 & 1 & 2 \\
\hline $\begin{array}{l}\text { Double Metal } \\
\text { (.8 U-Value) }\end{array}$ & 1 & 2 & 3 & 4 \\
\hline $\begin{array}{l}\text { Double Non-Metal }{ }^{*} \\
\text { (.55 U-Value) }\end{array}$ & 2 & 3 & 5 & 6 \\
\hline 0.35 U-Value & 3 & 7 & 10 & 13 \\
\hline 0.30 U-Value & 3 & 7 & 10 & 14 \\
\hline 0.25 U-Value or Better & 4 & 7 & 11 & 14 \\
\hline
\end{tabular}

\begin{tabular}{|lllll|}
\hline R-0 & 0 & 0 & 0 & 0 \\
\hline R-2 & 2 & 3 & 5 & 6 \\
\hline R-11 & 2 & 4 & 6 & 8 \\
\hline R-19 or Better & 2 & 5 & 7 & 9 \\
\hline
\end{tabular}

FLOOR

(Only Available if No Ducts or HVAC Equipment are Located in Uninsulated Crawlspace Below Floor)

\begin{tabular}{lcccc|}
\hline Floor Over Crawl: R-0 & 0 & 0 & 0 & 0 \\
\hline Floor Over Crawl: R-13 & 3 & 5 & 8 & 11 \\
\hline Floor Over Crawl: R-25 & 3 & 6 & 9 & 12 \\
\hline $\begin{array}{l}\text { Floor Over Crawl: R-38 } \\
\text { or Better }\end{array}$ & 4 & 7 & 11 & 14 \\
\hline Shared Floor & 4 & 8 & 11 & 15 \\
\hline
\end{tabular}

\begin{tabular}{|lcccc|}
\hline \multicolumn{1}{|c}{ ATTIC } & \multicolumn{2}{c}{ Base: } & \multicolumn{2}{c|}{ Final: } \\
\hline TYPE & $\mathbf{2 5 \%}$ & $\mathbf{5 0 \%}$ & $\mathbf{7 5 \%}$ & $\mathbf{1 0 0 \%}$ \\
\hline No Insulation & 0 & 0 & 0 & 0 \\
\hline R-19 & 6 & 12 & 18 & 24 \\
\hline R-30 & 6 & 13 & 19 & 26 \\
\hline R-38 or Better & 7 & 13 & 20 & 26 \\
\hline Shared Ceilings & 7 & 14 & 20 & 27 \\
\hline
\end{tabular}

\begin{tabular}{|c|c|}
\hline DUCT LEAKAGE & Base:_ Final: \\
\hline CFM per 100 SF & POINTS \\
\hline 80 cfm@25 Pa & 0 \\
\hline $60 \mathrm{cfm} @ 25 \mathrm{~Pa}$ & 4 \\
\hline $40 \mathrm{cfm} @ 25 \mathrm{~Pa}$ & 9 \\
\hline 20 cfm @ 25 Pa & 14 \\
\hline $\begin{array}{l}10 \mathrm{cfm} @ 25 \mathrm{~Pa} \text { or Less or } \\
\text { no ducts (radiant) }\end{array}$ & 17 \\
\hline
\end{tabular}

Figure 1. Section of Boulder, CO's prescriptive pathway checklist used for determining SmartRegs compliance (page 1 of 3 ). 
The checklist includes sections for each major building component such as walls, roofs and foundations, as well as the mechanical systems, lighting and appliances, air leakage, duct leakage and renewables. Each section is subdivided into several ranges of efficiencies. For example, in the Walls section, the inspector can choose from six different efficiency categories, each one corresponding to a range of efficiencies. For instance, the efficiency level R-13 actually applies to any above-grade $2 \times 4$ wall containing cavity insulation including rock wool batts, fiberglass batts, dense packed cellulose or dense packed fiberglass. Technically, these values could range from R-7 to R-15, but they would all be assigned to the same category and receive the same number of points.

To use the checklist, the auditor identifies the percentage of each building component that falls in the corresponding efficiency range and notes the information on the checklist by circling the number of points associated with that component. For example, if $50 \%$ of a home's walls were uninsulated and the other 50\% were insulated to R-13, the Walls section of the checklist would look like Figure 2. This home would gain 10 points from the Walls section.

SmartRegs Prescriptive Pathway
$\begin{aligned} & \text { Need } 100 \text { Total Points + Mandatory } \\
& \text { Water Conservation Measures } \\
& \text { WALS }\end{aligned}$
\begin{tabular}{|lccccc|}
\hline \multicolumn{1}{|c|}{ R-VALUE } & $\mathbf{2 5 \%}$ & $\mathbf{5 n \%}$ & $\mathbf{7 5 \%}$ & $\mathbf{1 0 0 \%}$ \\
\hline No Insulation & 0 & 0 & 0 & 0 \\
\hline $\begin{array}{l}\text { R-3 Continuous (must be at } \\
\text { least R-3) }\end{array}$ & 3 & 6 & 9 & 12 \\
\hline R-5 Continuous & 4 & 8 & 12 & 15 \\
\hline $\begin{array}{l}\text { R-13 or Uninsulated } \\
\text { Basement Wall }\end{array}$ & 5 & 10 & 15 & 20 \\
\hline R-19 or Better & 5 & 11 & 16 & 21 \\
\hline $\begin{array}{l}\text { Shared Wall or Insulated } \\
\text { Basement Wall }\end{array}$ & 6 & 13 & 19 & 26 \\
\hline
\end{tabular}

Figure 2. Example of walls section of SmartRegs checklist for a home where $50 \%$ of the walls are uninsulated and $50 \%$ are insulated to $R-13$. This home would gain 10 points from the walls section.

One of the goals in creating the SmartRegs checklist was to design a tool that would naturally lead property owners to the most cost-effective and highest impact improvements. For example, many more points are awarded for insulating an uninsulated attic to R-38 (26 points) than are given for insulating a slab foundation to R-10 (8 points). Assuming both assemblies are poorly insulated, attic insulation will save much more money, be more cost-effective and is generally easier to install than slab insulation. Points for each improvement were also weighted with respect to carbon emissions reductions: the more points that a home can earn for a measure, the more impact that measure has on the home's overall carbon emissions.

Based on spot audits and energy modeling, CARB evaluated how the prescriptive path and compliance path aligned and whether or not the prescriptive checklist is performing according to the City of Boulder's intent: were property owners being guided to the most cost-effective improvements and those with the biggest environmental benefits? 


\section{Methodology}

\subsection{Research Questions}

It was the intention of this research effort that evaluation of the SmartRegs ordinance would result in valuable information that could be used by other states, counties and municipalities throughout the United States attempting to implement similar programs. This research attempted to answer the following questions:

How does the actual energy savings realized through compliance with this program compare to the predicted savings?

Is the prescriptive checklist methodology an effective alternative to a more comprehensive and costly audit?

What are the biggest barriers to successful energy upgrades and how has the program adapted to these?

\subsection{Technical Approach}

To evaluate the success of Boulder's SmartRegs ordinance and the EnergySmart Advisors service, CARB performed full audits on nine rental properties (12 individual rental units) that had, at a minimum, gone through the initial compliance inspection.

The analysis included on-site diagnostic testing, utility bill analysis (when available), and energy modeling using EnergyGauge and REM/Rate for evaluation of HERS Index, predicted utility bills and energy savings due to retrofits. The units were tested for air leakage and duct leakage (total and leakage to the outside) by CARB staff, using industry approved equipment. All building dimensions, window and door areas, and component efficiency levels were measured and recorded. Solar orientation and shading due to neighboring buildings and trees was noted and accounted for in the energy models. Pressure diagnostics and combustion safety testing using a combustion analyzer were conducted where deemed necessary. With two very experienced auditors - one an engineer from CARB and the other a SmartRegs program developer-full audits took from 2-4 hours to conduct depending on the size, age and complexity of the building. Auditor accuracy and quality of energy improvement work was assessed along with a comparison of the prescriptive and performance compliance paths.

\subsection{Case Studies}

Based on the audits, testing, modeling, and analysis of the prescriptive checklist, CARB compiled case studies for nine rental properties required to comply with the SmartRegs program. Where applicable, these studies, located in the Appendix, include:

- Evaluation of before and after efficiency levels provided by field auditors

- Evaluation of pre-/post- utility bills when provided

- Market barriers to implementation

- Life of measures

- Cost benefit analysis of improvements

- Identification of procedural problems and road blocks to successful program implementation. 


\subsection{Utility Bill Analysis}

To answer the research questions outlined in section 2.1, and to analyze programs like SmartRegs in general, comparisons to actual utility bills are critical. CARB hoped to obtain installed costs and pre-/post- utility bills in order to evaluate cost-effectiveness and compare predicted vs. actual energy savings associated with the energy improvements. Unfortunately, as of December 2011, most units evaluated had not yet implemented the recommended upgrades and for those that had, access to the utility bills was not granted.

\subsection{Evaluation of Training Needs}

Besides the actual audits, CARB evaluated the training needs to ensure successful implementation of the program. Needs that required specific focus included insulating, air sealing and diagnostic testing in existing buildings. Training materials for inspectors and contractors were created for the City of Boulder and were vetted in February 2011. Additional training was recommended based on assessments of common mistakes discovered during CARB's inspections for the case studies.

\section{Results}

Although not an hourly simulation tool, all analysis was performed with REM/Rate for several reasons. First, since several of the properties audited were attached units, BEopt could not be used. Secondly, program creators used REM/Rate to weight and assign the points given to each component. Therefore, using another software to evaluate the program would make no sense. Models were created using EnergyGauge, but the HERS scores generated were so drastically different from those produced using REM/Rate, it was seen as a useless exercise. It made no sense to use REM/Rate to evaluate the points on the checklist and then EnergyGauge to evaluate the savings.

\subsection{Evaluation of Prescriptive Checklist}

The prescriptive audit checklist used by the city of Boulder was custom designed based on Boulder's climate, housing types, and climate action goals. A score of 100 on this checklist indicates a home is in compliance with the City's SmartRegs ordinance and is intended to approximately equate to a HERS Index of 120 . With respect to the HERS Index, a lower score is better than a higher one.

The checklist was created to offer a quicker method of assessing the energy efficiency of the property as compared to a full HERS energy rating (performance path) while maintaining a high level of accuracy. It was also intended that it be used as a guide by auditors and property owners when selecting improvements for the property.

To evaluate the accuracy of the checklist, CARB conducted audits on nine rental properties (12 individual rental units) that had already been assessed for SmartRegs compliance. Of the nine properties audited, four were single-family detached properties and the other five were a combination of duplexes, triplexes and low-rise multi-family buildings. The age of the buildings ranged from early 1900's to the 1960's. Each unit in a property must be scored individually. Of the 12 units audited, only three were in compliance at the time of their initial SmartRegs inspection and, therefore, would not have to make any improvements. At the time of CARB's 
audits, only one building — Case Study \#8 — had been improved since its initial SmartRegs inspection.

Table 3 summarizes the initial SmartRegs prescriptive checklist scores as determined by CARB. Some case studies represent multiple units and, therefore, a range of values is shown. Based on the comprehensive audits, CARB created energy models to determine the HERS Index for comparison to the prescriptive path. The threshold for compliance is 100 points prescriptively, or a HERS Index of 120 or less.

Table 3. Summary of Pre-Retrofit Performance

\begin{tabular}{l|c|c|c|c}
\hline & Year Built & Type & SmartRegs Score(s) & HERS Index \\
\hline Case Study \#1 & $\mathbf{1 9 6 0}$ & Detached & $\mathbf{1 0 0}$ & $\mathbf{1 0 0}$ \\
\hline Case Study \#2 & $\mathbf{1 9 6 0}$ & Detached & 76 & 192 \\
Case Study \#3 & $\mathbf{1 9 6 5}$ & Detached & 62 & 180 \\
\hline Case Study \#4 & $\mathbf{1 9 1 1}$ & Detached & 87 & 155 \\
Case Study \#5 & $\mathbf{1 9 6 6}$ & Multi-Family & $92-104$ & $\mathbf{1 1 2 - 1 2 8}$ \\
Case Study \#6 & $\mathbf{1 9 1 9}$ & Two-family & $59 / 110$ & $181 / 128$ \\
\hline Case Study \#7 & $\mathbf{1 9 5 0}$ & Three-family & 74 & 147 \\
Case Study \#8 & $\mathbf{1 9 5 0}$ & Multi-Family & $48-79$ & $142-173$ \\
Case Study \#9 & $\mathbf{1 9 0 0}$ & Two-family & $85 / 88$ & $150 / 139$ \\
\hline
\end{tabular}

Figure 3 displays the correlation between the HERS Index and the prescriptive checklist score in a scatter plot. This plot shows the inverse relationship between the two scores for the pre-retrofit cases with the trend line running through the target: HERS Index of 120 and a SmartRegs score of 100 .

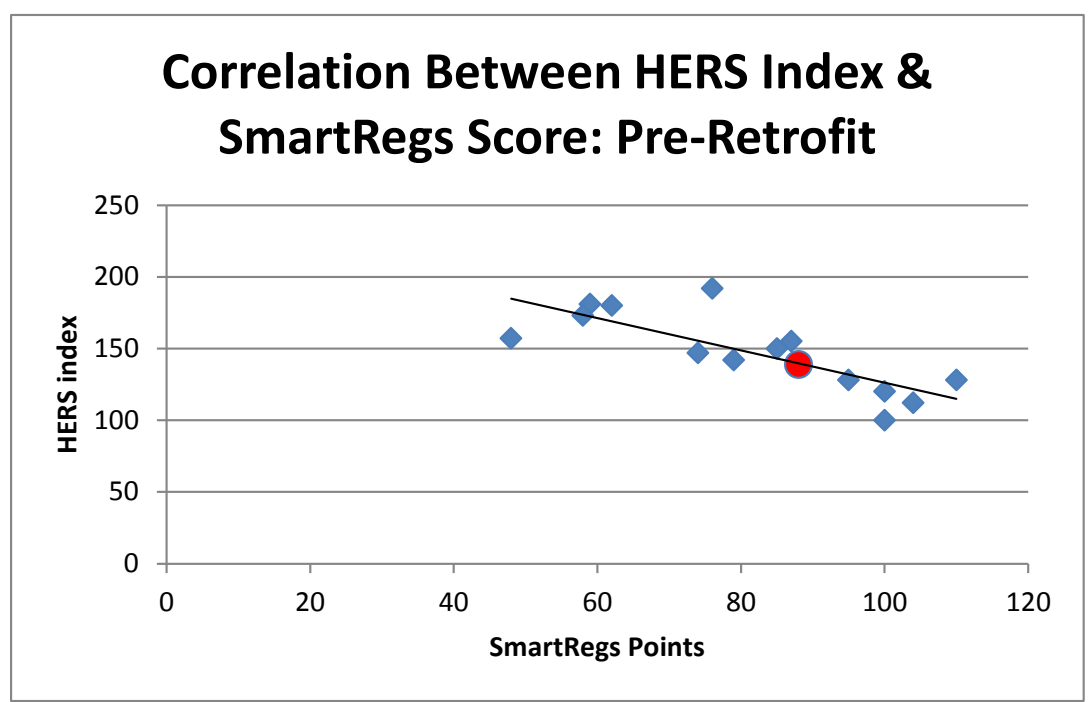

Figure 3. Scatter plot showing the correlation between the HERS Index and the SmartRegs prescriptive checklist score for the pre-retrofit cases.

As can be seen in Table 3, only a few units were able to comply with the SmartRegs ordinance at the time of their initial inspection without having to implement any energy efficient upgrades 
(scores with bold font in Table 4). This is not surprising since most rental property owners have little to no incentive to improve the energy efficiency of their rental units since they won't reap the benefit of lower utility bills.

CARB then analyzed these same properties as if they had been brought into compliance. The prescriptive checklist was used to determine upgrades with the largest impact on the score, keeping in mind construction type, costs and barriers to some improvements such as knob and tube wiring. These improvements were then input into the energy models and the scores were reevaluated. Table 4 shows the predicted prescriptive and performance path results of the same case studies if the recommended retrofits had been implemented. Detailed explanations of the recommended retrofits can be found in the individual case studies in the Appendix.

Table 4. Summary of Post-Retrofit or Recommended Post-Retrofit Performance

\begin{tabular}{l|c|c|c|c}
\hline & Year Built & Type & SmartRegs Score(s) & HERS Index \\
\hline Case Study \#1 & $\mathbf{1 9 6 0}$ & Detached & Passed As-Is & Passed As-Is \\
\hline Case Study \#2 & $\mathbf{1 9 6 0}$ & Detached & 103 & 142 \\
Case Study \#3 & $\mathbf{1 9 6 5}$ & Detached & 100 & 114 \\
Case Study \#4 & $\mathbf{1 9 1 1}$ & Detached & 100 & 144 \\
Case Study \#5 & $\mathbf{1 9 6 6}$ & Multi-Family & $106-118$ & $<106$ \\
Case Study \#6 & $\mathbf{1 9 1 9}$ & Two-family & $104 /$ Passed As-Is & $115 /$ Passed As-Is \\
Case Study \#7 & $\mathbf{1 9 5 0}$ & Three-family & 102 & 105 \\
Case Study \#8 & $\mathbf{1 9 5 0}$ & Multi-Family & $106-117$ & $87-100$ \\
Case Study \#9 & $\mathbf{1 9 0 0}$ & Two-family & $103 / 106$ & $116 / 109$ \\
\hline
\end{tabular}

These results were also plotted to show the post-improvement correlation between the HERS Index and the SmartRegs score (Figure 4). While not as tightly grouped around the trend line as the pre-retrofit scores, correlation is still good with the trend line running very near the target.

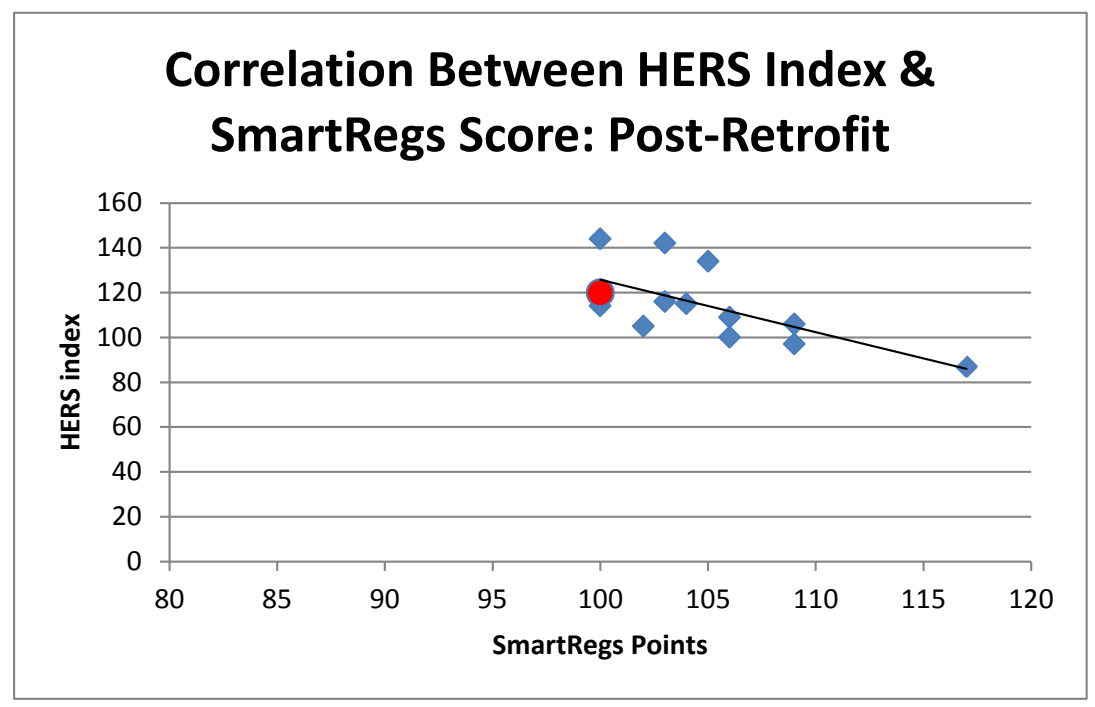

Figure 4. Scatter plot showing the correlation between the HERS Index and the SmartRegs prescriptive checklist score for the actual and recommended post-retrofit cases. 
For most cases, achieving 100 points prescriptively resulted in a HERS Index of less than 120, as was intended by program administrators and designers. There are several possible explanations for why a home may comply with one method and not the other. These are explored in more detail in Section 4.

Predicted utility bill savings, reduction in energy use, and reduction in carbon dioxide generation for each property are summarized in Table 5.

Table 5. Summary of Predicted Savings

\begin{tabular}{l|c|c|c|c|c}
\hline & $\begin{array}{c}\text { Year } \\
\text { Built }\end{array}$ & Housing Type & $\begin{array}{c}\text { Annual } \\
\text { Utility Bill } \\
\text { Savings }\end{array}$ & $\begin{array}{c}\text { Annual } \\
\text { Reduction in } \\
\text { Energy Use }\end{array}$ & $\begin{array}{c}\text { Annual Carbon } \\
\text { Dioxide } \\
\text { Reduction }\end{array}$ \\
\hline Case Study \#1 & $\mathbf{1 9 6 0}$ & Detached & $\mathrm{n} / \mathrm{a}$ & $\mathrm{n} / \mathrm{a}$ & $\mathrm{n} / \mathrm{a}$ \\
\hline Case Study \#2 & $\mathbf{1 9 6 0}$ & Detached & $\$ 464$ & $24 \%$ & $22 \%$ \\
\hline Case Study \#3 & $\mathbf{1 9 6 5}$ & Detached & $\$ 464$ & $36 \%$ & $29 \%$ \\
\hline Case Study \#4 & $\mathbf{1 9 1 1}$ & Detached & $\$ 138$ & $7 \%$ & $6 \%$ \\
\hline Case Study \#5 & $\mathbf{1 9 6 6}$ & Multi-Family & $\$ 100$ & $24 \%$ & $17 \%$ \\
\hline Case Study \#6 & $\mathbf{1 9 1 9}$ & Two-family & $\$ 589$ & $38 \%$ & $34 \%$ \\
\hline Case Study \#7 & $\mathbf{1 9 5 0}$ & Three-family & $\$ 231$ & $23 \%$ & $22 \%$ \\
\hline Case Study \#8 & $\mathbf{1 9 5 0}$ & Multi-Family & $\$ 230-\$ 450$ & $32-52 \%$ & $27-46 \%$ \\
\hline Case Study \#9 & $\mathbf{1 9 0 0}$ & Two-family & $\$ 170$ & $21 \%$ & $20 \%$ \\
\hline
\end{tabular}

For the properties where no previous improvements had been made (CS \#2, \#3, \#5, \#6, \#7, \#8), predicted energy use reductions ranged from $23 \%$ to $52 \%$ per unit.

\subsection{Utility Bill Analysis}

Case Study \#8 was the only property for which CARB was able to obtain utility bills, and these were only available for the pre-retrofit case. While this data set is far too small to be statistically significant, it is used here to help illustrate the issues associated with trying to predict energy use, especially in older, inefficient homes.

This multi-family property was constructed in the 1950's and consists of 37 rental units: $182-$ bedroom units, 18 1-bedroom units and 13 -bedroom unit. The complex was constructed with minimal attic insulation, no wall insulation, and single pane windows. Heating is provided by ductless in-unit natural gas heaters, and hot water is provided by six centrally located gas storage water heaters. No cooling or mechanical ventilation is provided, although some tenants install window air conditioners on their own. Actual annual bills per unit range from $\$ 200-\$ 600$ for electricity and \$250-\$550 for natural gas, with almost \$210 annually in just monthly service charges.

Compliance with the SmartRegs prescriptive checklist was evaluated, and it was determined that the worst-case unit (first floor corner) would need at least 52 points to become compliant. The package of improvements selected to bring all units into compliance included: blowing 13" of cellulose into the attic (R-50); new double-pane, low-e windows with U-values of 0.3; adding blown cellulose to the walls (R-13); compact fluorescent lamp (CFL) replacements in 100\% of lights; and new ENERGY STAR ${ }^{\circledR}$-qualified refrigerators. With the extra insulation and new 
windows, they were also able to collect points due to reduced air leakage, bringing the postretrofit prescriptive score for the worst case unit to 106. Had the Performance Path been selected, modeling results also show compliance post-retrofit, with a HERS Index of 97.

As mentioned above, only pre-retrofit bills were available for this property. Figure 5 and Figure 6 show the actual monthly electric and gas use for 10 units in this complex. Data from these bills (Figure 5) for the 1-bedroom units show spikes in electricity usage in both winter and summer, with units on the second floor seeing the greatest spikes.

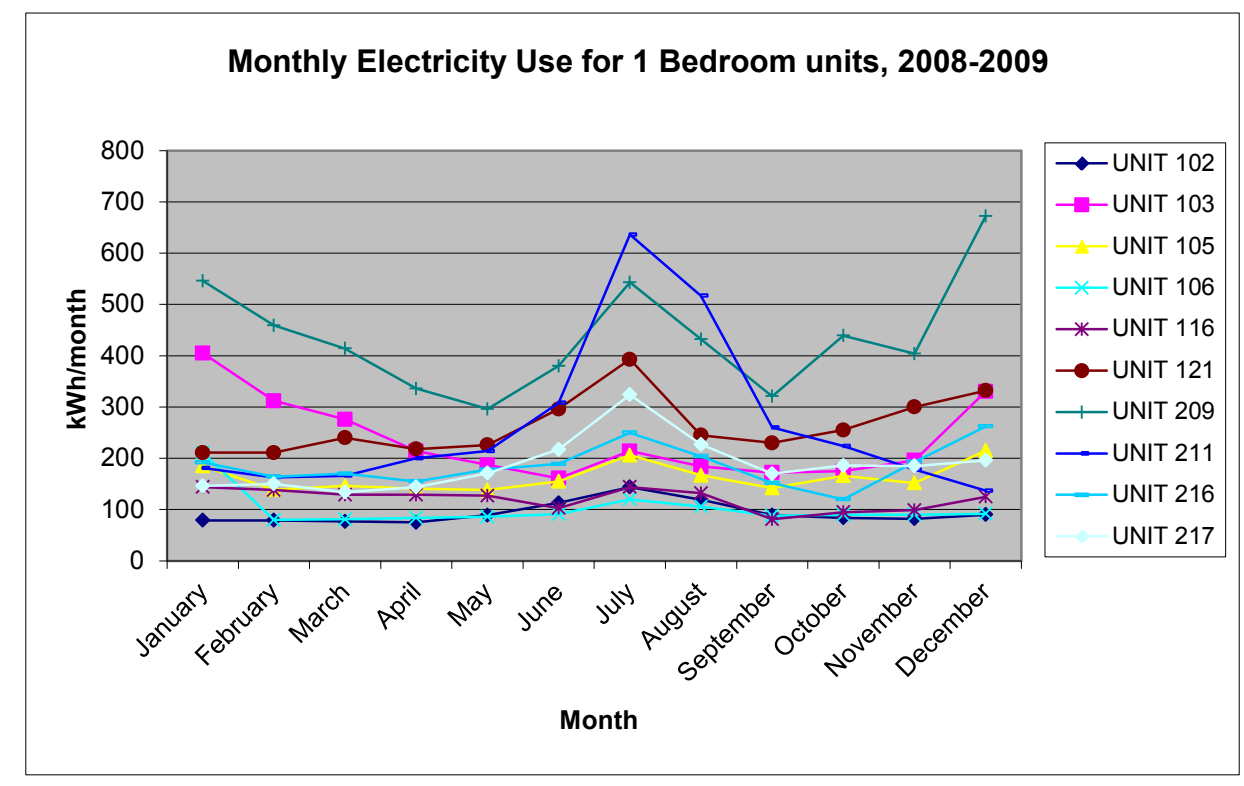

Figure 5. Monthly electric utility use (kWh) for a sample of 1-bedroom units for the property in case study \#8.

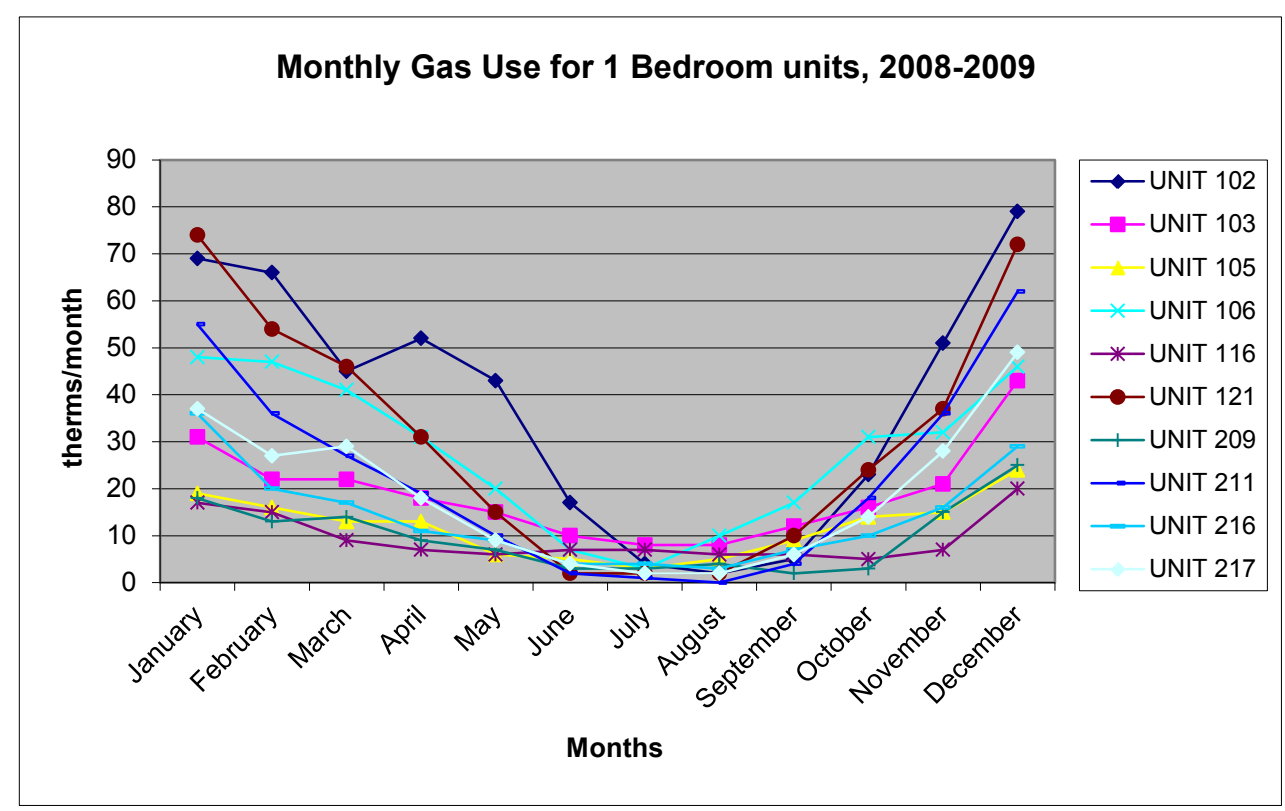

Figure 6. Monthly natural gas use (therms) for a sample of 1-bedroom units for the property in case study \#8. 
Since a full year of post-retrofit bills was not available for analysis, pre-retrofit bills were analyzed and compared to modeling predictions. Figure 7 and Figure 8 compare actual usage per square foot of conditioned space for three different units to predicted pre and post-retrofit usage. As shown in Figure 7, the model sometimes underpredicted and sometimes overpredicted electricity consumption. Underpredictions were mostly related to units with surges in electricity usage in the summer, most likely from using window air conditioners (usually units on the second floor); overpredictions could result from reductions in occupancy as is typical of student housing.

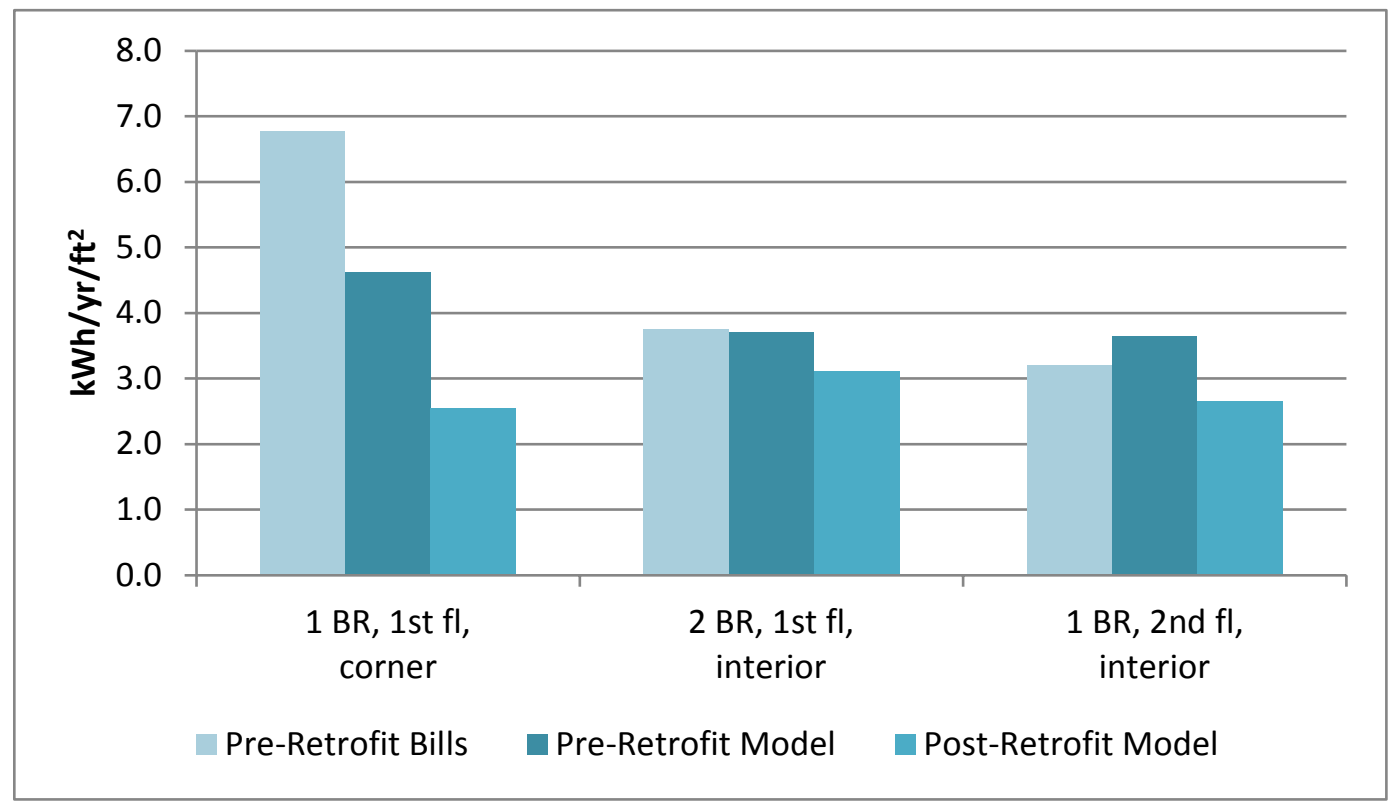

Figure 7. Predicted annual electricity use $\left(\mathrm{kWh} / \mathrm{ft}^{2}\right)$ for the models types with available pre-retrofit utility bills.

Unlike the predictions for electricity consumption, the models consistently and significantly overpredicted gas consumption (Figure 8). It is suspected that the units are not being directly billed for the natural gas for the central water heaters ( $\sim 150$ therms per unit per year), but this does not explain the entire discrepancy. As stated in a report from NREL by Polly et. al., multiple studies have shown that modeling software tends to overpredict heating energy use in older, inefficient homes (2011). This study definitely supports those observations. 


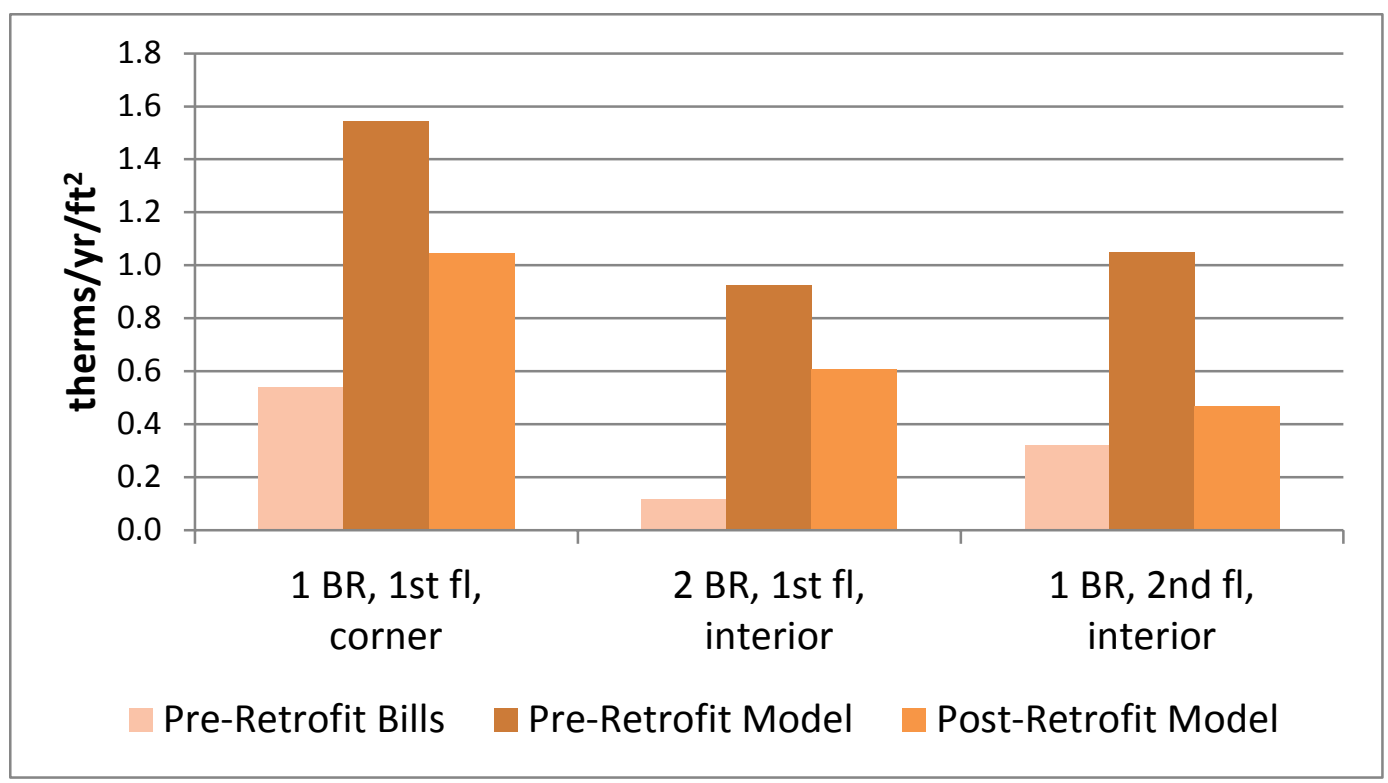

Figure 8. Predicted annual natural gas use $\left(\right.$ therms $/ \mathrm{ft}^{2}$ ) for the models types with available preretrofit utility bills.

Beyond what was described above, energy models make assumptions on things like weather, number of occupants in a home, and components in the home affected by occupant behavior such as thermostat settings, lighting, and appliance use.. This can lead to a discrepancy between actual bills and savings estimated by the model. For example, if the weather was uncharacteristically warm for this location, predicted heating energy use would be expected to be higher than actual energy use. Also, energy-conscious occupants could be expected to use less energy than predicted in the model. This in turn affects savings. If actual pre-retrofit energy usage is less than predicted, as was the case for the units analyzed, actual savings may be lower than predicted.

With these issues in mind, further research needs to be conducted on the accuracy of modeling software when predicting energy use in existing homes. For community-scale retrofit projects like this one, it would be impossible to model each home based on actual occupant behavior. Assumptions will still have to be made with respect to thermostat settings, lighting and appliance use, and weather variations, but perhaps those assumptions currently being used need to be adjusted.

\subsection{Training Needs}

Part of CARB's involvement with Boulder's SmartRegs program was to evaluate the training needs of the auditors and contractors. Therefore, during these audits, CARB compared its audit results to that of the SmartRegs inspector. SmartRegs scores were recalculated based on CARB's findings and compared to the original inspection. Table 6 summarizes the scores calculated during the original SmartRegs inspections, the score from CARB's audit, and the reasons for the differences, if any.

In general, auditor knowledge ranged from very experienced and knowledgeable to a few who could use a little more training and experience, but this is not uncommon in the auditing and rating industry. 
Table 6. SmartRegs Prescriptive Checklist Scores: SmartRegs Inspector vs. CARB Audit Results

\begin{tabular}{|c|c|c|c|}
\hline & $\begin{array}{l}\text { SmartRegs } \\
\text { Inspector }\end{array}$ & $\begin{array}{l}\text { CARB } \\
\text { Audit }\end{array}$ & Reason for Difference \\
\hline Case Study \#1 & 100 & same & $\mathrm{n} / \mathrm{a}$ \\
\hline Case Study \#2 & 89 & 76 & Furnace efficiency \\
\hline Case Study \#3 & 64 & 62 & $\begin{array}{l}\text { Slight volume miscalculation affecting } \\
\text { ACH@50 results }\end{array}$ \\
\hline Case Study \#4 & 75 & 87 & $\begin{array}{l}\text { DHW efficiency too high, square footage of } \\
\text { basement too low, refrigerator efficiency too } \\
\text { high, no credit given for efficient } \mathrm{A} / \mathrm{C} \text {, duct } \\
\text { testing performed by CARB not auditor }\end{array}$ \\
\hline Case Study \#5 & $92-104$ & same & $\mathrm{n} / \mathrm{a}$ \\
\hline Case Study \#6 & $40 / 93$ & $59 / 110$ & $\begin{array}{c}\text { CARB performed duct testing, Auditor hadn't; } \\
\text { otherwise no differences }\end{array}$ \\
\hline Case Study \#7 & 88 & 70 & $\begin{array}{l}\text { Boiler efficiency assumption too high, wall } \\
\text { insulation missed, Occupant changes - window } \\
\text { A/C, incandescent lights }\end{array}$ \\
\hline Case Study \#8 & $48-79$ & Same & $\mathrm{n} / \mathrm{a}$ \\
\hline Case Study \#9 & $80 / 88$ & $85 /$ same & Small section of wall insulation missed \\
\hline
\end{tabular}

Several of the audits resulted in very similar if not identical scores. A few of the differences were the result of duct leakage testing. The SmartRegs program does not require duct leakage testing, but if it is performed, there are substantial points that can be gained if the ducts prove to be below certain leakiness levels. In CS \#4 and \#6, points were awarded for the results of duct leakage testing performed by CARB after the initial inspection.

Areas identified as needing further training included identification of mechanical system type and efficiency for heating, cooling and domestic hot water (DHW), and more thorough inspection of wall and ceiling insulation in existing homes.

\section{Discussion}

Although there is good agreement between the prescriptive and performance paths, there are circumstances when a home may pass one and not the other. There could be several reasons why the HERS Index is higher than 120, but according to the SmartRegs prescriptive checklist, the unit is in compliance. Discrepancies in the scoring could be attributed to several different factors. For example, modeling issues include:

- Smaller homes tend to get higher HERS indices because the surface-area-to-volume ratios are higher than for larger homes.

- The higher the window-to-wall area ratio the more heat loss from the home. SmartRegs doesn't measure areas, just efficiencies of the components.

- Orientation is not considered in SmartRegs, but will affect a HERS Index due to its impact on solar gain. 
- SmartRegs uses steps in efficiency levels and associates points with each step vs. using the actual efficiency as is done in a HERS model.

- Definitions of conditioned vs. unconditioned basements are slightly different between the two methods.

There are also programmatic reasons that these two paths can result in different answers. When the program first began, ceilings with any level of insulation below R-19 were getting full credit for being insulated to R-19. When modeled, the actual insulation level would be entered, thus resulting in a worse HERS Index than a prescriptive checklist score. Program administrators have since corrected this, and homes with less than R-19 insulation receive no points in that category.

Also, storm windows on historic homes receive more than twice the points as windows with a similar efficiency on a non-historic home. This is to ease some of the burden on the owners, because improving historic properties is usually much more difficult and costly. Again, the actual U-value of the window would be input into an energy model, potentially resulting in a worse HERS Index than the prescriptive checklist score would indicate.

Another program decision was to not give any credit to crawlspace ceiling insulation on the SmartRegs prescriptive checklist if the mechanical equipment and/or any of the ductwork are located in that space. The City's reasoning behind this is that one of the goals of the SmartRegs program is to promote the most cost-effective, energy efficient improvements while improving living conditions - comfort, safety, indoor air quality etc. - for the renters. The city of Boulder feels that converting unconditioned crawlspaces to conditioned, air-sealed, warm, dry spaces is one of the measures that will help them achieve these goals. Unlike the previously mentioned exceptions, this would result in a worse prescriptive score than performance index because the R-11 would be included in the energy model.

Finally, since a reduction in greenhouse gas emissions is one of Boulder's major goals, reductions in electricity consumption have been assigned greater weight in the checklist. This is particularly evident with respect to the number of points awarded for photovoltaics $(\mathrm{PV}): 1 \mathrm{~kW}$ gains 44 points on the prescriptive checklist. Qualifying installations include power purchase agreements, solar leases or verified subscriptions in the Community Solar Garden program. A property owner must first score a minimum of 70 points on the prescriptive checklist before this category can be applied, but currently, the program only looks at rated output of the system rather than installed performance.

CARB's building science-based recommendations generally aligned well with the upgrades assigned higher point values except for PV, (although understandably a good approach to reducing greenhouse gas emissions), which is awarded a disproportionate number of points on the checklist. This is supported by the HERS Index comparison for one of the case studies in which the first package - insulating the ceiling to R-30, replacing the DHW with a tankless unit, installing storm windows, installing an ENERGY STAR refrigerator, insulating the basement and air sealing — results in a HERS Index of 115; but the second upgrade package - just insulating the ceiling to R-30 and installing $1 \mathrm{~kW}$ of PV-only achieves a HERS Index of 162 but passes using the prescriptive path. 


\section{Conclusions}

Comprehensive case studies were used to evaluate Boulder, Colorado's SmartRegs program. Comparing prescriptive results to performance path results showed good agreement, which will enable more property owners to select the less expensive prescriptive route and know they will get similar results. The time required to conduct a prescriptive inspection is less than half of that required to perform a full audit and produce a HERS Index.

From the evaluation conducted to date, it appears that the prescriptive checklist is an effective alternative to a more comprehensive, costly audit. The checklist was developed to guide owners to make the decisions that will have the greatest impact on reductions in energy use and greenhouse gas emissions, and appears to be successful in doing that.

With similar programs being developed across the country and the current administration's focus on large-scale retrofit activities, knowledge gained from this project could significantly impact the decisions of others. Evaluating, improving, and promoting retrofit programs like Boulder's SmartRegs ordinance could lead to energy efficiency improvements for millions of residential rental units across the United States and result in lower gross rents for much of the country's rental population.

Of the approximately 35 million rental units in the United States, more than 24 million were built before 1980 and consequently, to those efficiency levels. These statistics suggest an enormous opportunity for energy reduction in rental units in this country. Unfortunately, without access to utility bill data for pre and post-retrofit cases, CARB cannot make an accurate estimate as to what those savings will be. As this is a common problem in studies like this, obtaining access to utility bills for community-scale retrofit programs should be made a priority by researchers and policy makers alike.

Based on the small number of utility bills that were obtained, this study supports what others have found: energy modeling software overpredicts energy use in older, inefficient homes. Further research into the assumptions assigned to occupant behavior and basic modeling parameters is needed.

Without real world data to analyze the models, predictions for actual MMBtu reductions are difficult. Even so, this study suggests that Boulder's housing stock dated from the 1960's and earlier should realize savings of about $23 \%$ to $52 \%$ annually when bringing the homes into compliance with the SmartRegs requirements, assuming no previous upgrades have been performed. This is in line with the $30 \%-50 \%$ reduction goals of the Building America program.

CARB also used these case studies to inform the City of Boulder of suggestions and owner feedback to improve their program offering. Interviews were conducted with either the property owner or the manager regarding their experiences with the SmartRegs ordinance. While there was some general resistance to the idea of a city-mandated program like this, participants repeatedly remarked that compliance was not as difficult as originally anticipated.

The majority of participants also expressed that the free energy advisor service (offered under the EnergySmart program) was instrumental to the successful implementation of Boulder's 
ordinance. Services offered by the advisors include: assistance in determining where individual properties stand in relation to SmartRegs compliance; recommendations for the best method of compliance for each individual rental property; direct installation of energy efficiency measures; help in scheduling contractors for any efficiency improvements that needed to be made; and identifying rebates and incentives that are available for the work.

To properly assess the impacts of a retrofit program, long-term monitoring and evaluation is necessary. CARB initially proposed a 3-year evaluation of the SmartRegs program such that upgrade costs and post-retrofit utility bills could be analyzed to determine actual energy savings and cost-effectiveness of a community scale retrofit program like Boulder's. Although this was not accomplished in the first year of the evaluation, the evaluation of the program itself is positive and is an example that can be replicated in other cities.

A few basic recommendations include:

Follow RESNET's guidelines for assigning age-based efficiencies for older unlabeled equipment ${ }^{4}$.

Create mandatory requirements for the cost-effective low-hanging fruit such as CFLs.

Remove the point category for not installing cooling or only allow credit if the home has a combination of certain features such as adequate ceiling and wall insulation and good windows, which would reduce the cooling load and the likelihood that occupants will install window units.

Award points for PV based on anticipated generation, rather than installed capacity.

\footnotetext{
${ }^{4}$ http://www.resnet.us/standards/RESNET_Mortgage_Industry_National_HERS_Standards.pdf
} 


\section{Acknowledgments}

CARB partnered with both the City of Boulder's Community Planning and Sustainability department and the County of Boulder's County Commissioner's Office, and with the central program administrator, Populus, LLC. 


\section{Appendix A SmartRegs Prescriptive Checklist}




\section{SmartRegs Prescriptive Pathway Checklist}

Need 100 Total Points + Mandatory Water Conservation Measures

\section{This form is to be used by City of Boulder Class G licensed inspectors.}

Instructions:

1. Circle the applicable point selection in each category

2. Fill in the Base and Final Points in each category

3. Total the points in the table below

4. Provide a Class $\mathrm{G}$ inspector license number and signature

5. Submit the form with the preceding SmartRegs Energy Efficiency Application pages

Unit Address and Number:

Enter total points in the space below

\begin{tabular}{|l|l|}
\hline Total Base Points & \\
\hline Total Final Points & \\
\hline Total Water Conservation Points & \\
\hline
\end{tabular}

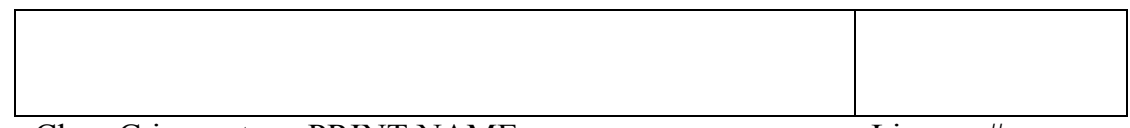

Class G inspector - PRINT NAME

License \#

Class G Inspector Signature

\section{Mandatory Water Conservation}

Must earn two points regardless of whether Performance or Prescriptive SmartRegs Pathway is chosen. Points earned in this category do not count towards Prescriptive 100 point requirement.

\begin{tabular}{|c|c|}
\hline Water Conservation Measure & Points \\
\hline Low flow showerhead* & 1 \\
\hline Low flow lavatory faucets* & 1 \\
\hline Self-closing faucet valves ${ }^{* *}$ & 1 \\
\hline High-efficiency or dual-flush toilet ${ }^{\star}$ & 2 \\
\hline ENERGY STAR washing machine & 2 \\
\hline ENERGY STAR dishwasher & 2 \\
\hline
\end{tabular}

${ }^{*}$ Points awarded based on average of all fixtures in unit -

**Points awarded if all faucets are equipped with self-closing valves. -

Please refer to the SmartRegs Guidebook for further clarification. - 
WALLS

\begin{tabular}{|l|c|c|c|c|}
\hline \multicolumn{1}{|c|}{ R VALUE } & $\mathbf{2 5 \%}$ & $\mathbf{5 0 \%}$ & $\mathbf{7 5 \%}$ & $\mathbf{1 0 0 \%}$ \\
\hline No Insulation & 0 & 0 & 0 & 0 \\
\hline$\geq$ R-3 Continuous & 3 & 6 & 9 & 12 \\
\hline R-5 Continuous & 4 & 8 & 12 & 15 \\
\hline R-13 & 5 & 10 & 15 & 20 \\
\hline Uninsulated Basement Wall & 5 & 10 & 15 & 20 \\
\hline$\geq$ R-19 & 5 & 11 & 16 & 21 \\
\hline Insulated Basement Wall & 6 & 13 & 19 & 26 \\
\hline Shared Wall & 6 & 13 & 19 & 26 \\
\hline
\end{tabular}

WINDOWS/FENESTRATION Base:

Final:

\begin{tabular}{|l|c|c|c|c|}
\hline \multicolumn{1}{|c|}{ U FACTOR } & $\mathbf{2 5 \%}$ & $\mathbf{5 0 \%}$ & $\mathbf{7 5 \%}$ & $\mathbf{1 0 0 \%}$ \\
\hline $\begin{array}{l}\text { Single Metal } \\
\text { (1.2 U-Factor) }\end{array}$ & 0 & 0 & 0 & 0 \\
\hline $\begin{array}{l}\text { Single Non-Metal } \\
\text { (.95 U-Factor) }\end{array}$ & 0 & 1 & 1 & 2 \\
\hline $\begin{array}{l}\text { Double Metal } \\
\text { (.80 U-Factor) }\end{array}$ & 1 & 2 & 3 & 4 \\
\hline $\begin{array}{l}\text { Double Non-Metal } \\
\text { (.55 U-Factor) }\end{array}$ & 2 & 3 & 5 & 6 \\
\hline 0.35 U-Factor & 3 & 7 & 10 & 13 \\
\hline 0.30 U-Factor & 3 & 7 & 10 & 14 \\
\hline$\leq 0.25$ U-Factor & 4 & 7 & 11 & 14 \\
\hline
\end{tabular}

\section{INFILTRATION}

Base:

Final:

\begin{tabular}{|l|c|}
\hline $\mathrm{ACH}_{\mathrm{n}}$ & POINTS \\
\hline$\leq 1.20 \mathrm{ACH}_{\mathrm{n}}$ & 2 \\
\hline $0.75 \mathrm{ACH}_{\mathrm{n}}$ & 4 \\
\hline $0.50 \mathrm{ACH}_{\mathrm{n}}$ & 6 \\
\hline$\leq 0.35 \mathrm{ACH}_{\mathrm{n}}$ (ventilate per ASHRAE 62.2) & 7 \\
\hline \multicolumn{2}{|c|}{ TEST STATS: } \\
\hline $\mathrm{ACH}_{\mathrm{i}:}$ & Volume: \\
\hline $\mathrm{CFM}_{0}:$ & n-Factor: \\
\hline
\end{tabular}

CEILINGS

\begin{tabular}{|l|c|c|c|c|}
\hline \multicolumn{1}{|c|}{ R VALUE } & $\mathbf{2 5 \%}$ & $\mathbf{5 0 \%}$ & $\mathbf{7 5 \%}$ & $\mathbf{1 0 0 \%}$ \\
\hline No Insulation & 0 & 0 & 0 & 0 \\
\hline R-19 & 6 & 12 & 18 & 24 \\
\hline R-30 & 6 & 13 & 19 & 26 \\
\hline$\geq$ R-38 & 7 & 13 & 20 & 26 \\
\hline Shared Ceilings & 7 & 14 & 20 & 27 \\
\hline
\end{tabular}

FLOORS / FOUNDATIONS Base:__ Final:

\begin{tabular}{|l|c|c|c|c|}
\hline \multicolumn{5}{|c|}{ SLAB ON GRADE } \\
\hline TYPE & $\mathbf{2 5 \%}$ & $\mathbf{5 0 \%}$ & $\mathbf{7 5 \%}$ & $\mathbf{1 0 0 \%}$ \\
\hline Slab Edge: R-0 & 2 & 3 & 5 & 6 \\
\hline Slab Edge: $>$ R-5 & 2 & 4 & 5 & 7 \\
\hline Slab Edge: $>$ R-10 & 2 & 4 & 6 & 8 \\
\hline $\begin{array}{l}\text { Slab Edge: }>\text { R-10 AND } \\
\text { Under Slab: }>\text { R-10 }\end{array}$ & 3 & 6 & 8 & 11 \\
\hline
\end{tabular}

BELOW GRADE SLAB (Basement Slab)

\begin{tabular}{|l|l|l|l|l}
\hline Basement Slab & 2 & 4 & 6 & 8 \\
\hline
\end{tabular}

\begin{tabular}{|l|c|c|c|c|}
\hline \multicolumn{5}{|c|}{ FOUNDATION WALLS (Crawlspace) } \\
\hline $\mathrm{R}-0$ & 0 & 0 & 0 & 0 \\
\hline $\mathrm{R}-2$ & 2 & 3 & 5 & 6 \\
\hline $\mathrm{R}-11$ & 2 & 4 & 6 & 8 \\
\hline $\mathrm{R}-19$ & 2 & 5 & 7 & 9 \\
\hline
\end{tabular}

\section{FRAMED FLOORS \\ (Only Available if No Ducts or HVAC Equipment are Located in Unconditioned Space Below Floor)}

Framed Floor: R-0

Framed Floor: R-13

Framed Floor: R-25

Framed Floor: >R-38

Shared Floor

\begin{tabular}{|c|c|c|c|}
\hline 0 & 0 & 0 & 0 \\
\hline 3 & 5 & 8 & 11 \\
\hline 3 & 6 & 9 & 12 \\
\hline 4 & 7 & 11 & 14 \\
\hline 4 & 8 & 11 & 15 \\
\hline
\end{tabular}

DUCT LEAKAGE

Base:

\begin{tabular}{|l|c|}
\hline CFM per 100 SF & POINTS \\
\hline $80 \mathrm{cfm} @ 25 \mathrm{~Pa}$ & 0 \\
\hline $60 \mathrm{cfm} @ 25 \mathrm{~Pa}$ & 4 \\
\hline $40 \mathrm{cfm} @ 25 \mathrm{~Pa}$ & 9 \\
\hline $20 \mathrm{cfm} @ 25 \mathrm{~Pa}$ & 14 \\
\hline$\leq 10 \mathrm{cfm} @ 25 \mathrm{~Pa}$ & 17 \\
\hline No Ducts & 17 \\
\hline
\end{tabular}

DISTRIBUTION SYSTEM Base:__Final:

\begin{tabular}{|l|c|c|c|c|}
\hline LOCATION / INSULATION & $\mathbf{2 5 \%}$ & $\mathbf{5 0 \%}$ & $\mathbf{7 5 \%}$ & $\mathbf{1 0 0 \%}$ \\
\hline $\begin{array}{l}\text { Uninsulated Pipes/Ducts } \\
\text { (In Unconditioned Space) }\end{array}$ & 0 & 0 & 0 & 0 \\
\hline $\begin{array}{l}\text { Pipes/Ducts Insulated (R-4) } \\
\text { (In Unconditioned Space) }\end{array}$ & 1 & 3 & 4 & 6 \\
\hline $\begin{array}{l}\text { Pipes / Ducts Within } \\
\text { Conditioned Space }\end{array}$ & 2 & 3 & 5 & 7 \\
\hline
\end{tabular}

*Historically designated properties and properties older than 50 years with wooden window frames that rehabilitate and install storm panels will receive credit at the $0.35 \mathrm{U}$-Value level. 
HEATING

\begin{tabular}{|l|c|}
\hline SPECIFICATION & POINTS \\
\hline Electric, Oil, or ASHP & 0 \\
\hline Gas 65\% AFUE & 0 \\
\hline Gas $80 \%$ AFUE & 13 \\
\hline Gas $90 \%$ AFUE & 17 \\
\hline Gas $96 \%$ AFUE & 19 \\
\hline GSHP (COP 3.3) & 29 \\
\hline GSHP (COP 4.1) & 38 \\
\hline GSHP (COP 4.8) & 43 \\
\hline
\end{tabular}

COOLING

Base:

\begin{tabular}{|l|c|}
\hline SPECIFICATION & POINTS \\
\hline 10 SEER or worse & 0 \\
\hline 13 SEER & 4 \\
\hline 15 SEER & 6 \\
\hline Direct Evaporative Cooler & 6 \\
\hline No Cooling & 6 \\
\hline 17 SEER & 7 \\
\hline 19 SEER & 8 \\
\hline Indirect Evaporative Cooler & 8 \\
\hline GSHP $(\geq$ EER 13.6) & 4 \\
\hline
\end{tabular}

LIGHTING

\begin{tabular}{|l|c|}
\hline $\begin{array}{l}\text { HIGH EFFICACY } \\
\text { LIGHTING (solar tubes/light } \\
\text { tunnels counted as light fixtures) }\end{array}$ & POINTS \\
\hline $0 \%$ & 0 \\
\hline $25 \%$ & 2 \\
\hline $50 \%$ & 4 \\
\hline $75 \%$ & 6 \\
\hline $100 \%$ & 7 \\
\hline
\end{tabular}

HOT WATER

Base: Final:

\begin{tabular}{|l|c|}
\hline SPECIFICATION & POINTS \\
\hline Electric, Oil or Heat Pump & 0 \\
\hline Gas 0.56 EF & 0 \\
\hline Gas 0.60 EF & 1 \\
\hline Gas 0.64 EF & 2 \\
\hline Gas >0.82 EF & 6 \\
\hline Gas Boiler Side Arm (65\% AFUE Boiler) & 0 \\
\hline Gas Boiler Side Arm (80\% AFUE Boiler) & 3 \\
\hline Gas Boiler Side Arm (95\% AFUE Boiler) & 5 \\
\hline
\end{tabular}

WHOLE HOUSE FANS SPECIFICATION

Whole House Fan

REFRIGERATION
\begin{tabular}{|l|c|}
\hline SPECIFICATION & Base: \\
\hline $750 \mathrm{kWh} /$ year & POInal: \\
\hline $650 \mathrm{kWh} /$ year & 0 \\
\hline $450 \mathrm{kWh} /$ year & 2 \\
\hline$\leq 350 \mathrm{kWh} /$ year & 3 \\
\hline
\end{tabular}

SOLAR THERMAL SPECIFICATION

Points per $20 \mathrm{sq} \mathrm{ft}$ of collector surface area

PHOTOVOLTAICS*

\begin{tabular}{|l|}
\hline ARRAY RATED OUTPUT \\
\hline Points per kW \\
\hline
\end{tabular}

OCCUPANT

Base: Final:

\section{POINTS} 8

\section{MEASURE}

Sub-Metering: Real Time Energy Monitoring Device

Programmable Thermostat

Provide Operation / Training Manual

Tenant Attends Energy Conservation Class

OTHER

MEASURE

Heat Pump Desuperheater

Electronically Commutated Motor ("ECM")

Passive Solar Design

Innovative Practice

Technically Impractical:

Carbon Offsets
Base:

Base:

POINTS
44

Final:

\section{POINTS}

2 
\begin{tabular}{l|l} 
u.s. DEPARTMEnt of & Energy Efficiency \& \\
ENERCY & Renewable Energy
\end{tabular}

\section{Appendix B Case Studies}




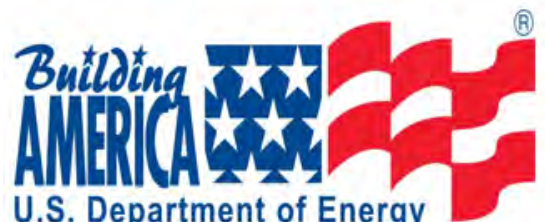 Cold Climate Region: Case Study \#1
City of Boulder, SmartRegs Ordinance
Single Family Detached, 1960's Vintage}

\section{Boulder, CO}

Program

Location:

Building Type:

Building Size:

Foundation:

Configuration:

SWA Contact:

This single family detached rental property is located in Boulder, CO, in an area well known for its small, ranch style homes very often used as rental property. Typical of homes built in the 1950's and 1960's in Boulder, it is a 3 bedroom, 1 bathroom single-story house just under $1,000 \mathrm{ft}^{2}$ built over a crawlspace foundation.

The property owner was one of several people to sign up early for the SmartRegs audit to ensure that his rental property complies with the City of Boulder's new requirements that all rental properties meet a certain energy efficiency level by 2019 .

As is evident from the owner's answers to several interview questions (see Property Owner's Story), he is very committed to energy conservation and wanted to know as early as possible if his properties complied with the new regulations. If not, this would give him time to plan for the needed upgrades.

Because of the owner's commitment to energy conservation, he had already made several energy improvements to the property before the new regulations were put in place. The attic had been air sealed and insulated to approximately R-38. The exterior walls $(2 \times 4)$ were dense-packed with cellulose insulation, and all windows were upgraded to double-pane, low-e, vinyl units with U-values of 0.30 . The crawlspace ceiling had been insulated and air sealed from the house and the existing ductwork located in the crawl had been insulated.

Air leakage and pressure testing confirmed that both the attic and the crawlspace were well isolated from the main living area. Based on the blower door result of 986 cfm@50 pascals, the estimated infiltration rate of this home is approximately 0.44 air changes per hour under natural conditions $(\mathrm{ACHn})$ or 8 ACH@50 pascals.

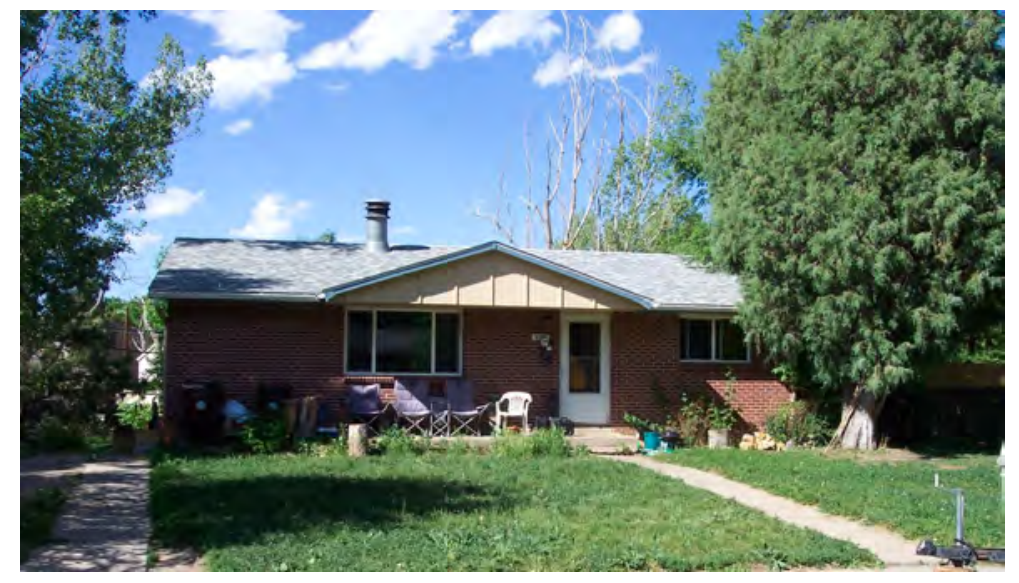

This rental property passed Boulder's SmartRegs requirements upon initial inspection.

\section{Energy Efficient Features}

Attic: Blown-in cellulose insulation-R38

Walls: Dense-packed cellulose-R-13

Windows: $\quad$ Low-e, double-pane, vinyl-U-0.30

Foundation: $\quad$ Fiberglass batts-R-11 in crawlspace ceiling

Heating: $\quad$ Forced air, natural gas, conditioned space80 AFUE

$\begin{array}{ll}\text { Cooling: } & \text { None } \\ \text { Ductwork: } & \text { Insulated w/ R-4 fiberglass batts, uncondi- }\end{array}$

tioned space

Hot Water: $\quad$ Atmospheric, natural gas, conditioned space-0.59 EF

Air Leakage: $\quad 8 \mathrm{ACH}$ @50 pascals, $0.44 \mathrm{ACHn}$

\section{Additional SmartRegs Features}

Water-saver faucets and showerheads

\section{SmartRegs Checklist Score*: 100 points}

(The final score must be $\geq 100$ )

HERS Index: 100

*100 points on the SmartRegs checklist was intended to approximately equate to a HERS index of 120 . www.swinter.com

50 Washington St. 6th FI, Norwalk, CT 06854 307 7th Ave. Ste. 1701, New York, NY 10001

1112 16th St., NW Ste. 240, Washington, DC 20036 tel 203-857-0200 fax 203-852-0741 tel 212-564-5800 fax 212-741-8673 tel 202-628-6100 fax 202-393-5043 


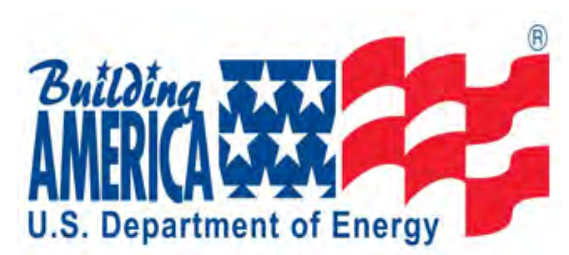

Boulder, CO

The owner of this property opted to use the prescriptive method of compliance and have the auditor fill out a checklist rather than perform energy modeling to determine if the property was in compliance. Based on the auditors assessment, this home scored 100 points on the SmartRegs checklist and is, therefore, in compliance with the program (confirmed by SWA during a follow up audit) The owner is not required to make any further energy related improvements at this time.

When creating the prescriptive checklist, the authors set out to create a threshold that would apply to all homes. After extensive analysis, it was determined that 100 points on the checklist should approximately equate to a HERS index of 120 points, more or less. SWA checked this assumption by modeling the home using REM/Rate, a simulation program used for analyzing energy use in residential buildings. The HERS index for this property was determined to be 100, far lower than the required score.

There could be several reasons for this. First, the SmartRegs' prescriptive checklist does not give any credit for insulation in a crawlspace ceiling ( $R-11$ in the ceiling of this crawlspace) if the mechanical equipment and/or any of the ductwork are located in that space.

The City's reasoning behind this is that one of the goals of the SmartRegs program is to promote the most cost-effective, energy efficient improvements while improving living conditions-comfort, safety, indoor air quality etc.for the renters. The city of Boulder feels that converting unconditioned crawlspaces to conditioned, air sealed, warm, dry spaces is one of the measures that will help them achieve these goals. When modeling this home, the insulation in the crawlspace was included, and therefore, could result in a lower HERS index than would correspond to the achieved 100 points on the SmartRegs checklist.

\section{Cold Climate Region: Case Study \#1 SmartRegs Compliance}

\section{Facts about SmartRegs}

2 Compliance Paths: Prescriptive or Performance

- Prescriptive: 100 points on Checklist

- Performance: HERS Index $<=120$

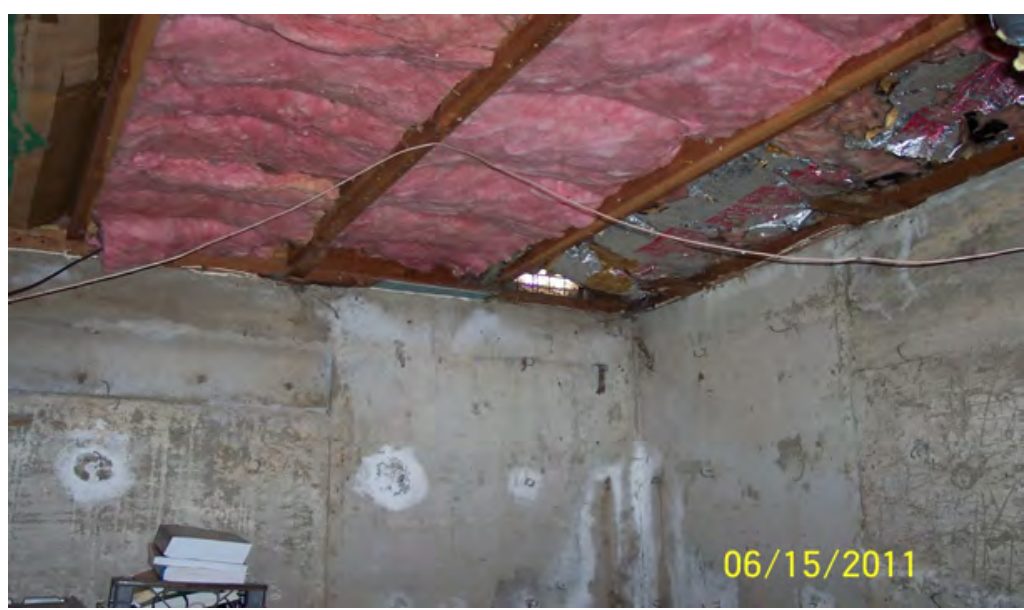

This home receives no credit for the crawlspace ceiling insulation because the majority of the ductwork is located here.

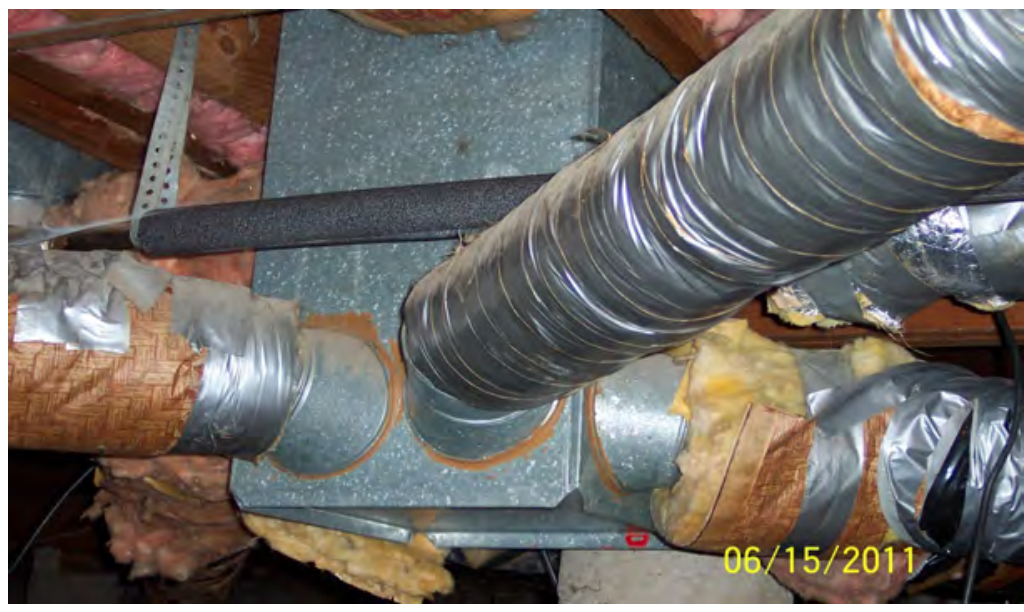

Main supply plenum from down flow furnace with supply branch takeoffs. $99 \%$ of the supplies are located in this crawl.

Also, the affects of conditions like solar exposure, window to wall ratio and roof color are not evaluated on the checklist but can drastically affect a HERS Index, especially in a sunny climate like Colorado's.
Steven Winter Associates, Inc. tel 203-857-0200 fax 203-852-0741 tel $212-564-5800$ fax 212-741-8673 tel 202-628-6100 fax 202-393-5043 


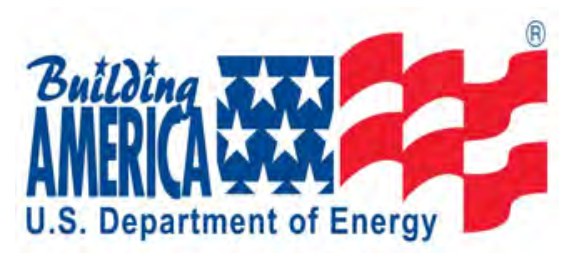

Boulder, CO

\section{Cold Climate Region: Case Study \#1 Utility Bill Analysis

SmartRegs requirements were adopted to meet the city's sustainability objectives including environmental health, economic vitality and social equity. According to current statics, rental properties comprise approximately 50 percent of Boulder's housing stock ${ }^{1}$. Therefore, by requiring property owners to upgrade rental properties, the SmartRegs program aids in advancing Boulder's community sustainability objectives, and will hopefully result in lower energy bills for tenants.

Predicted annual utility bills for this property are displayed in the graph to the right. REM/Rate predicts an overall annual utility bill of $\$ 1022$ : about $1 / 3$ (\$361) is attributed to heating .

To better analyze programs like SmartRegs, comparisons to actual utility bills are critical. Unfortunately, obtaining utility bills from major providers has been and remains incredibly difficult, even with signed consent forms from homeowners or renters. While this is not necessarily a barrier to program implementation, it is a huge barrier to improving these programs and ensuring that the upgrades being recommended are effective from an energy reduction and a cost-effectiveness standpoint. Removing this barrier is essential in meeting long term program goals.

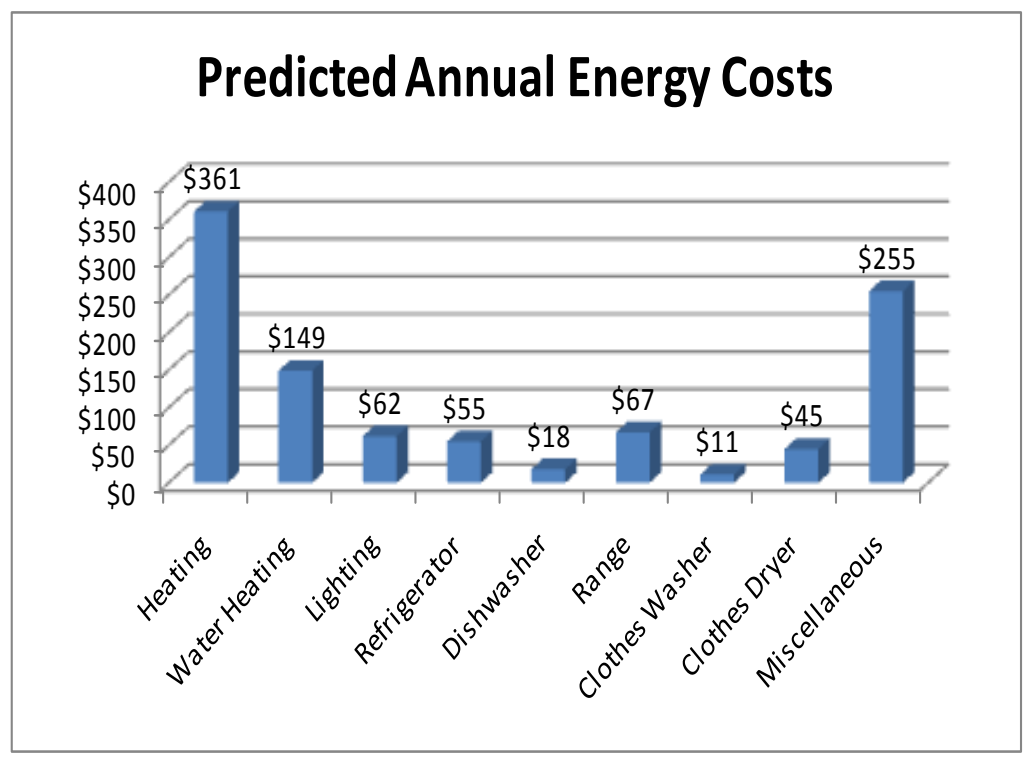

Predicted Monthly Utility Bills from REM/Rate.

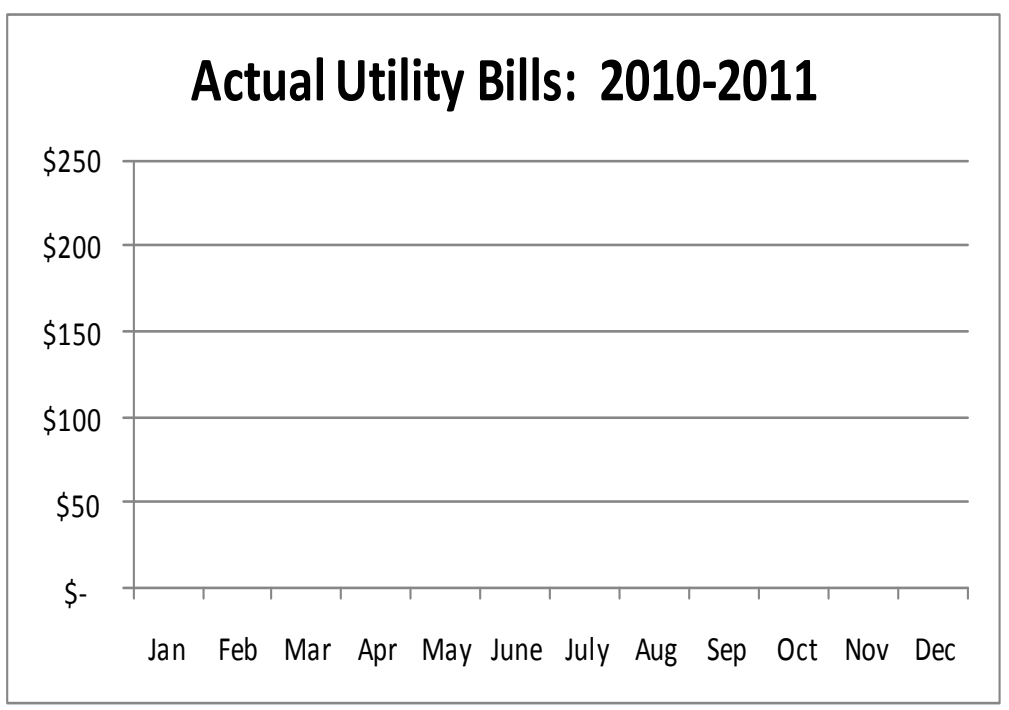

Actual Utility Bills Could Not Be Obtained. 


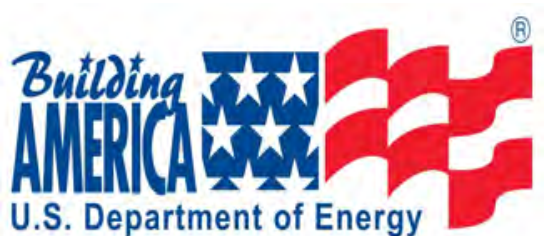

\section{Cold Climate Region: Case Study \#1 Rental Property Owner's Story

\section{Boulder, $\mathrm{CO}$}

The property owner was interviewed to determine his feelings and concerns about Boulder's new SmartRegs ordinance. A summary of his opinions and suggestions for improvements are below.

Q: Why did you decide to participate now and not wait till later in the process?

A: The owner has a long-term interest in energy conservation; "I'm way out in front of what's commonplace for rentals." He also felt that if upgrades were needed, he could determine the most economical course of action and allow for future planning for appliance replacement. This owner owns two rentals and both passed (SmartRegs), so there was no benefit for him in that way (no action required), though if this house had more sun, he would also have added PV.

\section{Q: How long has the owner owned this property?}

A: Thirty-six years, since 1975.

Q: Are you educating the occupants about what and why renovations are taking place and how it will benefit them?

A: It's easy with this tenant because he works for Boulder Housing Authority. The tenant posted a copy of the SmartRegs certificate on the refrigerator for all to see!

\section{Q: What's the vacancy rate for your property?}

A: Zero

\section{Q: What are your thoughts or comments for others?}

A: This owner felt that the focus of this program should be on reducing use of air conditioning because of peak summer demand pushing the city to more power plants. He suggested that solar arrays should be oriented to offset late afternoon summer to aid in reducing summer peak demands. He is also a big proponent of ground source heat pumps and feels they should be used more widely.

NOTE: SWA feels there are arguments for and against ground source heat pumps, and each application should be analyzed individually to determine if the technology is a good fit.

Q. What is your normal maintenance routine - i.e., every few months, once a year, on occupant turn over?

A: Maintenance and general improvements are done during tenant transition, and during crises! The owner relies on the tenant to advise when things are broken.

Steven Winter Associates, Inc. is the lead for the Department of Energy's Building America team called the Consortium for Advanced Residential Buildings (CARB).

CARB would like to thank Populus, LLC, a sustainable design consulting firm and the program administrator for the City of Boulder's SmartRegs program, for their expertise, time and assistance in creating these case studies. 


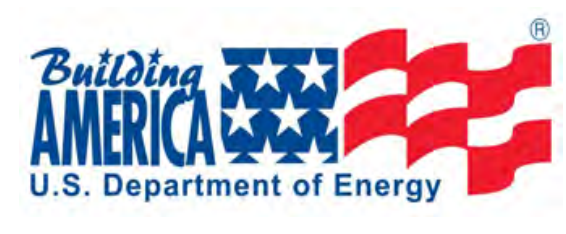

\begin{tabular}{|ll}
\hline Boulder, $\mathbf{C O}$ & \\
\hline Program & SmartRegs Ordinance \\
Location: & Boulder, Colorado \\
Building Type: & Single Family Detached \\
Building Size: & $1,512 \mathrm{ft}^{2}$ \\
Foundation: & Unconditioned Crawlspace \\
Configuration: & 3 bedrooms, 2 baths \\
SWA Contact: & Lois Arena \\
\hline
\end{tabular}

This single family detached home is located in Boulder, $\mathrm{CO}$, in an area well known for its small, ranch style homes very often used as rental property. Typical of homes built in the 1950's and 1960's in Boulder, it is a 3 bedroom, 2 bathroom single-story house just over $1,500 \mathrm{ft}^{2}$ built over a crawlspace foundation.

The property manager for this rental became involved in the SmartRegs process early on because the owner of the property is on the board of a rental housing association in Boulder. The owner was interested in stepping through the process so that he could share the experience and lessons learned with members of the association. This home was actually used as a training site for several property owners.

After experiencing the process and understanding the requirements first hand, the property manager for this rental convinced several of her other property owners to sign up early for the SmartRegs audit. Basically, she wanted to determine if their rental properties complied with the City of Boulder's new requirements, and if they didn't, she wanted to ensure they had enough time to plan for needed upgrades.

Efficiency levels in this property were consistent with its year of construction (see table at right). Other than a couple of window replacements, no energy improvements appear to have been made to date. All ductwork and the heating system are located in the vented, unconditioned crawlspace. The addition at the back of the home has slightly higher wall and ceiling R-values than the original structure, but are not to the levels required by current codes.

Based on the blower door result of 2711 cfm@50 pascals, the estimated infiltration rate of this home is approximately 0.59 air changes per hour under natural conditions (ACHn) or 10.5 ACH@50 pascals.

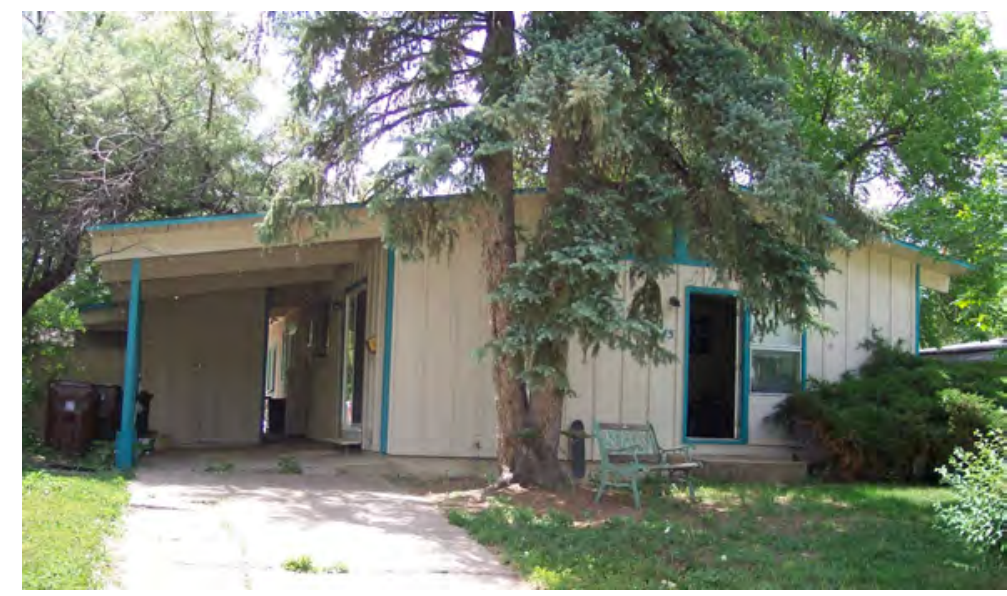

With an initial score of only 89 points on the SmartRegs checklist, this property owner must make some energy efficiency improvements to comply with Boulder's new ordinance.

\section{Energy Efficient Features \\ Attic: $\quad 75 \%$ R10 rigid polyisocyanurate 25\% R-19 batts \\ Walls: $\quad$ Combination of R-11 \& R-13 fiberglass batts \\ Windows: Combination of double metal, low-e double vi- nyl, single wood w/ storms \\ Foundation: Crawlspace $75 \%$, Uninsulated, R-0 Slab 25\%, Uninsulated, R-0 \\ Heating: $\quad$ Forced air, natural gas, atmospheric, standing pilot in unconditioned space-68 AFUE \\ Cooling: None \\ Ductwork: Uninsulated in unconditioned crawl, extremely leaky \\ Hot Water: Atmospheric, natural gas, conditioned space- $0.56 \mathrm{EF}$}

Air Leakage: 10.5 ACH@50 pascals, 0.59 ACHn

\section{Additional SmartRegs Features \\ None}

\section{SmartRegs Checklist Score*: 89 points}

(The final score must be $\geq 100$ )

\section{HERS Index: 192}

*100 points on the SmartRegs checklist should approximately equate to a HERS index of 120 .

${ }^{* *}$ Auditor assumed a furnace AFUE of 80 , should have been 68 according to RESNET standards. This would result in a SmartRegs score of 76 . www.swinter.com

50 Washington St. 6th Fl, Norwalk, CT 06854 307 7th Ave. Ste. 1701, New York, NY 10001 1112 16th St., NW Ste. 240, Washington, DC 20036 tel 203-857-0200 fax 203-852-0741 tel 212-564-5800 fax 212-741-8673 tel 202-628-6100 fax 202-393-5043 


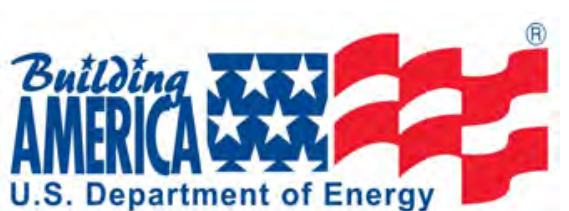

\section{Boulder, CO}

The owner of this property opted to use the prescriptive method of compliance and have the auditor fill out a checklist rather than perform energy modeling to determine if the property was in compliance. Based on the auditors assessment, this home scored 89 points on the SmartRegs checklist and is, therefore, not in compliance with the program. Because the minimum allowable score is 100 points, the owner will have to improve the property by 2019 in order to maintain the rental permit required by the City of Boulder.

When creating the prescriptive checklist, the authors set out to create a threshold that would apply to all homes. After extensive analysis, it was determined that 100 points on the checklist should correspond to a HERS index of 120 points, more or less. With a SmartRegs score of 89 , the HERS index for this home should be considerably higher than 120.

SWA checked this assumption by modeling the home using REM/Rate, a simulation program used to analyze the energy use of residential buildings. As anticipated, the HERS index for this property was determined to be 192, significantly higher than 120.

Another goal in creating the SmartRegs checklist was to design a tool that would naturally lead property owners to the most cost-effective and highest impact improvements. For example, many more points are awarded for insulating an uninsulated attic than are given for insulating a slab foundation. Assuming both assemblies are poorly insulated, attic insulation will save much more money, be more cost-effective and is generally easier to accomplish than slab insulation.

Various improvement options for this property owner include:

- Crawlspace: insulating, air sealing and installing a vapor barrier; (14 points-includes points for putting ductwork in conditioned space)

- $\quad$ Reducing duct leakage to $20 \mathrm{cfm} / 100 \mathrm{ft} 2 ;$ (5 points)

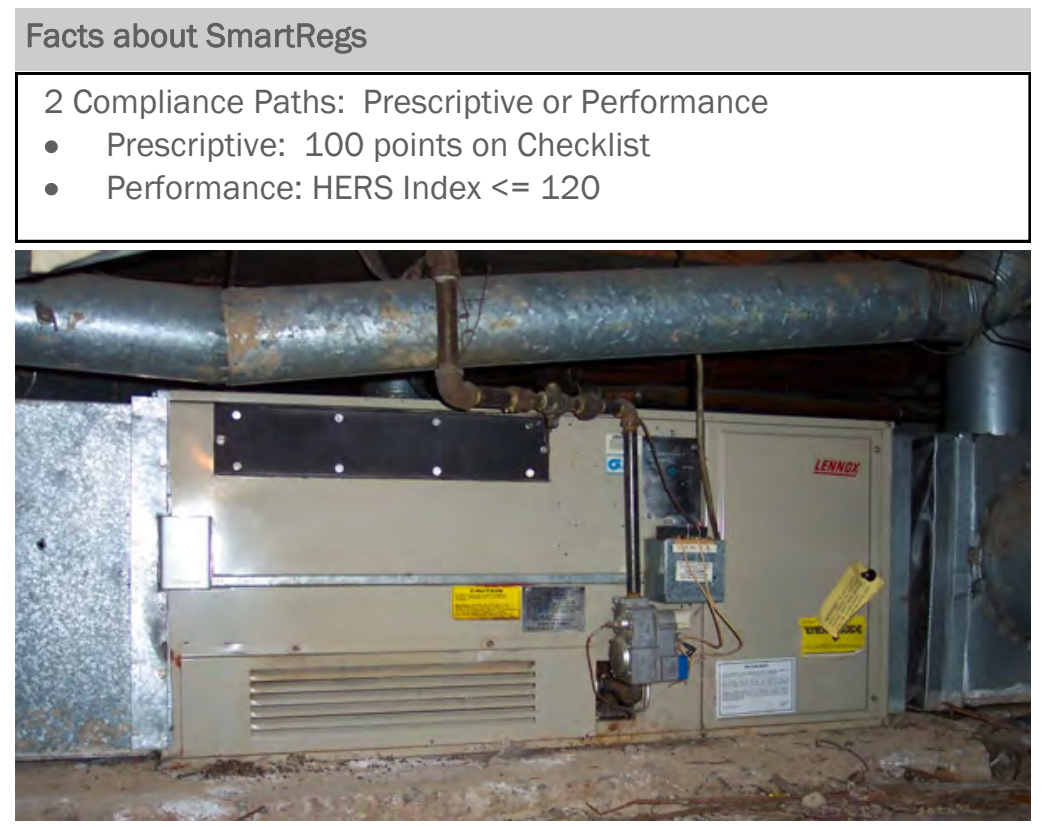

\section{All ductwork and the heating system were located in the vented, uninsulated crawlspace.}

- Installing compact fluorescent lighting (CFL's) throughout the home; (7 points)

- Installing a programmable thermostat; (1 point)

- Replacing the furnace with a high efficiency, 90+ AFUE model. (17 points)

The property owner is free to implement any combination of energy improvements as long as the final checklist score is at least 100. There are several combinations that would bring this home into compliance. For example, encapsulating and conditioning the crawlspace, reducing the duct leakage and installing a setback thermostat and CFL's would bring this home's true score (see footnote on previous page) to 103. The corresponding HERS index for the home would be 142. Although still higher than the intended HERS index of 120 points, this is a huge improvement Replacing the furnace, sealing the ductwork and installing CFL's also brings the home into compliance with a SmartRegs score of 105, but again the HERS index is only reduced to 134 , not 120 .

There could be several reasons why the improved cases do not achieve a HERS Index of 120, but score 100 or more points on the SmartRegs checklist. For instance, the affects of window to wall ratios, solar exposure and roof color are not evaluated on the checklist but can drastically affect a HERS Index, especially in a climate like Colorado's. A score of 100 was meant to approximately equate to a HERS Index of 120. It is anticipated that some homes will exceed and some will be under this threshold.
wwW.swinter.com

50 Washington St. 6th FI, Norwalk, CT 06854 307 th Ave. Ste. 1701, New York, NY 10001

1112 16th St., NW Ste. 240, Washington, DC 20036 tel 203-857-0200 fax 203-852-0741 tel $212-564-5800$ fax 212-741-8673 tel 202-628-6100 fax 202-393-5043 


\section{Boulder, CO}

SmartRegs requirements were adopted to meet the city's sustainability objectives including environmental health, economic vitality and social equity. According to current statistics, rental properties comprise approximately 50 percent of Boulder's housing stock ${ }^{1}$. Therefore, by requiring property owners to upgrade rental properties, the SmartRegs program aids in advancing Boulder's community sustainability objectives, and will hopefully result in lower energy bills for tenants.

Predicted monthly utility bills for this property as it existed at the time of the initial inspection are displayed in the graph to the right. REM/Rate predicts an annual utility bill of $\$ 2,343$ : about $53 \%, \$ 1,243$, is attributed to heating.

Utility bill savings for the first option package discussed on the previous page-encapsulating and conditioning the crawlspace and installing a setback thermostat and CFL's (HERS index of 142) results in predicted utility bill savings for the occupants of over $\$ 464$ per year.

The second option-replacing the furnace, sealing the ductwork and installing CFL's (HERS index of 134 ) - results in predicted energy savings of $\$ 492$ per year.

Predicted emissions reductions are significant as well. Both upgrade packages are predicted to reduce $\mathrm{NO}_{x}, \mathrm{SO}_{2}$ and $\mathrm{CO}_{2}$ by more than $20 \%$.

To better analyze programs like SmartRegs, comparisons to actual utility bills are critical. Unfortunately, obtaining utility bills from major providers has been and remains incredibly difficult, even with signed consent forms from homeowners or renters. While this is not necessarily a barrier to program implementation, it is a huge barrier to improving these programs and ensuring that the upgrades being recommended are effective from an energy reduction and a cost-effectiveness standpoint. Removing this barrier is essential in meeting long term program goals.

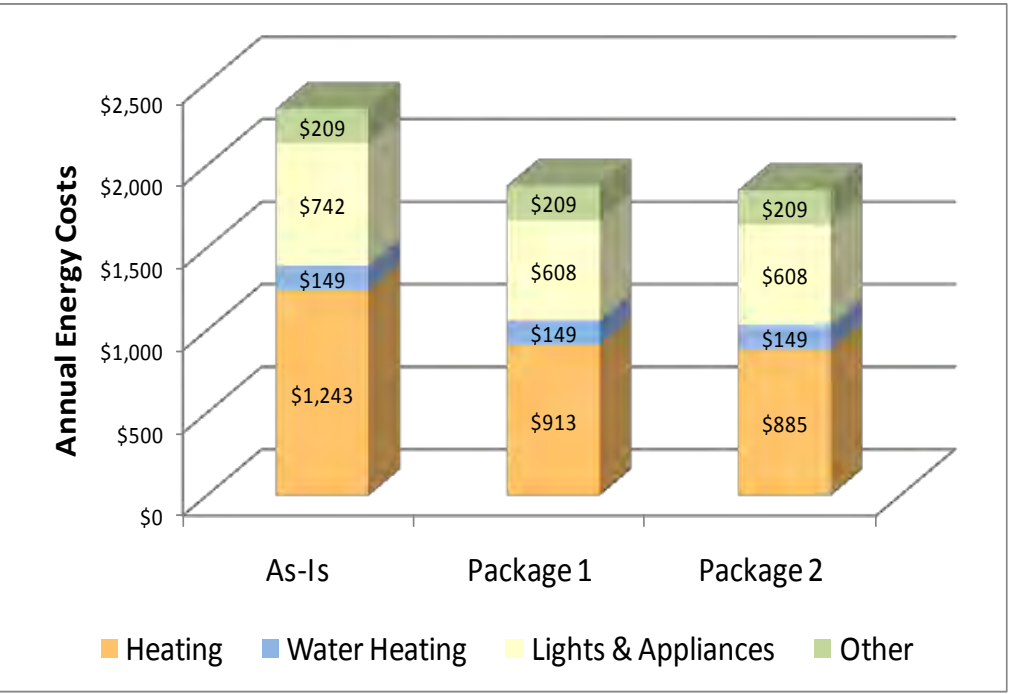

Predicted utility bills from REM/Rate.

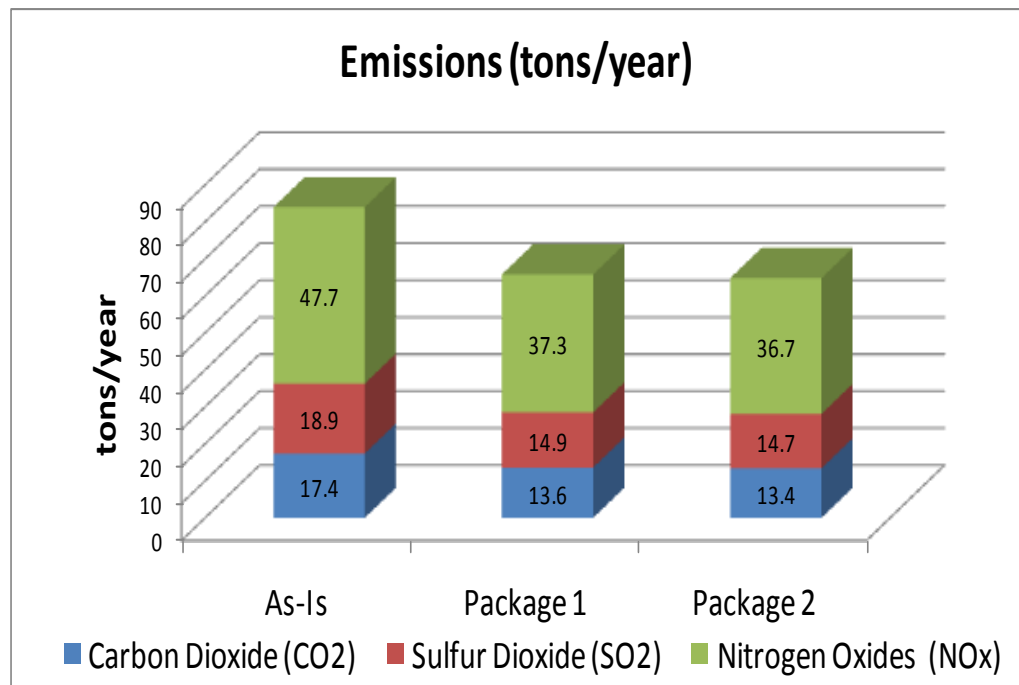

Predicted $\mathrm{NO}_{x}, \mathrm{SO}_{2}$, and $\mathrm{CO}_{2}$ emissions from REM/Rate.

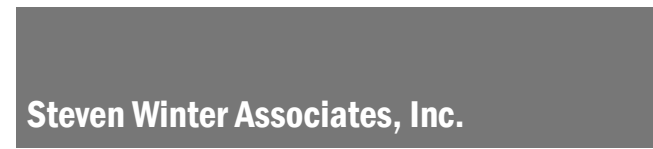

www.swinter.com

50 Washington St. 6th FI, Norwalk, CT 06854 307 7th Ave. Ste. 1701, New York, NY 10001

1112 16th St., NW Ste. 240, Washington, DC 20036 tel 203-857-0200 fax 203-852-0741 tel $212-564-5800$ fax 212-741-8673 tel 202-628-6100 fax 202-393-5043 


\section{Boulder, CO}

The property manager was interviewed to determine her feelings and concerns about Boulder's new SmartRegs ordinance. A summary of her opinions and suggestions for improvements are below.

Q: Why did you decide to participate now and not wait till later in the process?

A: The owner of this property is on the Boulder Rental Association Board and went through the process for educational purposes for the members of the Association.

This property manager was involved in an outreach/education effort to help inform other property managers and property owners about the SmartRegs program. The owner is on board with the requirements. Both owner and manager express that the program is not as difficult to comply with as anticipated.

\section{Q: How long has the owner owned this property?}

A: The owner has owned the property more than 30 years.

Q: Are you educating the occupants about what and why renovations are taking place and how it will benefit them?

A: The manager tries to inform the tenants about what is happening and how it will benefit them. She is not actively marketing the features yet.

\section{Q: What's the vacancy rate for your property?}

A: Basically zero. There are no problems with vacancy in Boulder.
Q: What is your normal maintenance routine - i.e., every few months, once a year, on occupant turn over?

A: Maintenance is performed at occupant turnover usually. Occupants typically turn over every year. Upgrades are performed as needed - i.e., a window doesn't work. Then just that window is replaced.

Q: What has been the biggest challenge for you throughout this process?

A: The biggest challenge has been distilling all the information down so that it is easy for the owners to understand. The manager would like educational tools to make this task easier.

\section{Q: What would you like other property owners to know?}

A: The process wasn't as difficult as she and the property owners originally anticipated. The information which was circulating about how much money the property owners would have to spend was not accurate.

\section{Q: Do you have any additional concerns about the program?}

A: The major concern is that the Boulder city council will keep increasing the requirements of the program.

Steven Winter Associates, Inc. is the lead for the Department of Energy's Building America team called the Consortium for Advanced Residential Buildings (CARB).

CARB would like to thank Populus, LLC, a sustainable design consulting firm and the program administrator for the City of Boulder's SmartRegs program, for their expertise, time and assistance in creating these case studies. 


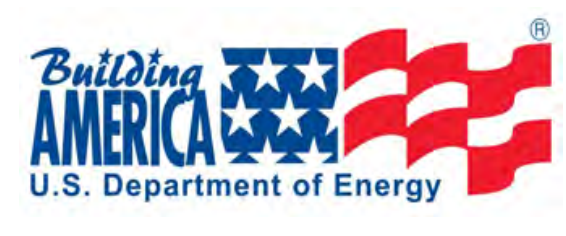

\begin{tabular}{|ll|}
\hline Boulder, CO & \\
\hline Program & SmartRegs Ordinance \\
Location: & Boulder, Colorado \\
Building Type: & Single Family Detached \\
Building Size: & $1,262 \mathrm{ft}^{2}$ \\
Foundation: & Unconditioned Crawlspace \\
Configuration: & 3 bedrooms, 2 baths \\
SWA Contact: & Lois Arena \\
\hline
\end{tabular}

The southeastern section of Boulder, CO is an area well known for its small, ranch style homes very often used as rental property. This single family detached home is typical of homes built in the 1950's and 1960's in that section of Boulder. It is a 3 bedroom, 2 bathroom single-story house approximately $1,262 \mathrm{ft}^{2}$ built over a crawlspace foundation.

The property owner for this rental became involved in the SmartRegs process early on for a few reasons. First, her rental license was due for renewal, and she reasoned this was a good time to go through the process. Second, she was hoping to bring the property into compliance sooner rather than later in case the city made the requirements even stricter over time. Lastly, she is the editor of a newspaper in a nearby town and was interested in sharing her experience with her readers.

Efficiency levels in this property were consistent with its year of construction (see table at right). Although the owner is diligent about keeping the property in good condition and performing upgrades as components wear out, other than a couple of window replacements, few energy improvements appear to have been made to date.

This is not uncommon when the renters are responsible for the utility bills. There is little incentive for property owners to make the homes more efficient if they are not responsible for the energy costs. Owner occupants are more likely to insulate and air seal their homes than are rental property owners as it directly affects their comfort and monthly finances.

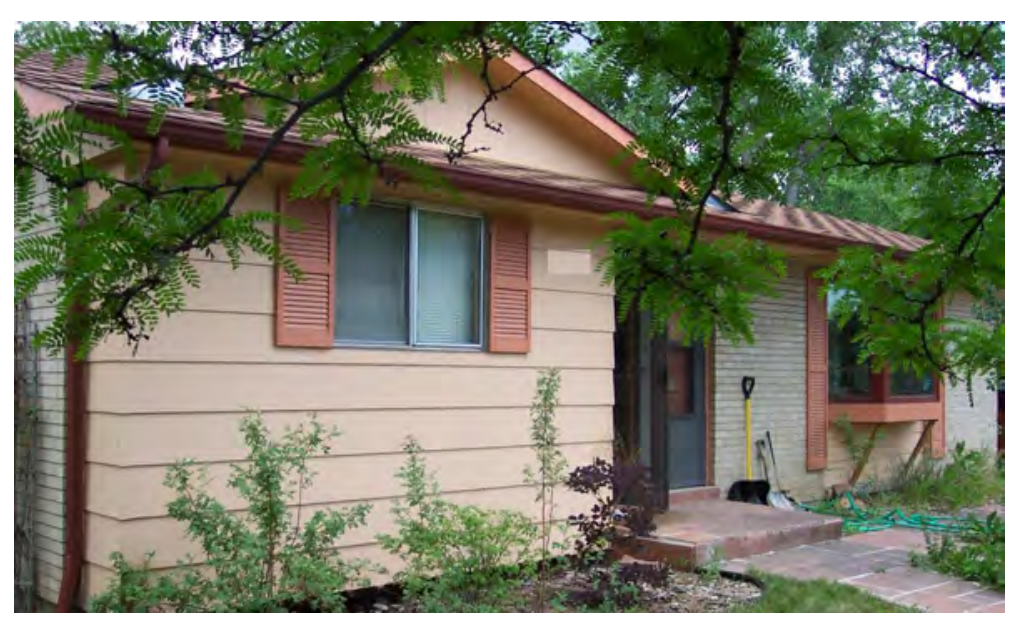

This home's initial score was 62 points on the SmartRegs checklist. This property owner must make some energy efficiency improvements to comply with Boulder's new ordinance.

\section{Energy Efficient Features \\ Attic: R-11 batts \\ Walls: Uninsulated \\ Windows: Combination of double metal, low-e double wood \\ Foundation: Crawlspace ceiling R-19, 20\% void \\ Heating: Forced air, natural gas, 80 AFUE in uncondi- \\ Cooling: None \\ Ductwork: Uninsulated in unconditioned crawl \\ Hot Water: Atmospheric, natural gas, conditioned space, $0.56 \mathrm{EF}$}

Air Leakage: 16.4 ACH@50 pascals, $0.88 \mathrm{ACHn}$

\section{Additional SmartRegs Features}

Low-flow faucets and showerheads

\section{SmartRegs Checklist Score*: 62 points}

(The final score must be $\geq 100$ )

\section{HERS Index: 180}

*100 points on the SmartRegs checklist should approximately equate to a HERS index of 120.

${ }^{* *}$ Original score of 64 was adjusted for a volume correction, the result is a SmartRegs score of 62.
Steven Winter Associates, Inc. www.swinter.com

50 Washington St. 6th Fl, Norwalk, CT 06854 307 7th Ave. Ste. 1701, New York, NY 10001 1112 16th St., NW Ste. 240, Washington, DC 20036 tel 203-857-0200 fax 203-852-0741 tel 212-564-5800 fax 212-741-8673 tel 202-628-6100 fax 202-393-5043 


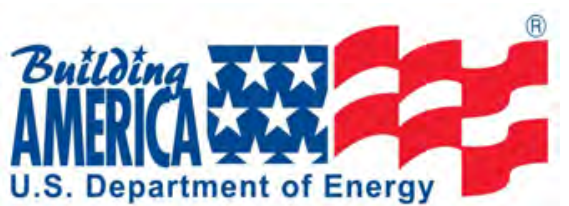

\section{Boulder, CO}

As has been quite common to date, the owner of this property opted to use the prescriptive method of compliance and have the auditor fill out a checklist rather than perform energy modeling to determine if the property was in compliance. The checklist is quicker than modeling, provides answers right on site and does not require the additional time and expense of duct leakage testing. If compliance can be gained without modeling, the checklist is a more economical option.

Because the minimum allowable score is 100 points, the owner will have to improve the property by 2019 in order to maintain the rental permit required by the City of Boulder.

Considering that 100 points on the SmartRegs checklist should approximately equate to a HERS index of 120 points, the HERS index for this home should be considerably higher than 120 . For the purpose of this case study, this home was modeled using REM/Rate, a simulation program used to analyze the energy use of residential buildings. As anticipated, the HERS index for this property was determined to be 180 , significantly higher than 120.

One goal in creating the SmartRegs checklist was to design a tool that would naturally lead property owners to the most cost-effective and highest impact improvements. For example, many more points are awarded for insulating an uninsulated attic than are given for insulating a slab foundation. Assuming both assemblies are poorly insulated, attic insulation will save much more money, be more cost-effective and is generally easier to implement than slab insulation.

During the first round of development, program developers had intended that no points would be gained if the attic insulation was less than R-19 (see SmartRegs checklist section at right).

\section{Facts about SmartRegs}

2 Compliance Paths: Prescriptive or Performance

- Prescriptive: $\geq 100$ points on Checklist

- Performance: HERS Index $<=120$

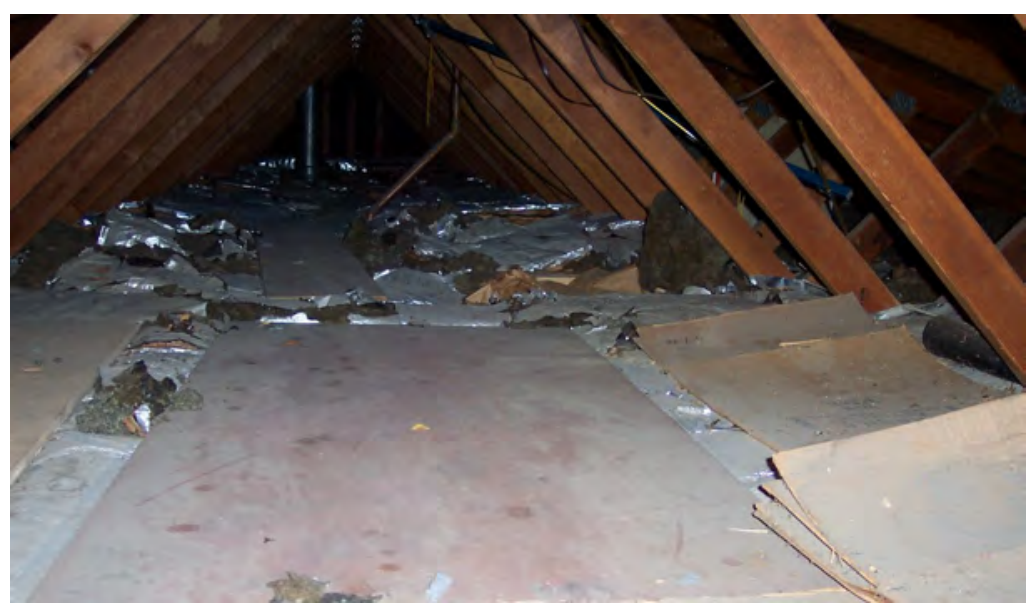

Attic is only insulated to R-11.

ATTIC

\begin{tabular}{|lcccc|}
\multicolumn{1}{c}{ TYPE } & $\mathbf{2 5 \%}$ & $\mathbf{5 0 \%}$ & $\mathbf{7 5 \%}$ & $\mathbf{1 0 0 \%}$ \\
\hline No Insulation & 0 & 0 & 0 & 0 \\
\hline R-19 & 6 & 12 & 18 & 24 \\
\hline R-30 & 6 & 13 & 19 & 26 \\
\hline R-38 or Better & 7 & 13 & 20 & 26 \\
\hline Shared Ceilings & 7 & 14 & 20 & 27 \\
\hline
\end{tabular}

\section{Attic Section of SmartRegs Checklist}

Unfortunately, because neither the checklist nor the manual mention how to handle insulation levels between 0 and 19, the same points are currently being awarded to homes with R-19 insulation and homes with only R-11. Awarding so many points removes the incentive to insulate these poorly insulated attics, an upgrade that would be cost-effective, benefit the occupants and help the City of Boulder achieve it's energy reduction goals. Administrators are aware of this issue and intend to make revisions in the future.
Steven Winter Associates, Inc. www.swinter.com

50 Washington St. 6th FI, Norwalk, CT 06854 3077 th Ave. Ste. 1701, New York, NY 10001

1112 16th St., NW Ste. 240, Washington, DC 20036 tel 203-857-0200 fax 203-852-0741 tel 212-564-5800 fax 212-741-8673 tel 202-628-6100 fax 202-393-5043 


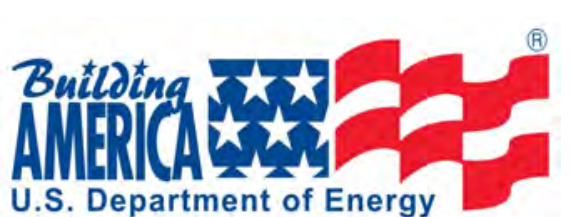

Boulder, CO

Various improvement options for this property owner include:

- Crawlspace: insulating the walls to R-19, air sealing and installing a vapor barrier (16 points-includes points for bringing ductwork into conditioned space);

- Reducing duct leakage to $20 \mathrm{cfm} / 100 \mathrm{ft}^{2}$ (5 points);

- Insulating the attic to R-38 (2 points);

- Replacing the furnace with a high efficiency, 90+ AFUE model (17 points);

- Installing an ENERGY STAR refrigerator <= $450 \mathrm{kWh} / \mathrm{yr}$ (3 points);

- Blowing insulation into the exterior walls, R12 (20 points);

- Reducing the air leakage to $0.59 \mathrm{ACHn}$ (2 points);

The property owner is free to implement any combination of energy improvements as long as the final checklist score is at least 100 . There are several combinations that would bring this home into compliance For example the following two packages would bring the SmartRegs score to 100 points.

\section{Package \#1: (+38 points)}

- Encapsulating and conditioning the crawlspace,

- increasing the attic insulation to R-38,

- Insulating the exterior walls to R-12

This package results in a HERS Index of 114 and a SmartRegs score of 100.

\section{Package \#2: (+38 points)}

- Encapsulating and conditioning the crawlspace,

- Increasing the attic insulation to R-38,

- Install a high efficiency furnace

- Replace refrigerator w/ $450 \mathrm{kWh} / \mathrm{yr}$ unit

Package \#2 results in a HERS Index of 121 and a SmartRegs score of 100.

Note that, while the HERS Indices are slightly different for both upgrade scenarios where the SmartRegs scores are 100, both HERS Indices are very near the intended threshold of 120 .

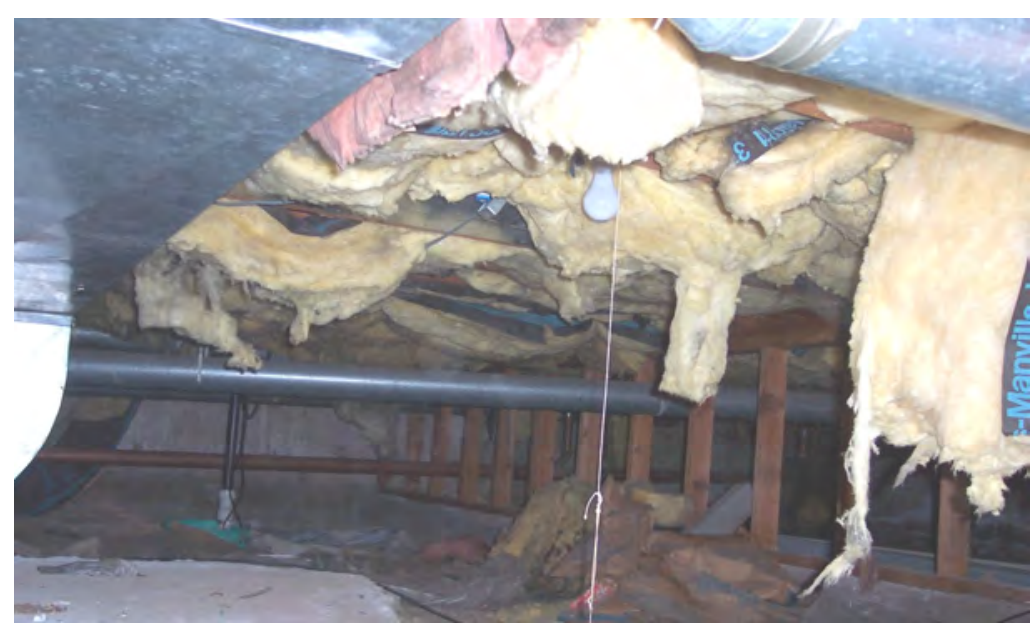

All ductwork and the heating system were located in the vented crawlspace. Insulation was falling down in multiple locations.

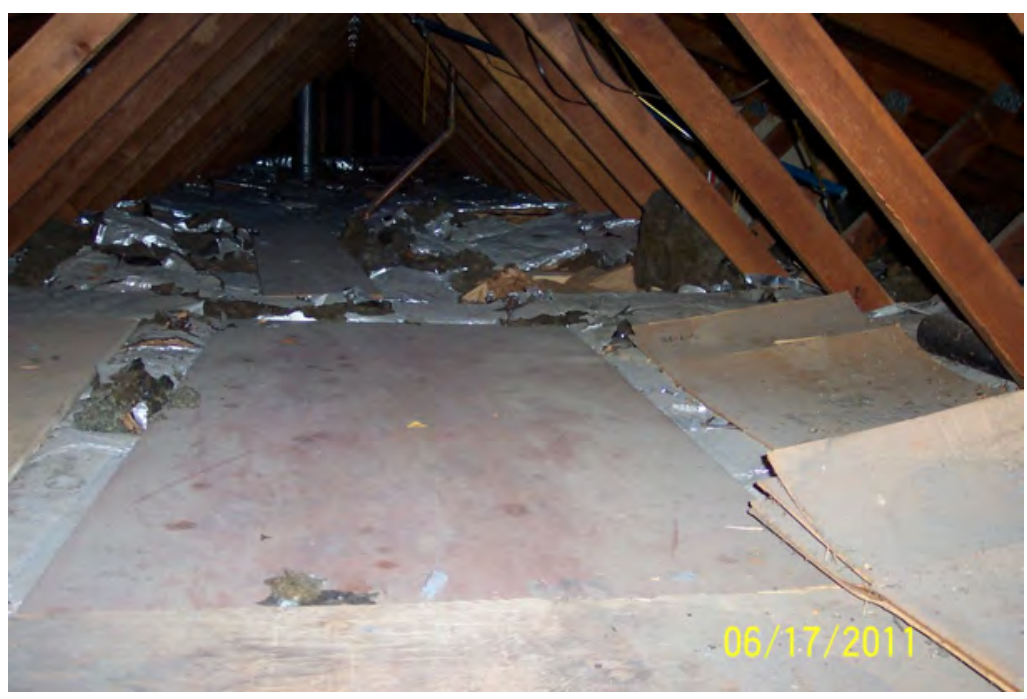

Attic is only insulated to $R-11$.

\begin{tabular}{|c|c|c|}
\hline \multirow[b]{2}{*}{ Upgrade Items } & Package 1 & Package 2 \\
\hline & $\begin{array}{l}\text { Insulate \& Condition Crawl } \\
\text { Insulate Attic to R-38 } \\
\text { Insulate Exterior Walls }\end{array}$ & $\begin{array}{c}\text { Insulate \& Condition Crawl } \\
\text { Insulate Attic to R-38 } \\
\text { Install } 90 \text { AFUE Furnace } \\
\text { Replace Refrigerator }\end{array}$ \\
\hline \multirow{2}{*}{$\begin{array}{l}\text { SmartRegs } \\
\text { Hers Index }\end{array}$} & 100 & 100 \\
\hline & 114 & 121 \\
\hline
\end{tabular}

Steven Winter Associates, Inc. www.swinter.com

50 Washington St. 6th FI, Norwalk, CT 06854 307 7th Ave. Ste. 1701, New York, NY 10001

1112 16th St., NW Ste. 240, Washington, DC 20036 tel 203-857-0200 fax 203-852-0741 tel 212-564-5800 fax 212-741-8673 tel 202-628-6100 fax 202-393-5043 


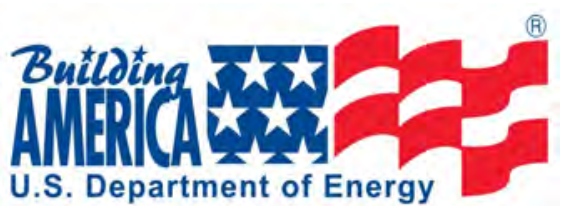

\section{Cold Climate Region: Case Study \#3 Utility Bill Analysis Page 4}

\section{Boulder, CO}

SmartRegs requirements were adopted to meet the city's sustainability objectives including environmental health, economic vitality and social equity. According to current statistics, rental properties comprise approximately 50 percent of Boulder's housing stock ${ }^{1}$. Therefore, by requiring property owners to upgrade rental properties, the SmartRegs program aids in advancing Boulder's community sustainability objectives, and will hopefully result in lower energy bills for tenants.

Predicted monthly utility bills for this property as it existed at the time of the initial inspection are displayed in the graph to the right. REM/Rate predicts an annual utility bill of $\$ 1,826$ : about $57 \%$, $\$ 1,044$, is attributed to heating.

Utility bill savings for the first option package discussed on the previous page-encapsulating and conditioning the crawlspace and insulating the attic and insulating the walls (HERS index of 114) - results in predicted energy savings of $\$ 464$ per year.

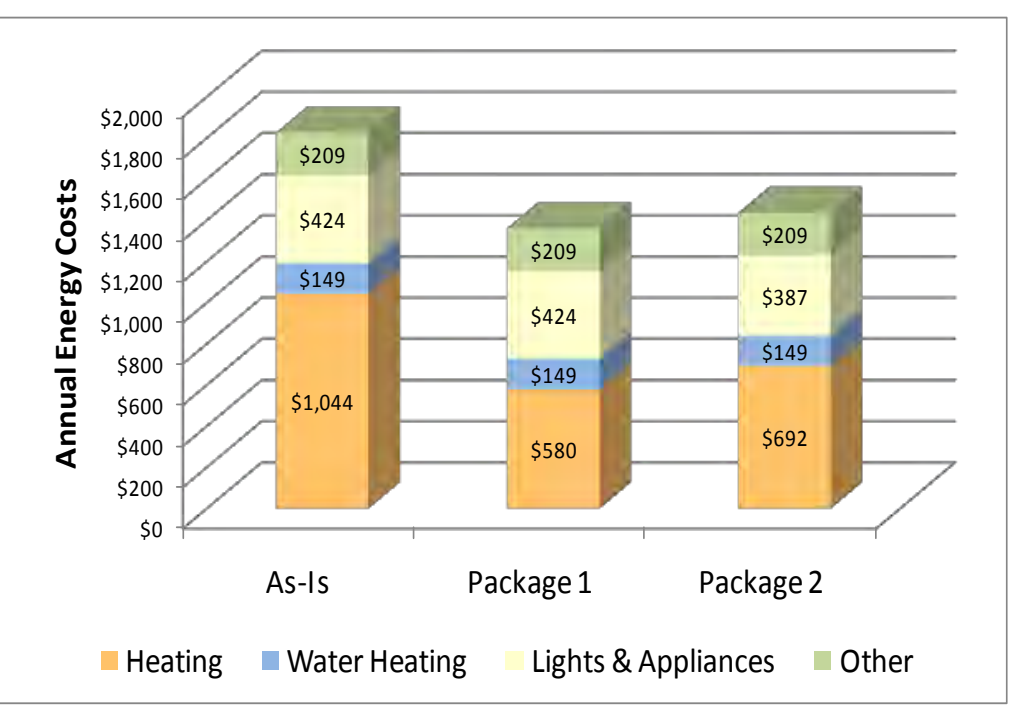

Predicted utility bills from REM/Rate.

The second option-encapsulating and conditioning the crawlspace, insulating the attic and replacing the furnace and refrigerator (HERS Index of 121) results in predicted energy savings of $\$ 389$ per year.

Predicted emissions reductions are significant as well. Both upgrade packages are predicted to reduce $\mathrm{NO}_{x}, \mathrm{SO}_{2}$ and $\mathrm{CO}_{2}$ between $9 \%$ to $30 \%$, with Package 1 resulting in the greatest savings.

To better analyze programs like SmartRegs, comparisons to actual utility bills are critical. Unfortunately, obtaining utility bills from major providers has been and remains incredibly difficult, even with signed consent forms from homeowners or renters. While this is not necessarily a barrier to program implementation, it is a huge barrier to improving these programs and ensuring that the upgrades being recommended are effective from an energy reduction and a cost-effectiveness standpoint. Removing this barrier is essential in meeting long term program goals.

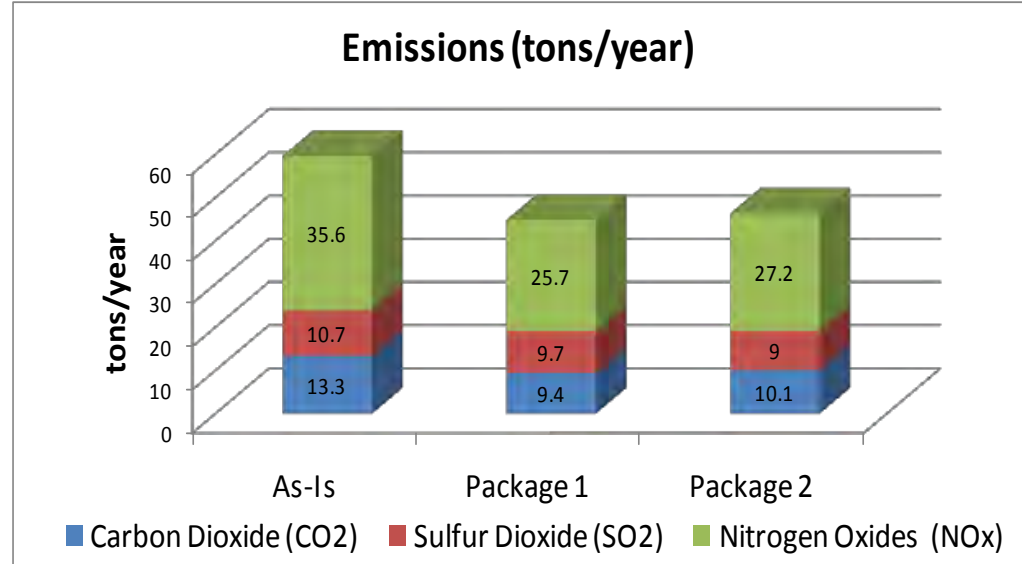

Predicted $\mathrm{NO}_{x}, \mathrm{SO}_{2}$, and $\mathrm{CO}_{2}$ emissions from REM/Rate.

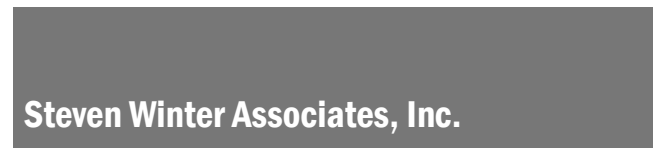

www.swinter.com

50 Washington St. 6th FI, Norwalk, CT 06854

307 7th Ave. Ste. 1701, New York, NY 10001

1112 16th St., NW Ste. 240, Washington, DC 20036 tel 203-857-0200 fax 203-852-0741 tel 212-564-5800 fax 212-741-8673 tel 202-628-6100 fax 202-393-5043 


\section{Boulder, CO}

The property owner was interviewed to determine her feelings and concerns about Boulder's new SmartRegs ordinance. A summary of her opinions and suggestions for improvements are below.

Q: Why did you decide to participate now and not wait till later in the process?

A: The owner's rental license renewal was coming up in July. She needed to know what the results of the audit would be because she does upgrades in increments - something each year. She also thought that if she complied early and the city decided to make the requirements tougher, she would be grandfathered in.

\section{Q: How long has the owner owned this property?}

A: Since 1989. This is the owner's only rental property.

\section{Q: What's the vacancy rate for your property?}

A: Although renters often stay for only one year, the owner has no problems renting this property.

Q: What is your normal maintenance routine - i.e., every few months, once a year, on occupant turn over?

A:. The owner typically performs maintenance at changeover, and whenever the occupants inform her that something needs repair.

\section{Q: What are your thoughts or comments for others?}

A: There is some confusion over how the bidding process works. This owner thought she was given only 3 contractors to chose from to perform the necessary improvements, but that is not actually the case. Owners are provided a list of over 15 approved contractors (to date) and can chose any three to provide them with bids.

She was also under the impression that the inspector pool was closed making it unfair to others who would like to participate. Populus, the program administrators, state that this is not the case.

Finally, she feels that there is a conflict of interest by allowing contractors to be inspectors.

Overall, the owner didn't think it was quite as difficult as anticipated, but feels the city is not being fair because all homeowners, not just landlords, should have to comply with the same rules.

SWA's response to the last comment is that while it may seem unfair to require this program for landlords and not all property owners, owner occupants are much more likely to improve the efficiency of their homes because it directly improves their comfort and monthly finances. Owner occupants have a much higher incentive to perform upgrades and therefore, their housing stock on average will already be much more energy efficient than the rental property housing stock.

Steven Winter Associates, Inc. is the lead for the Department of Energy's Building America team called the Consortium for Advanced Residential Buildings (CARB).

CARB would like to thank Populus, LLC, a sustainable design consulting firm and the program administrator for the City of Boulder's SmartRegs program, for their expertise, time and assistance in creating these case studies. 


\section{Cold Climate Region: Case Study \#4 City of Boulder, SmartRegs Ordinance Single Family Detached, Historic}

\begin{tabular}{|ll|}
\hline Boulder, CO & \\
\hline Program & SmartRegs Ordinance \\
Location: & Boulder, Colorado \\
Building Type: & Single Family Detached \\
Building Size: & $2252 \mathrm{ft}^{2}$ \\
Foundation: & Conditioned Basement \\
Configuration: & 3 bedrooms, 2 baths \\
SWA Contact: & Lois Arena \\
\hline
\end{tabular}

This single family detached rental home is located in Boulder's highly desirable Mapleton Hill neighborhood. It is a 3 bedroom, 2 bathroom two-story house approximately $2252 \mathrm{ft}^{2}$ built over a conditioned, unfinished basement/crawlspace foundation. The home was built in 1911 and holds a historic designation, which means little can be done to the outside of the building without written approval from the City.

The property owner for this rental became involved in the SmartRegs process early on for a few reasons. First, she is a real estate broker who believes that complying with the latest requirements is smart business decision, because buyers will factor this in to their purchasing decision. Also, she argues that since landlords must comply with these regulations anyway, she might as well make any necessary improvements sooner rather than later. Besides this, the owner sees herself as environmentally conscious and believes that improving the energy efficiency of her properties is the right thing to do.

Efficiency levels of the building shell-walls, attic and foundation-were consistent with its year of construction (see table at right), but the heating and cooling systems have been upgraded with high efficiency equipment and the ductwork, where accessible, has been sealed. At the time of the inspection for this case study, the owner was employing a carpenter, who specializes in historic properties, to perform extensive air sealing for her.

This property was between rentals when this case study was conducted because of the extent of the improvements being done, but like all the other landlords interviewed, this owner indicated that she has never had any problems renting her properties in Boulder.

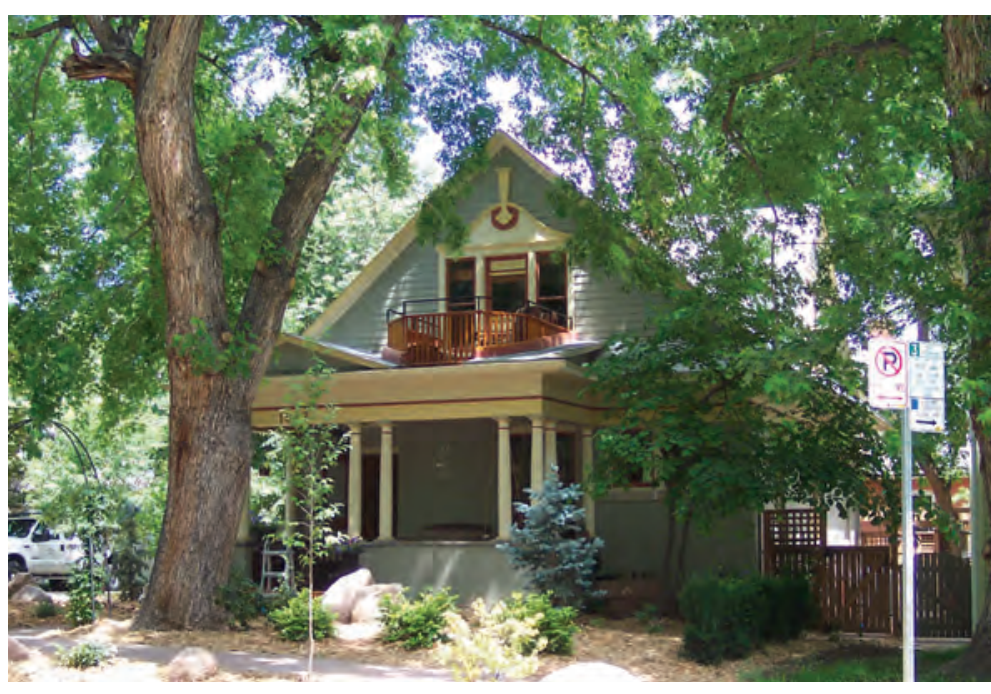

This historic home scored 87 points on the SmartRegs checklist. The property owner must make some energy efficiency improvements to comply with Boulder's new ordinance.

\author{
Energy Efficient Features \\ Attic: R-11 rock wool \\ Walls: Uninsulated \\ Windows: Single pane wood \\ Foundation: Conditioned basement/crawlspace R-0 \\ Heating: $\quad$ Forced air, natural gas, 90+ AFUE in condi- \\ tioned basement \\ Cooling: $\quad$ SEER 15 \\ Ductwork: In conditioned basement \\ Hot Water: Atmospheric, natural gas, conditioned space, \\ $0.58 \mathrm{EF}$
}

Air Leakage: 16.6 ACH@50 pascals, 0.90 ACHn

\section{Additional SmartRegs Features}

None

\section{SmartRegs Checklist Score*: 87 points \\ (The final score must be $\geq 100$ )}

\section{HERS Index: 155}

*100 points on the SmartRegs checklist should approximately equate to a HERS index of 120.

${ }^{* *}$ Adjustments were made to auditor's original score of 75 . See Compliance section on page 2 for explanation of adjustments.
Steven Winter Associates, Inc. www.swinter.com

50 Washington St. 6th FI, Norwalk, CT 06854 307 7th Ave. Ste. 1701, New York, NY 10001 1112 16th St., NW Ste. 240, Washington, DC 20036 tel 203-857-0200 fax 203-852-0741 tel $212-564-5800$ fax 212-741-8673 tel 202-628-6100 fax 202-393-5043 


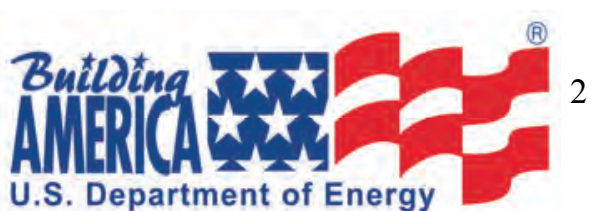

\section{Boulder, CO}

This property owner, like many others, opted to use the prescriptive method of compliance and have the auditor fill out a checklist rather than perform energy modeling to determine if the property was in compliance. A SmartRegs score of 100 is meant to approximately equate to a HERS Index of 120. It is anticipated that some homes will exceed and some will be under this threshold.

Although the auditor originally calculated an as-is score of 75 on the SmartRegs checklist, a few corrections had to be made based on information gained during this case study. The corrections are as follows:

- $\quad-2$ points, water heater was less efficient than originally assumed;

- -1 point, the refrigerator was less efficient than originally assumed;

- -5 points, the $\%$ of basement wall was too high;

- $\quad+6$ points, cooling was not given credit originally

- $\quad+14$ points, ducts were not test during initial audit but were tested during case study inspection

The total of these adjustments is +12 points resulting in a SmartRegs score of 87 (HERS Index of 155 points). Because the minimum allowable score is 100 points, the owner will have to improve the property by 2019 in order to maintain the rental permit required by the City of Boulder.

Insulation improvements to this home would be difficult in most areas, including the attic. There is no access to the knee wall areas on the 2 nd floor, so insulating the sloped sections of the attic and the knee walls would not be possible without making several new access hatches. Another problem with insulating the attic is the presence of the knob and tube wiring, which should be replaced with new wiring before any additional insulation is installed.

Because this home is historic and has brick walls on the 1st floor, improvements to the exterior walls from the outside are not usually a viable option. In addition to this, the interior finish is lath and plaster which makes insulating walls

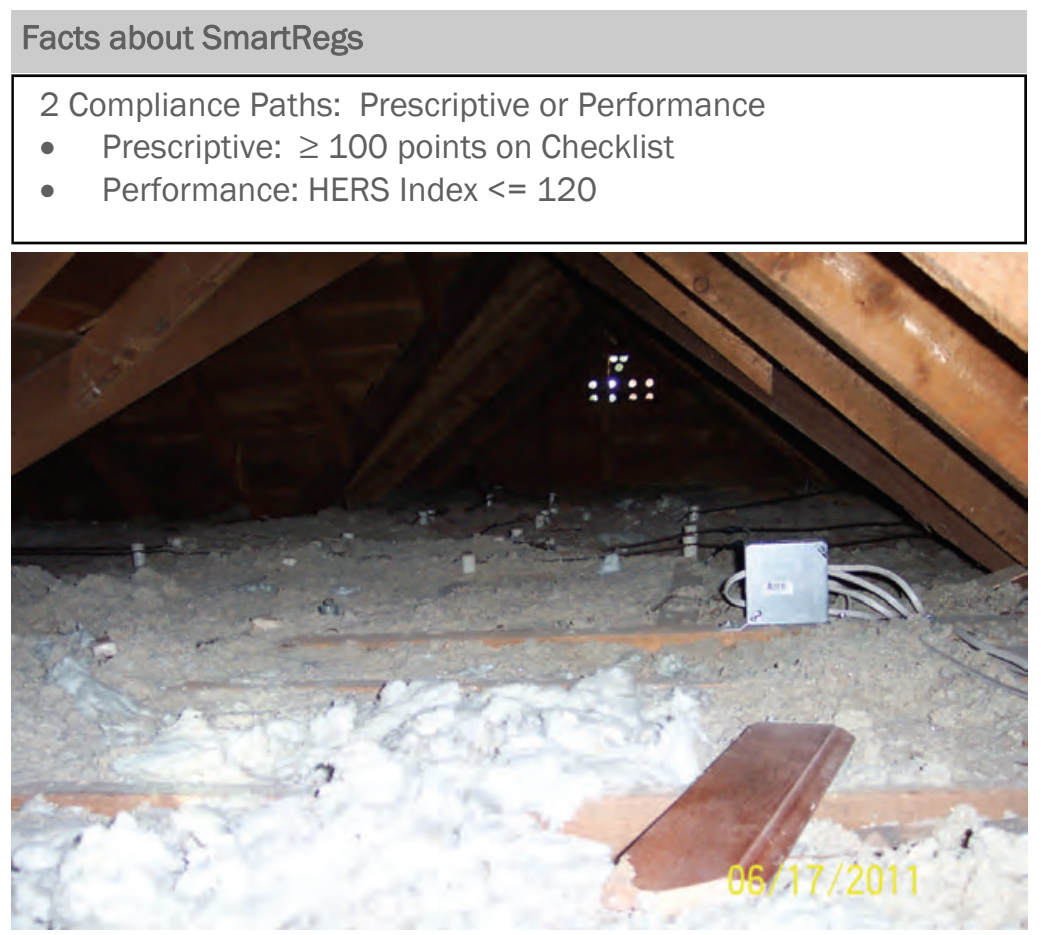

Attic is only insulated to $\mathbf{R - 1 0}$ and contains knob and tube wiring.

from the inside extremely difficult, messy and destructive.

Insulating the basement/crawl is not even a very viable option due to the amount of personal property currently being stored there.

The easiest upgrade option to bring this home into compliance would be to add storm windows to all the windows in the home. Although expensive, these would have a significant impact on the energy use of the home and on the comfort of the occupants. On historic properties, adding storm windows gains the owner 13 points. This would bring the SmartRegs score up to 100 for this property and results in a HERS Index of 144 points.

There could be several reasons why the improved case does not achieve a HERS Index of 120 , but scores 100 or more points on the SmartRegs checklist. For this home, it is anticipated that this discrepancy comes from the fact that the ceiling is getting full credit for being insulated to R-19, when it is really a combination of about $\mathrm{R}-10$ on the flat sections and R-O on the sloped (program administrators intend to correct this in the future). Also, storm windows on historic homes receive more than twice the points as window with a similar efficiency on a non-historic home. This is to ease some of the burden on the owners, because improving historic properties is usually so difficult and costly. If these two components are upgraded to the actual levels on the checklist for which they are being given points-R-19 attic and U-0.35 windows-the resulting HERS Index is 125 , very close to the intended threshold. www.swinter.com

50 Washington St. 6th FI, Norwalk, CT 06854 307 7th Ave. Ste. 1701, New York, NY 10001

1112 16th St., NW Ste. 240, Washington, DC 20036 tel 203-857-0200 fax 203-852-0741 tel 212-564-5800 fax 212-741-8673 tel 202-628-6100 fax 202-393-5043 


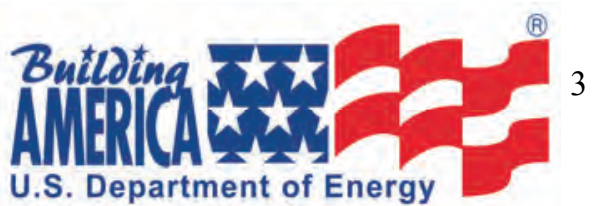

\section{Cold Climate Region: Case Study \#4 Utility Bill Analysis}

\section{Boulder, CO}

SmartRegs requirements were adopted to meet the city's sustainability objectives including environmental health, economic vitality and social equity. According to current statistics, rental properties comprise approximately 50 percent of Boulder's housing stock ${ }^{1}$. Therefore, by requiring property owners to upgrade rental properties, the SmartRegs program aids in advancing Boulder's community sustainability objectives, and will hopefully result in lower energy bills for tenants.

Predicted monthly utility bills for this property as it existed at the time of the initial inspection are displayed in the graph to the right. REM/Rate predicts an annual utility bill of $\$ 2,672$ : about $50 \%, \$ 1,281$, is attributed to heating.

Installing storm windows (HERS index of 144) results in predicted annual utility bill savings for the occupants of about $\$ 138$ per year.

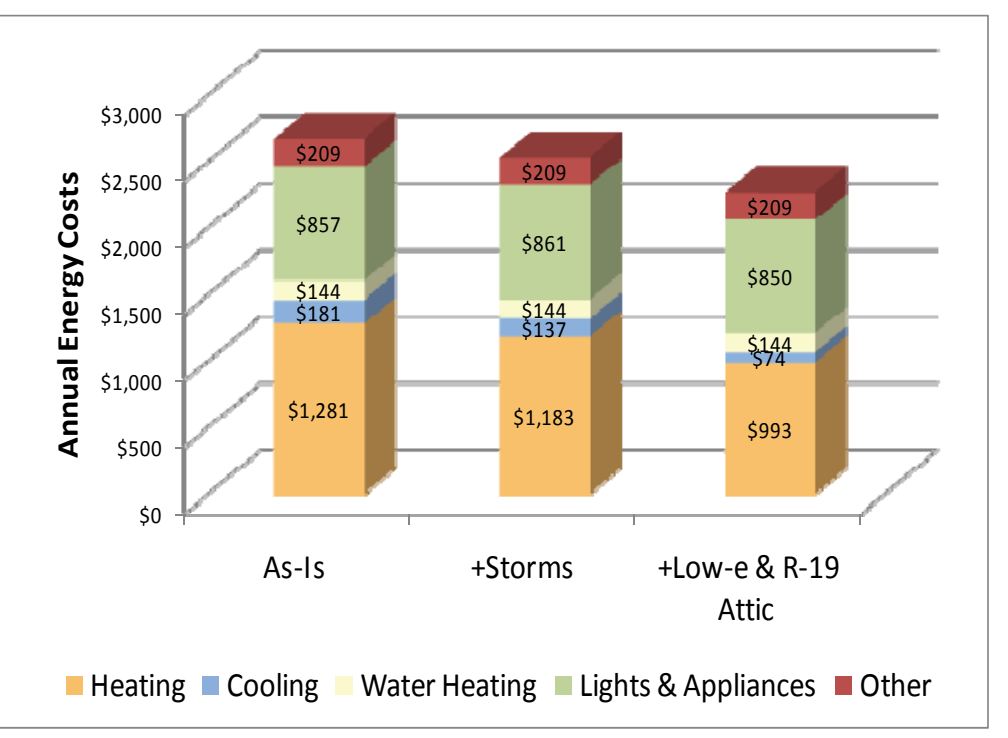

Predicted utility bills from REM/Rate.

Predicted emissions reductions range from 4 to $7 \%$. Total emissions are displayed in the graph to the right.

If efficiencies of the windows and attic were actually brought to the levels for which they are being (or would be, in the case of the windows) given credit on the SmartRegs checklist, annual savings increase to about $\$ 400$ per year, and emissions reductions range from 11 to $16 \%$ over the levels currently predicted for this property.

To better analyze programs like SmartRegs, comparisons to actual utility bills are critical. Unfortunately, obtaining utility bills from major providers has been and remains incredibly difficult, even with signed consent forms from homeowners or renters. While this is not necessarily a barrier to program implementation, it is a huge barrier to improving these programs and ensuring that the upgrades being recommended are effective from an energy reduction and a cost-effectiveness standpoint. Removing this barrier is essential in meeting long term program goals.

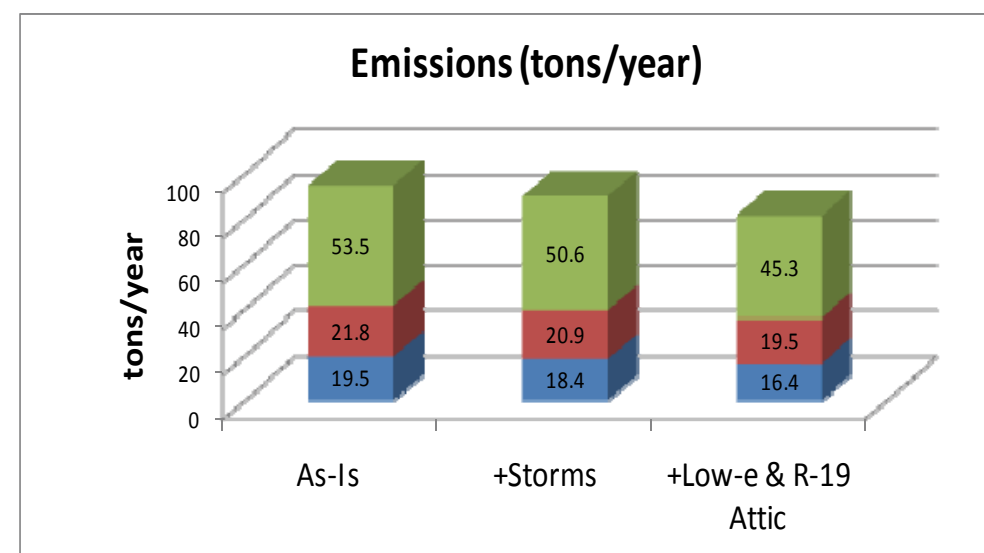

- Carbon Dioxide (CO2) - Sulfur Dioxide(SO2) $\quad$ Nitrogen Oxides (NOx)

Predicted $\mathrm{NO}_{x}, \mathrm{SO}_{2}$, and $\mathrm{CO}_{2}$ emissions from REM/Rate.

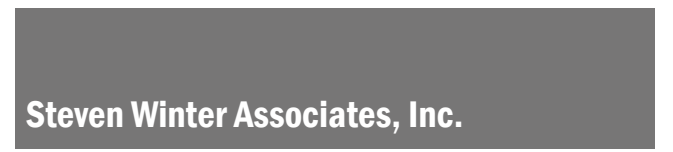

wwW.swinter.com

50 Washington St. 6th FI, Norwalk, CT 06854

307 7th Ave. Ste. 1701, New York, NY 10001

1112 16th St., NW Ste. 240, Washington, DC 20036 tel 203-857-0200 fax 203-852-0741 tel 212-564-5800 fax 212-741-8673 tel 202-628-6100 fax 202-393-5043 


\section{Boulder, CO}

The property owner was interviewed to determine her feelings and concerns about Boulder's new SmartRegs ordinance. A summary of her opinions and suggestions for improvements are below.

Q: Why did you decide to participate now and not wait till later in the process?

A: The owner sees herself as a perfectionist and is information driven. She is also a real estate broker and feels compliance will affect property value because buyers will look for it. She argues that landlords musts comply with these new regulations, so they might as well do it sooner rather than later. She also believes improving the efficiency of her properties is the right thing to do for the environment.

\section{Q: How long has the owner owned this property?}

A: 8 years. The owner bought this property as a rental, but is currently living in it while remodeling.

Q: Are you educating the occupants about what and why renovations are taking place and how it will benefit them?

A: Yes, the owner tries to raise the consciousness of the renters. She has 13 other rentals in all, some out of state.

\section{Q: What's the vacancy rate for your property?}

A: There are no problems with vacancy in Boulder.

Q: What is your normal maintenance routine - i.e., every few months, once a year, on occupant turn over?

A: This landlord provides occupants with enough furnace filters for a monthly change for the entire year. On occupant turnover she cleans, repairs things, reseals baths, and replaces all light bulbs.

\section{Q: What would you like other property owners to know?}

A: This owner believes that information is power; that if you don't know what is wrong or what is required, you can't fix it. She feels that other property owners have nothing to lose by having the inspection, since they have to comply anyway. The landlord feels it's the right thing to do, otherwise, you're wasting resources.

Steven Winter Associates, Inc. is the lead for the Department of Energy's Building America team called the Consortium for Advanced Residential Buildings (CARB).

CARB would like to thank Populus, LLC , a sustainable design consulting firm and the program administrator for the City of Boulder's SmartRegs program, for their expertise, time and assistance in creating these case studies.

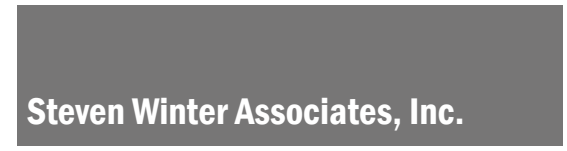

Steven Winter Associates, Inc. www.swinter.com

50 Washington St. 6th FI, Norwalk, CT 06854

307 7th Ave. Ste. 1701, New York, NY 10001

1112 16th St., NW Ste. 240, Washington, DC 20036 tel 203-857-0200 fax 203-852-0741 tel 212-564-5800 fax 212-741-8673 tel 202-628-6100 fax 202-393-5043 


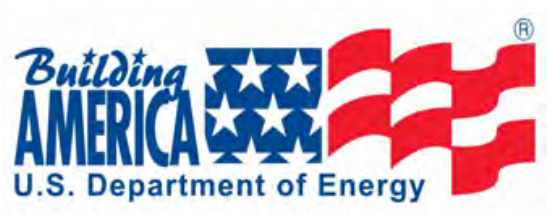

\section{Cold Climate Region: Case Study \#5 City of Boulder, SmartRegs Ordinance Low-Rise Multi-Family, 1960's Vintage}

\begin{tabular}{ll} 
Boulder, CO & \\
\hline Program & SmartRegs Ordinance \\
Location: & Boulder, Colorado \\
Building Type: & Low-Rise Multi-Family \\
Building Size: & $35,000+\mathrm{ft}^{2}$ living space \\
Foundation: & Slab-on-grade \\
Configuration: & 3 Stories, 69 Units, \\
SWA Contact: & Lois Arena \\
\hline
\end{tabular}

Built in 1966 , this $35,000+\mathrm{ft}^{2}$ apartment building was constructed on a slab-on-grade foundation with a flat, unvented roof. Due to height restrictions in the City of Boulder, most buildings, including multifamily buildings, are 3 stories or less in height. This 69 unit apartment complex fits that description.

The configuration of this building is somewhat unique in that it has a center courtyard for the residents' use. This configuration, sort of a square doughnut, results in at least 2 exterior walls for each apartment.

Efficiency levels in this property were consistent with its year and type of construction (see table at right). The apartments are heated with hot water baseboard radiators that are fed from two gas-fired central boilers.

These boilers also provide the domestic hot water for the occupants. Each boiler heats 2-119 gallon indirect hot water storage tanks to meet the daily hot water needs of the residents.

Since no nameplate information could be obtained from these boilers, the efficiencies were assumed to be 65 AFUE. These values are based on age and RESNET's Home Energy Rating System (HERS) standards, Table 303.7.1(3) Default Values for Mechanical System Efficiencies. The water heating efficiency is based on this AFUE and then reduced slightly to account for standby losses from the tanks.

Of the 69 apartments, 5 offer 2 bedrooms while the rest are 1 bedroom units. Apartment sizes are 470, 600 and $800 \mathrm{ft}^{2}$, the majority (56) of which are the smaller $470 \mathrm{ft}^{2}$ apartments. Other than the outdoor courtyard, common spaces are limited to a small laundry room and a couple of entryways.

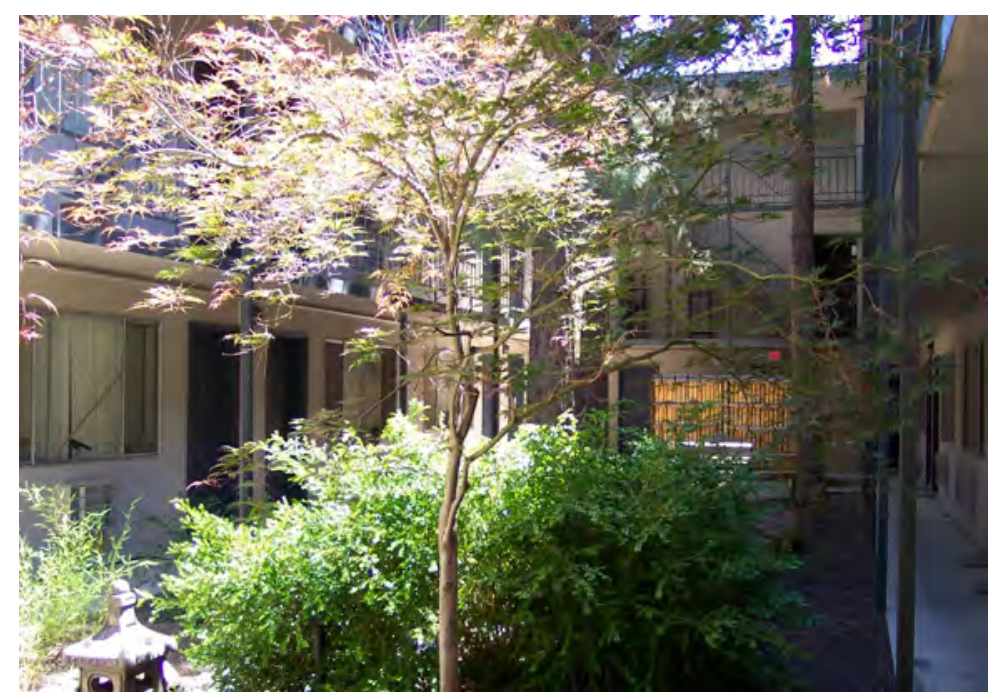

This 3-story, multi-family apartment building in Boulder, CO offers a central courtyard for tenant use.

\section{Energy Efficient Features \\ Roof: R-19 batts, unvented \\ Walls: R-11 \\ Windows: Single metal \\ Foundation: Slab-on-grade, R-O}

Heating: Central boilers (2), natural gas, 65 AFUE

Cooling: $\quad$ Window Units, SEER 8

Hot Water: Indirect tank off boiler, $0.60 \mathrm{EF}$

Air Leakage: $9.7 \mathrm{ACH} 50$ pascals, $0.52 \mathrm{ACHn}$

\section{Additional SmartRegs Features \\ None}

SmartRegs Checklist Score: from 92 to 104 points (Score must be $\geq 100$ points)

\section{HERS Index: from 112 to 128}

*100 points on the SmartRegs checklist should approximately equate to a HERS index of 120 .

Steven Winter Associates, Inc. is the lead for the Department of Energy's Building America team called the Consortium for Advanced Residential Buildings (CARB).

CARB would like to thank Populus, LLC, a sustainable design consulting firm and the program administrator for the City of Boulder's SmartRegs program, for their expertise, time and assistance in creating these case studies.

Steven Winter Associates, Inc.

www.swinter.com

50 Washington St. 6th FI, Norwalk, CT 06854 307 7th Ave. Ste. 1701, New York, NY 10001

1112 16th St., NW Ste. 240, Washington, DC 20036 tel 203-857-0200 fax 203-852-0741 tel 212-564-5800 fax 212-741-8673 tel 202-628-6100 fax 202-393-5043 


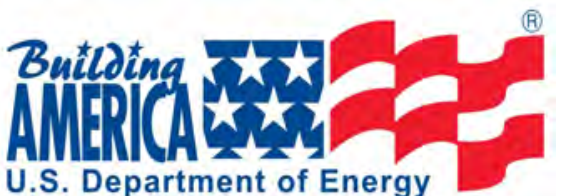

\section{Boulder, CO}

The manager of this property opted to use the prescriptive method of compliance and have the auditor fill out a checklist rather than perform energy modeling to determine if the property was in compliance. The checklist is quicker than modeling, provides answers right on site and does not require the additional time and expense of duct leakage testing. If compliance can be gained without modeling, the checklist is a more economical option.

Each apartment will be scored individually in the SmartRegs program to account for floor plan configuration differences. Differences in layout can result in different exposed wall areas, which in turn, can affect the SmartRegs score. Also depending on which level the apartment is located on, the unit may or may not have exposed ceilings or floors (slab). For example, a corner unit on the 1st floor will generally have a lower SmartRegs score than a center unit on the 2nd floor, because that second floor unit will have less wall exposed to the outside and will have neither a floor nor a ceiling exposed to the outside. These are both examples where the 2nd floor unit will gain more points than the 1 st floor unit.

The following table lists the scores for a center unit and a corner unit on each floor of the building.

\begin{tabular}{|cccc|}
\hline & \multicolumn{3}{c|}{ As-Is SmartRegs Scores } \\
& 1st Floor & 2nd Floor & 3rd Floor \\
Center & 95 & 104 & 101 \\
Corner & 92 & 101 & 98 \\
\hline
\end{tabular}

Because the minimum allowable score is 100 points, the property owner will have to improve the property by 2019 in order to maintain the rental permit required by the City of Boulder.

Based on the worse case scenario of 92 points for a 1st floor corner unit, 8 additional points would be needed to meet the SmartRegs threshold. Considering that the building is already getting substantial points for its walls, roof and infiltration, the areas of greatest opportunity are the windows and the heating system.
Facts about SmartRegs

2 Compliance Paths: Prescriptive or Performance

- Prescriptive: $100 \geq$ points on Checklist

- Performance: HERS Index $\leq 120$

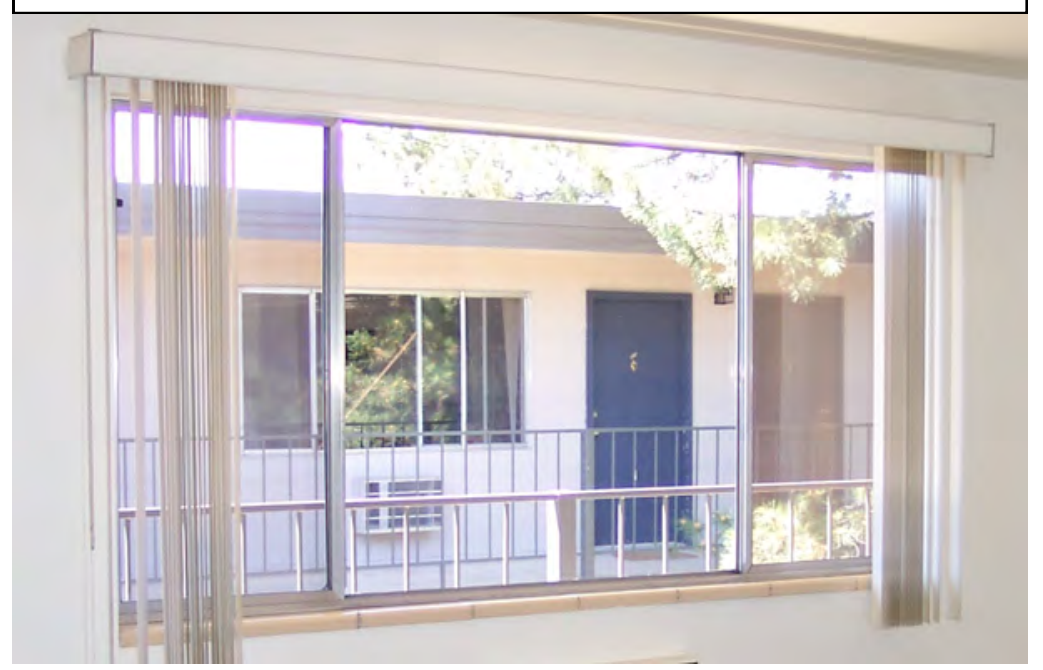

All the windows in this apartment complex are single pane metal windows.

This owner has chosen to replace all the single pane metal windows with low-e, vinyl windows with efficiencies of U-0.29. This upgrade gains 14 points on the SmartRegs checklist. When applied to all the as-is scores, all units come into compliance as can be seen in the following table.

\begin{tabular}{|cccc|}
\hline \multicolumn{4}{|c|}{ SmartRegs w/ New Windows $($ U-0.29) } \\
& 1st Floor & 2nd Floor & 3rd Floor \\
Center & 109 & 118 & 115 \\
Corner & 106 & 115 & 112 \\
\hline
\end{tabular}

For purposes of this case study, the small, center apartments were modeled using REM/Rate, a simulation program used to analyze the energy use of residential buildings. Small, center units were chosen because this is the configuration of the majority of the apartments in this building. The HERS Indices for this property as-is ranged from 112 for the 2nd floor center unit to 128 for the 1st floor center unit, showing very good agreement with the goals of program creators and administrators:

\section{0 points on the SmartRegs checklist should approximately equate to a HERS index of 120 points.}

After the windows are upgraded, the HERS Indices for the center units on all three floors fall at or below 106. www.swinter.com

50 Washington St. 6th FI, Norwalk, CT 06854 307 7th Ave. Ste. 1701, New York, NY 10001

1112 16th St., NW Ste. 240, Washington, DC 20036 tel 203-857-0200 fax 203-852-0741 tel 212-564-5800 fax 212-741-8673 tel 202-628-6100 fax 202-393-5043 


\section{Boulder, CO}

SmartRegs requirements were adopted to meet the city's sustainability objectives including environmental health, economic vitality and social equity. According to current statistics, rental properties comprise approximately 50 percent of Boulder's housing stock ${ }^{1}$. Therefore, by requiring property owners to upgrade rental properties, the SmartRegs program aids in advancing Boulder's community sustainability objectives, and will hopefully result in lower energy bills for tenants.

Predicted monthly utility bills for this property as it existed at the time of the initial inspection are displayed in the graphs to the right. The top graph shows the predicted annual utility bills for all 69 apartments. The bottom graph shows the annual bills for one 1st floor, center unit. Modeling this building either way-as one entire building or individual units-predicts an energy savings of just under \$80 per apartment per year after the metal windows are replaced with the low-e vinyl windows (U-0.29).

Compared to the single family case studies conducted, the majority of the predicted energy bills for this building are associated with the lights and appliances. This is understandable considering that many of the surfaces in each apartment border another apartment, therefore, little heat is lost. On a square foot basis, multi-family homes and apartments use much less energy for heating and cooling given the same efficiency values and conditioned square footage of detached homes.

This is not to say that upgrades that reduce heating and cooling loads should be overlooked in multifamily buildings. It should just be noted that the same improvements that may have been costeffective on a detached home, won't necessarily be cost-effective on a multi-family unit of the same size.

To better analyze programs like SmartRegs, comparisons to actual utility bills are critical. Unfortunately, obtaining utility bills from major providers has been and remains incredibly difficult, even with signed consent forms from homeowners or renters.

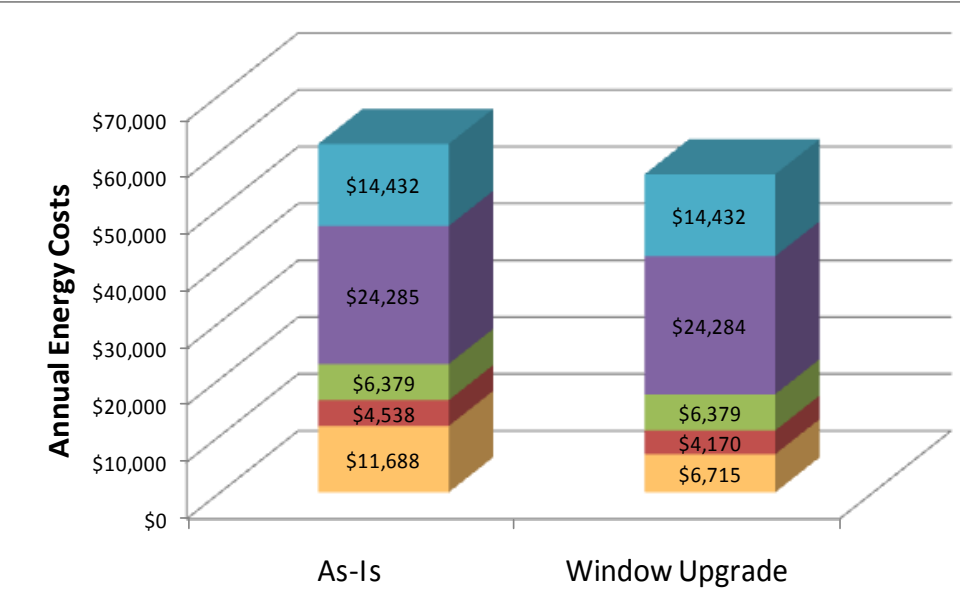

$\square$ Heating Cooling $\square$ Water Heating $\square$ Lights \& Appliances $\square$ Other

Predicted utility bills for all apartments from REM/Rate.

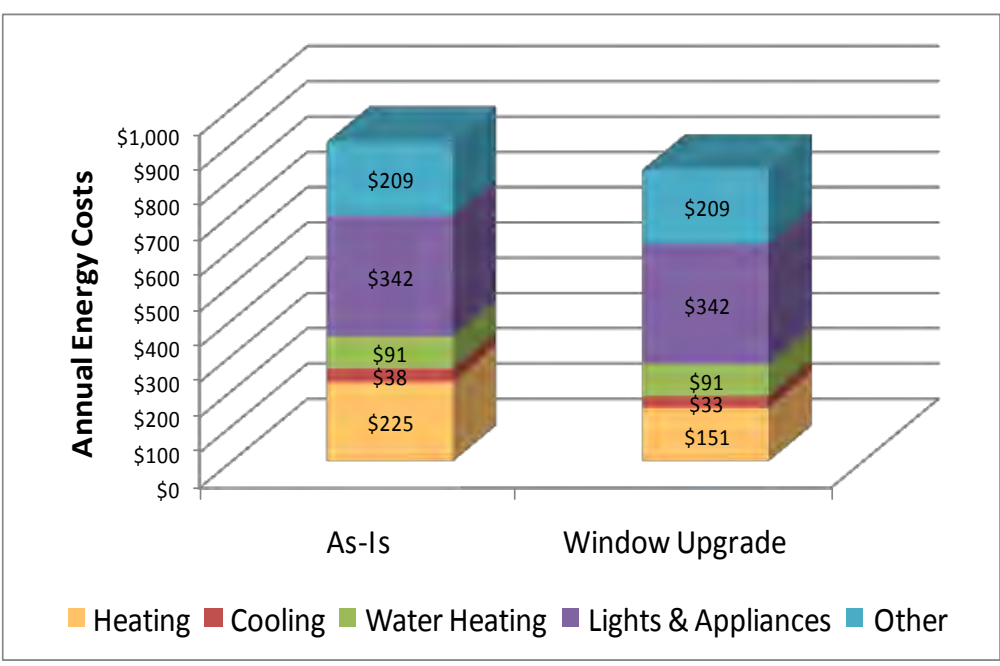

Predicted utility bills for one 1st floor, center unit.

While this is not necessarily a barrier to

12011 SmartRegs Handbook, City of Boulder

program implementation, it is a huge barrier to improving these programs and ensuring that the upgrades being recommended are effective from an energy reduction and a cost-effectiveness standpoint. Removing this barrier is essential in meeting long term program goals.

www.swinter.com

50 Washington St. 6th FI, Norwalk, CT 06854

307 th Ave. Ste. 1701, New York, NY 10001

1112 16th St., NW Ste. 240, Washington, DC 20036 tel 203-857-0200 fax 203-852-0741 tel $212-564-5800$ fax 212-741-8673 tel 202-628-6100 fax 202-393-5043 


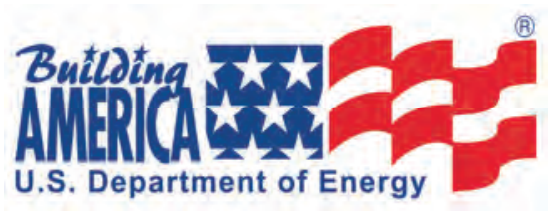

\section{Cold Climate Region Case Study \#6: 1036 12th Street City of Boulder, SmartRegs Ordinance Multi-Family, Early 1900's Vintage}

\begin{tabular}{ll} 
Boulder, CO & \\
\hline Program: & SmartRegs Ordinance \\
Location: & Boulder, Colorado \\
Building Type: & Multi-Family \\
Number of units: & 2 \\
Building Size: & $1033 \mathrm{ft}^{2}$ Upper $/ 285 \mathrm{ft}^{2}$ Lower \\
Foundation: & Basement/Crawlspace: Unconditioned \\
Configuration: & 3 bedrooms, 2 baths \\
SWA Contact: & Lois Arena \\
\hline
\end{tabular}

Due to their proximity to the University of Colorado, there are several older neighborhoods in Boulder that are dominated by rental properties. Many of these old, single family homes, such as this bungalow built in 1919, have been divided into more than one unit: this home has been divided into two rental units. The main level plus a loft area comprise one (upper unit), and a much smaller garden basement area (lower unit) comprises the other.

According to Boulder's SmartRegs requirements, each rental unit in a building must be tested and scored separately. Unusual layouts, common walls and floors, shared equipment, and occupant use of the space can make this quite challenging. Efficiency levels and testing results for each unit in this home are shown in the table at right. As can be seen in that table, the resulting SmartRegs scores and HERS Indices are quite different for each even though they are located in the same building.

It is common when rating multi-family buildings that some units will score better than others. Contributing factors include whether the unit is on the bottom, middle or top floor of the building, the amount of exposed surface to outside, and differences in lighting and appliances in each space. Differences in the HERS Index can also be the result of the affects of solar exposure and the amount of window area.

The lower unit in this building, being partially below grade and substantially bordered by conditioned space of the upper unit (entire ceiling and 50\% of the walls) scores much higher on the SmartRegs checklist than the upper unit. Of the 51 point difference between the two units, 43 points come from the fact that the lower unit's ceiling and $50 \%$ of its walls border the upper unit.

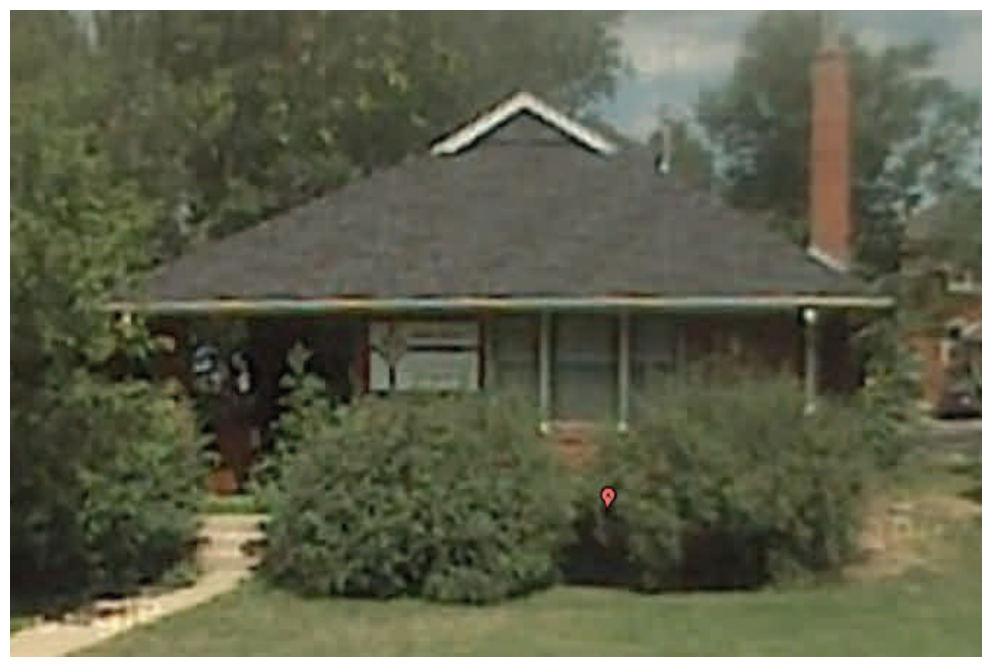

This home has been divided into two rental units. While the lower unit complies with Boulder's SmartRegs ordinance, improvements must be made to the upper unit .

\section{Energy Efficient Features \\ Attic: $\quad$ R-11 blown \& batts \\ Walls: Uninsulated brick \\ Windows: Predominantly single pane wood \\ Foundation: Crawlspace ceiling R-19, Basement R-O \\ Heating: $\quad$ Central system - forced air, natural gas, 80 AFUE, in unconditioned basement \\ Cooling: None \\ Ductwork: Uninsulated \& in unconditioned space \\ Hot Water: Atmospheric, natural gas, unconditioned space, $0.59 \mathrm{EF}$ \\ Air Leakage: Upper: $31.4 \mathrm{ACH}$ 50 pascals, 2.12 ACHn Lower: 43.5 ACH@50 pascals, 1.96 ACHn}

\section{Additional SmartRegs Features}

Low-flow faucets and showerheads, programmable thermostat

\section{SmartRegs Checklist Score*: 59 points Upper 110 points Lower}

(The final score must be $\geq 100$ )

\section{HERS Index: 181 Upper/128 Lower}

*100 points on the SmartRegs checklist should approximately equate to a HERS index of 120.
Steven Winter Associates, Inc.
wWw.swinter.com

61 Washington St. 6th FI, Norwalk, CT 06854 307 7th Ave. Ste. 1701, New York, NY 10001 1112 16th St., NW Ste. 240, Washington, DC 20036 tel 203-857-0200 fax 203-852-0741 tel 212-564-5800 fax 212-741-8673 tel 202-628-6100 fax 202-393-5043 


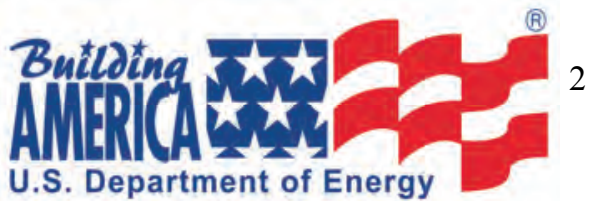

\section{Boulder, CO}

The minimum allowable score when using the prescriptive method for compliance with Boulder's SmartRegs ordinance is 100 points. The lower unit of this property scores 110 points, but the upper only scores 59, therefore, the owner will have to improve the upper unit of this property by 2019 in order to maintain their rental license.

When developing the SmartRegs checklist, program creators intended that 100 points should approximately equate to a HERS index of 120 . Given this assumption, the lower unit should have a HERS Index less than 120, and the upper should have an index well above that.

To validate this assumption, SWA modeled both units in this home using REM/Rate, a simulation program used to analyze the energy use of residential buildings. As anticipated, the upper unit received a HERS Index of 181, much higher than 120 points, but the lower unit only received an index of 128 even though the SmartRegs score was 110.

There could be several reasons why the HERS Index is higher than 120 , but according to the SmartRegs prescriptive checklist, the unit is in compliance. A few issues that affect the HERS index but not the SmartRegs score include:

- $\quad$ Smaller homes tend to get higher HERS Indices because the surface area to volume ratios are higher than for larger homes.

- $\quad$ The higher the window to wall area ratio the more heat loss from the home. SmartRegs doesn't measure areas, just efficiencies of the components.

- Orientation is not considered in SmartRegs, but will affect a HERS index due to its impact on solar gain.

- $\quad$ SmartRegs uses steps in efficiency levels and associates points with each step (table at right) vs. using the actual efficiency as is done in a HERS model.

- Definitions of conditioned vs. unconditioned basements are slightly different between the two methods.

\section{Facts about SmartRegs}

2 Compliance Paths: Prescriptive or Performance

- Prescriptive: $\geq 100$ points on Checklist

- Performance: HERS Index <= 120

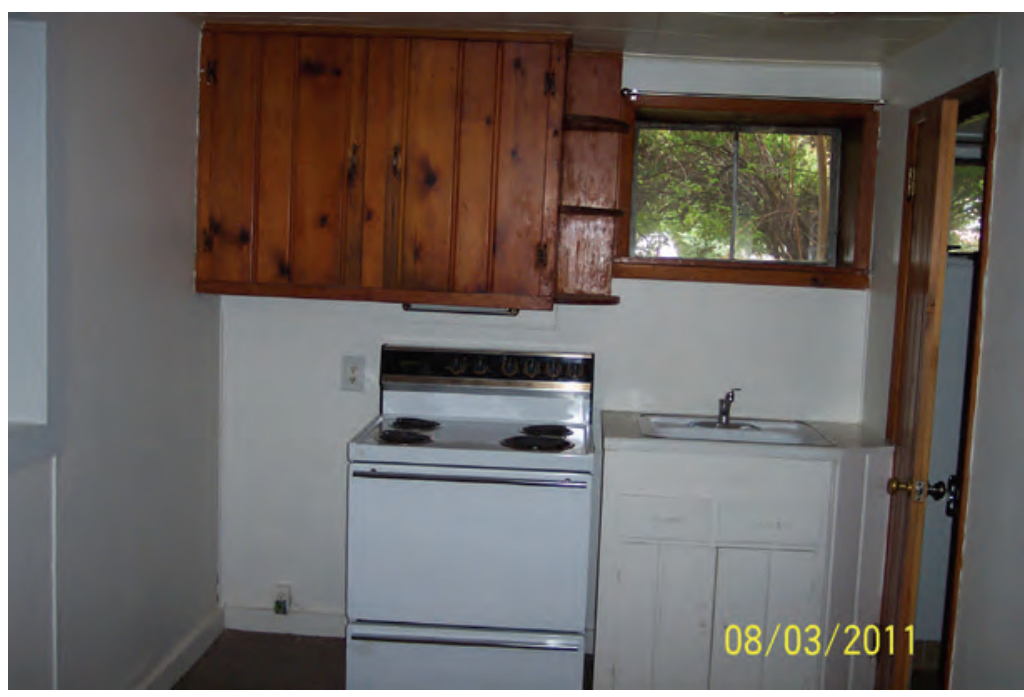

Garden Level Lower Apartment

\begin{tabular}{|lcccc|} 
ATTIC & \multicolumn{2}{c}{ Base: } & \multicolumn{2}{c|}{ Final: } \\
\hline \multicolumn{1}{|c}{ TYPE } & $\mathbf{2 5 \%}$ & $\mathbf{5 0 \%}$ & $\mathbf{7 5 \%}$ & $\mathbf{1 0 0 \%}$ \\
\hline No Insulation & 0 & 0 & 0 & 0 \\
\hline R-19 & 6 & 12 & 18 & 24 \\
\hline R-30 & 6 & 13 & 19 & 26 \\
\hline R-38 or Better & 7 & 13 & 20 & 26 \\
\hline Shared Ceilings & 7 & 14 & 20 & 27 \\
\hline
\end{tabular}

\section{Attic Section of SmartRegs Checklist}

Therefore, although 100 on the checklist is intended to approximately equate to a HERS Index of 120 , it can sometimes be higher or lower than that.

In the case of this lower unit, it is in fact only $285 \mathrm{ft} 2$ : a very small space. It also receives very little solar gain because most of the windows are highly shaded by neighboring property and vegetation. And finally, although the basement of the upper unit is considered conditioned according to SmartRegs standards, it is modeled as unconditioned according to HERS standards.
Steven Winter Associates, Inc. tel 203-857-0200 fax 203-852-0741 tel 212-564-5800 fax 212-741-8673 tel 202-628-6100 fax 202-393-5043 


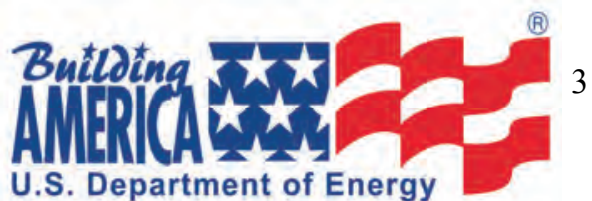

\section{Boulder, CO}

Various improvement options for this property owner include:

- Bsmt/Crawlspace (50\% of unit's footprint): insulating the walls to R-19, air sealing and installing a vapor barrier on the crawlspace floor (6 points-includes points for bringing ductwork into conditioned space);

- Insulating $75 \%$ of the attic to R-30 (20 points-25\% is vaulted and cannot be brought to R-30);

- Replacing the water heater with an instantaneous, 82 EF model (5 points);

- Installing an ENERGY STAR refrigerator <= $350 \mathrm{kWh} / \mathrm{yr}$ (4 points);

- Install storm windows on all single-pane, wood windows (6 points);

- $\quad$ Reducing the air leakage to $0.75 \mathrm{ACHn}$ (4 points);

Package 1: The property owner is free to implement any combination of energy improvements as long as the final checklist score is at least 100. If all of the above improvements are implemented, the upper unit would score 104 points and results in a HERS Index of 115. The costs to implement all of the above improvements would probably exceed $\$ 10,000$.

Another option would be to install at least $1 \mathrm{~kW}$ of PV (photovoltaics) on the roof. This upgrade receives 44 points on the SmartRegs checklist, but can only be counted toward compliance if the home already scores 70 points or higher. Since the upper unit only scores a 59 in its current condition, efficiency improvements that increase the score by at least 11 points will have to be made first before the PV can be counted.

Package 2: The easiest improvement would be to insulate the flat ceilings to R-30 for 20 points, and then install $1 \mathrm{~kW}$ of PV for an additional 44 bringing the final SmartRegs score to 123. Costs for this option would be around $\$ 4000$.

While this combination of improvements results in compliance with the prescriptive path, the corresponding HERS Index is only 162. The impacts on utility bills, energy use and greenhouse gas production are addressed on the following page.

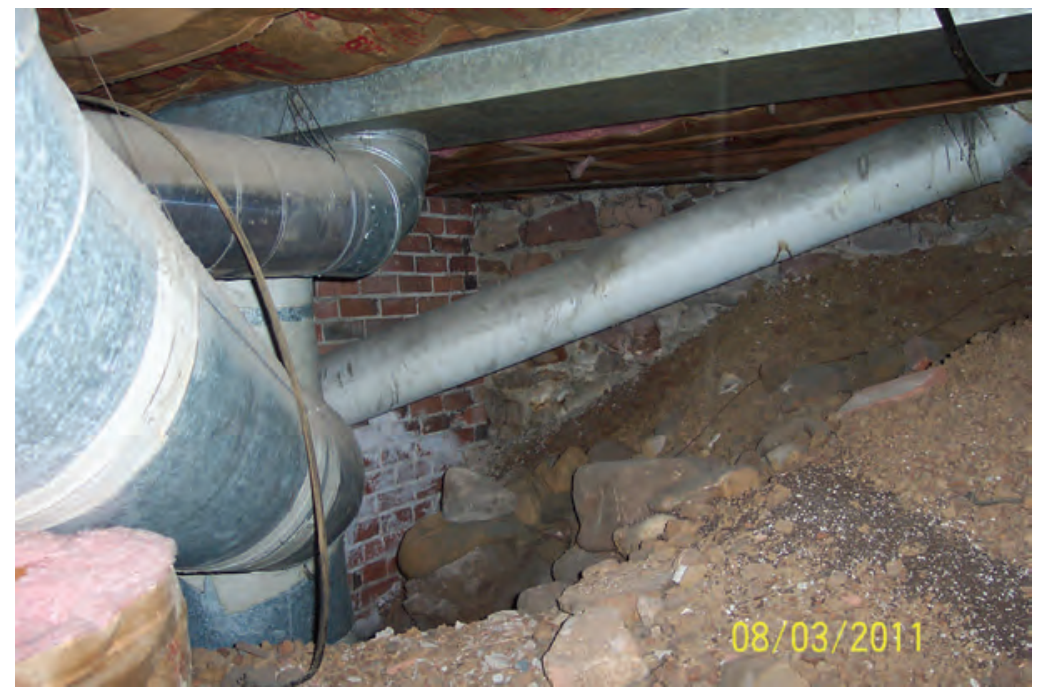

R-19 insulation is installed between the floor joists in the ceiling of this crawlspace but gets no credit on the SmartRegs checklist because heating ducts are present.

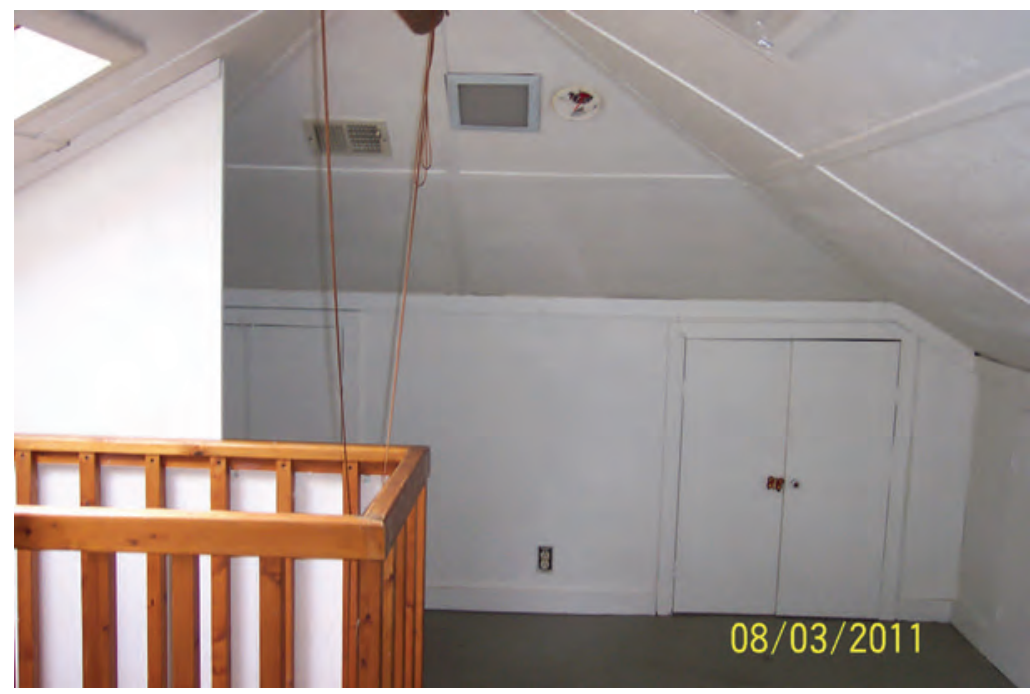

Attic is only insulated to R-11. Kneewall access hatches are extremely leaky.

SmartRegs Score and HERS Index for each Upgrade Package.

\begin{tabular}{|l|c|c|}
\hline \multicolumn{2}{|c|}{ Package 1 } & Package 2 \\
\hline Upgrade Item & $\begin{array}{c}\text { Attic \& Foundation Insulation, Storm } \\
\text { Windows, 0.75 ACHn, New Refridg., } \\
\text { Instant. Water Heater }\end{array}$ & Attic Insulation, PV \\
\hline $\begin{array}{l}\text { SmartRegs } \\
\text { Hers Index }\end{array}$ & 104 & 123 \\
\cline { 2 - 3 } & 115 & 162 \\
\hline
\end{tabular}

Steven Winter Associates, Inc.
wWw.swinter.com

61 Washington St. 6th FI, Norwalk, CT 06854 307 7th Ave. Ste. 1701, New York, NY 10001

1112 16th St., NW Ste. 240, Washington, DC 20036 tel 203-857-0200 fax 203-852-0741 tel 212-564-5800 fax 212-741-8673 tel 202-628-6100 fax 202-393-5043 


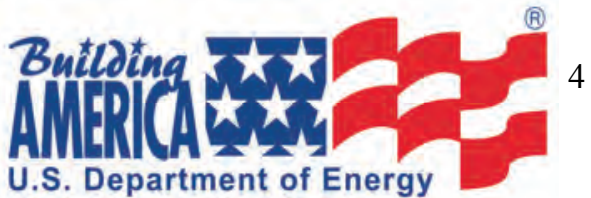

\section{Boulder, CO}

Predicted monthly utility bills for this property as it existed at the time of the initial inspection are displayed in the graph to the right. REM/Rate predicts an annual utility bill of $\$ 1,791$ : about $66 \%, \$ 1,179$, is attributed to heating. The first option package discussed on the previous page-insulating the foundation and attic, air sealing, storm windows, new water heater and refrigerator (HERS index of 115 )-results in predicted utility bill savings of 33\% or $\$ 589$ per year and a 38\% reduction in energy consumption (see table bottom right) The second improvement package-insulating the attic and in stalling $1 \mathrm{~kW}$ of PV (HERS Index of 162)-results in predicted utility bill savings of $10 \%$ or $\$ 184$ per year and a $7 \%$ reduction in energy consumption.

The predicted green house gas emissions for each of the three scenarios evaluated in this report are displayed in the figure to the right. When creating the SmartRegs checklist, developers weighted the points using a number of different parameters. A measure's impact on greenhouse gas reduction was one of those parameters. The result was: improvements that reduce electric use are more heavily weighted than those that reduce gas use. Here's why.

The amount of $\mathrm{CO}_{2}$ emitted per 1 MMBtu of energy produced from burning coal is almost twice that of natural gas ${ }^{1}$. When production and transmission losses from the power plant are factored in, emissions due to electricity generation increase by a factor of $3.3^{2}$. This is the difference between energy produced at the "source" (the power plant) and energy consumed at the "site" (the home). This means that emissions from electricity generation using coal are really a factor of six greater than those from burning natural gas to heat a home in Colorado's climate.

Therefore, even though Package \#2 saves fewer MMBtu's at the site than Package \#1 (7\% reduction vs. 38\%), it results in a bigger reduction in greenhouse gases per MMBtu saved (table at right) when energy use at the source is considered. This is why installing PV is weighted so heavily and gains 44 points on the SmartRegs checklist. Installing PV results in bigger reductions in greenhouse gases per MMBtu saved than measures that reduce natural gas use.
Reductions in Energy Use and Emissions
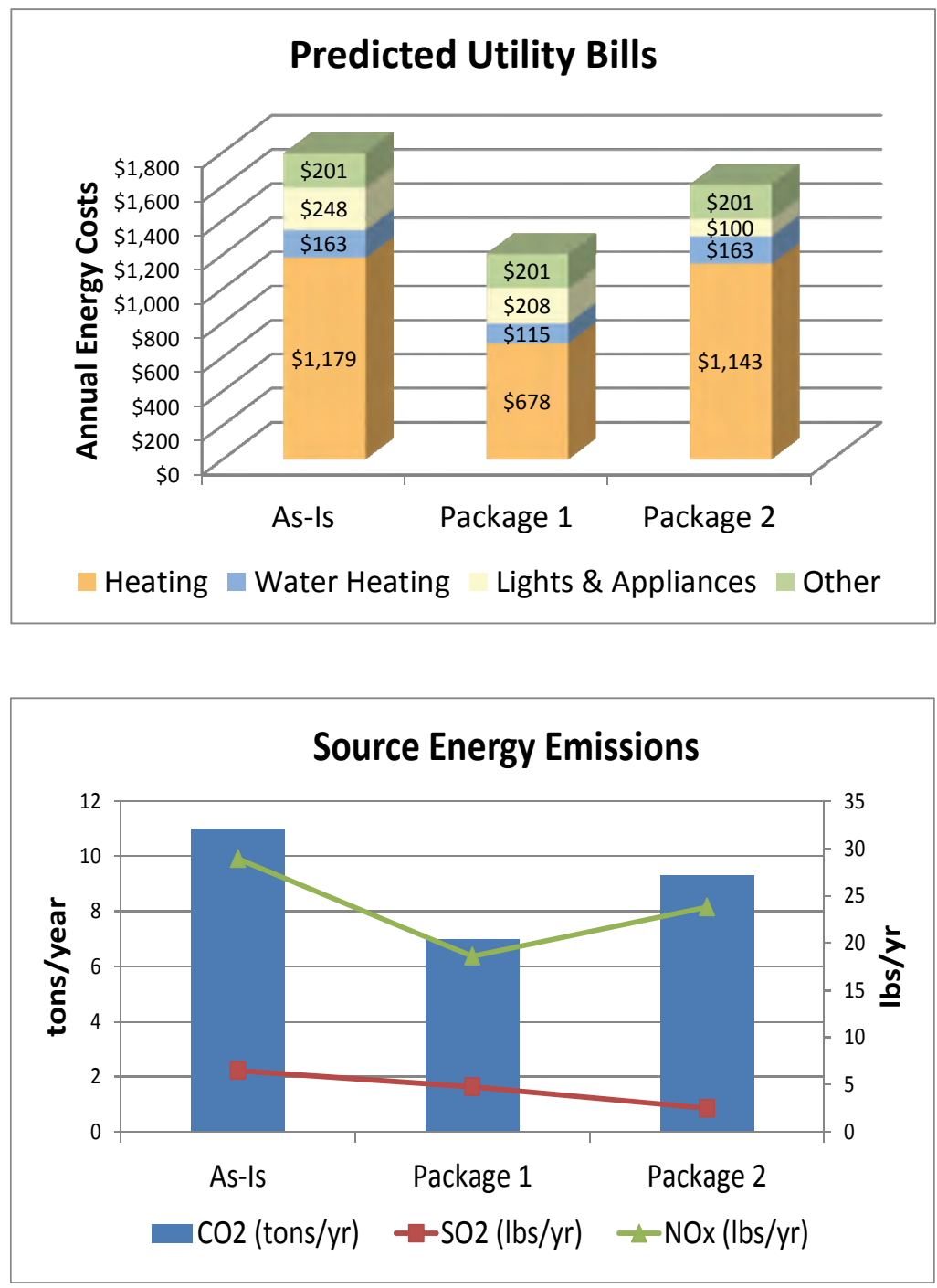

\begin{tabular}{|l|cc|}
\hline \multicolumn{3}{|c|}{ Reduction Compared to As-ls Case } \\
\hline Utility Bills & $33 \%$ & $10 \%$ \\
\hline Emmissions & $34 \%$ & $23 \%$ \\
\hline Annual Energy Consumption & $38 \%$ & $7 \%$ \\
\hline Tons of $\mathrm{CO}_{2} / \mathrm{MMBtu}$ Saved & 0.07 & 0.15 \\
\hline
\end{tabular}

${ }^{1}$ http://www.eia.gov/tools/faqs/faq.cfm?id $=74 \& t=11$

${ }^{2}$ http://www.energystar.gov/ia/business/evaluate_performance/site_source.pdf www.swinter.com

61 Washington St. 6th FI, Norwalk, CT 06854 307 7th Ave. Ste. 1701, New York, NY 10001

1112 16th St., NW Ste. 240, Washington, DC 20036 tel 203-857-0200 fax 203-852-0741 tel 212-564-5800 fax 212-741-8673 tel 202-628-6100 fax 202-393-5043 


\section{Boulder, $\mathrm{CO}$}

This property is owned by the foundation of a local church. One of the board members assisting with the management of the rental was interviewed to determine the board's feelings and concerns about Boulder's new Smart-

Regs ordinance. A summary of his opinions and suggestions for improvements are below.

Q. Why did you decide to participate now and not wait till later in the process?

A: The board of this foundation chose to participate now to take advantage of free inspections and to start the planning process in the case that improvements would need to be made.

\section{Q. How long has the owner owned this property?}

A: This property has been owned for approximately 15 years by a foundation for a local church. They own a total of 2 rental properties.

Q. Are you educating the occupants about what and why renovations are taking place and how it will benefit them?

A: There is no tenant education at this time. The church board is evaluating its improvement options and has yet to make any decisions.

\section{Q. What's the vacancy rate for your property?}

A: Like most other rental property owners in Boulder, these owners indicated that they have no problems with vacancy.

Q. What is your normal maintenance routine - i.e., every few months, once a year, on occupant turn over?

A: The foundation performs maintenance as necessary every 4 years upon their rental license renewal.

\section{Q. Concerns?}

A: The owner's biggest concern is the cost to improve the property when the land the house sits on is worth so much more than the house. The board feels that SmartRegs is disconnected from the point that the people paying the bills are not the people improving the house.

SmartRegs representatives explained that this is the purpose for the ordinance. That without it, rental property owners would not improve the energy efficiency of these units given that they are not paying the bills, and therefore, have no incentive to make any improvements to reduce energy consumption.

Steven Winter Associates, Inc. is the lead for the Department of Energy's Building America team called the Consortium for Advanced Residential Buildings (CARB).

CARB would like to thank Populus, LLC, a sustainable design consulting firm and the program administrator for the City of Boulder's SmartRegs program, for their expertise, time and assistance in creating these case studies. 


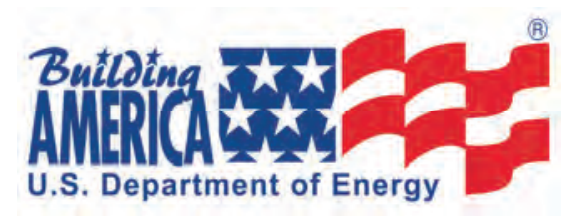

\section{Cold Climate Region Case Study \#7: 1172 Jay Street City of Boulder, SmartRegs Ordinance Multi-Family Low-Rise, 1950's Vintage}

\begin{tabular}{|ll|}
\hline Boulder, CO & \\
\hline Program & SmartRegs Ordinance \\
Location: & Boulder, Colorado \\
Building Type: & Multi-family, low-rise, \\
& Triplex \\
Units Analyzed: & 2 \\
Area/unit: & $763 \mathrm{ft}^{2}$ \\
Foundation: & Slab on grade \\
Configuration: & 2 bedrooms, 1 bath \\
SWA Contact: & Lois Arena \\
\hline
\end{tabular}

This 1950's rental property is located on "the hill" in Boulder, a popular destination for students moving into the area. From this neighborhood students are just a short bike ride from the University of Colorado and enjoy close proximity to restaurants, mass transit and hiking trails.

This building contains three rental units: 2 on the upper floor (which have identical floor plans) and one apartment on the lower level. At the time of this audit, only the upper left unit had been through a SmartRegs inspection. The owner felt that having one inspection was enough to: 1) get a sense of the worst-case SmartRegs score for this property, and 2) plan for improvements if necessary.

SWA was able to inspect both upper units. Efficiency levels and test results are listed in the table to the right. Based on those inspections it was determined that the upper right unit scored 82 points on the SmartRegs checklist while the left unit only scored 74 points.

During the initial SmartRegs inspection, the upper left apartment scored 85 points, but since that first inspection, a window air-conditioner $(\mathrm{A} / \mathrm{C})$ was installed by the occupant. Because the A/C was poorly installed, this measure also increased the air leakage of the unit. Finally, it appears that several compact fluorescent bulbs (CFL's) were replaced with incandescent bulbs. All of these measures resulted in a loss of points on the SmartRegs checklist.

Due to the changes made after the initial SmartRegs inspection, the upper left unit is the focus of this case study. The impacts of occupant behavior on the goals of the SmartRegs program are discussed in the following pages.

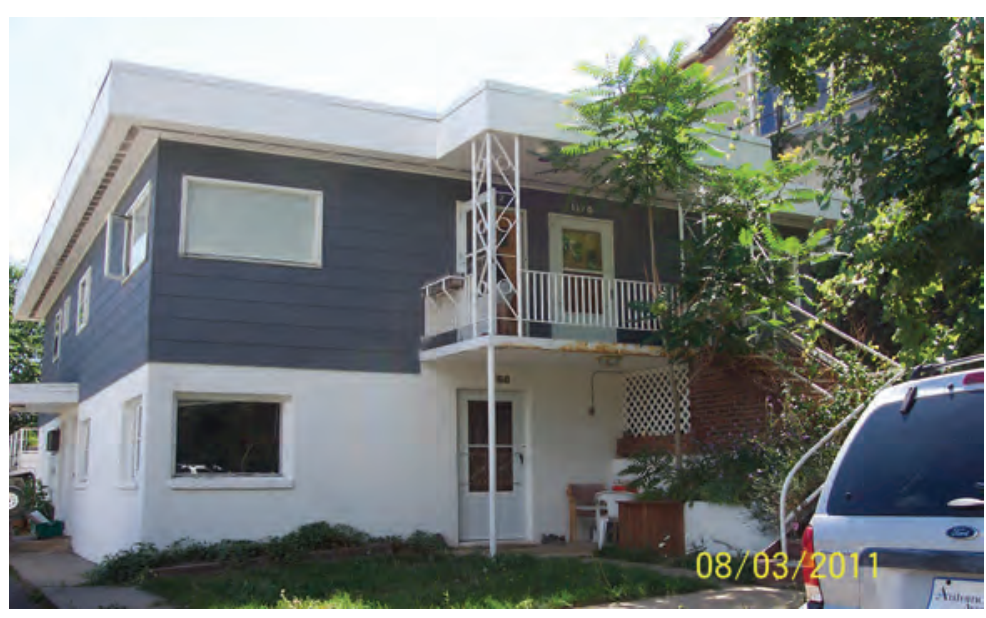

This apartment (upper left) initially scored 85 points on the

SmartRegs checklist. At the time of this audit, the score was reduced to 74 points due to the addition of a window airconditioning unit by the occupants.

\section{Energy Efficient Features \\ Attic: $\quad$ R-8 Blown Fiberglass insulation \\ Walls: R-11 Fiberglass batts \\ Windows: Combination of single wood, single wood with storm window \\ Foundation: Slab-on-grade \\ Heating: $\quad 60 \%$ AFUE natural gas boiler \\ Cooling: $\quad$ 10.8 EER window unit \\ Hot Water: $\quad 0.60 \mathrm{EF}$, natural gas, conditioned space, 50 gallons}

Air Leakage: 13.82 ACH@50 pascals, 0.75 ACHn

\section{Additional SmartRegs Features}

None.

\section{SmartRegs Checklist Score*: 74 points \\ (The final score must be $\geq 100$ )}

\section{HERS Index: 147}

*100 points on the SmartRegs checklist should approximately equate to a HERS index of 120 .

${ }^{* *}$ Original score of 85 was adjusted for post-occupancy changes, resulting in a SmartRegs score of 74.
Steven Winter Associates, Inc. www.swinter.com

61 Washington St. Norwalk, CT 06854

307 7th Ave. Ste. 1701, New York, NY 10001

1112 16th St., NW Ste. 240, Washington, DC 20036

tel 203-857-0200 fax 203-852-0741 tel 212-564-5800 fax 212-741-8673 tel 202-628-6100 fax 202-393-5043 


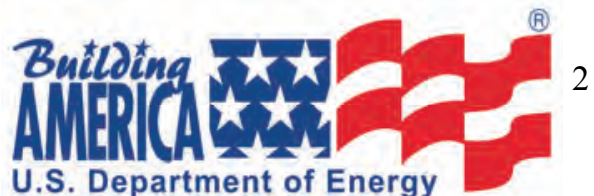

\section{Boulder, CO}

As has been quite common to date, the owner of this property opted to use the prescriptive method of compliance and have the auditor fill out a checklist rather than perform energy modeling to determine if the property was in compliance.

As noted earlier, the initial SmartRegs score for this unit was 85 points. With the addition of the $\mathrm{A} / \mathrm{C}$ and some incandescent light bulbs by the occupant, the score dropped to 74 . Because the minimum allowable score is 100 points, the owner will have to improve the property to maintain the rental permit required by the City of Boulder.

The property owner is free to implement any combination of energy improvements as long as the final checklist score is at least 100. There are several combinations that would bring this home into compliance Below are two options.

Package \#1: (+28 points)

- Replacing the boiler with one that is $90 \%$ efficient,

- Replacing the bulbs in all light fixtures with CFLs,

- $\quad$ Replace the refrigerator with a model $<=350$ kWh/yr.

This package results in a HERS Index of 105 and a SmartRegs score of 102.

Package \#2: (+44 points)

- $\quad$ Install $1 \mathrm{~kW}$ of photovoltaic-generated power. Package \#2 results in a HERS Index of 128 and a SmartRegs score of 118 .

Note that, while the installation of PV increases the SmartRegs score to 118 (well above compliance), the HERS Index only drops to 128 . The reason for this is that the SmartRegs program prioritizes improvements not only by energy savings but also by carbon reduction. Because the emissions from electricity generation are so much greater than those generated from heating a home with natural gas, any measure that reduces electrical consumption is weighted more heavily than one that reduces the heating demand. Thus, the credit a home receives for PV in the SmartRegs program is more than is applied through the HERS rating, which only looks at consumption, not emissions.

Cold Climate Region: Case Study \#7 SmartRegs Compliance

Facts about SmartRegs

2 Compliance Paths: Prescriptive or Performance

- Prescriptive: $\geq 100$ points on Checklist

- Performance: HERS Index <= 120

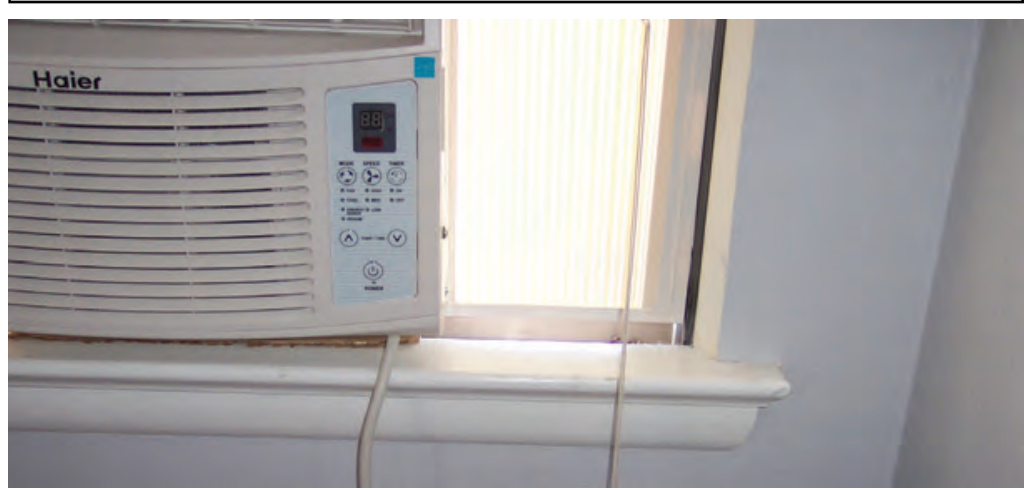

A window air-conditioner was installed after the initial SmartRegs inspection. A large air-gap around the $A / C$ resulted in a significant increase in the overall infiltration rate of the apartment.

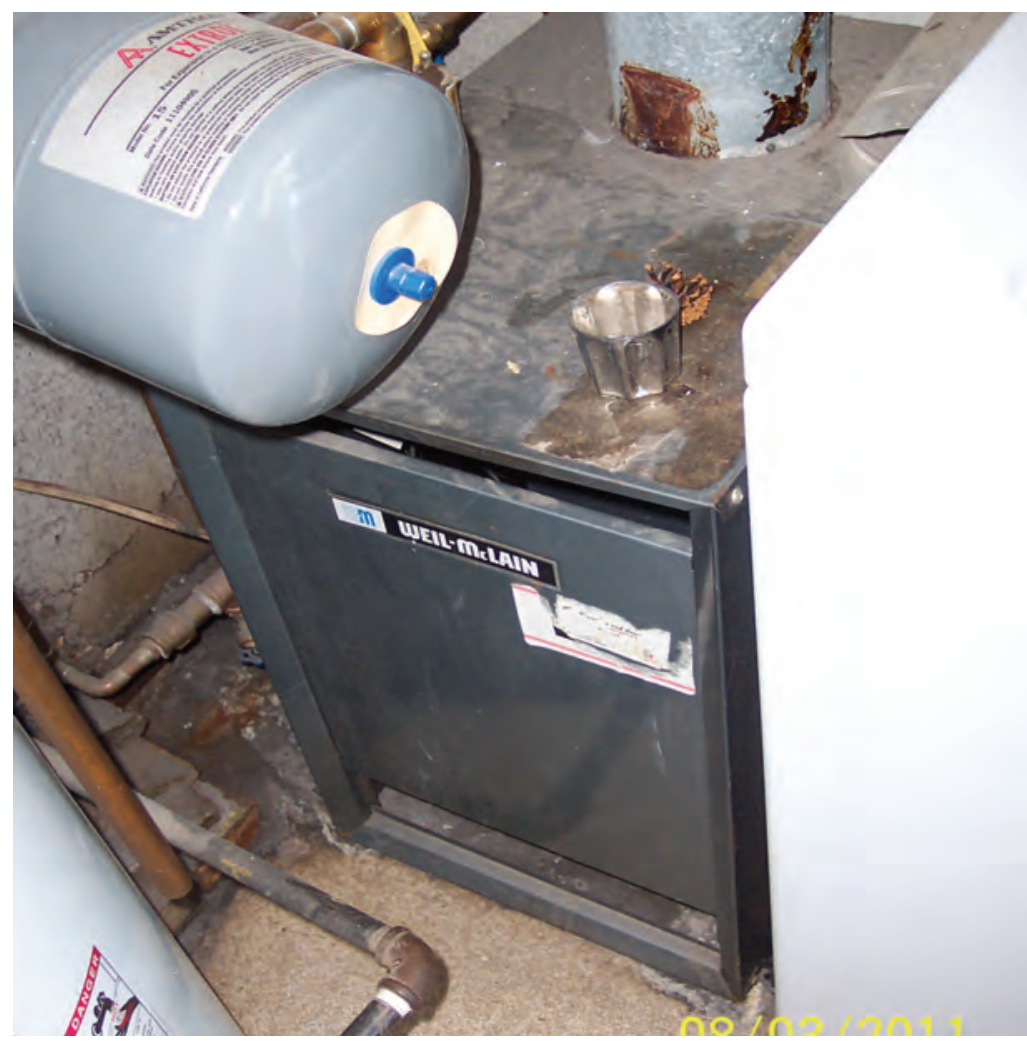

Replacing this $60 \%$ efficient gas boiler with a $90 \%$ efficient unit gains 17 points on the SmartRegs checklist. Installing $1 \mathrm{~kW}$ of $P V$ is awarded 44 points.

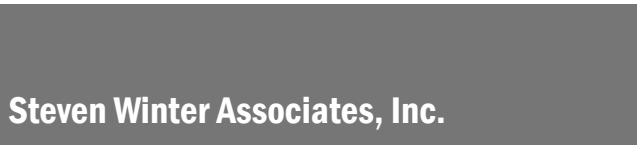

www.swinter.com

61 Washington St. Norwalk, CT 06854 307 7th Ave. Ste. 1701, New York, NY 10001 1112 16th St., NW Ste. 240, Washington, DC 20036 tel 203-857-0200 fax 203-852-0741 tel $212-564-5800$ fax 212-741-8673 tel 202-628-6100 fax 202-393-5043 


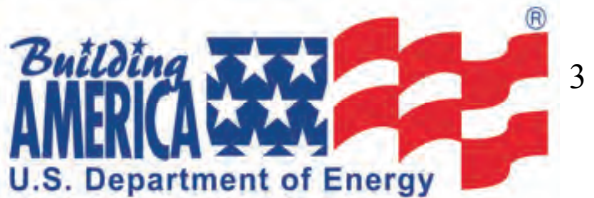

Boulder, CO

Predicted annual utility bills for the home As-Is (according to SWA's audit) and for each upgrade package outlined on the previous page are displayed in the graph to the right. For the As-ls case, REM/Rate predicts an annual utility bill of $\$ 1,250$ : the bulk of the bill, about $38 \%$, is attributed to heating.

Predicted utility bill savings for the first option package $-90 \%$ efficient boiler, 100\% CFL lighting and installing an Energy Star refrigerator (HERS index of $105)$ - average $\$ 231$ per year.

The second upgrade option-adding $1 \mathrm{~kW}$ of solargenerated power (HERS Index of 128) - results in predicted annual energy savings of $\$ 148$ per year.

Predicted emissions for each scenario are shown at right. It should be noted that even though the addition of $1 \mathrm{~kW}$ of $\mathrm{PV}$ results in only a $7 \%$ reduction in energy consumption at the site ${ }^{1}$ (as compared to a $23 \%$ reduction from package 1 ) it results in very similar reductions of emissions: $18 \%$ reduction in $\mathrm{CO}_{2}$ for PV vs. a 22\% reduction for package 1.

When production and transmission losses from the power plant (the source ${ }^{2}$ ) are factored in, emissions due to electricity generation increase by a factor of 3.33. Therefore, even though Package \#2 saves fewer MMBtu's at the site than Package \#1 (7\% reduction vs. $23 \%$ ), it results in a bigger reduction in greenhouse gases per MMBtu saved (table at right) when energy use at the source is considered.

This demonstrates the point from the previous page that reductions in electric use result in bigger emissions savings than those that reduce heating provided by natural gas. Therefore, improvements that reduce electric use are more heavily weighted than those that reduce gas use.
Figures \& Statistics

\section{Predicted Annual Utility Bills}

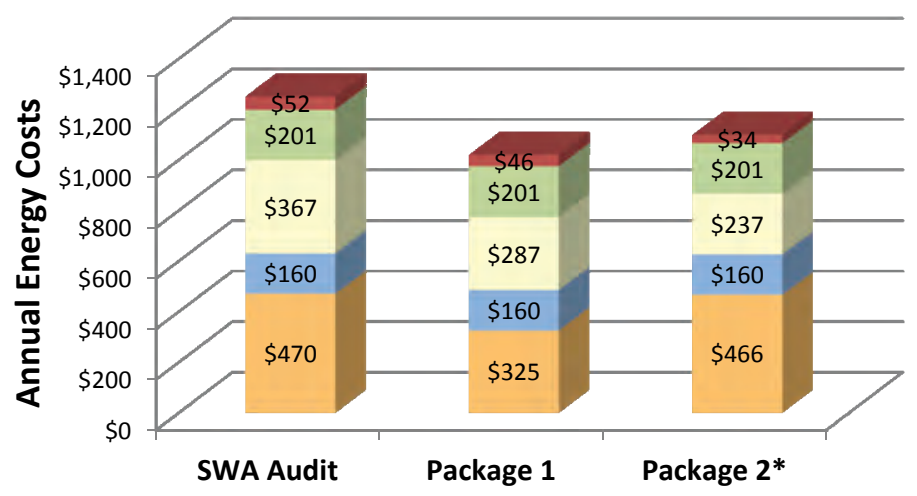

$\square$ Heating $\square$ Water Heating Lights \& Appliances $\square$ Other $\square$ Cooling

* Savings from Photovoltaics incorporated into Cooling and Lights \& Appliances categories

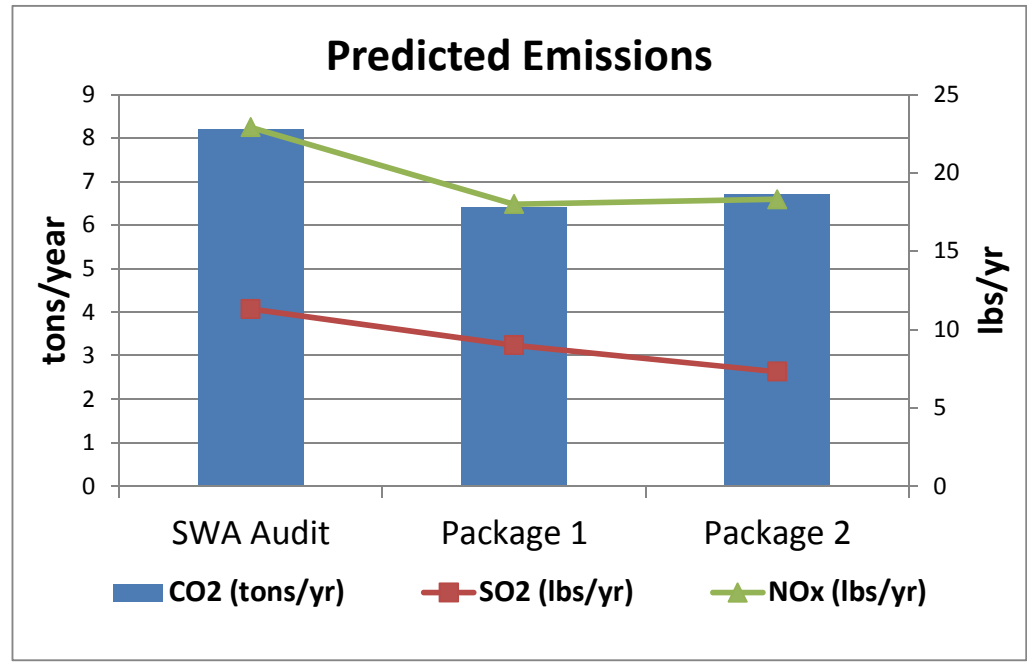

1 Site Energy Use: The energy directly consumed at a site (in this case the home) typically measured with utility meters.

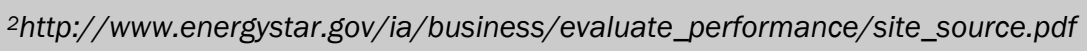

3Source Energy Use: The sum of the energy consumed at a site PLUS the energy required to extract, convert, and transmit that energy to the site.

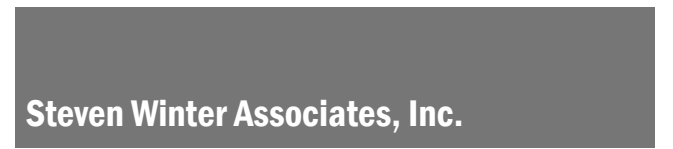

www.swinter.com

61 Washington St. Norwalk, CT 06854

307 7th Ave. Ste. 1701, New York, NY 10001

1112 16th St., NW Ste. 240, Washington, DC 20036 tel 203-857-0200 fax 203-852-0741 tel 212-564-5800 fax 212-741-8673 tel 202-628-6100 fax 202-393-5043 


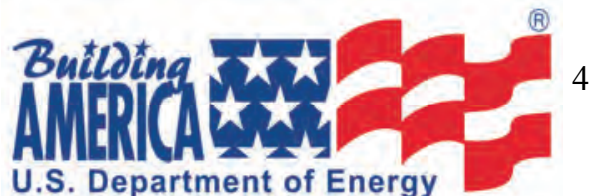

U.S. Department of Energy

\section{Cold Climate Region: Case Study \#7 Effects of Occupant Behavior

\section{Boulder, CO}

Up to this point, the discussion about improvements, utility bills and emissions has all been based on the results of the audit conducted by SWA in August of 2011. But, as noted in the introduction, this apartment had received a SmartRegs inspection prior to this audit. What was discovered was that, in the time between the two inspections, the occupant had made a couple of changes that negatively impacted the energy efficiency of that unit, and hence the SmartRegs score and HERS Index.

The two significant changes made include:

1. A window $\mathrm{A} / \mathrm{C}$ was installed. In addition to in creasing electric use, this change resulted in increased air leakage, because it was installed with a significant gap around the edges. If left in place during the winter, this will have a sig nificant impact on the energy used for heating.

2. Some of the CFL's were replaced with incandescent lights reducing the overall percent of CFL's from $100 \%$ to $38 \%$.

These changes result in a loss of 11 points on the SmartRegs checklist, taking the score from 85 down to 74. The HERS Index was likewise affected. That score changed from 130 to 147 (lower is better).

Overall, it is predicted that these occupant changes will increase the annual energy use by approximately $12 \%$, increase $\mathrm{CO}_{2}$ emissions by $16 \%$, and will result in a $\$ 152$ increase in annual utility bills. The affects of these changes are summarized in the graph and table to the right.

Of the nine case studies conducted to date, this was the first one where occupants had made a physical change that negatively altered the energy consumption and, hence, the SmartRegs score.

While it is anticipated that differences in occupant behavior (different thermostat set points, use of hot water, operation of windows during cold weather) will result in different energy use profiles for the same apartment, it is still unknown how big an affect the occupants will have on the City of Boulder's goals to reduce greenhouse gas emissions.

\section{Figures \& Statistics}

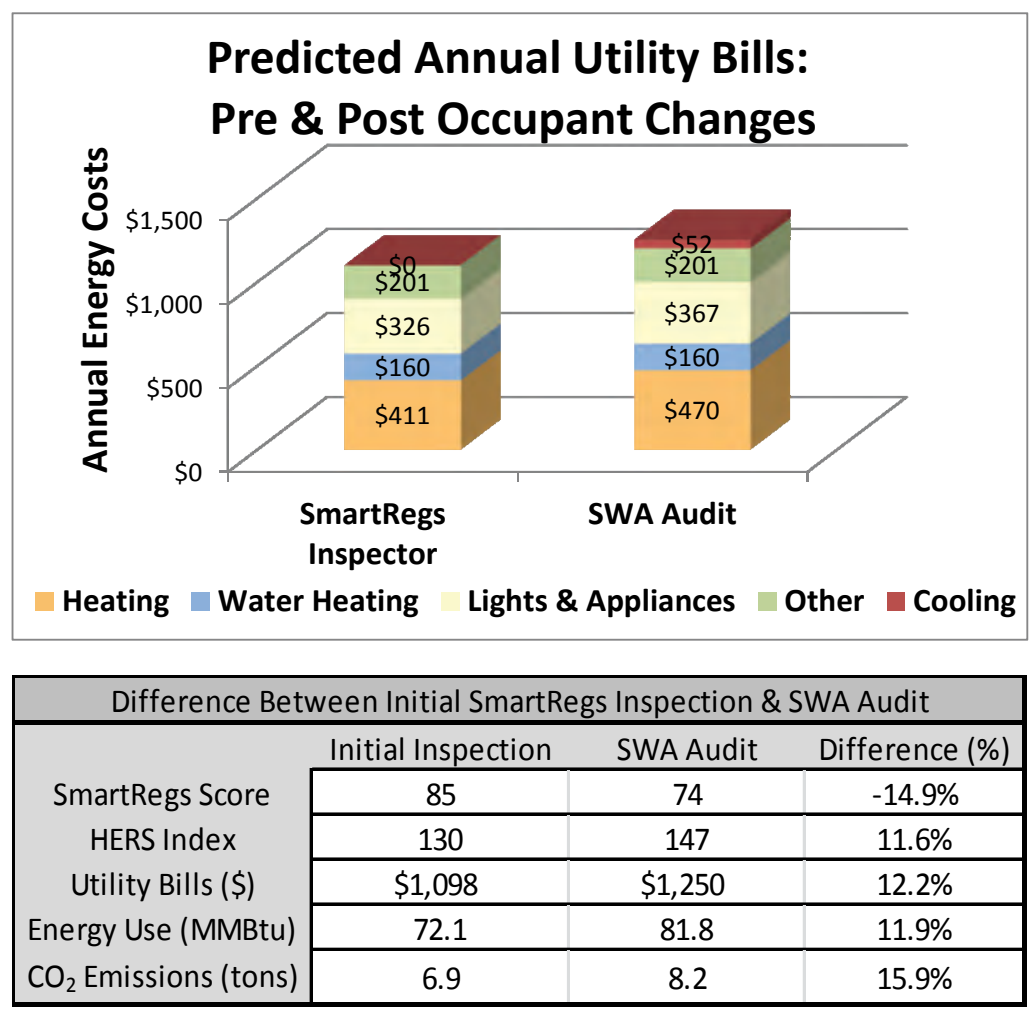

Will changes be made that permanently and negatively affect air leakage? Will insulation be moved or compressed? Will CFL's be replaced with incandescent bulbs as was done here? What is the likelihood that these types of alterations will occur?

It can easily be concluded that, in Colorado's climate, addition of window $\mathrm{A} / \mathrm{C}$ units is more likely to occur in poorly insulated homes and those with high solar gain during the summer. It also seems likely that occupants are more likely to change out CFL's from decorative fixtures without covers. Possible recommendations for changes to the program may include:

1. Unless a home has a minimum level of attic insulation and decent windows, points should not be awarded for the lack of a cooling system. Or, perhaps those points should not be awarded unless the home achieves a certain minimum score as is done with the points given for PV.

2. CFL's will not be given credit in decorative fixtures where the bulbs are entirely exposed, such as a chandelier.

Obviously, nine audits are not sufficient to make any definite conclusions. Follow up audits in the next couple of years may provide clearer answers to these types of questions. 


\section{Boulder, $\mathrm{CO}$}

The property manager was interviewed and asked to share her feelings and concerns about Boulder's new SmartRegs ordinance. A summary of her opinions and suggestions for improvements are below.

Q: Why did you decide to participate now and not wait till later in the process?

A: The owners wanted to get a baseline worst case scenario so they could plan on how to most costeffectively bring their properties into compliance.

\section{Q: How many rentals does the owner have in their} portfolio?

A: The owner has about 50 rental units in the city, the oldest of which was built in 1936.

Q: Are you educating the occupants about what and why renovations are taking place and how it will benefit them?

A: Yes. At first the property manager was informing occupants of what was happening in writing, but now she verbally informs. She takes a couple of minutes to explain what's happening and that it won't cost the tenants any money.
Q: What is your normal maintenance routine - ie., every few months, once a year, on occupant turn over?

A: Boiler maintenance is conducted every fall. All other improvements are conducted on an as-needed basis.

\section{Q: What has been the biggest challenge for you throughout this process?}

A: Getting the releases signed was the hardest part at first, so they incentivized them - $\$ 5$ gift card. After the first few, they have experienced no problems getting the releases. The biggest occupant complaints are about the low-flow showerheads.

Q: What would you like other property owners to know?

A: It's always better to have the information up front. Owners are not required to do anything right now. As many other managers/owners have noted in these interviews, this manager also stated that the energy advisor service has been very helpful to them.

Steven Winter Associates, Inc. is the lead for the Department of Energy's Building America team called the Consortium for Advanced Residential Buildings (CARB).

CARB would like to thank Populus, LLC , a sustainable design consulting firm and the program administrator for the City of Boulder's SmartRegs program, for their expertise, time and assistance in creating these case studies. 


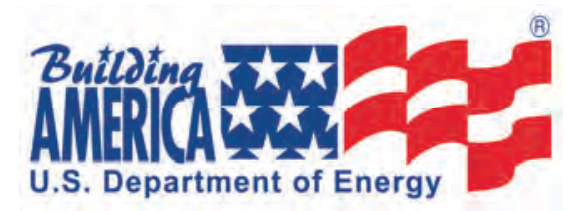

\section{E. College Ave Apartments: Case Study \#8 City of Boulder, SmartRegs Ordinance Low-Rise Multi-Family, 1950's Vintage}

\begin{tabular}{|ll}
\hline Boulder, CO & \\
\hline Program & SmartRegs Ordinance \\
Location: & Boulder, CO 80303 \\
Building Type: & Low-Rise Multi-Family \\
Building Size: & $17550+\mathrm{ft}^{2}$ living space \\
Foundation: & Slab-on-grade \\
HVAC/DHW: & In-unit gas heat, central HW \\
Configuration: & 2 Stories \\
Unit count: & 18 1-br, 18 2-br, 1 3-br \\
SWA Contact: & Lois Arena \\
& \\
\hline
\end{tabular}

SmartRegs requirements were adopted to meet the City of Boulder's sustainability objectives including environmental health, economic vitality and social equity. According to current statistics, rental properties comprise approximately 50 percent of Boulder's housing stock ${ }^{1}$. Therefore, by requiring property owners to upgrade rental properties, the SmartRegs program aids in advancing Boulder's community sustainability objectives, and will hopefully result in lower energy bills for tenants.

The program offers two compliance paths; one that uses a prescriptive checklist to rate energy efficiency, and one that uses an energy model. As will be demonstrated in this case study, energy models are not meant to be exact, but indicative, and are not meant to predict exact energy costs or energy cost savings. They are meant to be used as a tool to better understand the impact of energy efficient upgrades. If utility bills are available and performance testing conducted, the energy models can be calibrated to yield more accurate results.

In order to demonstrate compliance with SmartRegs, the property owner of these 37 rental units opted to use the Prescriptive Checklist. Prior to upgrades, these units were well below the 100 point threshold. The complex was constructed in the 1950's, with minimal attic insulation, no wall insulation, and single pane windows. Heating is provided by ductless in -unit natural gas heaters and hot water is provided by 6 centrally located gas storage water heaters. No cooling or mechanical ventilation is provided, although some tenants install window air conditioners on their own. Actual annual bills per unit range from $\$ 200-\$ 600$ for electricity and $\$ 250-\$ 550$ for natural gas, with almost $\$ 210$ in just monthly service charges.

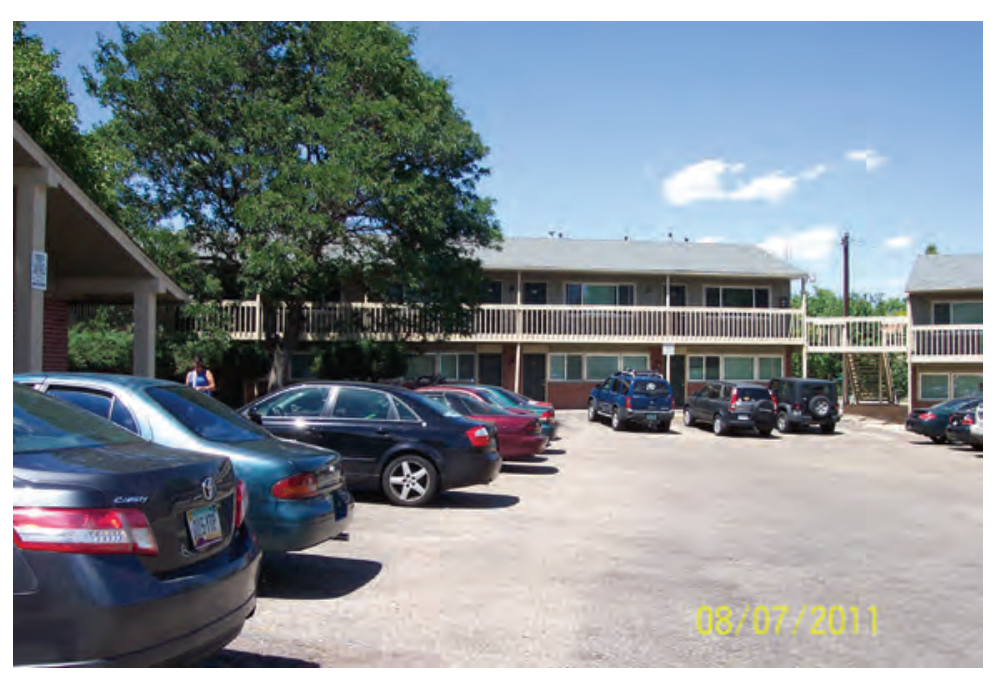

This 2-story, multi-family apartment building in Boulder, co underwent extensive retrofits to all its $\mathbf{3 7}$ units.

Energy Efficient Improvements
\begin{tabular}{llc} 
& Before & \multicolumn{1}{c}{ After } \\
Attic: & R-9 attic insulation & R-50 blown-in cellulose \\
Walls: & R-0 & R-13 blown-in cellulose \\
Windows: & Single, metal & Double, low-e, vinyl \\
Slab floor: & R-0 & same \\
Doors: & Metal doors & Foam-filled, fiberglass \\
Air Leakage: & 11.4 ACH50 & 8.7 ACH50 \\
Appliances: & $750 \mathrm{kWh} / \mathrm{yr}$ & 450 kWh/yr \\
Lighting: & Upgraded to 30-100\% compact fluorescents \\
Heating & $60 \mathrm{AFUE}$, natural gas & same
\end{tabular}

\section{Additional SmartRegs Features \\ None}

SmartRegs Checklist Score*: 106 to 117 points (Score must be $\geq 100$ points)

HERS Index: from 87 to 100

*100 points on the SmartRegs checklist should approximately equate to a HERS index of 120. 


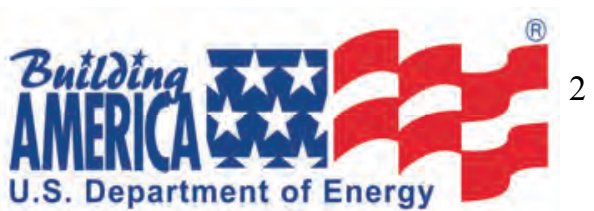

\section{Boulder, CO}

Each apartment is scored individually in the Smart -Regs program to account for floor plan configuration differences. Differences in layout and location can result in different exposed envelope areas, which in turn, can affect the SmartRegs score. For example, a corner unit on the 1st floor will generally have a lower SmartRegs score than an interior unit on the 1st floor, because that interior unit will have a greater percentage of shared walls (see Wall section of checklist below).

\begin{tabular}{|c|c|c|c|c|}
\hline WALLS & \multicolumn{2}{|c|}{ Base: } & \multicolumn{2}{|c|}{ Final: } \\
\hline R-VALUE & $25 \%$ & $50 \%$ & $75 \%$ & $100 \%$ \\
\hline No Insulation & 0 & 0 & 0 & 0 \\
\hline$\geq \mathrm{R}-3$ Continuous & 3 & 6 & 9 & 12 \\
\hline R-5 Continuous & 4 & (8) & (12) & 15 \\
\hline$R-13$ & 5 & 10 & 15 & 20 \\
\hline Uninsulated Basement Wall & 5 & 10 & 15 & 20 \\
\hline$\geq \mathrm{R}-19$ & 5 & 11 & 16 & 21 \\
\hline Insulated Basement Wall & 6 & 13 & 19 & 26 \\
\hline Shared Wall & (6) & (13) & 19 & 26 \\
\hline
\end{tabular}

Likewise, mid-level units with shared floors and ceilings will generally score higher than groundlevel or top-floor units.

The following table lists the SmartRegs scores for an interior 1 bedroom unit and an interior 2 bedroom unit, which represent 26 of the 37 units. A

\begin{tabular}{|l|c|c|c|}
\hline $\begin{array}{l}\text { Pre-Retrofit } \\
\text { SmartRegs }\end{array}$ & $\begin{array}{c}\text { Corner,1 BR } \\
\text { 1st floor }\end{array}$ & $\begin{array}{c}\text { Interior,2 BR } \\
\text { 1st floor }\end{array}$ & $\begin{array}{c}\text { Interior,1 BR } \\
\text { 2nd floor }\end{array}$ \\
\hline HERS & 157 & 79 & 58 \\
\hline
\end{tabular}

ground-level corner 1 bedroom unit with an attic above, is listed to demonstrate the worst case. The 1st floor interior unit scored more than the other units because a shared ceiling is worth 27 points and the existing attic insulation in the other two units did not earn any points in the checklist.

Because the minimum allowable SmartRegs score is 100 points, the property owner needed to improve the property by 2019 in order to maintain the rental permit required by the City of Boulder.

Using the worse case 1st floor corner unit as an example, at least 52 points were needed to meet the SmartRegs threshold.

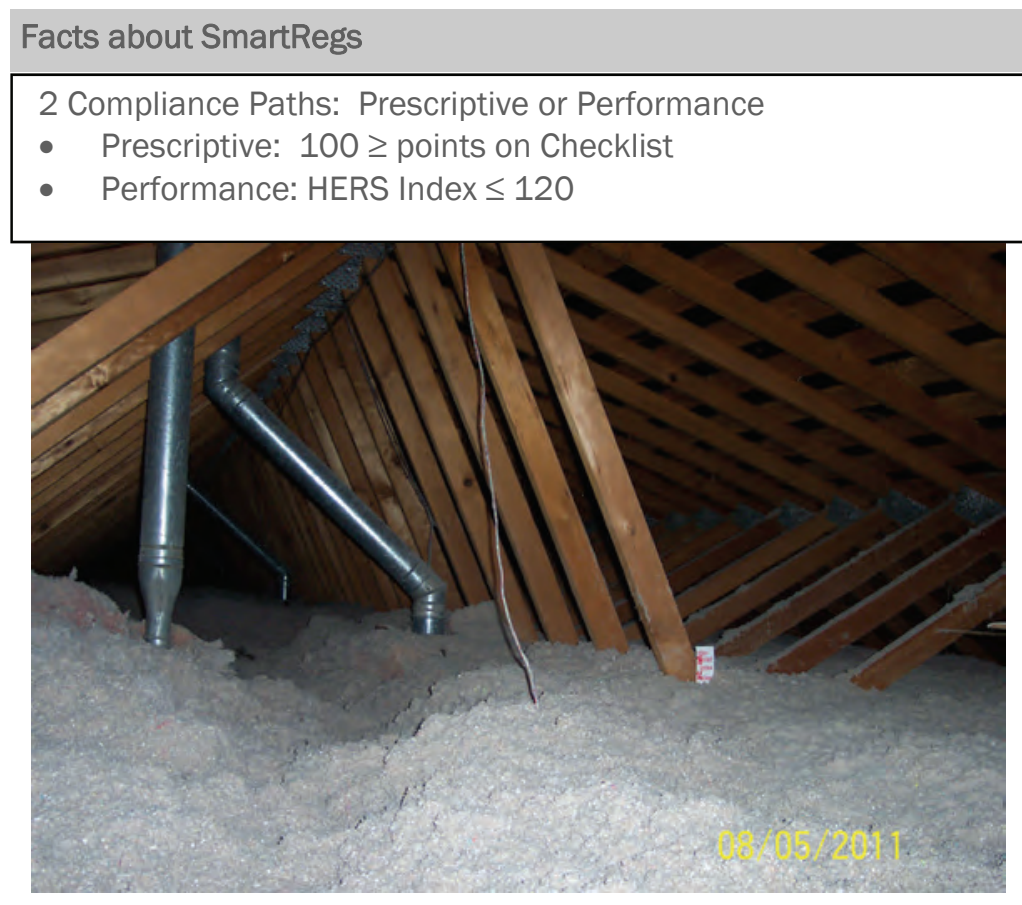

The attics are now insulated with approximately 13" of $R-50$ cellulose loose-fill insulation

These were achieved with a package of improvements that included:

- $\quad 13$ " of blown cellulose attic insulation (26 points)

- New double-pane, low-e windows with U-values of 0.3 (13 points)

- $\quad$ R-13 blown cellulose wall insulation (10 points)

- CFL replacement in $100 \%$ of lights (7 points)

- New ENERGY STAR qualified refrigerator (3 points)

- Reduced air leakage to <0.5 air changes/hour (2 points)

\begin{tabular}{|l|c|c|c|}
\hline Post-Retrofit & $\begin{array}{c}\text { Corner,1 BR } \\
\text { 1st floor }\end{array}$ & $\begin{array}{c}\text { Interior,2 BR } \\
\text { 1st floor }\end{array}$ & $\begin{array}{c}\text { Interior,1 BR } \\
\text { 2nd floor }\end{array}$ \\
SmartRegs & 109 & 106 & 117 \\
\hline HERS & 97 & 100 & 87 \\
\hline
\end{tabular}

Although the same package of improvements were implemented, the post-retrofit SmartRegs scores vary per unit, depending on the number of shared walls and ceilings.

The HERS Indices for these units post-retrofit were determined using energy models and ranged from 87 for the 2nd floor unit to 100 for the 1st floor unit. Although a HERS index is not required when using the Prescriptive checklist, it supports the claim that earning at least 100 points on the SmartRegs checklist should approximately equate to a HERS index of 120 points, which is the maximum HERS score allowed when using the Performance path for compliance.
Steven Winter Associates, Inc.
wWW.swinter.com

61 Washington St., Norwalk, CT 06854

307 7th Ave. Ste. 1701, New York, NY 10001

1112 16th St., NW Ste. 240, Washington, DC 20036 tel 203-857-0200 fax 203-852-0741 tel 212-564-5800 fax 212-741-8673 tel 202-628-6100 fax 202-393-5043 


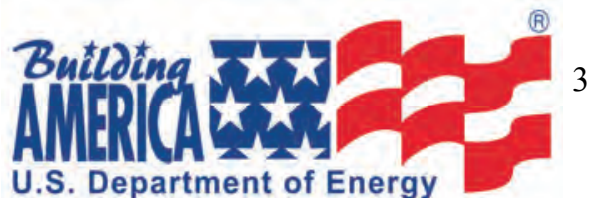

\section{Boulder, CO}

The energy model was not only used to calculate the HERS index, but to estimate the annual utility costs both pre- and post-retrofit for a sample of units.

For a second floor interior 1 bedroom unit, the combination of the upgrades accounts for a $40 \%$ savings between modeled pre and post-retrofit utility bills, for an estimated energy cost savings of about $\$ 450$ per year.

In the pre-retrofit case, REM/Rate predicts that heating comprised more than one third of the annual energy costs. This was reduced by $\$ 384$ through the wall and attic insulation, window and door upgrades, and reduced air leakage.

Lights and appliances are the next largest end-use, and \$66 in annual savings are predicted by lowering electricity consumption through energy-efficient lighting and a new refrigerator. The "Other" category includes monthly service charges that are unfortunately unaffected by energy efficient improvements and comprise almost $20 \%$ of the bill.

Pre-retrofit utility bills (shown in the lower two graphs at right) were available for a handful of 1 bedroom units which show spikes in electricity usage in both winter and summer. Although it is suspected that some units may have supplemented gas heating with electric resistance heating in the winter and may have installed window airconditioning units in the summer, these were not accounted for in the energy model, as no confirmation of this was provided by property managers. Some pre-retrofit bills, therefore, show that the annual electricity consumption is higher than predicted from the energy model.

Beyond what was described above, the model makes assumptions on things like weather, thermostat settings, and how long lights are left on. This can also lead to a discrepancy between actual bills and savings estimated by the model. If actual pre-retrofit energy usage is greater than modeled, actual savings may be higher than predicted. But in this case, the models predicted higher gas usage than shown in the actual bills, therefore, actual gas savings will likely be less than predicted.

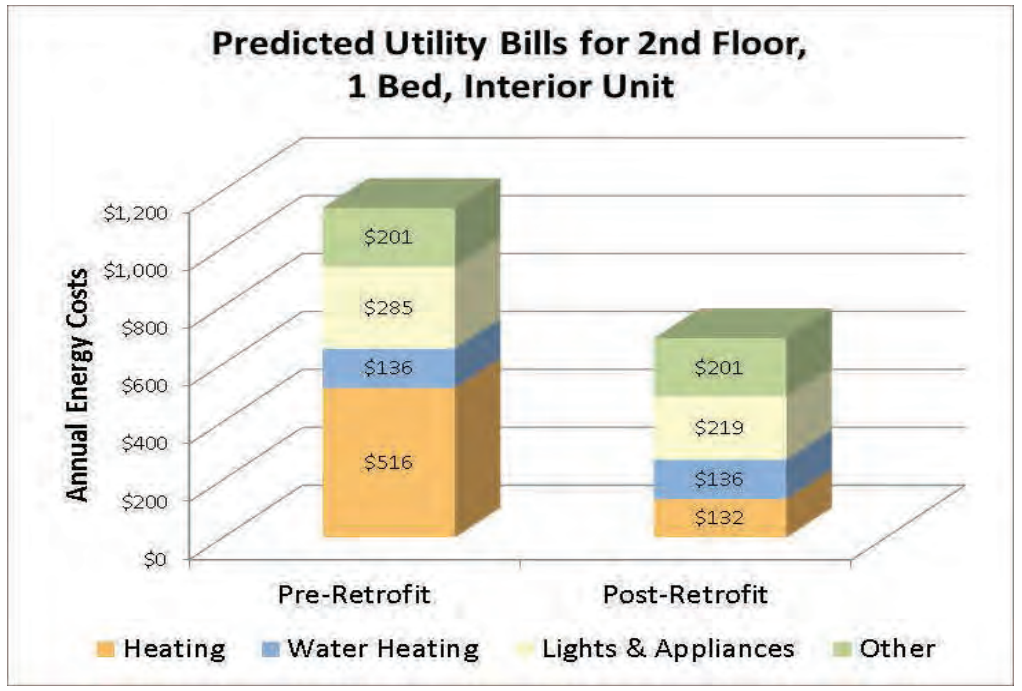

$40 \%$ reduction in utility bills expected post-retrofit

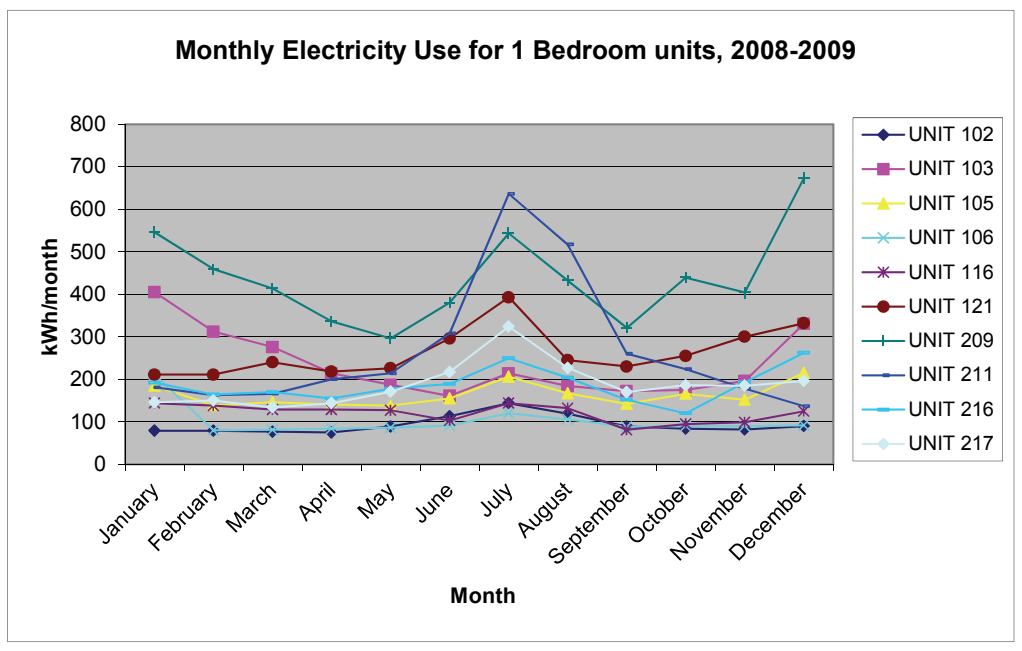

Monthly Gas Use for 1 Bedroom units, 2008-2009

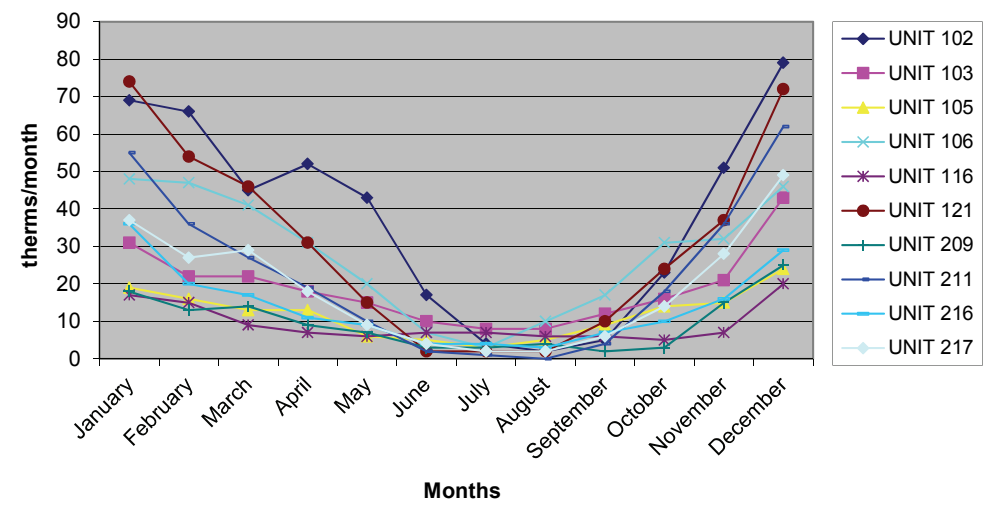




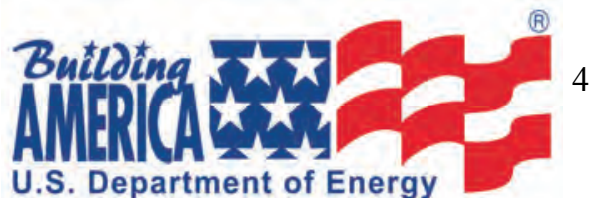

\section{Boulder, CO}

The same analysis was conducted for a first floor interior 2 bedroom unit and the combination of the upgrades account for a $23 \%$ savings between modeled pre and post-retrofit utility bills, for estimated energy cost savings of about \$231 per year. Although a slightly larger unit than the previous analysis, the overall energy use is less than the second floor unit due to the shared ceiling and, therefore, the associated savings are also less.

For these units, heating still comprises about one third of the annual energy costs. This was reduced by $\$ 194$ through the wall insulation, window and door upgrades, and reduced air leakage. Lights and appliances are again the next largest end-use, and \$37 in savings were achieved with compact fluorescent lighting and a new refrigerator.

As shown in the graphs to the right, the model sometimes under predicted and sometimes over predicted electricity consumption. Under predictions were mostly related to units with surges in electricity usage in the summer most likely from using window air conditioners (usually units on the 2nd floor); over predictions could result from reductions in occupancy as is typical of student housing. Based on the actual bills, $\$ 40-\$ 120$ per year is expected in electricity savings per unit.

Unlike the predictions for electricity consumption, the models consistently and significantly over predicted gas consumption (see graph bottom right). It is suspected that the units are not being directly billed for the natural gas for the central water heaters ( 150 therms per unit per year), but this does not explain the entire discrepancy. Multiple studies have shown that modeling software tends to over predict heating energy use in older, inefficient homes. This study definitely supports those observations.

With this in mind, it is expected that heating costs will still be reduced significantly due to the upgrades, but more along the lines of $\$ 40-150$ per year, depending on location and size of the unit. This estimate is based on the actual pre-retrofit bills and the percent reduction in heating energy use that can be expected from the upgrades performed.

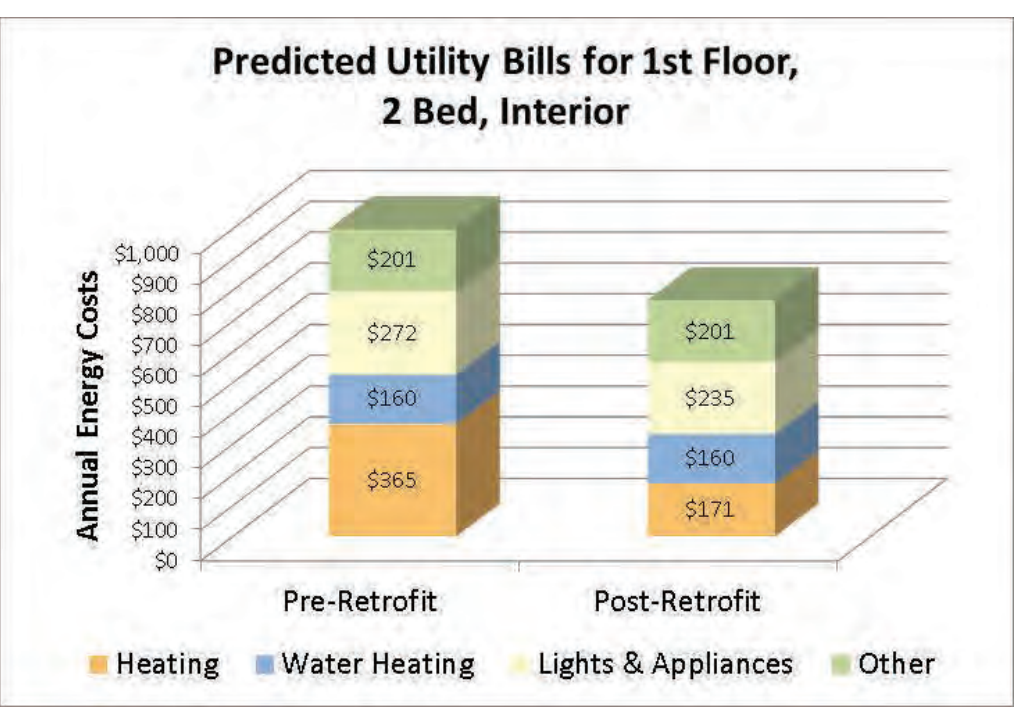

$23 \%$ reduction in utility bills expected post-retrofit
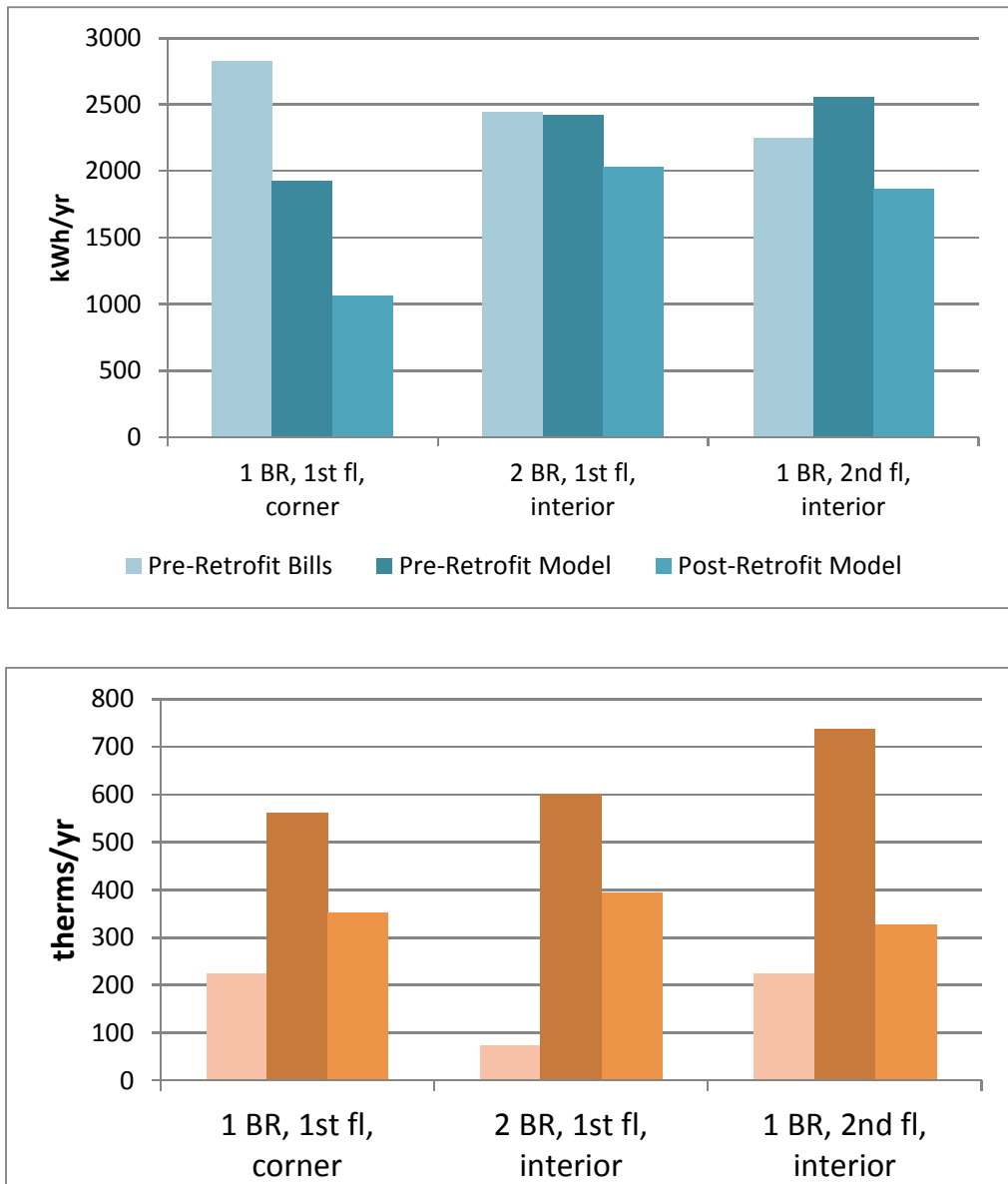

Pre-Retrofit Bills Pre-Retrofit Model $\square$ Post-Retrofit Model

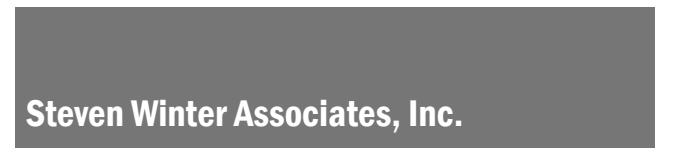

www.swinter.com

61 Washington St., Norwalk, CT 06854

307 7th Ave. Ste. 1701, New York, NY 10001

1112 16th St., NW Ste. 240, Washington, DC 20036 tel 203-857-0200 fax 203-852-0741 tel 212-564-5800 fax 212-741-8673 tel 202-628-6100 fax 202-393-5043 


\section{Boulder, $\mathrm{CO}$}

The property managers were interviewed and asked to share their feelings and concerns about Boulder's new SmartRegs ordinance. A summary of their opinions and suggestions for improvements are below.

Q: Why did you decide to participate now and not wait till later in the process?

A: A few years ago, one of the tenants wrote a letter to the owner explaining how inefficient the units were. This inspired the owner to do an extensive green retrofit to this property. He knew that the SmartRegs program was being developed, and since all the units needed to be remodeled, thought this was a good opportunity to make it a green remodel.

Each unit went up in price by about 25 - 30\% after the remodel was completed, but managers have had no problem renting them.

\section{Q: Are you educating the occupants about what and why renovations are taking place and how it will bene- fit them?}

A: Yes, agents promote the green items, low utility bills and new windows. Students are really interested in this.

Q: What is your normal maintenance routine - i.e., every few months, once a year, on occupant turn over?

\section{Q: What has been the biggest challenge for you throughout this process?}

A: The managers were skeptical at first, but the requirements turned out to be not as bad as anticipated. One of the challenges noted was that the rebates from Xcel were not always available.

\section{Q: What would you like other property owners to know?}

A: The managers and the owner repeatedly mentioned that Populus has been a great liaison and that the advisors service has been invaluable. They also noted that they use the SmartRegs checklist used as a guide for planning their improvements.

Q: Do you feel that the occupants could have a negative effect on the retrofits.

A: This management company feels that the upgrades are durable. To date, no changes have been made to the work performed.

SWA did find compressed insulation and missing insulation on the hatch of one attic access areas, but it is suspected that this was caused by a contractor and not the occupants.

A: Heat techs check the heating system in each unit annually.

Steven Winter Associates, Inc. is the lead for the Department of Energy's Building America team called the Consortium for Advanced Residential Buildings (CARB).

CARB would like to thank Populus, LLC , a sustainable design consulting firm and the program administrator for the City of Boulder's SmartRegs program, for their expertise, time and assistance in creating these case studies. 

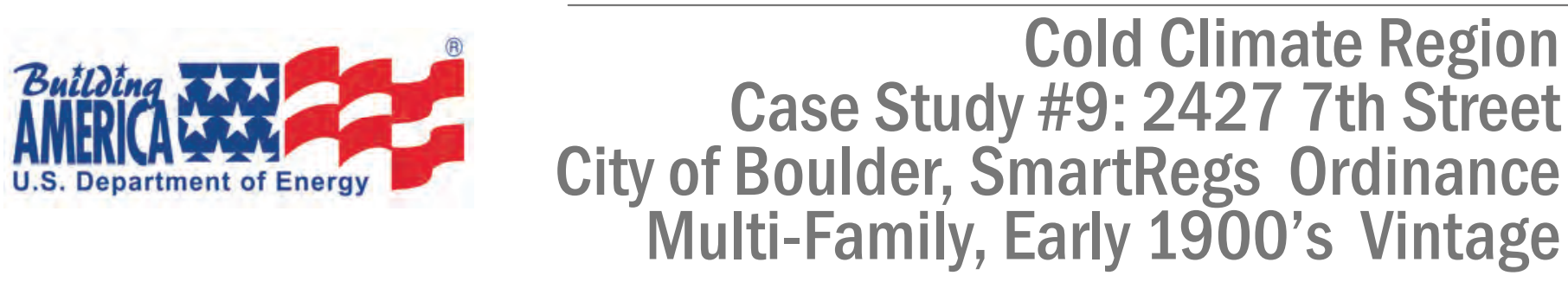

\begin{tabular}{|ll|}
\hline Boulder, CO & \\
\hline Program: & SmartRegs Ordinance \\
Location: & Boulder, Colorado \\
Building Type: & Multi-Family \\
Number of units: & 2 \\
Building Size: & $493 \mathrm{ft}^{2} 2^{\text {nd }}$ Floor $/ 611 \mathrm{ft}^{2} 11^{\text {st }}$ Floor \\
Foundation: & Basement/Crawlspace: Unconditioned \\
Configuration: & 2 bedrooms, 2 baths \\
SWA Contact: & Lois Arena \\
\hline
\end{tabular}

Due to their proximity to the University of Colorado, there are several older neighborhoods in Boulder that are dominated by rental properties. Many of these old, single family homes, such as this bungalow built in 1900, have been divided into more than one unit. Each floor of this two story home has been converted into an individual apartment.

According to Boulder's SmartRegs requirements, each rental unit in a building must be tested and scored separately. Unusual layouts, common walls and floors, shared equipment, and occupant use of the space can make this quite challenging. Efficiency levels and testing results for each unit in this home are shown in the table at right.

It is common when rating a multi-family building that some units will score better than others. Contributing factors include whether the unit is on the bottom, middle or top floor of the building, the amount of exposed surface to outside, and differences in lighting and appliances in each space. Differences in the HERS Index can also be the result of the affects of solar exposure and the amount of window area. In the case of this home, where percentage of above grade walls and efficiency levels are fairly similar between the two apartments, the resulting SmartRegs scores and HERS Indices are also fairly similar.

The $1^{\text {st }}$ floor unit in this building only scores 3 points lower on the SmartRegs checklist than the $2^{\text {nd }}$ floor unit. While the $1^{\text {st }}$ floor gained several more points for lights and appliances than the $2^{\text {nd }}$, it scored significantly worse in the foundation insulation category. The $2^{\text {nd }}$ floor gained 15 points for being located over conditioned space, but the $1^{\text {st }}$ gets zero for being over an uninsulated basement/crawlspace.

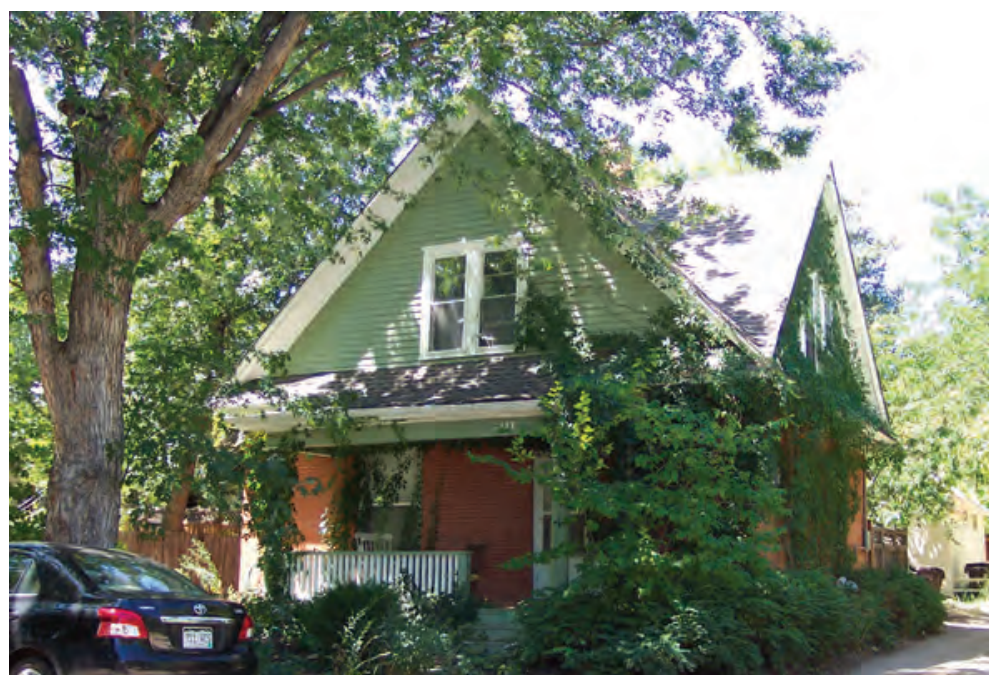

This home has been divided into two rental units. At this time, neither unit achieves 100 points on the SmartRegs checklist, therefore, efficiency improvements must be made.

\begin{tabular}{|c|c|}
\hline \multicolumn{2}{|c|}{ Energy Efficient Features } \\
\hline Attic: & R-19 blown cellulose \\
\hline Walls: & Uninsulated brick \\
\hline Windows: & Predominantly single pane wood + storms \\
\hline Foundation: & $\begin{array}{l}\text { Crawlspace R-0, } \\
\text { Basement R-0 }\end{array}$ \\
\hline Heating: & $\begin{array}{l}\text { Central system - forced air, natural gas, } 90 \\
\text { AFUE, in unconditioned basement }\end{array}$ \\
\hline Cooling: & None \\
\hline Ductwork: & Uninsulated \& in unconditioned space \\
\hline Hot Water: & $\begin{array}{l}\text { Atmospheric, natural gas, unconditioned } \\
\text { space, } 0.59 \mathrm{EF}\end{array}$ \\
\hline Air Leakage: & $\begin{array}{l}2^{\text {nd }} \mathrm{FI}: 25.23 \mathrm{ACH} @ 50 \text { pascals, } 1.14 \mathrm{ACHn} \\
1^{\text {st }} \mathrm{FI}: 32.29 \mathrm{ACH} @ 50 \text { pascals, } 1.45 \mathrm{ACHn}\end{array}$ \\
\hline
\end{tabular}

\section{Additional SmartRegs Features}

Low-flow faucets and showerheads, programmable thermostat

\section{SmartRegs Checklist Score*: 88 points $2^{\text {nd }}$ FI 85 points $1^{\text {st }} \mathrm{FI}$}

(The final score must be $\geq 100$ )

\section{HERS Index: $1392^{\text {nd }} F I / 1501^{\text {st }} F$ I}

*100 points on the SmartRegs checklist should approximately equate to a HERS index of 120 . 


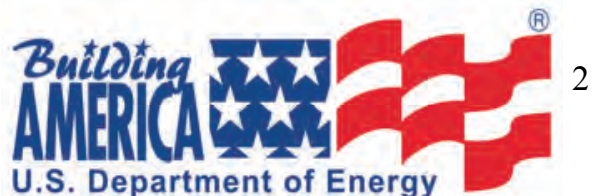

\section{Boulder, CO}

The minimum allowable score when using the prescriptive method for compliance with Boulder's SmartRegs ordinance is 100 points. The lower unit of this property scored 85 points and the upper 88 , therefore, the owner will have to improve both by 2019 in order to maintain their rental license.

When developing the SmartRegs checklist, program creators intended that 100 points should approximately equate to a HERS Index of 120 . Given this assumption, both apartments should have a HERS Index above 120 (the higher the HERS index the less efficient the home).

To validate this assumption, SWA modeled both units in this home using REM/Rate, a simulation program used to analyze the energy use of residential buildings. As anticipated, both units scored above 120: the upper unit received a HERS Index of 139, and the lower an index of 150.

Upon initial review of the audit results, it would appear that the owner has several options for improving the efficiency of this home. But, as is often the case when retrofitting an existing home, before energy improvements can be made other upgrades must be implemented for health or safety reasons. Since this extra work does not contribute to energy savings, the overall costeffectiveness of the improvement can be significantly reduced.

For example, adding insulation to this attic would generally be a cost-effective upgrade. But, given the age of this home, it could very well have knob and tube wiring. If it does, the wiring would have to be upgraded before any additional insulation could be added.

Likewise, insulating the foundation would be problematic. This space is currently being used for storage and is quite packed with belongings. A good majority of these items would have to be taken out to properly insulate the walls and install a vapor barrier over the exposed dirt of the crawlspace area. On top of this, the crawl space is under 2' tall toward the front of the home making improvements to that area very difficult.

\section{Facts about SmartRegs}

2 Compliance Paths: Prescriptive or Performance

- Prescriptive: $\geq 100$ points on Checklist

- Performance: HERS Index $<=120$

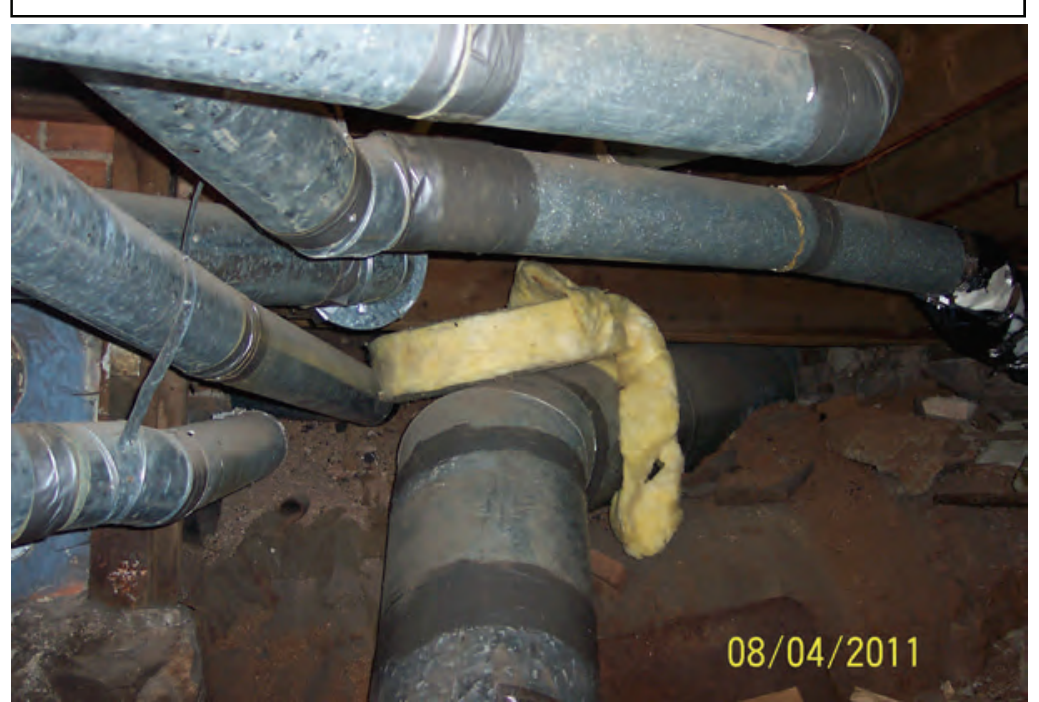

Uninsulated, partially sealed ductwork in the uninsulated basement/crawlspace

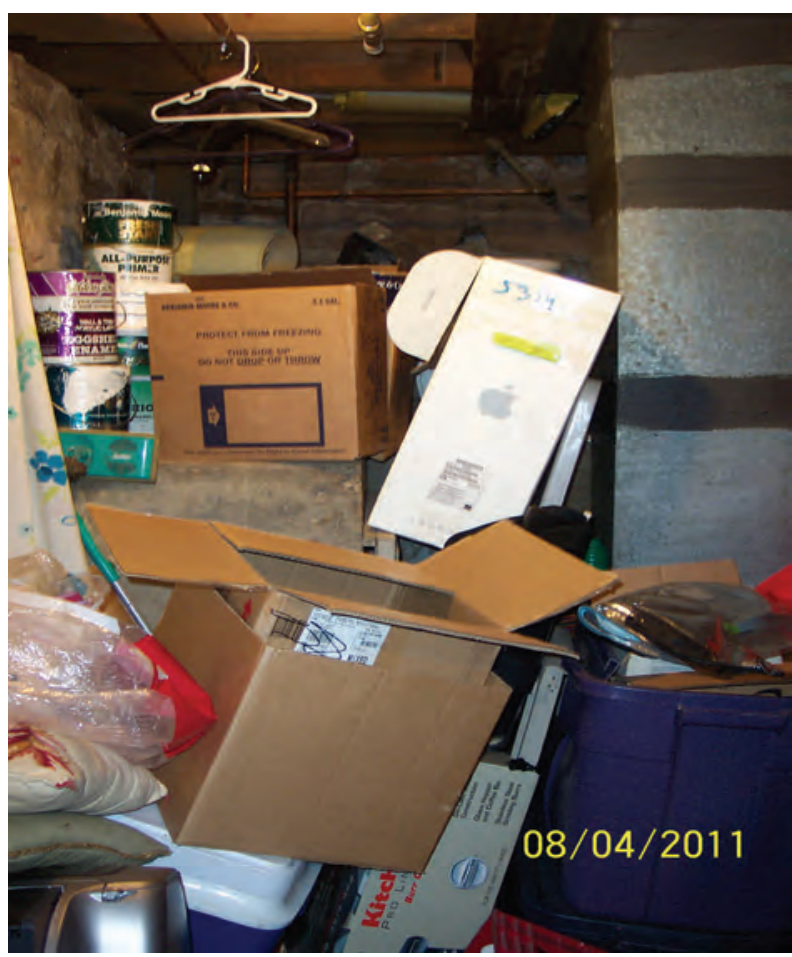

Basement and crawlspace are being used as storage making any retrofits in this area difficult and more costly.
Steven Winter Associates, Inc.
wWW.swinter.com

61 Washington St. 6th FI, Norwalk, CT 06854 307 7th Ave. Ste. 1701, New York, NY 10001

1112 16th St., NW Ste. 240, Washington, DC 20036 tel 203-857-0200 fax 203-852-0741 tel 212-564-5800 fax 212-741-8673 tel 202-628-6100 fax 202-393-5043 


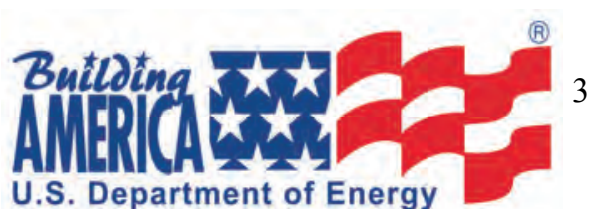

\section{Boulder, CO}

One option for owners of these hard to improve older buildings is installing a minimum of $1 \mathrm{~kW}$ of PV (photovoltaics) on the roof. Because this upgrade gains 44 points on the SmartRegs checklist, no other improvements would have to be made to this home. The only stipulation is that the home score at least 70 points on the checklist before this option can be used. Both of these units pass that criteria.

But again, house configuration and existing circumstances make installing PV on this house challenging. The image at the right shows this home's complicated roof configuration; hardly ideal for a PV installation. Also, large trees to the east, south and west will shade a good portion of this roof for much of the year. Both of these issues make installing an efficient PV system difficult at best.

With the above considerations in mind, the following improvement options for this property were analyzed:

- Replace the water heater with an instantaneous, 0.82 EF model (5 points);

- $\quad$ Reduce the air leakage in both apartments to 0.75 ACHn (4 points);

- $\quad$ Reduce the duct leakage by 50\% (9 points).

While some extra cost will be incurred to perform these improvements in this home as compared to a new or newer home, they should be more cost-effective than some of the other options discussed. The effects of these upgrades on the SmartRegs and HERS Indices for both apartments are shown in the following table.

\begin{tabular}{|r|c|c|}
\hline \multicolumn{3}{|c|}{ As-Is vs. Upgraded Scores } \\
\hline \multicolumn{2}{|c|}{ SmartRegs } & Hers Index \\
\hline 1st Floor & & 150 \\
Upgraded & 103 & 116 \\
\hline 2nd Floor & & 139 \\
As-Is & 88 & 109 \\
\hline
\end{tabular}

The analysis on both of these units shows good agreement with the goal of SmartRegs developers that 100 points should approximately equate to a HERS Index of 120. The scores both behaved in a consistent manner as well: when the SmartRegs score was below 100, the HERS Index was above 120, and vice versa.
Improvement Analysis

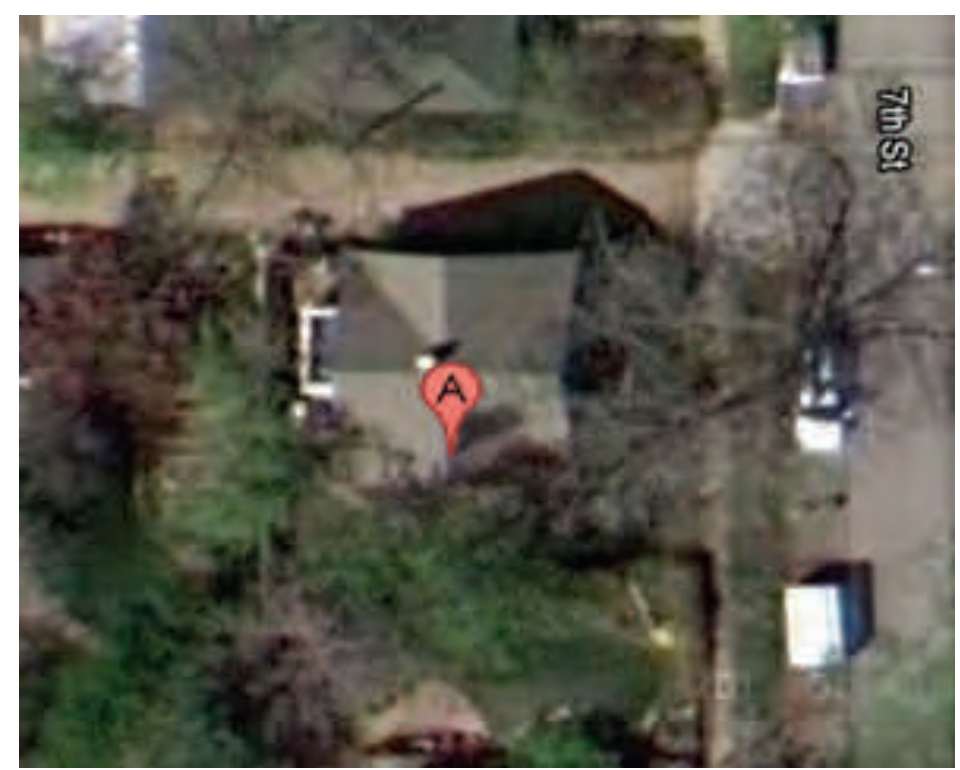

Satellite image showing complicated roof configuration and large trees to the east, south and west blocking solar exposure.

Predicted monthly utility bills for the first floor apartment are displayed in the graph below. REM/Rate predicts an annual utility bill of approximately $\$ 1000$ for the units As-ls (slightly more for the $1^{\text {st }}$ floor, and slightly less for the $2^{\text {nd }}$ ). For each apartment, the upgrades result in predicted utility bill savings of about 16\% (approximately $\$ 160 / \mathrm{yr}$ ) and reductions in emissions of about $15 \%$.

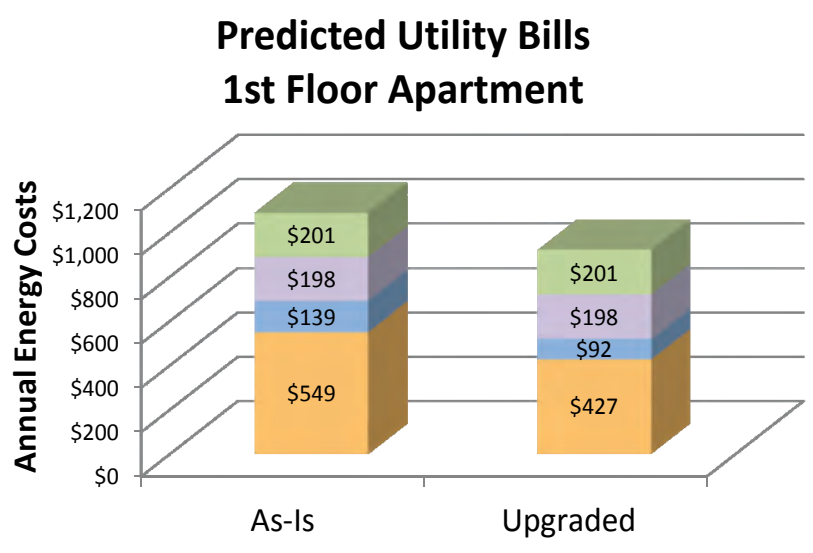

$\square$ Heating $\square$ Water Heating $\square$ Lights \& Appliances $\square$ Other
Steven Winter Associates, Inc.
wWw.swinter.com

61 Washington St. 6th FI, Norwalk, CT 06854 307 7th Ave. Ste. 1701, New York, NY 10001

1112 16th St., NW Ste. 240, Washington, DC 20036 tel 203-857-0200 fax 203-852-0741 tel $212-564-5800$ fax 212-741-8673 tel 202-628-6100 fax 202-393-5043 


\section{Boulder, $\mathrm{CO}$}

This property owner was interviewed to determine her feelings and concerns about Boulder's new SmartRegs ordinance. A summary of her opinions and suggestions for improvements are below.

Q. Why did you decide to participate now and not wait till later in the process?

A: The owner of this property chose to participate now to take advantage of free inspections and to start the planning process in the case that improvements would need to be made. This owner is very concerned with energy efficiency in general and had performed many enhancements before SmartRegs was passed.

\section{Q. How long has the owner owned this property?}

A: This property has been owned for approximately 25 years. She owns 2 properties with a total of 7 units.

Q. Are you educating the occupants about what and why renovations are taking place and how it will benefit them?

A: This owner actively educates students on environmental issues and energy efficiency. She recommended that the city create a "Tips for Tenants" worksheet to aid in the education process.
Q. What is your normal maintenance routine - i.e., every few months, once a year, on occupant turn over?

A: She provides enough furnace filters to her tenants every year for a monthly replacement. When there are no other expenses that year, the owner uses that opportunity to upgrade something. There have been no comfort complaints from her tenants.

Q: What has been the biggest challenge for you throughout this process?

A: The biggest challenge for this landlord has been improving such an old property. Often there are not cost-effective upgrade opportunities - brick walls, knob and tube wiring, plaster interiors, etc.

\section{Q: What would you like other property owners to know?}

A: As with most rental property owners interviewed during this process, this owner expressed that the process wasn't as difficult, and reaching compliance wasn't as hard as originally anticipated. She also felt that the EnergySmart advisors were very helpful.

\section{Q: Concerns?}

A: The owners biggest concern with the SmartRegs ordinance was having the local government make decisions over what she feels is her personal business.

Steven Winter Associates, Inc. is the lead for the Department of Energy's Building America team called the Consortium for Advanced Residential Buildings (CARB).

CARB would like to thank Populus, LLC , a sustainable design consulting firm and the program administrator for the City of Boulder's SmartRegs program, for their expertise, time and assistance in creating these case studies. 


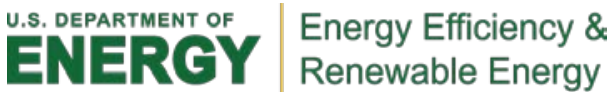

Appendix C Auditor Training 


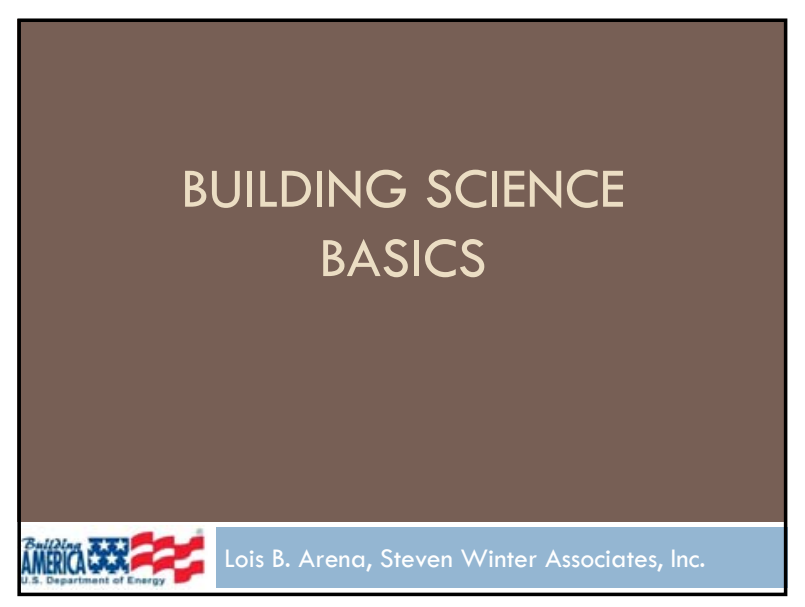

\section{Energy Definitions}

Energy Consumption:

$\square$ The amount of energy that is used over a period of time.

Energy Load:

$\square$ The amount of energy needed to meet a specific goal.

Houses consume energy to meet the loads needed to maintain comfort conditions.

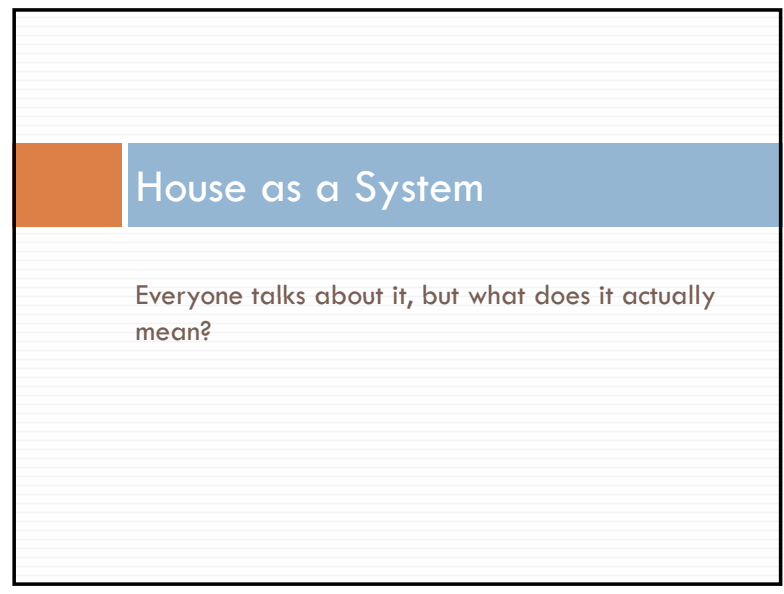

\section{Overview}

House as a System

$\checkmark$ Heat Transfer

$\square$ Moisture Transfer

$\checkmark$ Airflow

$\checkmark$ Thermal \& Pressure Boundaries

$\checkmark$ Identification of Components

$\neg$ Diagnostic Testing

$\square$ Ventilation Requirements \& Solutions

\section{How We Measure Energy}

\section{$\square$ British Thermal Unit (Błu)}

$\square$ The amount of energy it takes to change the temperature of 1 pound of water by 1 degree Fahrenheit

Or, about the same as the energy generated when burning a match from end to end...

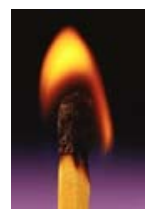

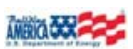

\section{House as a System Concept}

\section{System Interaction Examples}

- Adding insulation to an attic without air sealing could cause the roof to rot out.

- Installing a high efficiency furnace could cause the water heater to back draft.

- Air sealing the building could cause condensation on windows. 


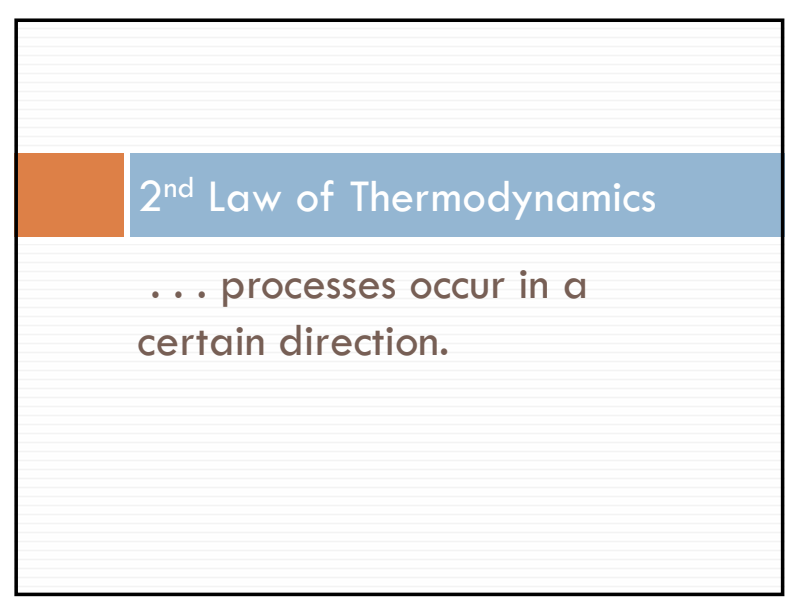

What you need to know most about the $2^{\text {nd }}$ Law...

$\square$ Heat moves to cold

$\square$ Air moves from high pressure to low pressure

$\square$ Moisture moves from higher concentrations to lower concentrations

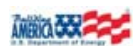

\section{Heat Transfer}

$\square$ Heat is a form of energy

$\square$ When heat moves from place to place, it is referred to as "Heat Transfer"

$\square$ Heat Transfer occurs in three ways:

$\square$ Conduction

$\square$ Convection

$\square$ Radiation
Why do we care about the $2^{\text {nd }}$ Law?

It applies to:
$\square$ How air moves
$\square$ How heat is transferred
$\square$ How moisture migrates
$\square$ How heating and cooling create comfort
......convinced yet?

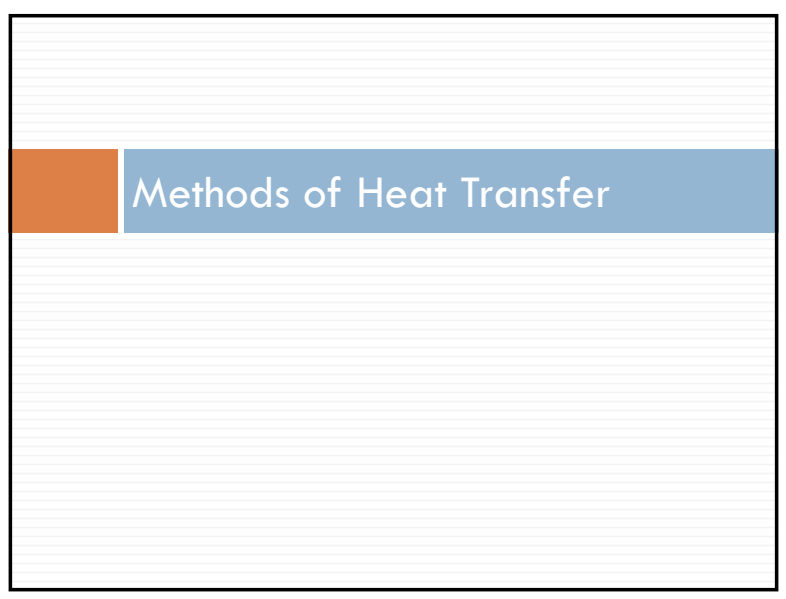

\section{Heat Transfer}

\section{$\square$ Conduction}

$\square$ Occurs when heat energy moves through a solid or fluid material

$\square$ Energy is transferred from one molecule to the next

$\square$ What are some examples of conduction?

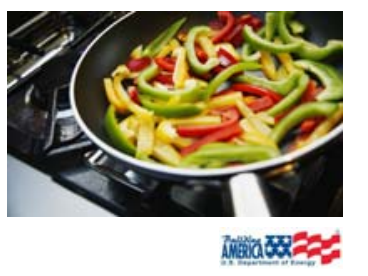




\section{Heat Transfer}

$\square$ Convection
$\square$ Convection occurs when heat is carried from one place
to another
$\square$ Convection requires a
"fluid medium"
(i.e. a gas or liquid)

\section{Convective Loops}

$\square$ When convection occurs in an enclosed space, the air (or fluid) will circulate around the space as it is heated and cooled, this is referred to as a convective loop

$\square$ What are some examples of places where convective loops could be found?

\section{Example: Convection}

$\square$ Convection in homes usually occurs when air in the house moves around due to temperature gradients

$\square$ Warm air is lighter (i.e. less dense) than cold air

$\square$ Cold air falls, warm air rises

\section{Heat Transfer}

\section{Radiation}

口 Heat that passes spontaneously from a warm body to a cold body

$\square$ The bodies must be in sight of each other but not in contact

$\square$ Radiation does not require a "medium" to carry the heat

$\square$ Give some examples

of radiant heat transfer

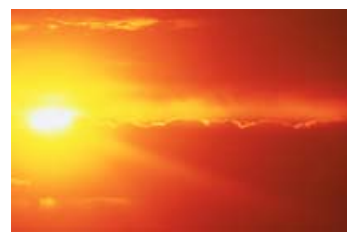

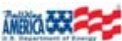

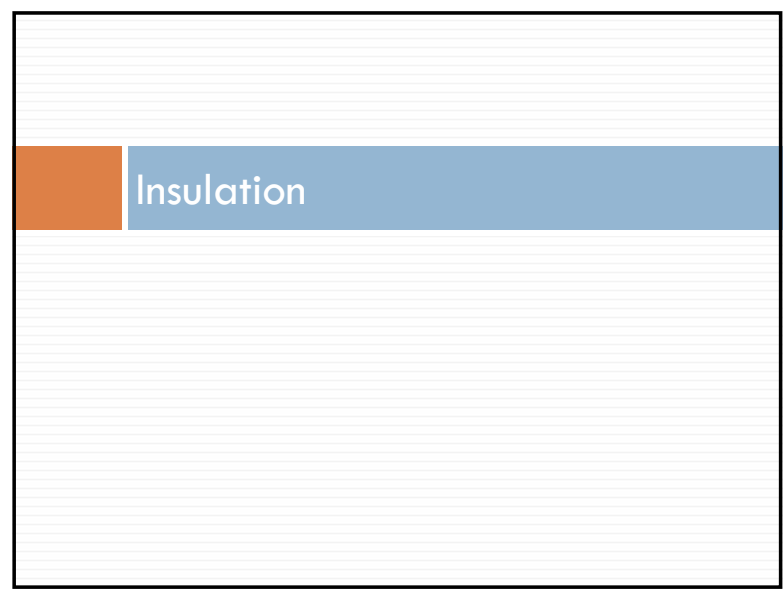

$R$-value $\left(h \cdot \mathrm{ft}^{2} \cdot{ }^{\circ} \mathrm{F} / \mathrm{Btu}\right)$

R-value is a measurement of a material's resistance to conductive heat transfer

$\square$ The higher the Rvalue, the better the insulator

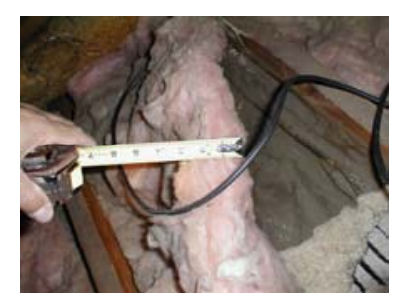




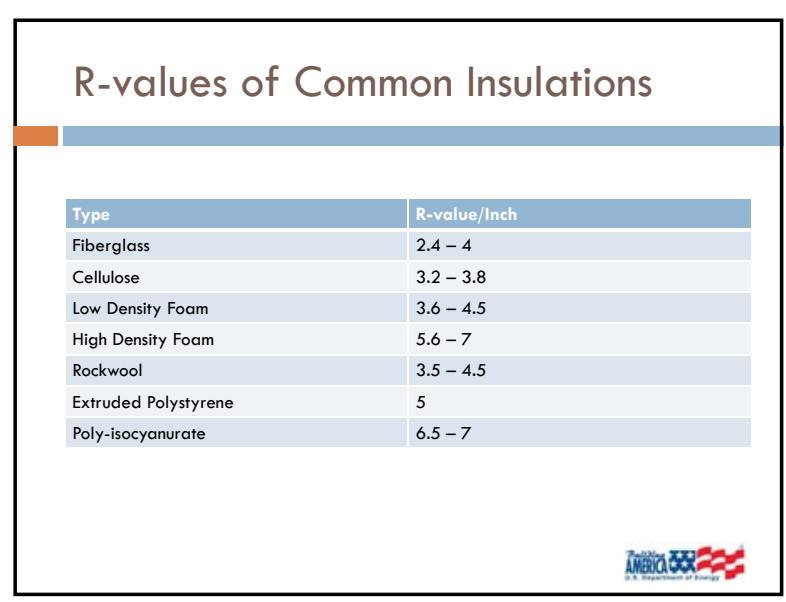

What Air Movement Does to Insulation...

$\square$ When air moves through insulation, there are no more still air pockets

$\square$ As a result, the effective $R$-value is reduced

$\square$ Remember:

$\square R$ per inch of wood $\approx 1.2$

$\square R$ per pane of glass $<1.0$

\section{Insulation}

Why is insulation light and fluffy?

$\square$ Small pockets in insulation trap still air

$\square$ The air is the insulator!
Other Factors Affecting Insulation Performance

$\square$ Compression (refer to manufacturer's compression charts)

$\square$ "Fluffing", especially blown fiberglass

$\square$ Voids and gaps, inconsistent coverage

$\square$ Moisture

$\square$ Not in contact with the surface it is insulating

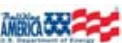

\section{Insulation Types}

\section{Classroom Exercise}

Name the insulation

What is the R-value per inch?

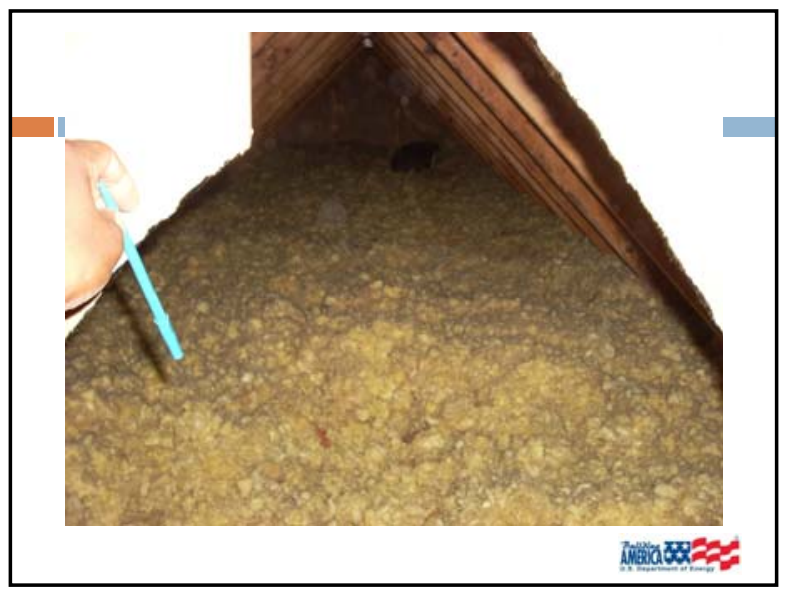



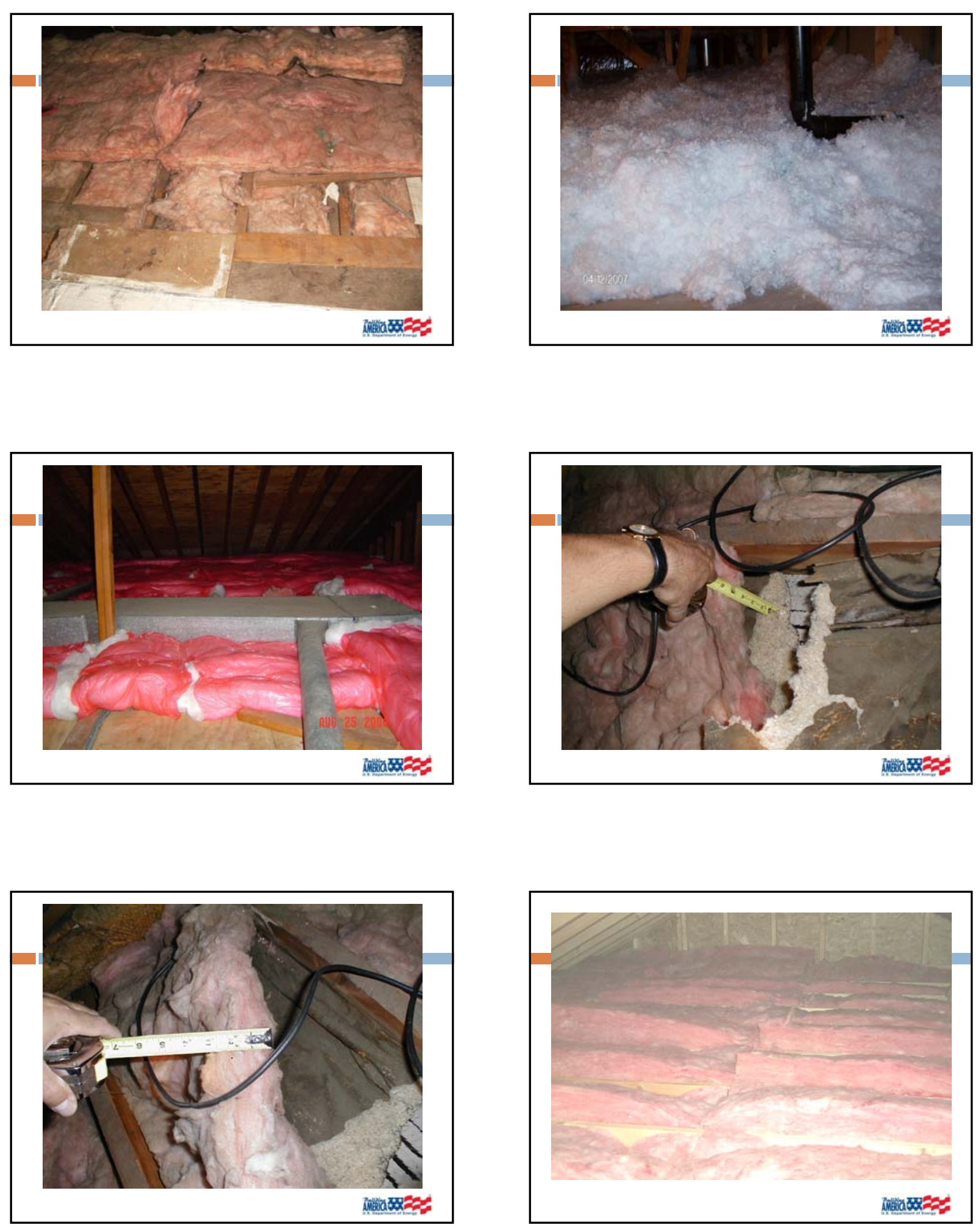

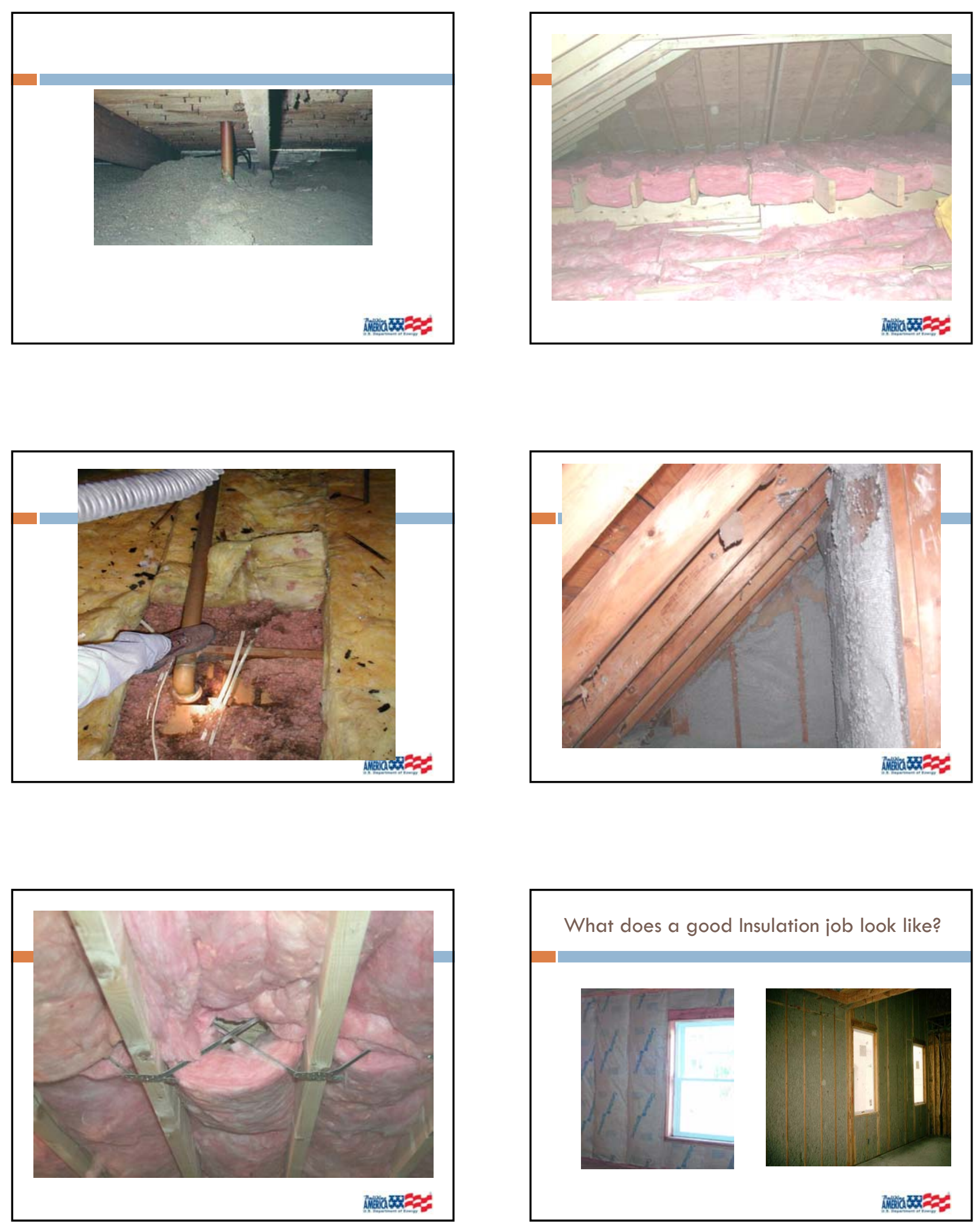


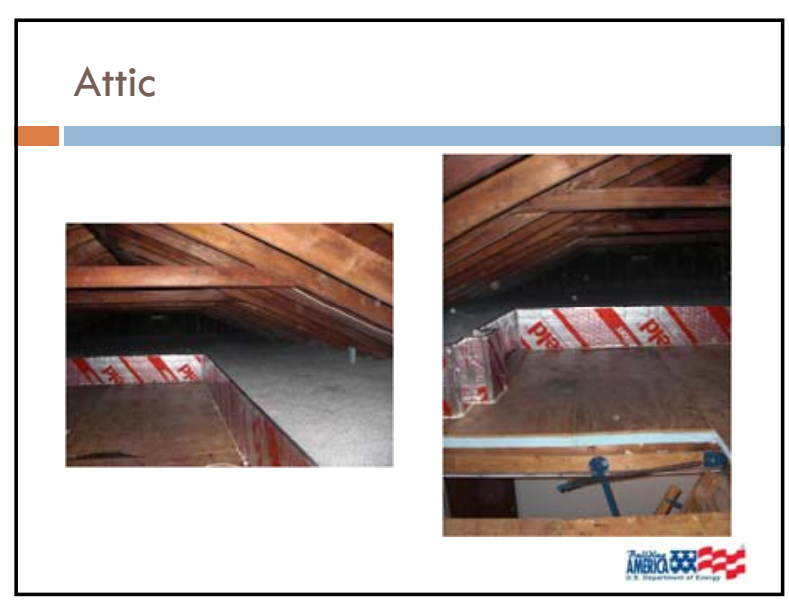

\section{Insulating Crawl Spaces}

To vent, or not to vent. That is the question.

Code used to mandate venting crawl spaces, in order to remove moisture

$\square$ But....usually the opposite occurs

$\square$ Why?

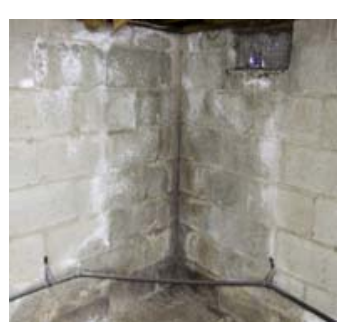

\section{Insulating Crawl Spaces}

$\square$ Rigid foam board

$\square$ High density spray foam

$\square$ Rockwool

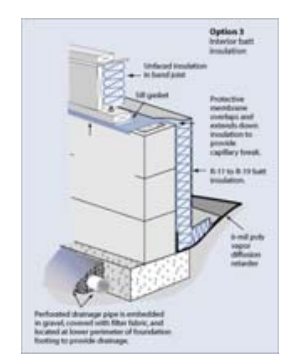

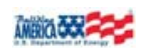

\section{Attic Hatches}

$\square$ One of the weakest points in the thermal envelope

$\square$ Gasket opening

$\square$ Insulate with Rigid Foam

$\square$ Add drywall or plywood for weight

\section{Insulating Crawl Spaces}

$\square$ Crawl Spaces generally should be unvented, conditioned areas

$\square$ Vapor Barrier over dirt floors

- Overlapped 6" at seams, taped or sealed

$\square$ Ran at least 6 " up the wall and sealed or taped

$\square$ Walls insulated to R-10 minimum

$\square$ Conditioned air supply sized to deliver at a rate of $1 \mathrm{cfm} / 50 \mathrm{ft} 2$ of under-floor area

$\square$ Remove all debris

\section{Insulating Crawl Spaces}

$\square$ Sometimes it is better to exclude crawls from energy envelope

$\square$ High water

table/standing water

$\square$ Insulate $c / s$ ceiling

$\square$ Air sealing is critical

$\square$ Seal and insulate ducts

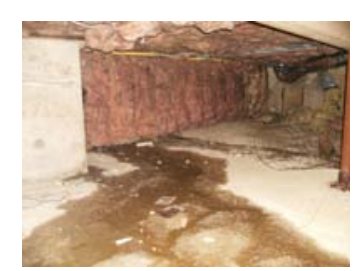

Tution 


\section{Knee Wall Areas}

Knee wall areas can either be brought into conditioned space or excluded from conditioned space

Insulate roof rafters to bring into conditioned space

Insulate walls and floor to exclude from conditioned space

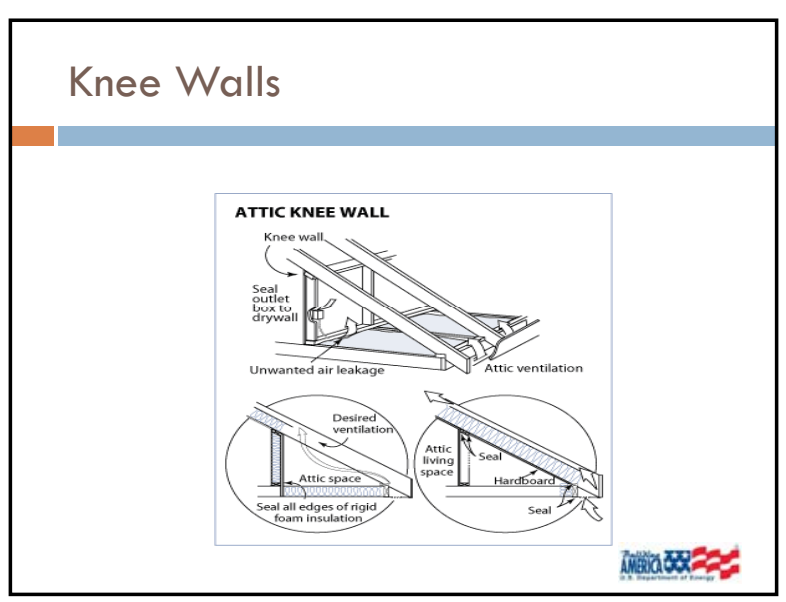

R-value vs. U-value $\left(\mathrm{Btu} / \mathrm{h} \cdot \mathrm{ft}^{2}{ }^{\circ} \mathrm{F}\right)$

$$
\text { U-value }=1 \div \text { R-value }
$$

Typically:

$\square \mathrm{U}$-values are used to rate window performance

$\square$ U-values are also used in heat loss calculations

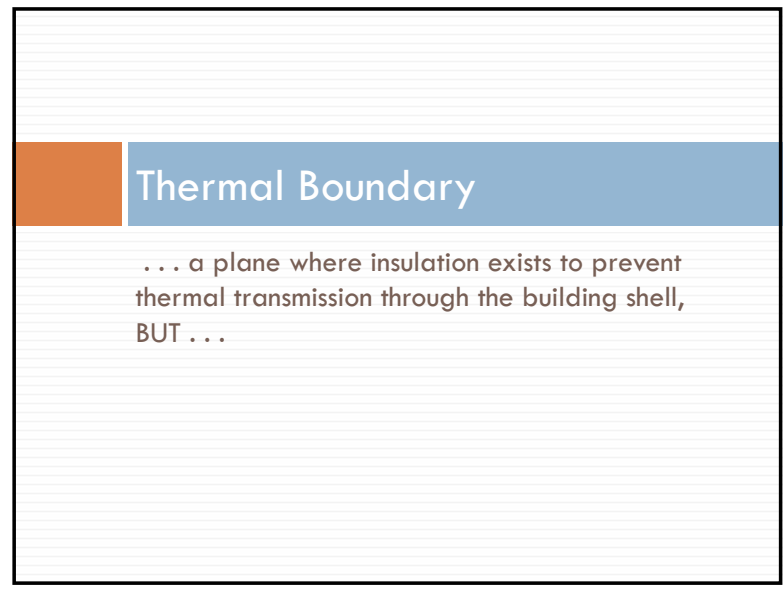

NFRC Label

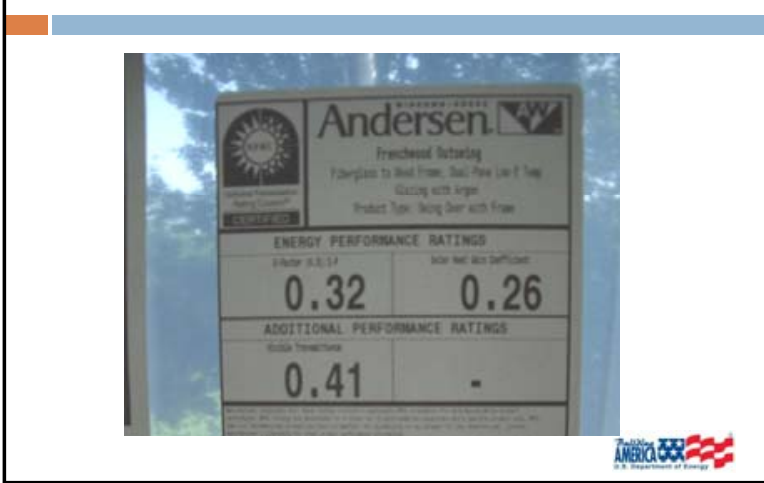

\section{Thermal Boundary}

$\square$ Type of insulation

$\square$ Amount of insulation (thickness and $\mathrm{ft}^{2}$ )

$\square$ Quality of installation (good, fair, poor)

$\square$ Is insulation protected from wind-washing?

$\square$ Is insulation protected from moisture?

What is the conditioned boundary?!!!! $\square$ Location of insulation in the building shell 

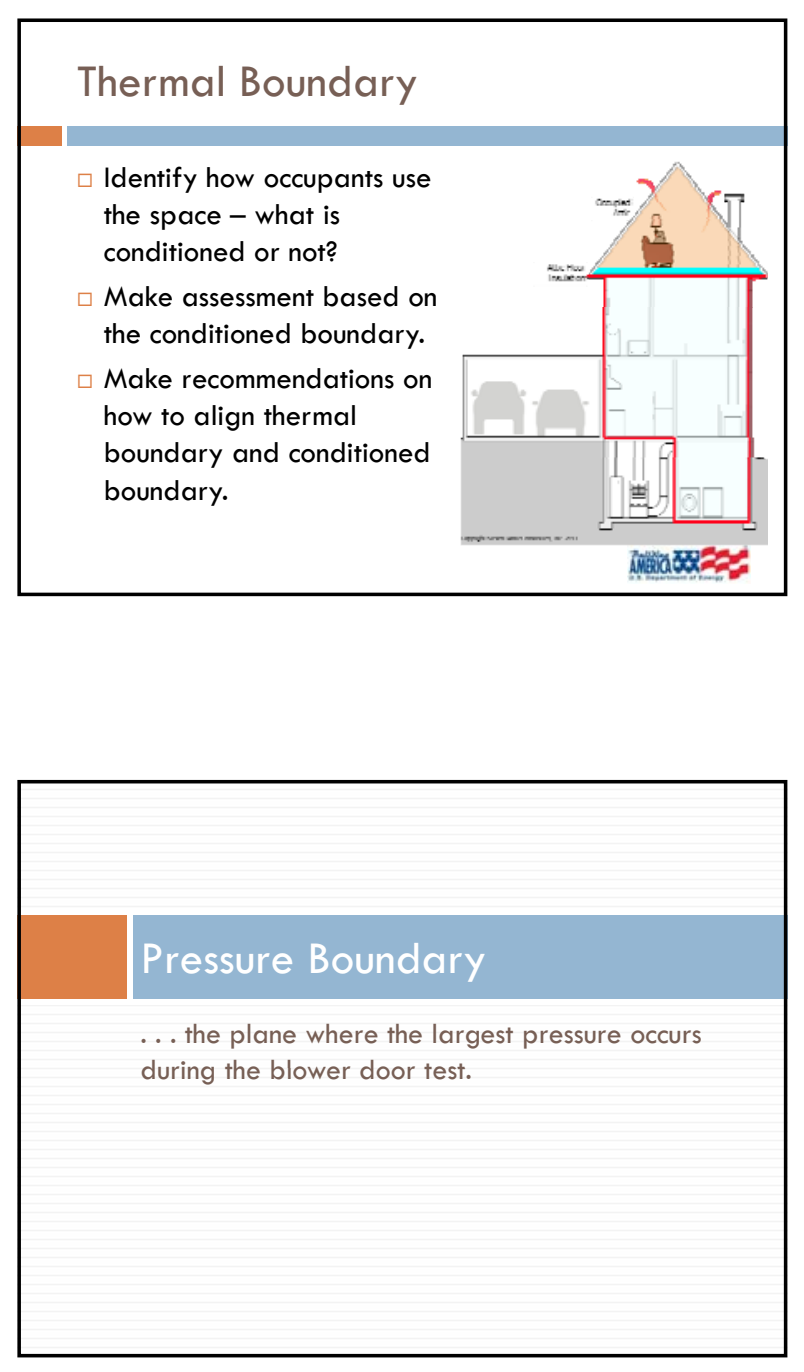

\section{Thermal and Pressure Boundaries}

$\square$ The two boundaries work together to manage energy, moisture, and comfort

$\square$ Energy Control $=\$ \$ \$$ saved

$\square$ Moisture Control = building durability

$\square$ Comfort Control $=$ happy customers

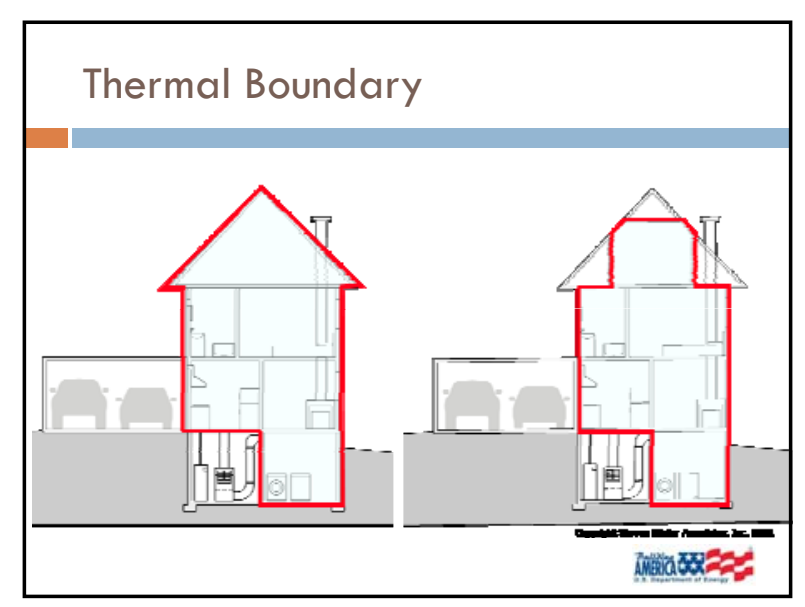

\section{Pressure Boundary}

$\square$ In order to control infiltration and exfiltration, the pressure boundary must be continuous.

$\square$ For maximum effectiveness, the pressure boundary and thermal boundary should be in the same plane.

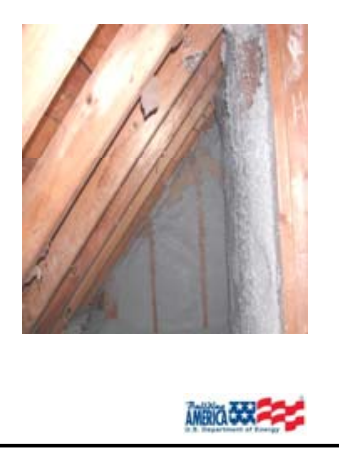

\section{Thermal and Pressure Boundaries}

$\square$ To function properly and protect the home, they must be:

$\square$ Continuous (no gaps)

$\square$ Aligned with each other 


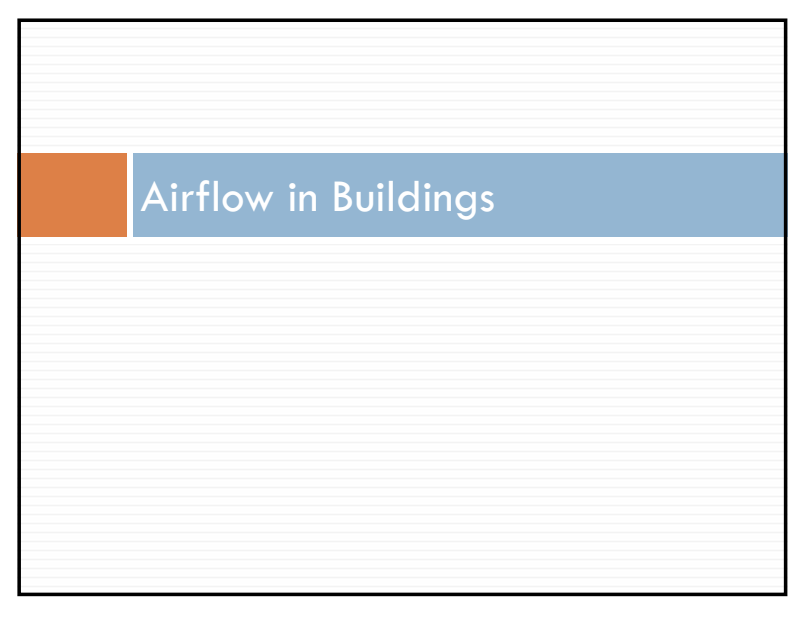

\section{Airflow in Buildings}

3 Main driving forces

$\square$ Stack effect

$\square$ Mechanical effect

$\square$ Wind effect

\section{Stack Effect}

Stack Effect is the term used to describe air movement in heated buildings:

warm air rises and escapes from holes high in the building while cold air is drawn in through holes low in the building

1 CFM out $=1$ CFM in

\section{Airflow in Buildings}

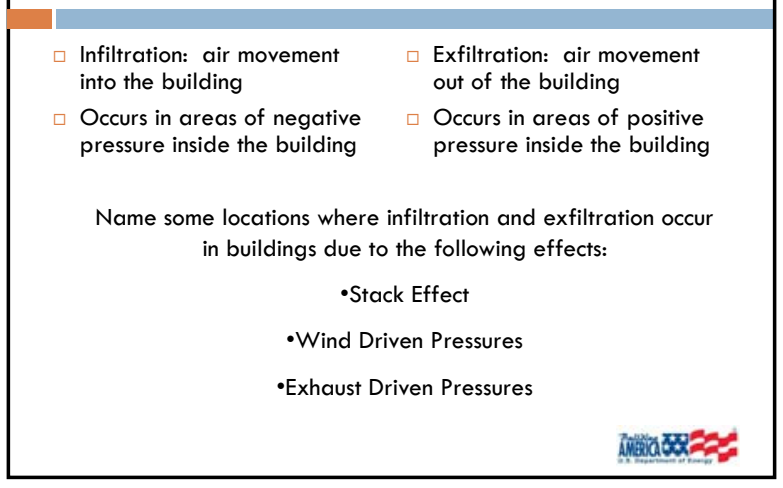

\section{Air Flow in Buildings}

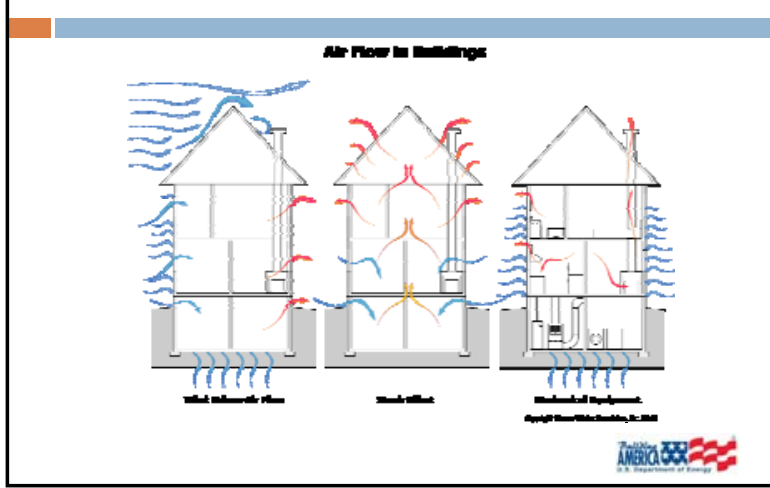

\section{Stack Effect}

Stack Effect is the term used to describe air movement in heated buildings:

warm air rises and escapes from holes high in the building while cold air is drawn in through holes low in the building 


\section{Exhaust Appliances}

Exhaust appliances cause depressurization of the living space

$\square$ Venting of combustion appliances can have the same effect

$\square$ When the house is depressurized, even at small pressures, infiltration will occur

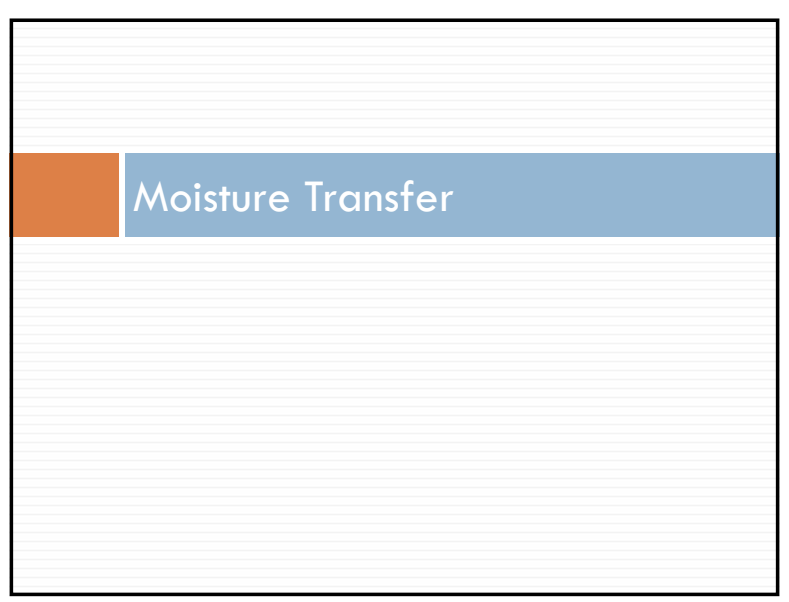

\section{Moisture Transport}

Moisture moves around buildings in all of the following ways:

$\square$ Bulk moisture transfer (including capillary action through porous materials)

$\square$ Diffusion

$\square$ Airborne moisture movement

$\square$ Which one do you think causes the most problems in homes?

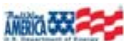

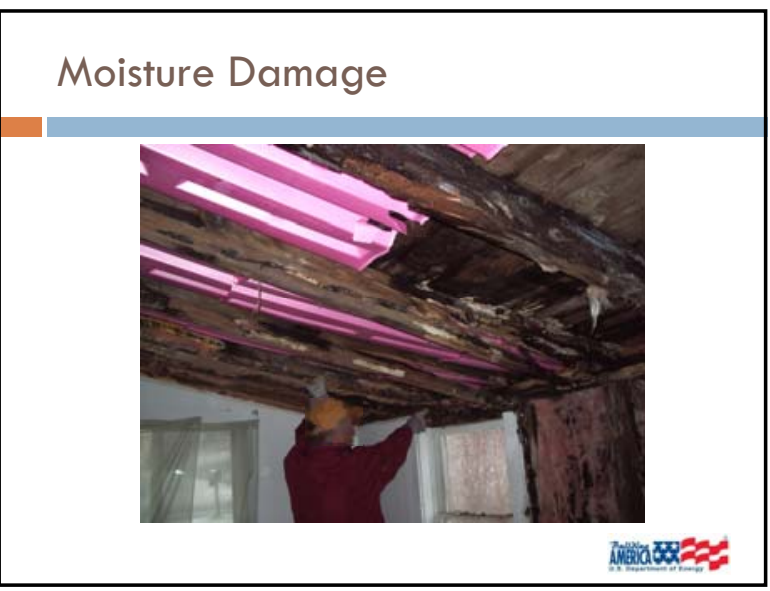

\section{Airborne Moisture}

$\square$ \#1 moisture-related problem for building science professionals

$\square$ Moisture gets into attics by stack effect (how else?)

$\square$ Moisture gets into walls by:

$\square$ Pressurization in heating season

$\square$ Depressurization in cooling season 


\section{Airborne Moisture - Control}

Reduce/eliminate sources - fix drainage around building, fix leaks into building

$\square$ Properly ventilate high moisture spaces - kitchens, baths, laundry

$\square$ Use whole-house mechanical ventilation - eliminate moisture from people, pets, etc.

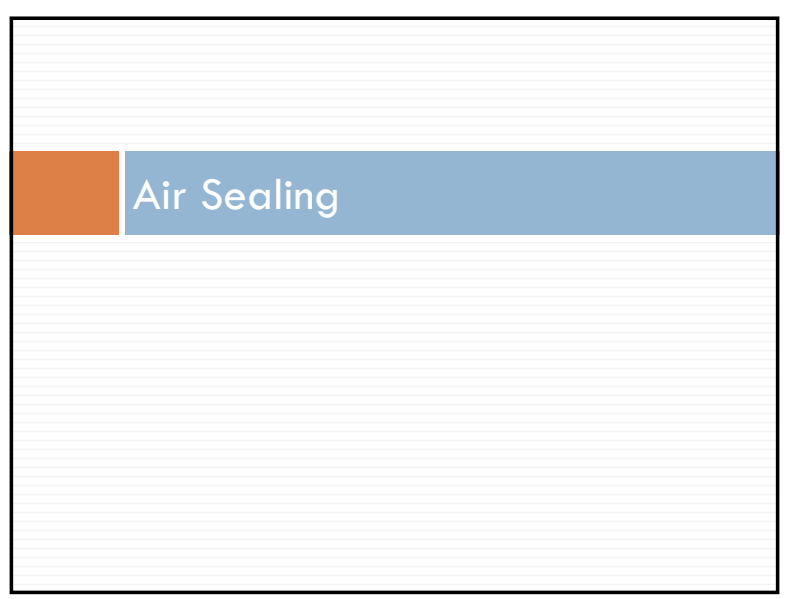

\section{Air Sealing Priorities}

Why Air Seal?

$\square$ Comfort

$\square$ Efficiency

$\square$ Moisture

$\square$ Indoor air quality (IAQ)

\section{Attic Air Sealing}

$\square$ Plumbing and electrical penetrations

$\square$ Chimneys and Vents

$\square$ Top plates

$\square$ Recessed lights

$\square$ Dropped soffits and ceilings

$\square$ Attic access

$\square$ Knee-wall areas

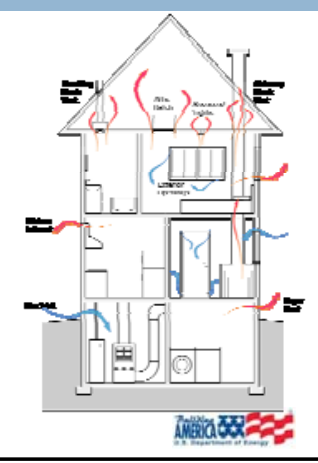

\section{P \& E Penetrations}
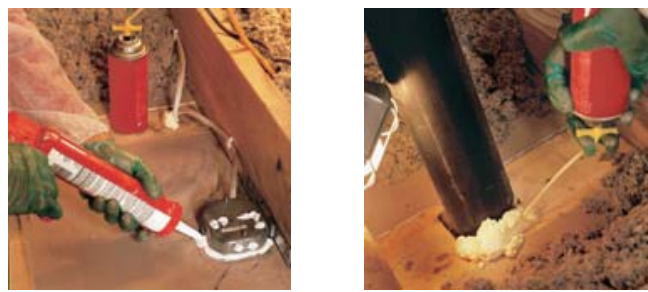

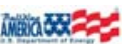




\section{Chimneys and Flue Vents}
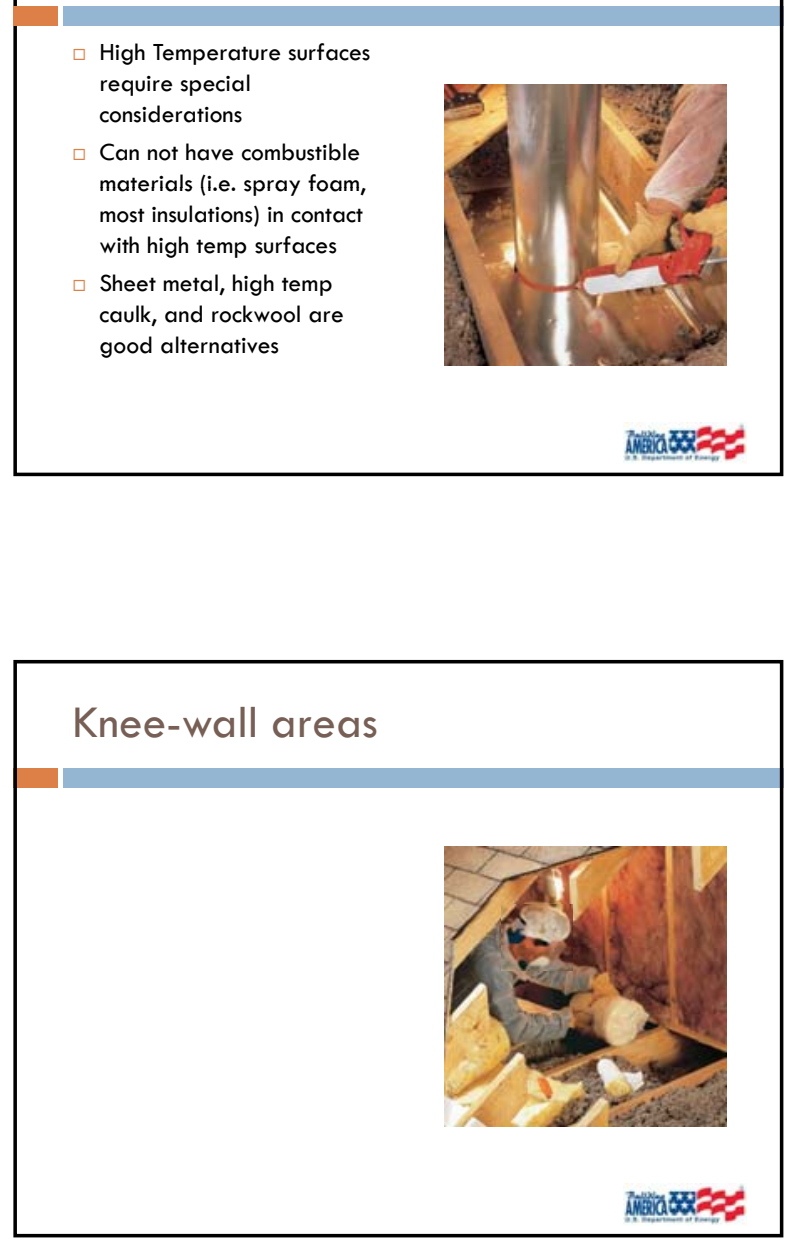

\section{Rim Joists/Exterior Penetrations}

\section{$\square$ Along the gap} between the sill plate and foundation

$\square$ Top and Bottom of each rim joist bay

$\square$ All electrical, water, or gas penetrations and any venting ducts that pass to the outside

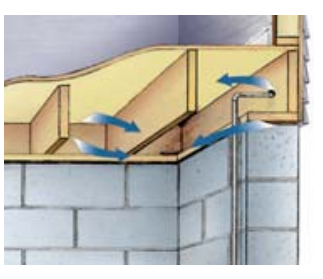

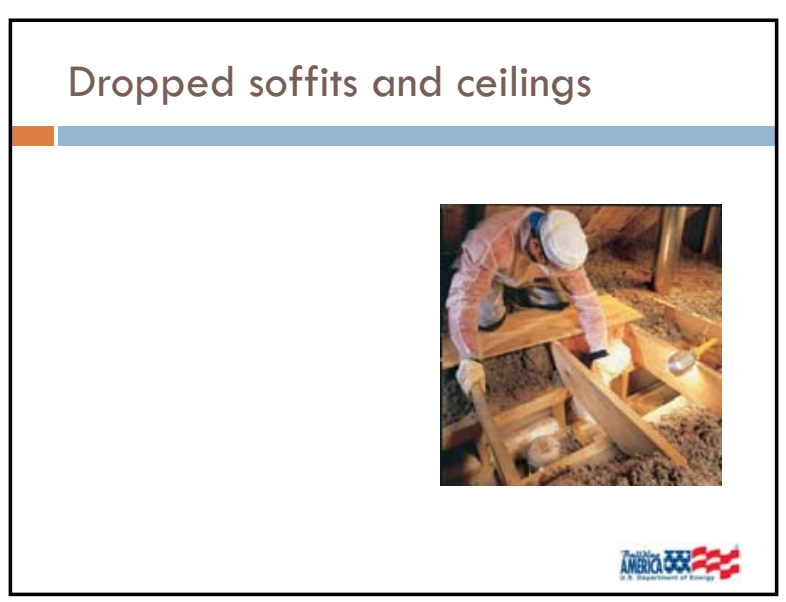

Basement/Crawl Space Sealing

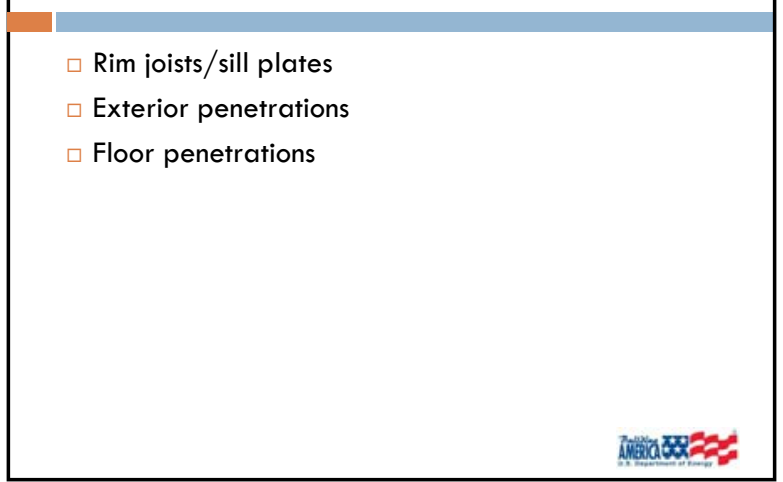

Floor Penetrations

Electrical and plumbing penetrations

$\square$ Under tubs and showers

$\square$ HVAC duct penetrations 


\section{Main House Air Sealing}

Caulk Baseboards

$\checkmark$ Weather-strip doors and windows

$\square$ Caulk around door and window trim

$\square$ Foam plumbing penetrations beneath sinks

$\square$ Gasket electrical outlets

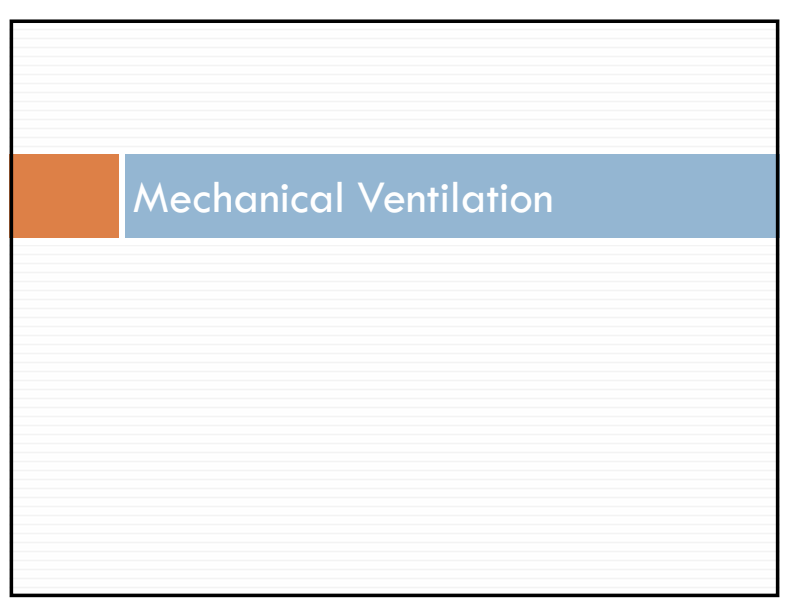

Mechanical Ventilation System Types

- Exhaust Only

Supply Only

Balanced - Heat or Energy Recovery

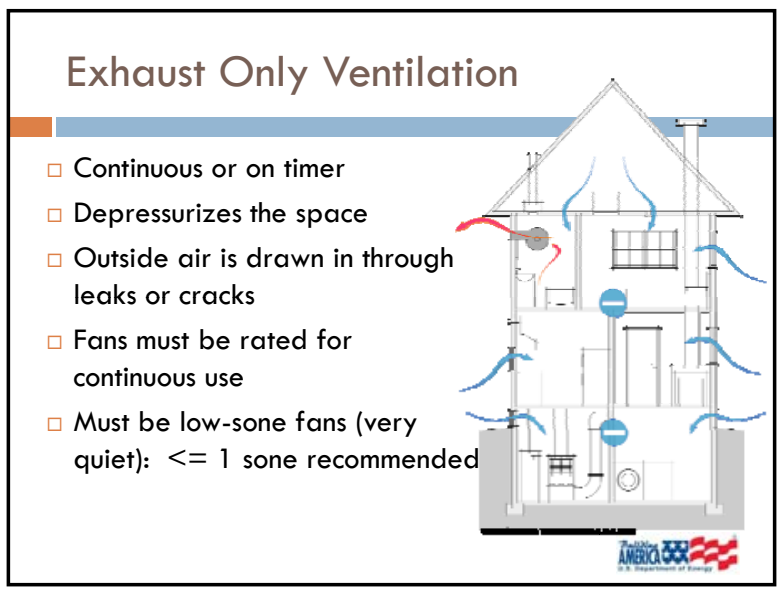

\section{Supply Only Ventilation}

Uses fresh air duct connected to return ductwork

Supplies fresh air when air handler is running

$\square$ Pressurizes the space

Forces pollutants out through leaks in the building shell

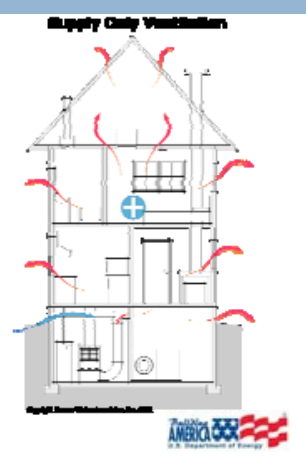

\section{Balanced Ventilation}

$\square$ Heat Recovery

$\square$ transfer heat between indoor and outdoor air

$\square$ will cool incoming air in summer

$\square$ will heat incoming air in winter

$\square$ use if humidity is always to be removed or humidity levels on both sides are favorable

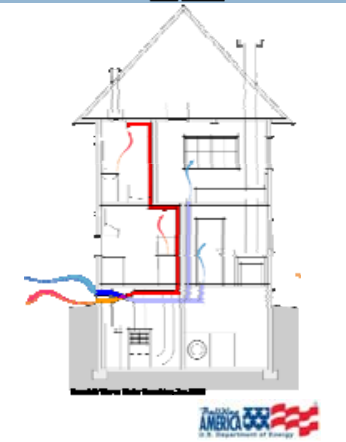




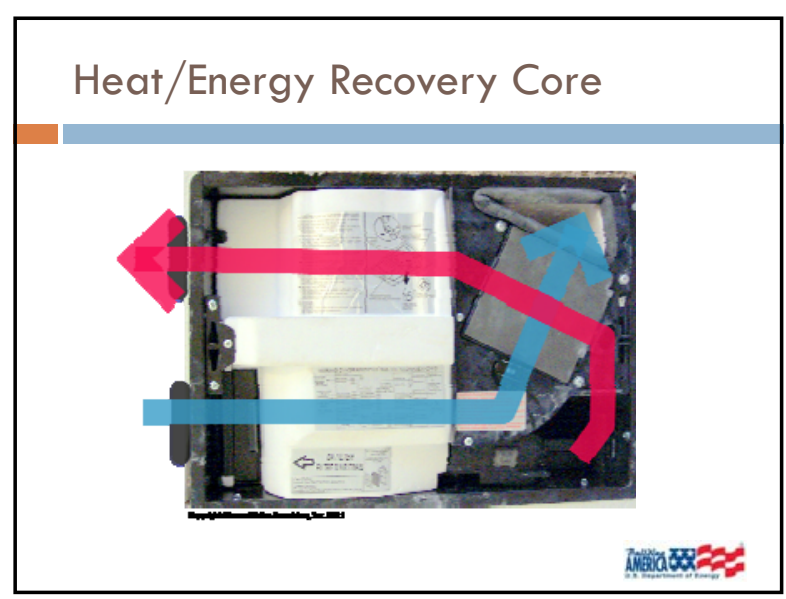

\section{Types of Ventilation - Pro's \& Con's}

\begin{tabular}{|c|c|c|c|c|}
\hline & Exhaust Only & Supply Only & HRV & ERV \\
\hline Pro's & $\begin{array}{l}\text { - Inexpensive Install } \\
\text {-Easy to Retrofit } \\
\text { - Low Maintenance } \\
\text { - Low Energy Fan }\end{array}$ & $\begin{array}{l}\text { - Inexpensive Install } \\
\text {-Easy to Retrofit } \\
\text {-Low Maintenance } \\
\text { - Air is filtered }\end{array}$ & $\begin{array}{l}\text { - High Energy Savings } \\
\text { - Low Maintenance } \\
\text { - Air is filtered } \\
\text { - Balanced pressures }\end{array}$ & $\begin{array}{l}\text {-High Energy Savings } \\
\text {-Air is filtered } \\
\text {-Humidity Control } \\
\text { - Balanced pressures }\end{array}$ \\
\hline Con's & $\begin{array}{l}\text {-No heat recovery } \\
\text {-Can pull humid air } \\
\text { into building cavities }\end{array}$ & $\begin{array}{l}\text { - Use furnace fan - } \\
\text { high energy use } \\
\text { - No heat recovery } \\
\text { - Could push humid air } \\
\text { into building cavities }\end{array}$ & $\begin{array}{l}\text { - Expensive Install } \\
\text { - Hard to Retrofit } \\
\text { - Higher Energy Use } \\
\text { Fan } \\
\text {-Condensate Drain } \\
\text { Needed }\end{array}$ & $\begin{array}{l}\text {-Expensive Install } \\
\text { - Hard to Retrofit } \\
\text { - High Maintenance } \\
\text { - Condensate Drain } \\
\text { Needed }\end{array}$ \\
\hline \multirow[t]{2}{*}{$\begin{array}{l}\text { Best } \\
\text { Use }\end{array}$} & $\begin{array}{l}\text { - No outdoor pollutants } \\
\text { - Outdoor humidity is } \\
\text { not a problem }\end{array}$ & $\begin{array}{l}\text { - High outdoor } \\
\text { pollutants - incoming } \\
\text { air should be filtered }\end{array}$ & $\begin{array}{l}\text {-Areas where indoor } \\
\text { humidity is too high } \\
\text {-Areas where } \\
\text { humidity is not a } \\
\text { concern }\end{array}$ & $\begin{array}{l}\text {-Areas of high outdoor } \\
\text { humidity } \\
\text {-Areas with low indoor } \\
\text { humidity }\end{array}$ \\
\hline & & & & Ansiacos 5 \\
\hline
\end{tabular}

\section{Using a Blower Door}

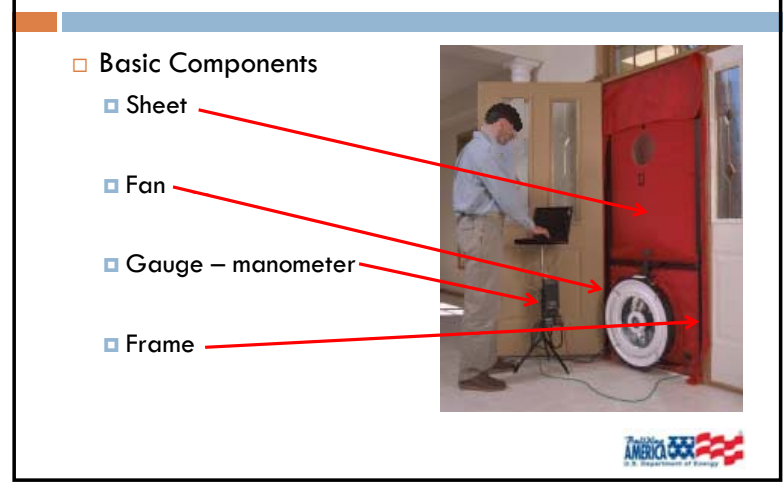

\section{Balanced Ventilation}

\section{$\square$ Energy Recovery}

$\square$ transfers heat and moisture between indoor and outdoor air,

$\square$ will cool incoming air in summer and heat it in winter

$\square$ moisture moves from air stream with higher levels to air stream with lower levels of moisture

$\square$ use if:

n hot humid outside and you want to remove humidity from incoming air

a cold dry outside and you want to return all or some of the humidity to the space

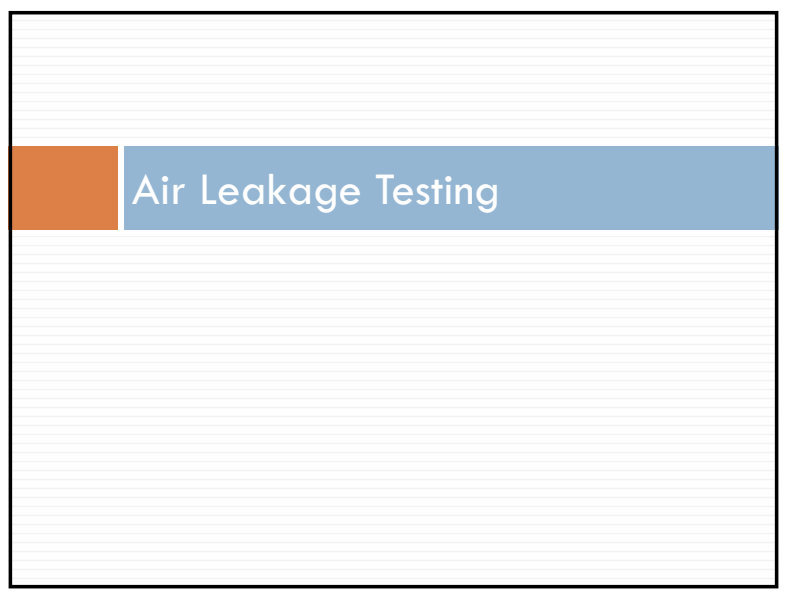

\section{Using a Blower Door}

\section{$\square$ House Preparation}

$\square$ Open doors to conditioned space

Make sure all registers are open and uncovered

$\square$ Turn off ALL fans.

$\square$ Tape off any openings for mechanical ventilation that runs automatically and continuously.

$\square$ Turn heating and air conditioning systems off.

$\square$ Turn gas water heating equipment to pilot. Leave your car keys.

$\square$ Turn off the emergency switch for oil \& gas equipment. 


\section{Using a Blower Door}

House Preparation (cont.)

$\square$ Close fireplace dampers and remove or cover ashes.

$\square$ Close and lock all windows including storms.

$\square$ Close adjustable trickle \&/or through the wall vents.

- Seal evaporative cooler openings if a cap is used.

口 Fill plumbing traps with water if air is coming out.

- Seal window air conditioners that are removed in winter.

- If you suspect asbestos is present, do not do a blower door.

- When finished, remove tape, put thermostats back to original settings and turn on heating and hot water.

\section{Using a Blower Door}

$\square$ Check your readings against:

$\square$ Typical flows in table on Quick Guide

$\square$ Against pressure/flow tables in back of manual

\begin{tabular}{|l|r|}
\hline Fan Configuration & $\begin{array}{c}\text { Flow Range (cfm) } \\
\text { for Model 3 Fan }\end{array}$ \\
\hline Open (no Flow Ring) & $6,300-2,430$ \\
\hline Ring A & $2,800-915$ \\
\hline Ring B & $1,100-300$ \\
\hline Ring C & $330-85$ \\
\hline
\end{tabular}

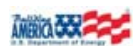

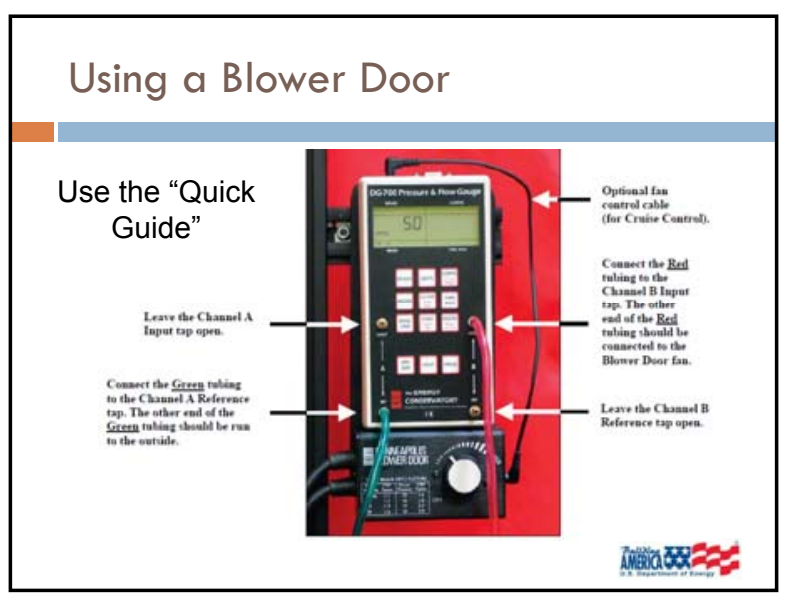

\section{Using a Blower Door}

$\square$ Blower door tells you:

$\square$ Air changes per hour (ACHn) - How many times per hour the air in the house is exchanged with outside air

$\square$ Where major leaks are

口 If unconditioned buffer zones are inside or outside of the house

$\square$ Areas you should concentrate on when air sealing

- High \& low holes

- Biggest holes

$\square$ If mechanical ventilation should be added

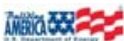

\section{Building Airtightness Standard}

\section{If $\mathrm{ACHn}<0.35$ then mechanical ventilation is} required according to ASHRAE 62.2.

How do you calculate $\mathrm{ACHn}$ ?

$\mathrm{ACHn}=\mathrm{cfm} @ 50 \times 60 \mathrm{~min} / \mathrm{hr} \div$ (Volume $\times \mathrm{n}$-Factor $)$

\section{N-factor and Height Correction}

Table 4.1 - LBL n-Factor for Boulder, CO (Zone 2)

\begin{tabular}{|l|c|c|c|c|}
\cline { 2 - 5 } \multicolumn{1}{c|}{} & \multicolumn{4}{c|}{ \# of Stories } \\
\hline Wind Exposure & $\mathbf{1}$ & $\mathbf{1 . 5}$ & $\mathbf{2}$ & $\mathbf{3}$ \\
\hline Well-shielded & 22.2 & 20.0 & 17.8 & 15.5 \\
\hline Normal & 18.5 & 16.7 & 14.8 & 13.0 \\
\hline Exposed & 16.7 & 15.0 & 13.3 & 11.7 \\
\hline
\end{tabular}




\section{Example: Calculate $\mathrm{ACHn}$}

House Description: $1000 \mathrm{ft}^{2}$ house, 8' ceilings, 2 stories, 3 bedrooms, blower door reading is 500 cfm@50 pascals, normal exposure

$\square$ Step 1: Calculate Volume $1000 \mathrm{ft}^{2} \times 8^{\prime}=8000 \mathrm{ft}^{3}$

$\square$ Step 2: Determine n-Factor $=14.8$

$\square$ Step 3: Calculate $\mathrm{ACHn}$

$(500 \times 60) \div(8000 \times 14.8)=0.25 \mathrm{ACHn}$

Needs mechanical ventilation

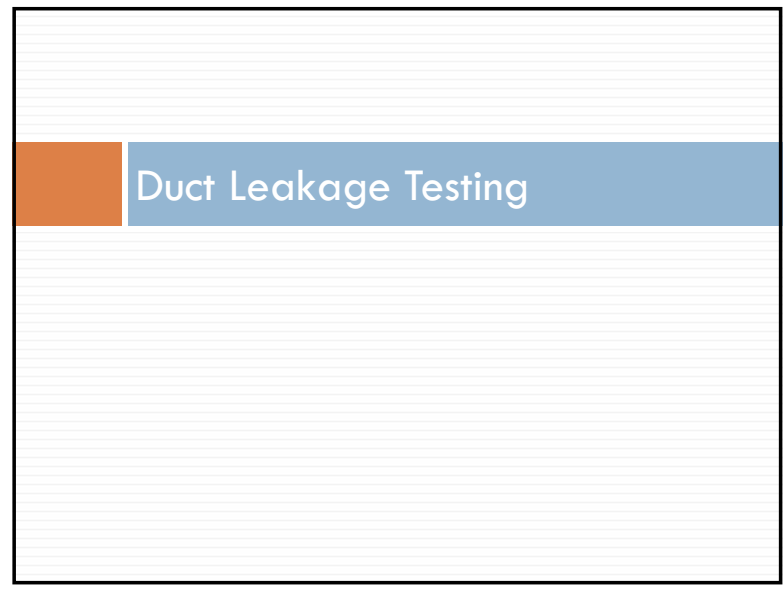

\section{Duct Leakage Testing}

$\square$ Configure the house for an air leakage test

$\square$ Determine if the air handler is inside or outside the conditioned space

Remove the system air filter.

- Select an appropriate location - at air handler or return closest to air handler

Set up the pressure hoses - if gauge is "outside" the conditioned area, run hose to the conditioned space

Seal all supply and return registers
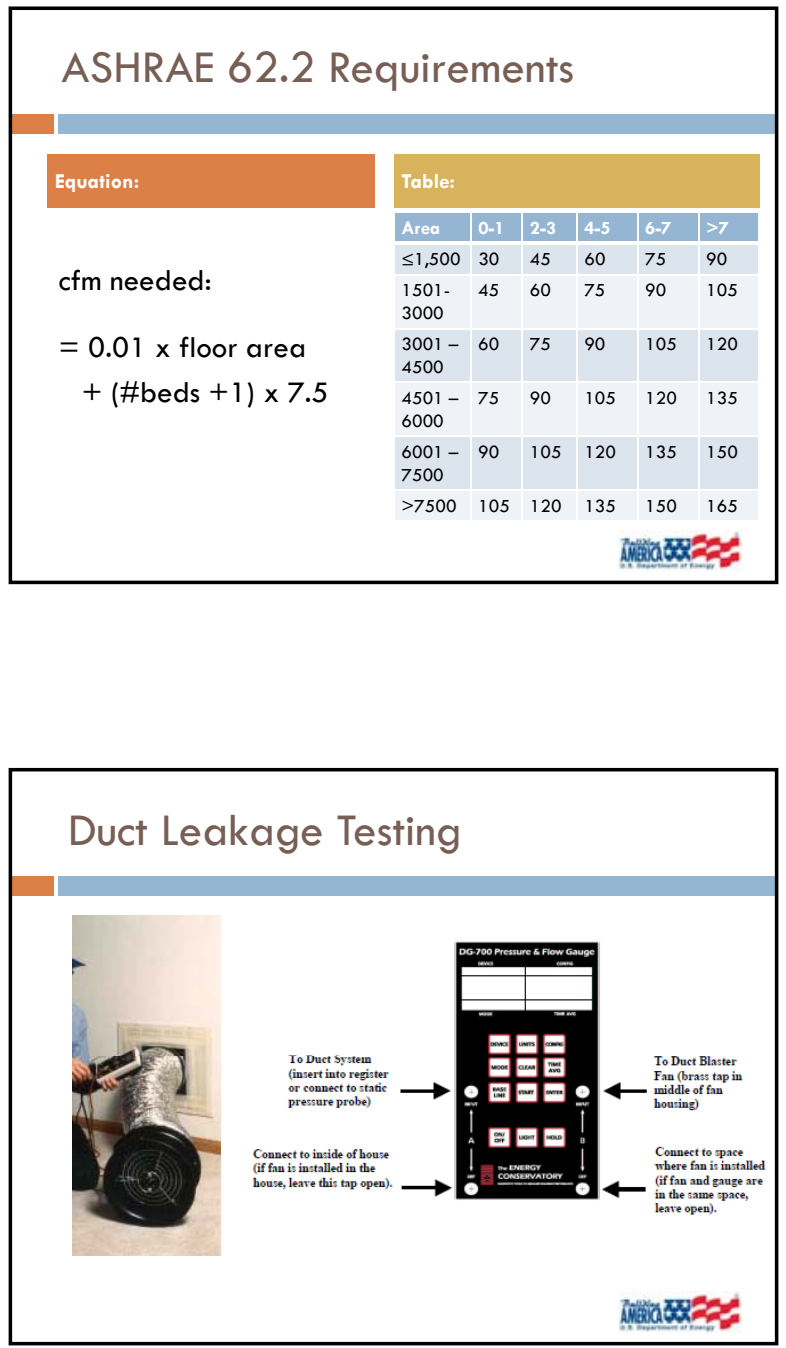

\section{Duct Leakage Testing}

$\square$ Open unconditioned zones to outside as much as possible.

$\square$ Using the blower door, pressurize the house to 25 Pascals.

$\square$ Pressurize the duct system until the pressure in the supply duct is 0 .

$\square$ Record testing equipment fan pressure and ring used

$\square$ Record the duct blaster fan airflow. This is your duct leakage to outside.

An: 


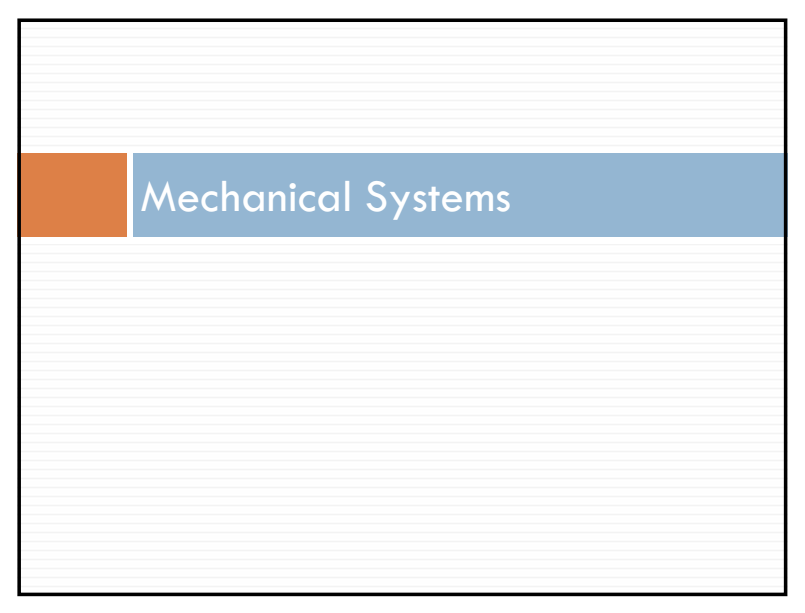

\section{Heating System Efficiency}

$\square$ Steady-State Efficiency:

$\square$ can be measured directly

$\square$ Indicates how efficiently the burner is burning

$\square$ Annual Fuel Utilization Efficiency (AFUE):

$\square$ Usually appears in manufacturer's literature

$\square$ Includes jacket, cycling, and flue losses

$\square$ Seasonal Efficiency:

$\square$ Includes distribution efficiency and AFUE

\section{Combustion Science}

$\square$ Elements needed for combustion

- Fuel - gas, oil, wood, propane, etc.

$\square$ Oxygen

$\square$ Heat Source

$\square$ By-products

$\square$ Water $\left(\mathrm{H}_{2} \mathrm{O}\right)$

$\square$ Carbon Dioxide $\left(\mathrm{CO}_{2}\right)$

$\square$ Incomplete combustion leads to Carbon Monoxide (CO)

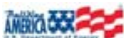

Heating and DHW System Identification

$\square$ Identify the fuel

$\square$ Identify the venting type

$\square$ Identify the distribution type

$\square$ Determine the efficiency
Gas Furnace, Atmospherically Vented

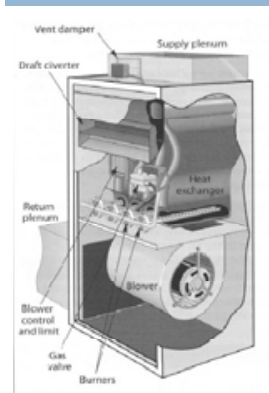

Burners can be viewed directly by removing cabinet cover

$\square$ Relies on air from mechanical room for the burner (combustion air) and for draft (dilution air)

\section{Sealed-Combustion Gas Furnace}

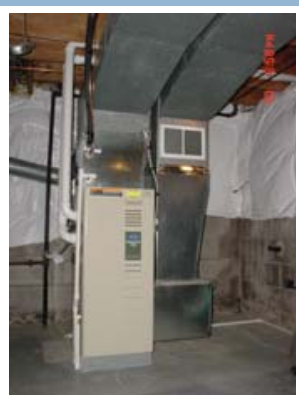

$\square$ What is the difference between "direct-vent" and "sealed combustion"? 

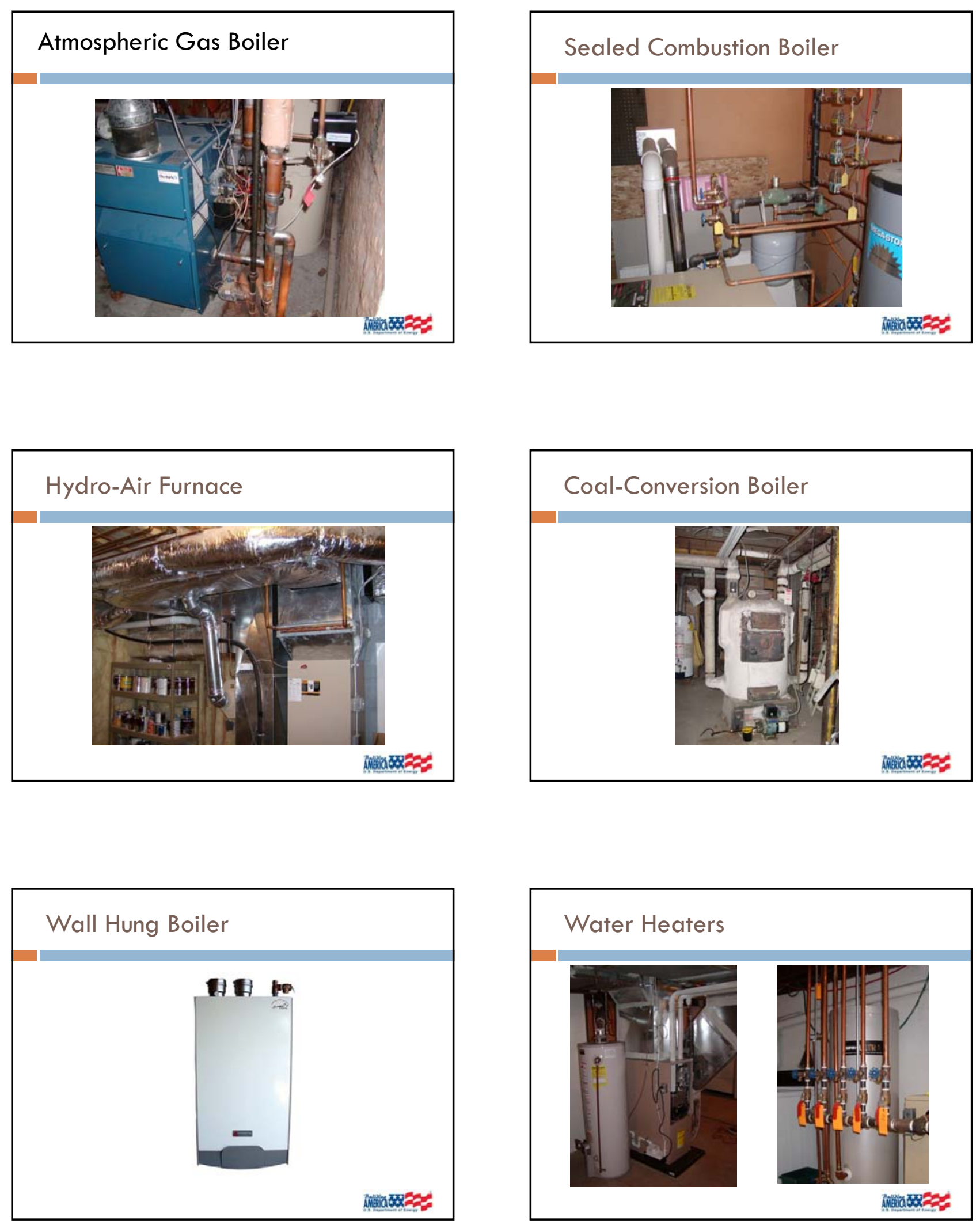


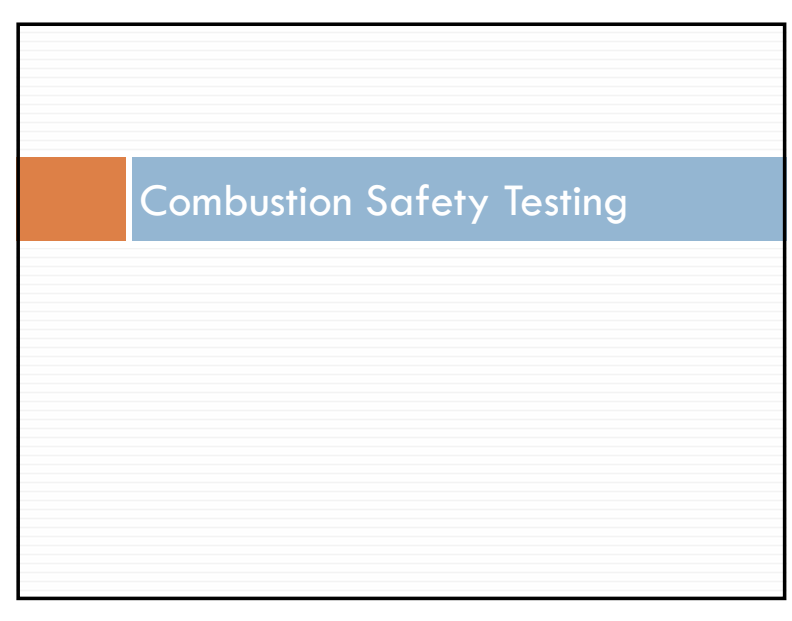

\section{Common Causes of $\mathrm{CO}$}

$\square$ Not enough combustion air

$\square$ Incorrect gas pressure

$\square$ Improper venting

$\square$ Flame Impingement

$\square$ Dirty/clogged burners

\section{Carbon Monoxide}

- Carbon monoxide occurs when there is "incomplete combustion" in the appliance

$\square$ Typically, this happens when the air/fuel mixture is improper

$\square$ Oxygen deprivation can also occur when the burner flames impinge on a solid surface

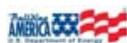
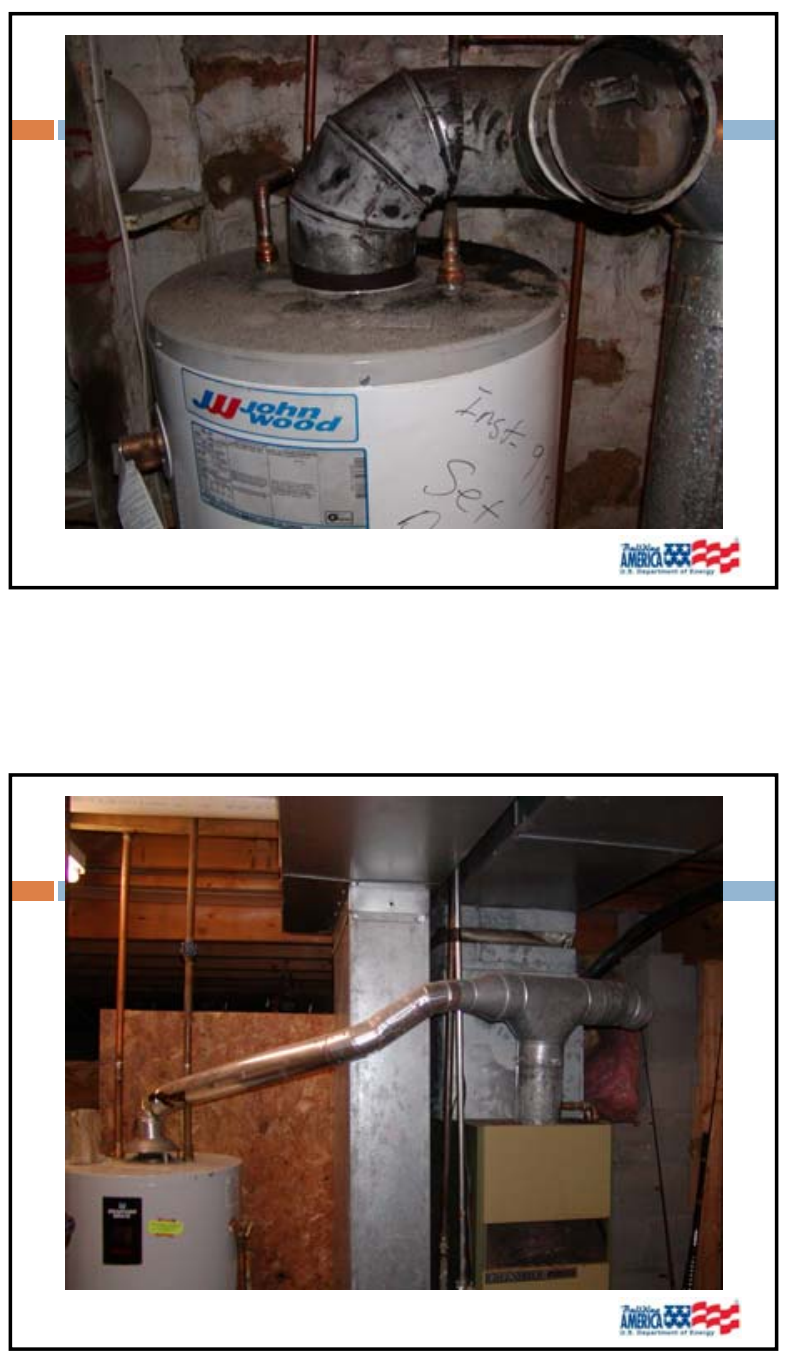


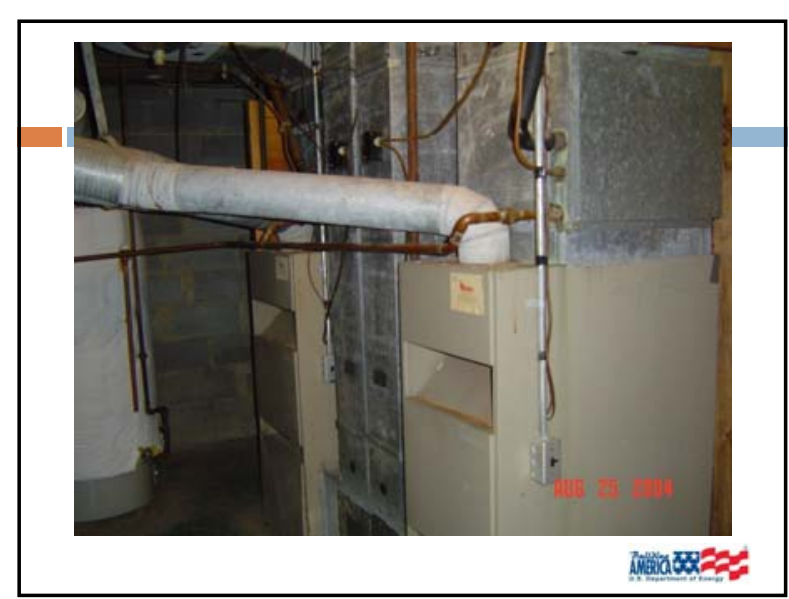

\section{Other Sources of CO}

Don't forget that CO can be produced in other parts of the home, including:

$\square$ Woodstoves/fireplaces

$\square$ Attached garages

$\square$ Electric stoves on the cleaning cycle

\section{Why is CO Dangerous?}

$\square$ Hemoglobin normally bonds with oxygen and distributes $\mathrm{O}_{2}$ throughout your body.

$\square$ When $\mathrm{CO}$ is inhaled, it combines with hemoglobin with a bond that is 200 times stronger than its normal bond with $\mathrm{O}_{2}$.

$\square$ Carbon monoxide poisoning deprives your body's cells of oxygen.

\section{Worst Case CAZ Depressurization}

Set up the worst-case scenario combustion appliance zone (CAZ)

Measure the base pressure between the CAZ and outside Turn on all exhaust fans (don't forget dryers).

Determine if door closures make the CAZ pressure more negative, if so, keep them closed

Determine if operation of the air handler fan makes the CAZ more negative, if so, conduct test with fan on

Measure the worst-case negative pressure

\section{CO Detectors}

$\square$ A CO detector is recommended on every floor

$\square$ CO detectors shall be UL-2034 compliant and installed in accordance with manufacturer's recommendations

\section{Worst-case CAZ Depressurization}

$\square$ Use the correct manometer setup

$\square$ Use care on windy days

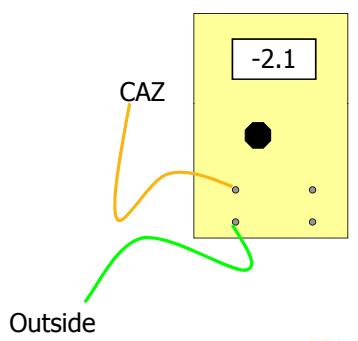

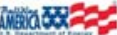




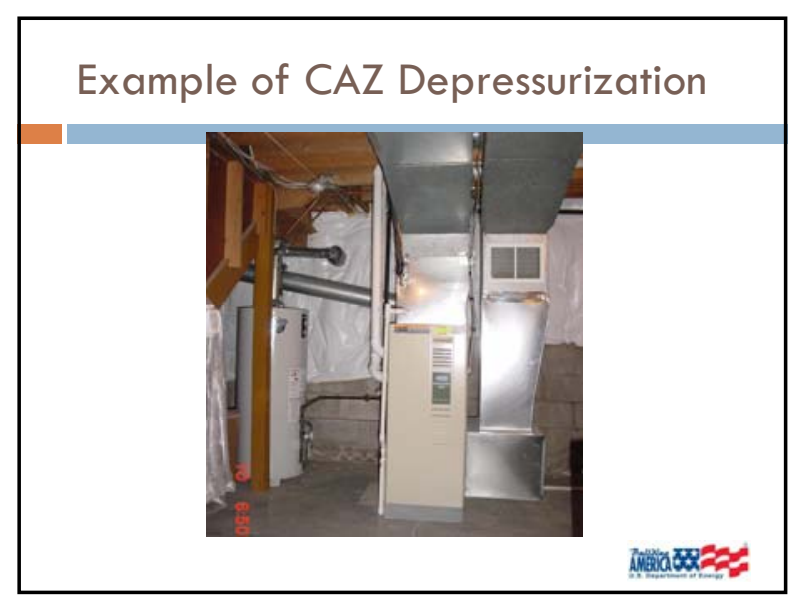

\section{Spillage}

$\square$ Check for spillage upon startup of combustion appliances

$\square$ Use stopwatch to record time elapsed before draft is established

$\square$ Use smoke around draft hood to verify spillage has ceased

$\square$ Use BPI standards to determine how to proceed

Check Draft Diverter for Signs of Spillage

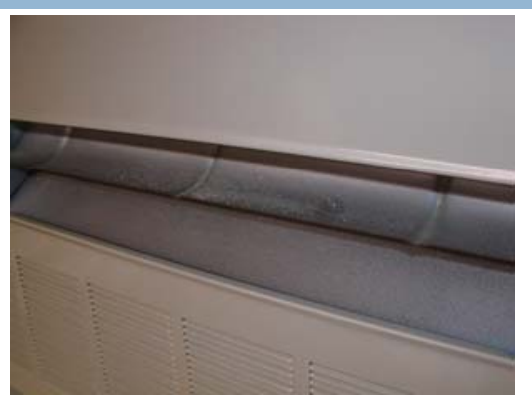

W.

\section{Spillage Test}

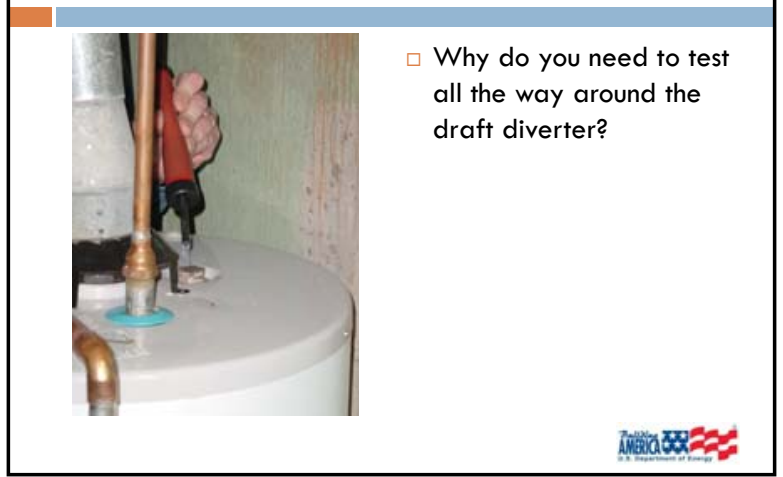

Turbulator Divides Flue Into 2 Chambers

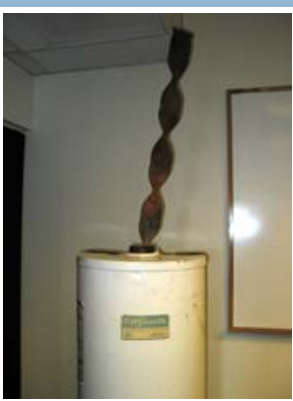

\section{Draft}

$\square$ Draft is measured approximately 12-18" downstream of the draft diverter

$\square$ Drill a $1 / 4$ " hole in the flue pipe and insert pressure probe or draft gauge

$\square 5$ Pascals $=0.02$ inches $\mathrm{H}_{2} \mathrm{O}$ (to convert, divide Pascals by 250) 


\section{Testing Multiple Appliances}

Always test the smallest Btu appliance first

Turn on larger appliance with smaller appliance already running and test them together

$\square$ Shut off both appliances and test the larger appliance alone

\section{Carbon Monoxide}

$\square$ CO Measurements should always be taken in "undiluted" flue gases (i.e. before the draft diverter)

$\square$ Use the charts provided in the BPI standards to determine appropriate procedures based on measurements

\section{Carbon Monoxide Testing Procedures}

$\square$ "Zero" the gauge by measuring outdoor levels as a baseline before testing inside the house.

$\square$ Ambient $\mathrm{CO}$ should be monitored throughout the entire combustion safety testing procedure

$\square$ If Ambient $\mathrm{CO}$ exceeds $35 \mathrm{ppm}$ at any time, the test should be stopped, appliances shut down, and the space ventilated before continuing

$\square$ The appliance should be adjusted/repaired prior to repeating the test

\section{"Natural" Conditions}

If an appliance fails the combustion safety tests under worst-case, the tests should be repeated under "natural" conditions

$\square$ Return all doors to their normal positions and turn off exhaust appliances, then repeat the tests

$\square$ Proceed as directed in the BPI standards

\section{Testing Appliances that are not} Atmospherically Vented

$\square$ All tests should be conducted on induced-draft or fanassisted units

$\square$ Use galvanized lag screw (or similar) long enough to go through both walls, to seal holes made in doublewalled flue pipe

$\square$ Do not drill holes in PVC flue pipe - if accessible, measure $\mathrm{CO}$ at the exhaust outlet

\section{Special Concerns with Furnaces}

$\square$ Check for flame interference by viewing the burner flames when the air-handler fan kicks on, if the flames change, this could be an indication of a problem (possibly a cracked heat exchanger)

$\square$ Wherever ductwork is present in the $C A Z$, take care to determine how duct sealing will effect the performance of the combustion appliances (creating negative or positive pressures in the zone) 


\section{CO Testing Gas Ovens}

Turn the oven on high $\left(500^{\circ} \mathrm{F}\right)$ and start a stopwatch Monitor ambient $\mathrm{CO}$ for first 5 minutes

Insert probe into "throat" (exhaust outlet) of the oven

$\square$ Monitor CO readings until they become steady and record the steady-state reading

$\square$ Use BPI standards to determine actions based on results

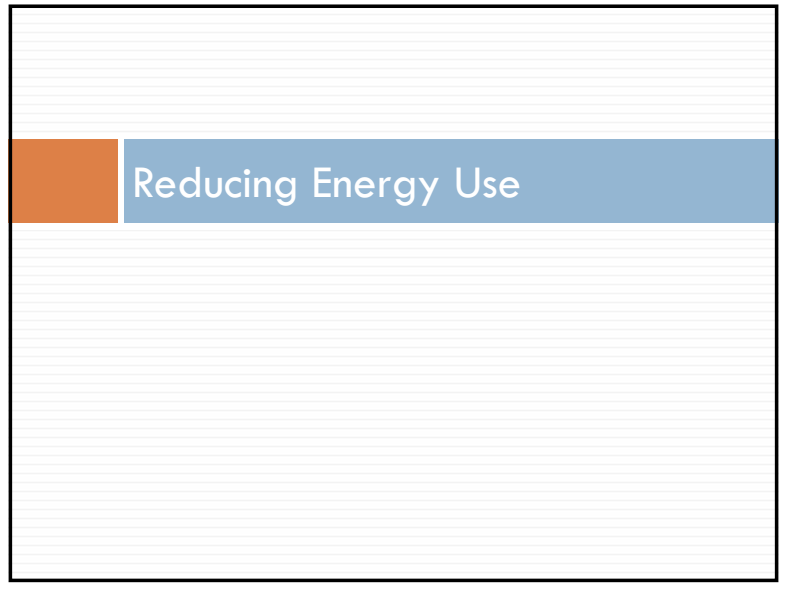

\section{Energy Saving Strategies}

\section{Energy Saving Strategies}

\section{$\square$ Minimize Loads:}

$\square$ Air sealing, insulation, duct sealing

also, things like shading in summer

$\square$ Reduce Consumption:

$\square$ Use higher efficiency equipment and appliances

$\square$ Reduce run times of lights and appliances, turn back thermostats 


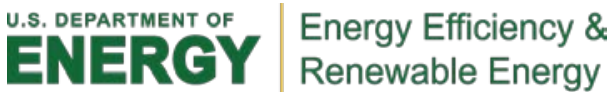

\section{Appendix D Contractor Training}




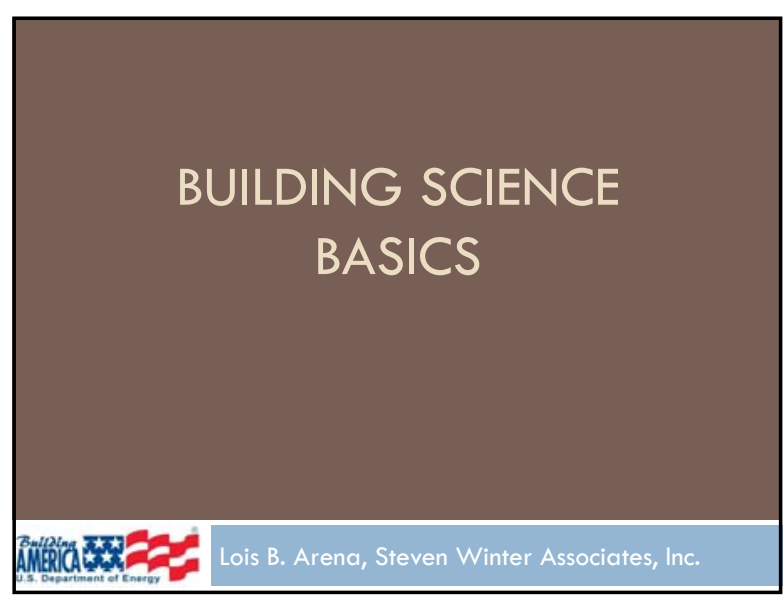

\section{House as a System Concept}

System Interaction Examples

- Adding insulation to an attic without air sealing could cause the roof to rot out.

- Installing a high efficiency furnace could cause the water heater to back draft.

- Air sealing the building could cause condensation on windows.
It applies to:

How air moves

$\square$ How heat is transferred

$\square$ How moisture migrates

$\square$ How heating and cooling create comfort

......convinced yet?
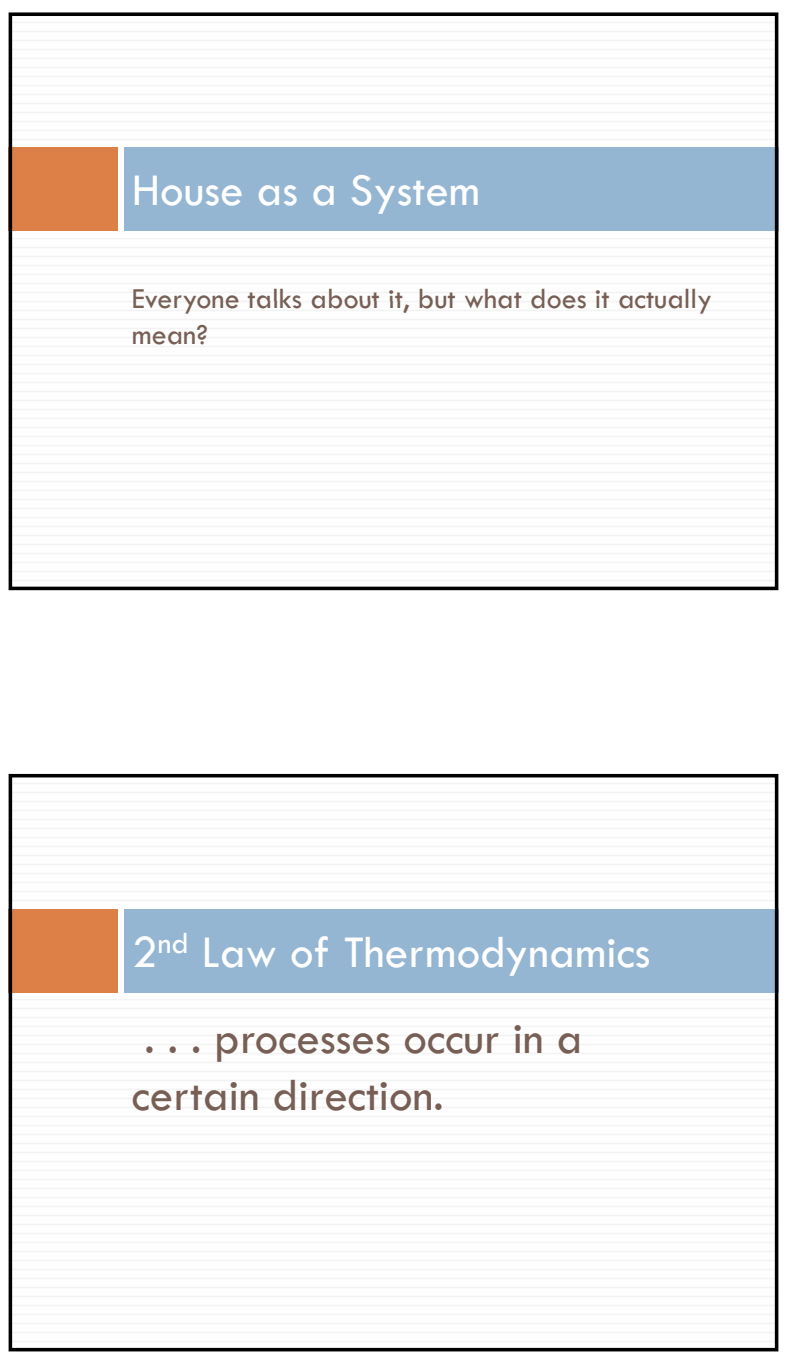

What you need to know most about the $2^{\text {nd }}$ Law...

$\square$ Heat moves to cold

$\checkmark$ Air moves from high pressure to low pressure

$\square$ Moisture moves from higher concentrations to lower concentrations 

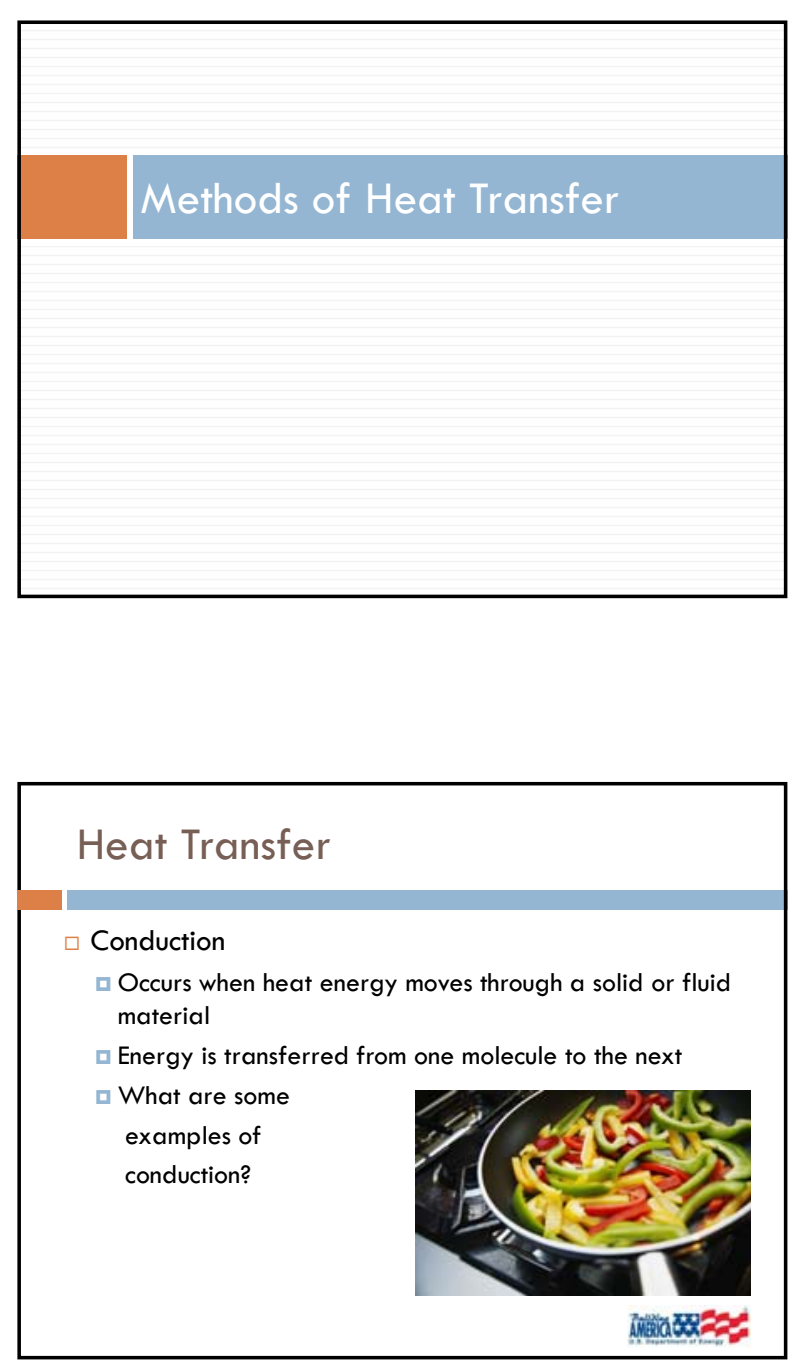

\section{Example: Convection}

$\square$ Convection in homes usually occurs when air in the house moves around due to temperature gradients

$\square$ Warm air is lighter (i.e. less dense) than cold air

$\square$ Cold air falls, warm air rises

\section{Heat Transfer}

Heat is a form of energy

$\square$ When heat moves from place to place, it is referred to as "Heat Transfer"

$\square$ Heat Transfer occurs in three ways:

- Conduction

$\square$ Convection

$\square$ Radiation

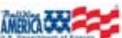

\section{Heat Transfer}

\section{$\square$ Convection}

$\square$ Convection occurs when heat is carried from one place to another

$\square$ Convection requires a

"fluid medium"

(i.e. a gas or liquid)

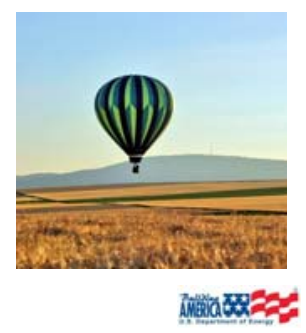

\section{Convective Loops}

When convection occurs in an enclosed space, the air (or fluid) will circulate around the space as it is heated and cooled, this is referred to as a convective loop

$\square$ What are some examples of places where convective loops could be found? 


\section{Heat Transfer}

\section{Radiation}

$\square$ Heat that passes spontaneously from a warm body to a cold body

$\square$ The bodies must be in sight of each other but not in contact

Radiation does not

require a "medium" to

carry the heat

a Give some examples

of radiant heat transfer

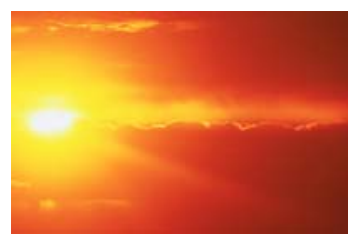

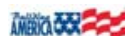

\section{Thermal Boundary}

$\square$ Location of insulation in the building shell

Type of insulation

$\square$ Amount of insulation (thickness and $\mathrm{ft}^{2}$ )

$\square$ Quality of installation (good, fair, poor)

$\square$ Is insulation protected from wind-washing?

$\square$ Is insulation protected from moisture?

\section{What is the conditioned boundary?!!!!}
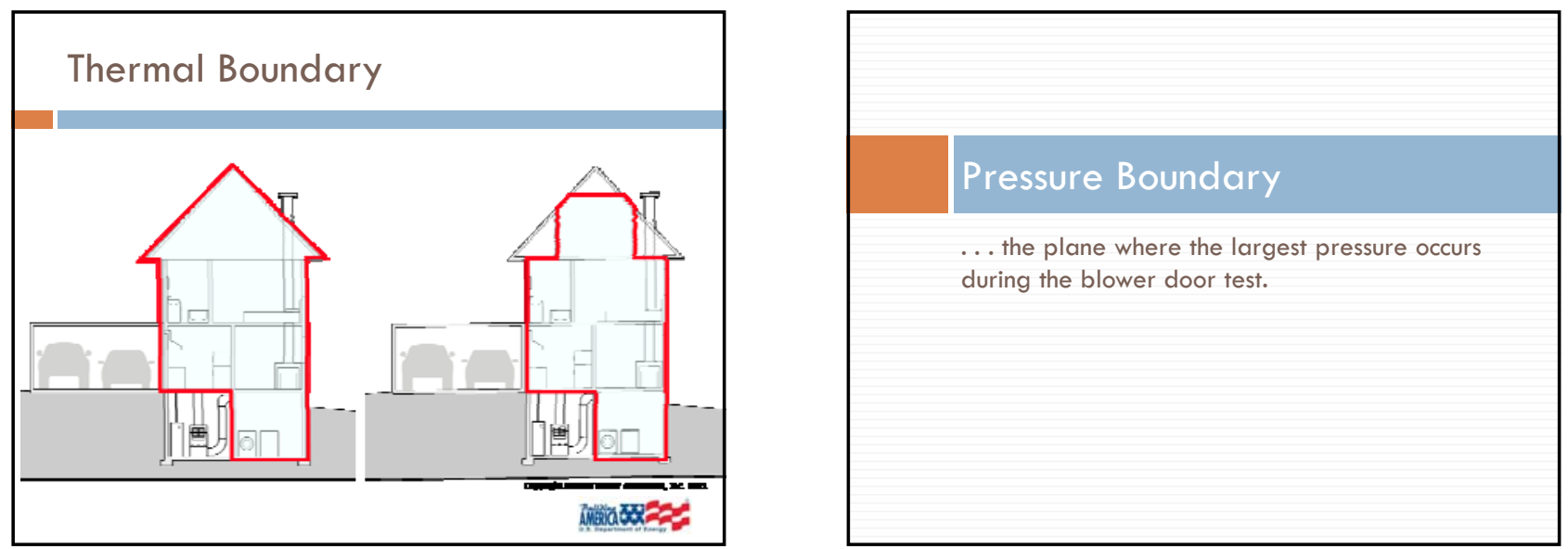


\section{Pressure Boundary} infiltration and exfiltration, the pressure boundary must be continuous.

$\square$ For maximum effectiveness, the pressure boundary and thermal boundary should be in the same plane.

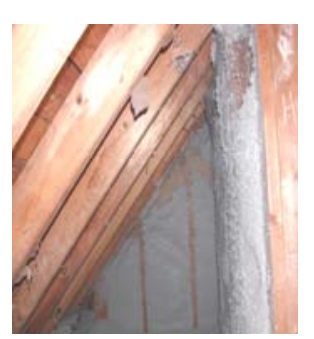

\section{Thermal and Pressure Boundaries}

To function properly and protect the home, they must be:

$\square$ Continuous (no gaps)

$\square$ Aligned with each other
In order to control

\section{Thermal and Pressure Boundaries}

$\square$ The two boundaries work together to manage
energy, moisture, and comfort
$\square$ Energy Control $=\$ \$ \$$ saved
$\square$ Moisture Control = building durability
$\square$ Comfort Control = happy customers

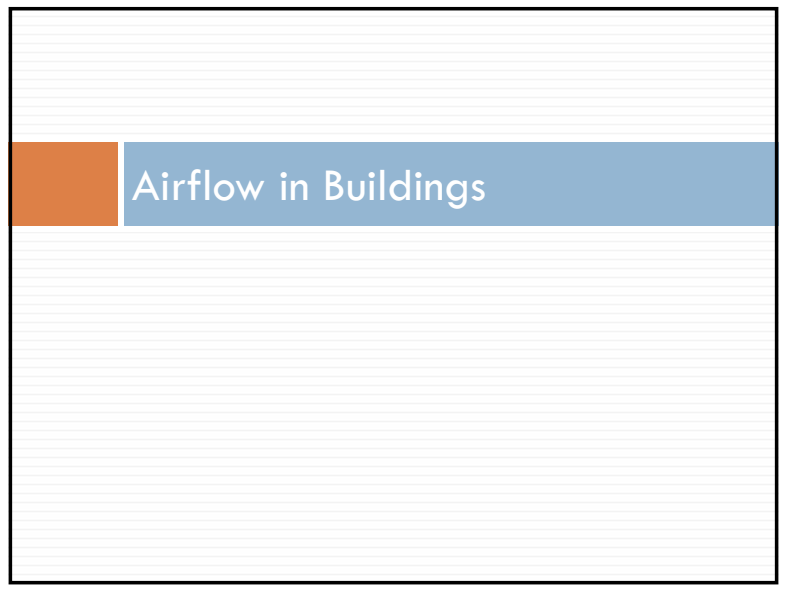

\section{Airflow in Buildings}

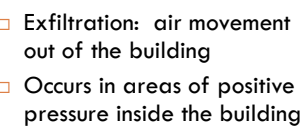

Exfiltration: air movement out of the building

Occurs in areas of positive pressure inside the building into the building

pressure inside of negativ

$\square$ Pressure

口 Pascal

Flow

$\square$ Cubic Feet per Minute (CFM) 

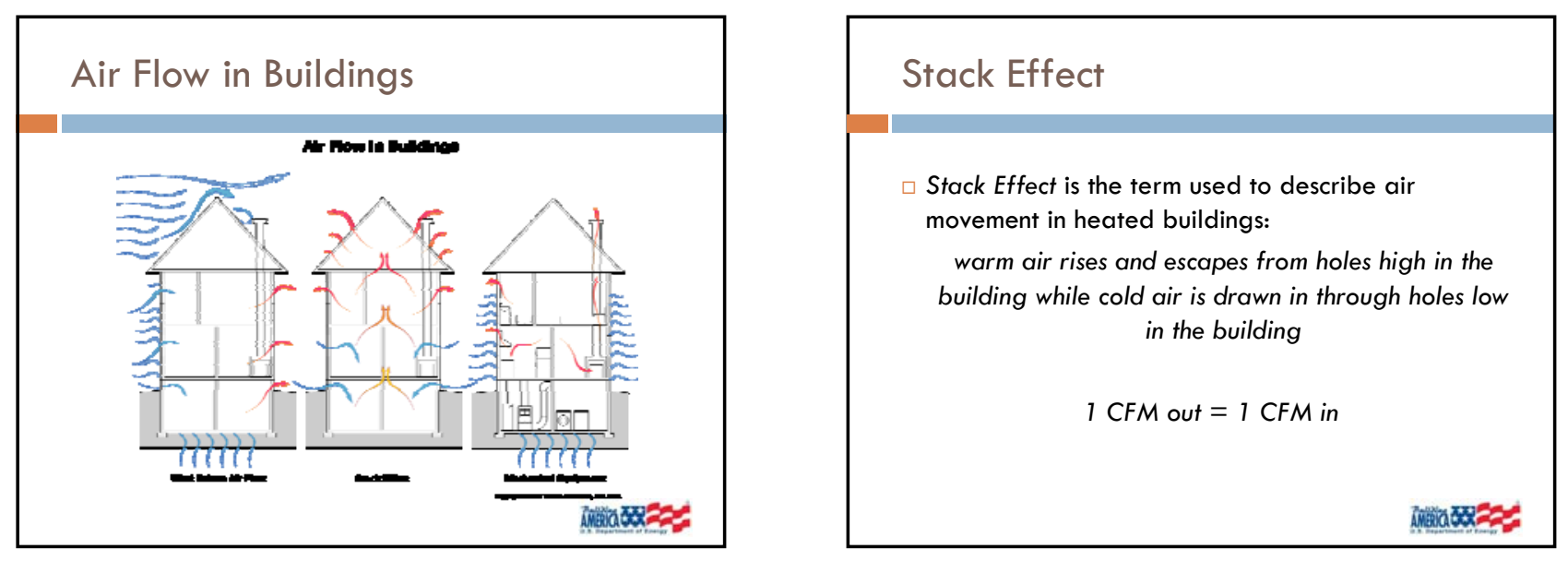

\section{Exhaust Appliances}

$\square$ Exhaust appliances cause depressurization of the living space

$\square$ Venting of combustion appliances can have the same effect

$\square$ When the house is depressurized, even at small pressures, infiltration will occur

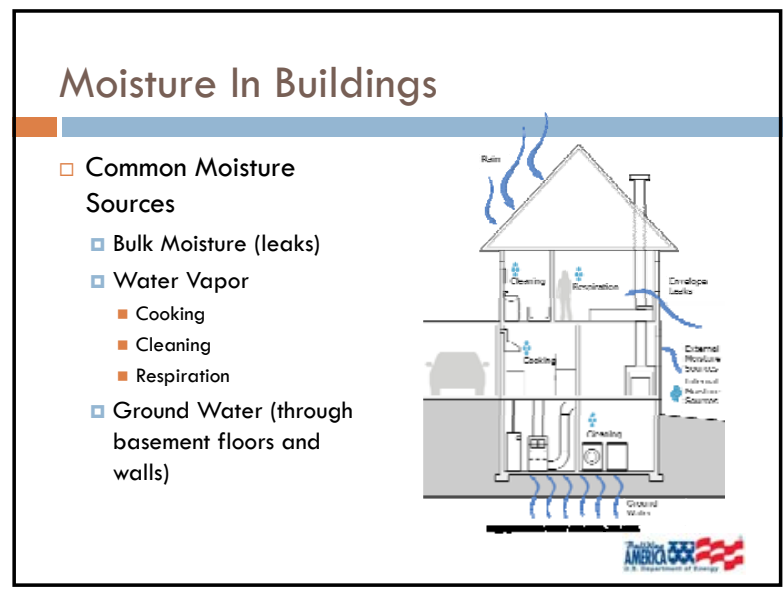

\section{Moisture Transport}

$\square$ Moisture moves around buildings in all of the following ways:

$\square$ Bulk moisture transfer (including capillary action through porous materials)

$\square$ Diffusion

$\square$ Airborne moisture movement

$\square$ Which one do you think causes the most problems in homes? 

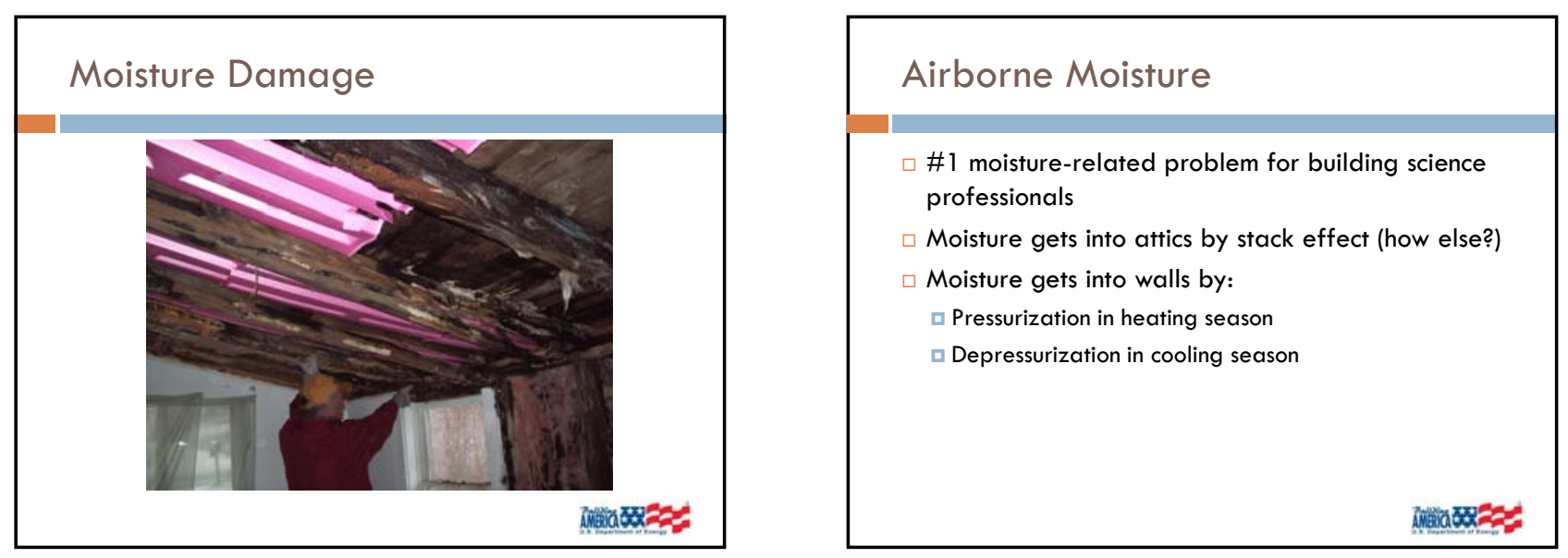

\section{Airborne Moisture - Control}

Reduce/eliminate sources - fix drainage around building, fix leaks into building

$\square$ Properly ventilate high moisture spaces - kitchens, baths, laundry

$\square$ Use whole-house mechanical ventilation - eliminate moisture from people, pets, etc.

\section{Why Air Seal?}

Comfort
Efficiency
Moisture
Indoor air quality (IAQ)

\section{Air Sealing Materials}

\section{$\square$ Spray foam}
- 1-Part
$\square$ 2-Part
$\square$ Caulk
$\neg$ Rigid Foam Board
$\square$ Drywall
$\square$ Thick Plastic
$\square$ Cardboard?
$\square$ Basically, anything that will stop air 


\section{Air Sealing Priorities}

Stop the Stack Effect!

$\square$ Go after biggest holes first, duh

$\square$ Top of the house is usually first priority

$\square$ Basements and Crawlspace next

$\square$ Main house last, if even necessary

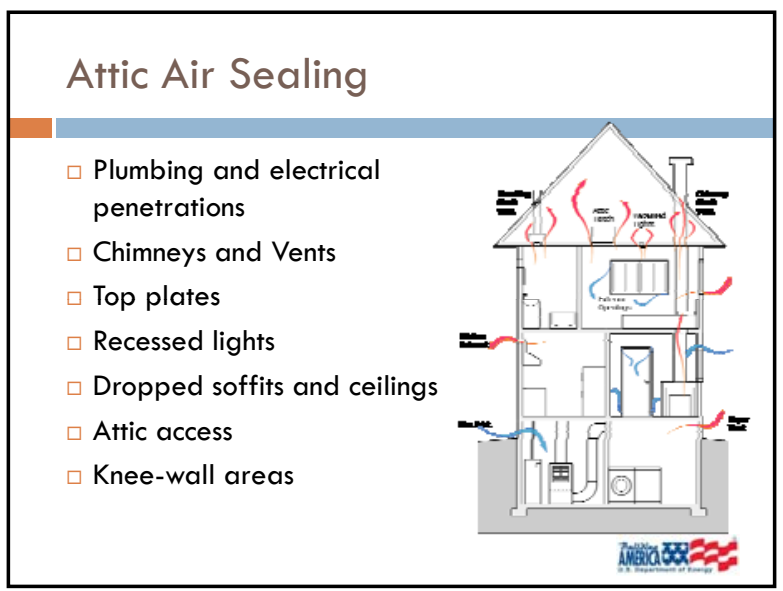

\section{P \& E Penetrations}
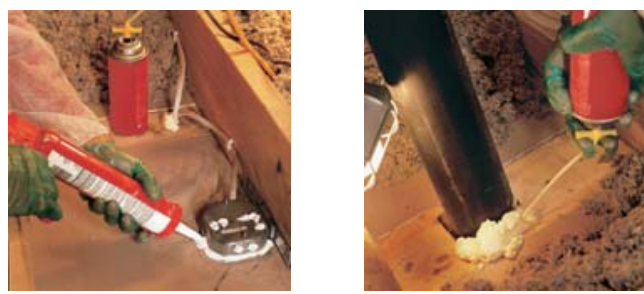

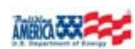

Chimneys and Flue Vents

High Temperature surfaces require special considerations

- Can not have combustible materials (i.e. spray foam, most insulations) in contact with high temp surfaces

Sheet metal, high temp caulk, and rockwool are good alternatives

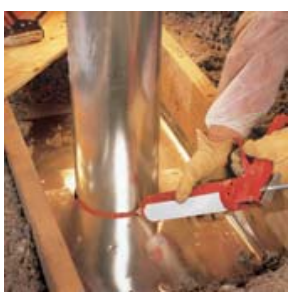

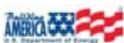

\section{Dropped soffits and ceilings}

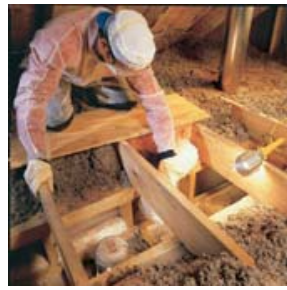

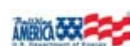

\section{Knee-wall areas}

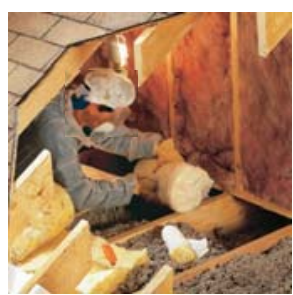

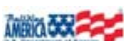




\section{Basement/Crawl Space Sealing}

Rim joists/sill plates

Exterior penetrations

$\square$ Floor penetrations

\section{Floor Penetrations}

Electrical and plumbing penetrations

$\square$ Under tubs and showers

$\square$ HVAC duct penetrations
Rim Joists/Exterior Penetrations

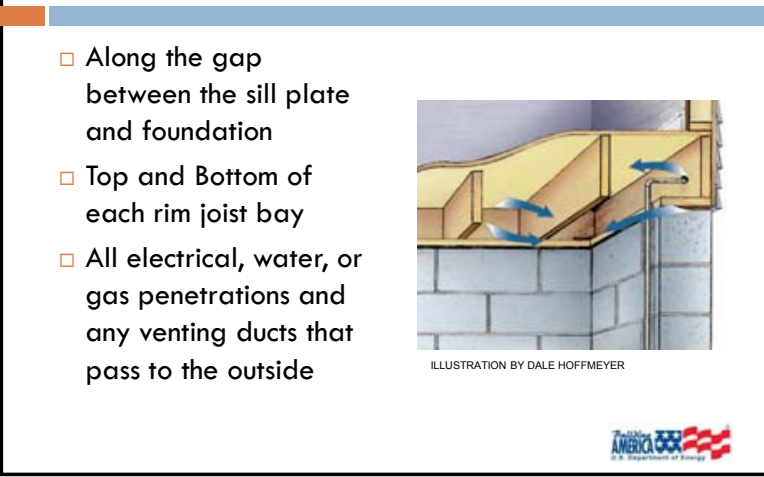

\section{Main House Air Sealing}

$\square$ Caulk Baseboards

$\square$ Weather-strip doors and windows

$\square$ Caulk around door and window trim

$\square$ Foam plumbing penetrations beneath sinks

$\square$ Gasket electrical outlets

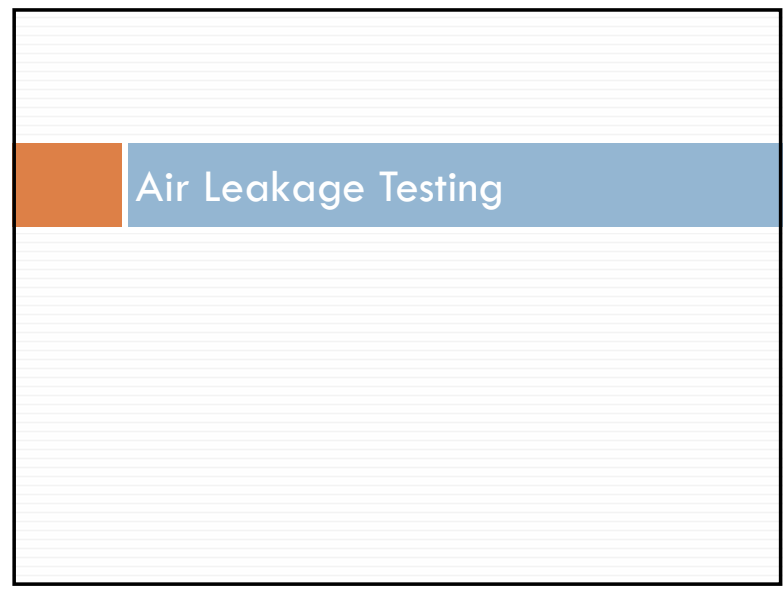

\section{Using a Blower Door}

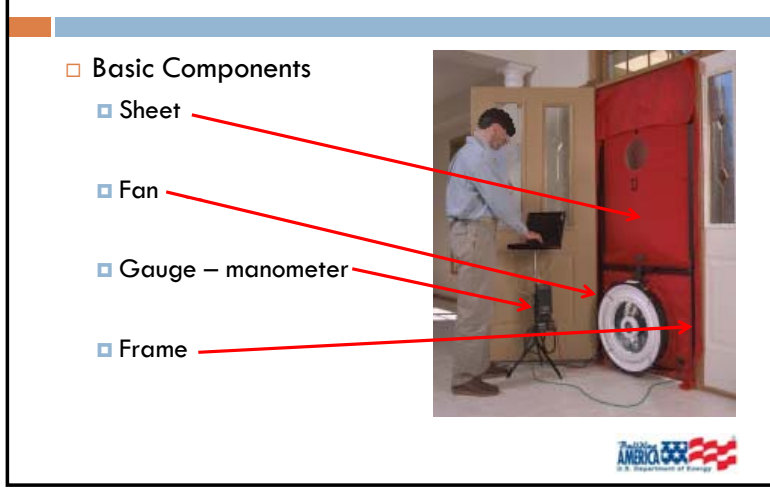




\section{Using a Blower Door}

House Preparation

$\square$ Open doors to conditioned space

- Make sure all registers are open and uncovered

- Turn off ALL fans.

$\square$ Tape off any openings for mechanical ventilation that runs automatically and continuously.

$\square$ Turn heating and air conditioning systems off.

a Turn gas water heating equipment to pilot. Leave your car keys.

$\square$ Turn off the emergency switch for oil \& gas equipment.

\section{Using a Blower Door}

\section{$\square$ House Preparation (cont.)}

$\square$ Close fireplace dampers and remove or cover ashes.

$\square$ Close and lock all windows including storms.

口 Close adjustable trickle \&/or through the wall vents.

- Seal evaporative cooler openings if a cap is used.

口 Fill plumbing traps with water if air is coming out.

口 Seal window air conditioners that are removed in winter.

- If you suspect asbestos is present, do not do a blower door.

- When finished, remove tape, put thermostats back to original settings and turn on heating and hot water.

Antomiches

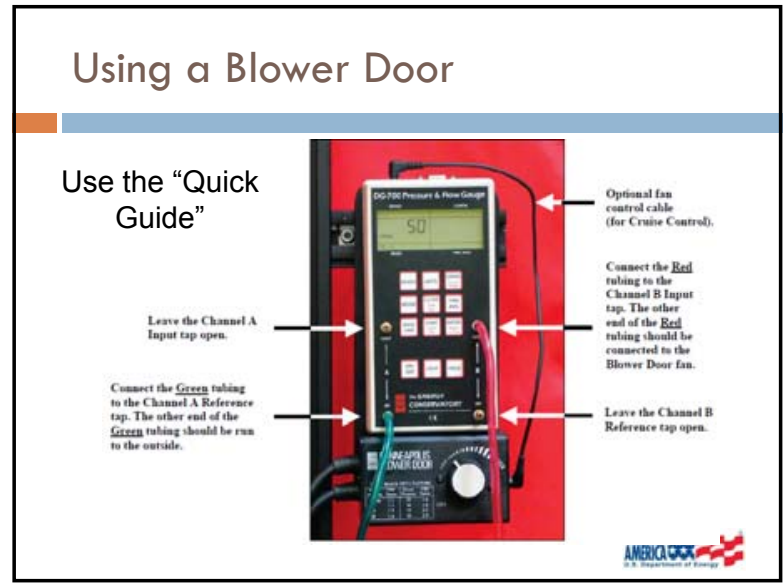

\section{Using a Blower Door}

\section{Blower door tells you:}

$\square$ Air changes per hour (ACHn) - How many times per hour the air in the house is exchanged with outside air $\square$ Where major leaks are

$\square$ If unconditioned buffer zones are inside or outside of the house

$\square$ Areas you should concentrate on when air sealing - High \& low holes

- Biggest holes

ㅁ If mechanical ventilation should be added

\section{Using a Blower Door}

$\square$ Check your readings against:

a Typical flows in table on Quick Guide

$\square$ Against pressure/flow tables in back of manual

\begin{tabular}{|l|r|}
\hline Fan Configuration & $\begin{array}{c}\text { Flow Range (cfm) } \\
\text { for Model 3 Fan }\end{array}$ \\
\hline Open (no Flow Ring) & $6,300-2,430$ \\
\hline Ring A & $2,800-915$ \\
\hline Ring B & $1,100-300$ \\
\hline Ring C & $330-85$ \\
\hline
\end{tabular}

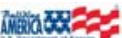

\section{Air Sealing and Ventilation}

$\square$ Can we make a building too tight?

$\square$ Air sealing keeps energy in, but also keeps $\mathrm{CO} 2$, moisture, and pollutants in

$\square$ Every house requires a certain air exchange rate to maintain healthy indoor air quality 


\section{Air Sealing and Ventilation}

Building tightness limits, based on volume and \# of occupants

$\square$ Converted into CFM50

$\square$ If blower door reading falls below the BTL, mechanical ventilation must be installed

$\square$ "Build tight, ventilate right"

$\square$ Better to control where our fresh air is coming from than to let the house decide

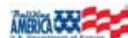

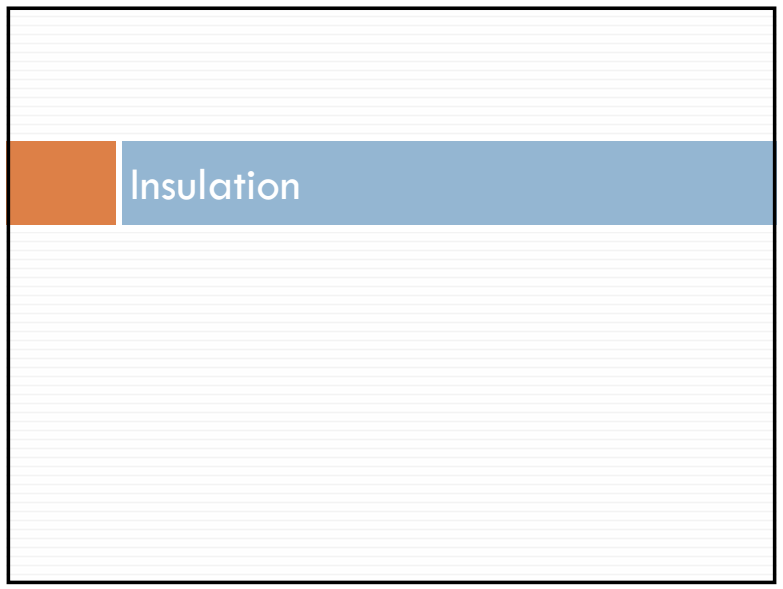

R-value $\left(\mathrm{h} \cdot \mathrm{ft}^{2}{ }^{\circ} \mathrm{F} / \mathrm{Btu}\right)$

R-value is a measurement of a material's resistance to conductive heat transfer

$\square$ The higher the Rvalue, the better the insulator

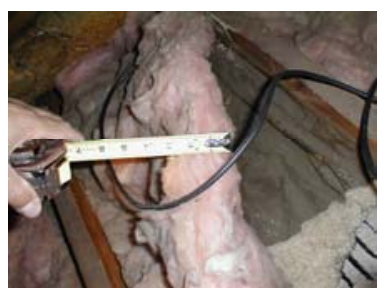

\section{R-values of Common Insulations}

\section{Insulation}

$\square$ Why is insulation light and fluffy?

$\square$ Small pockets in insulation trap still air

$\square$ The air is the insulator!
What Air Movement Does to Insulation...

$\square$ When air moves through insulation, there are no more still air pockets

$\square$ As a result, the effective $R$-value is reduced

$\square$ Remember:

$\square R$ per inch of wood $\approx 1.2$

$\square R$ per pane of glass $<1.0$ 
Other Factors Affecting Insulation Performance

Compression (refer to manufacturer's compression charts)

$\square$ "Fluffing", especially blown fiberglass

$\square$ Voids and gaps, inconsistent coverage

$\square$ Moisture

$\square$ Not in contact with the surface it is insulating
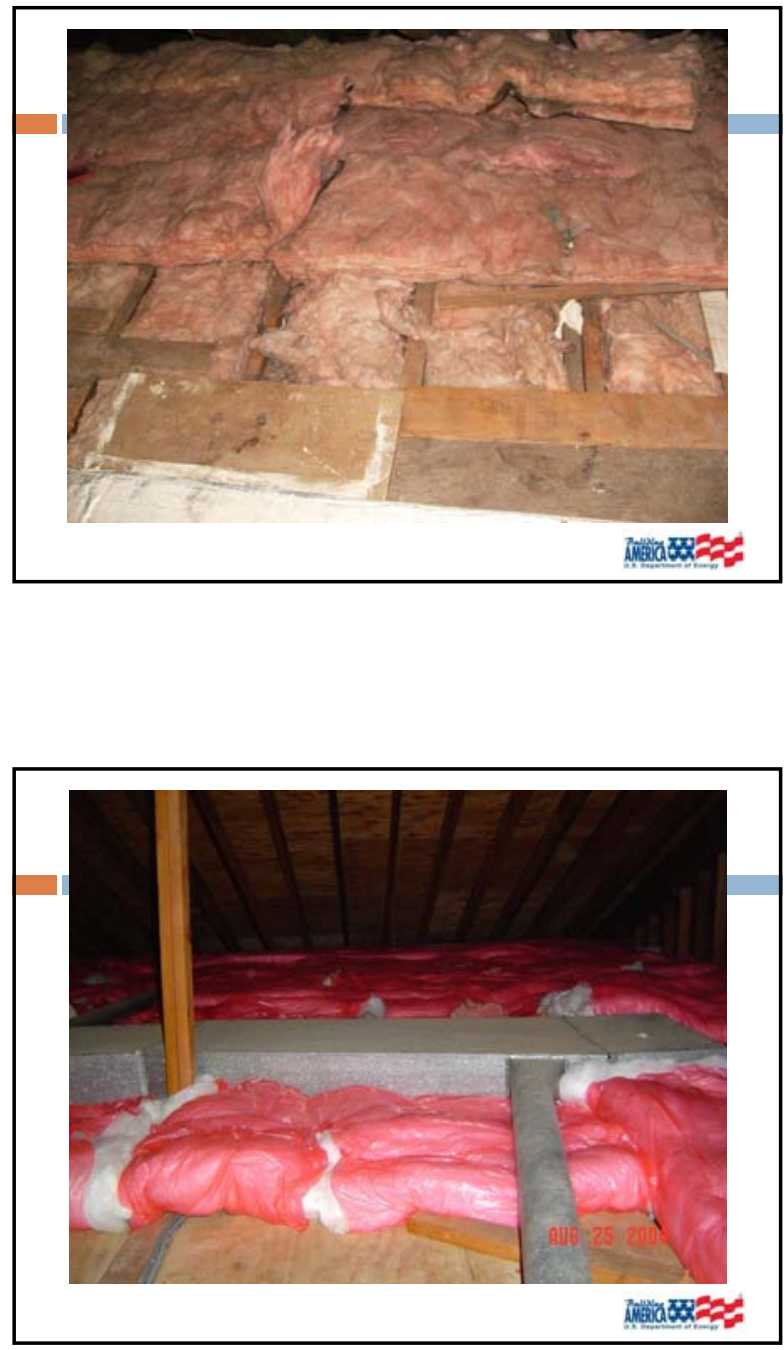
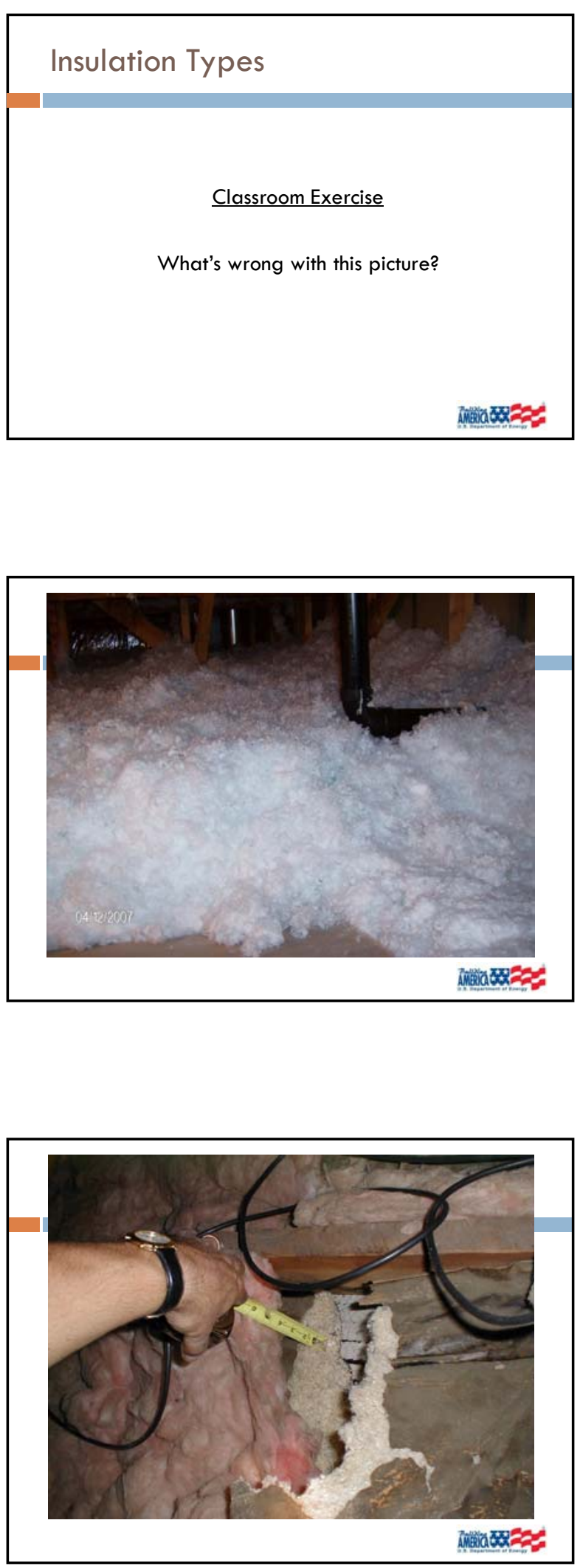

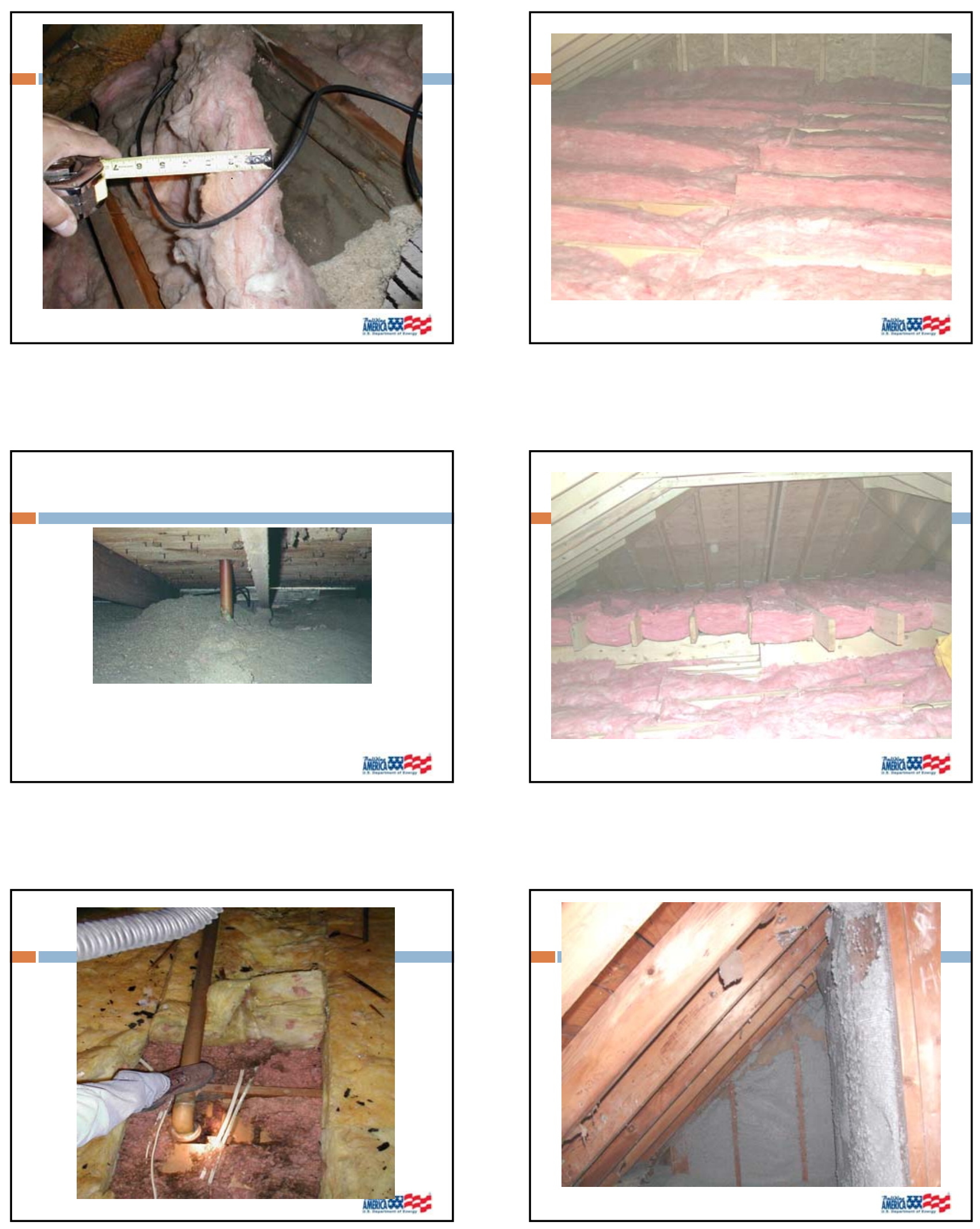

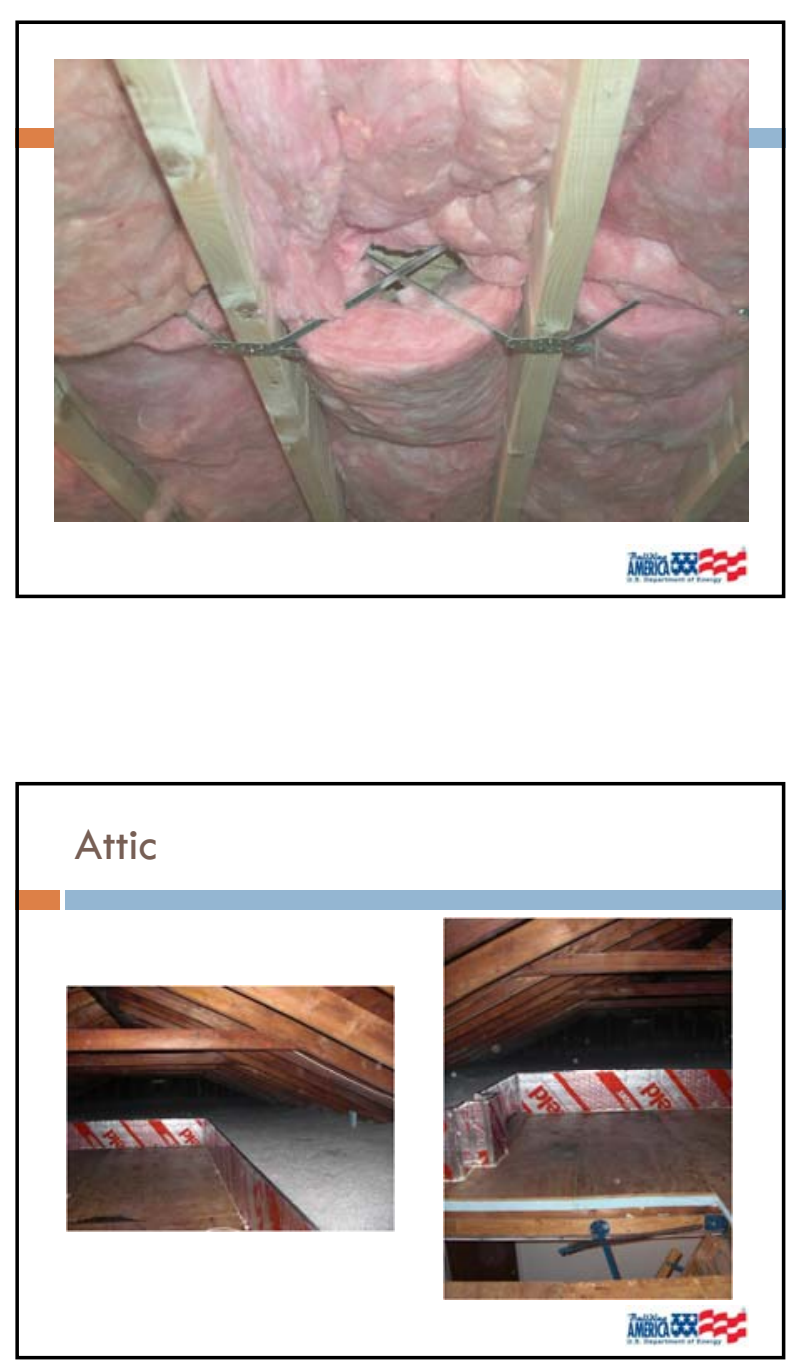

\section{Insulating Crawl Spaces}

To vent, or not to vent. That is the question.

$\square$ Code used to mandate venting crawl spaces, in order to remove moisture

$\square$ But....usually the opposite occurs

$\square$ Why?

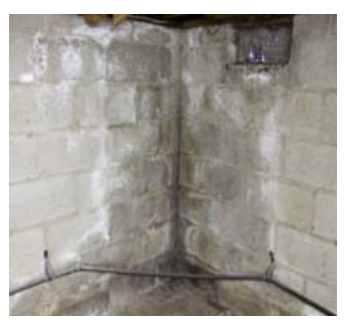

What does a good Insulation job look like?

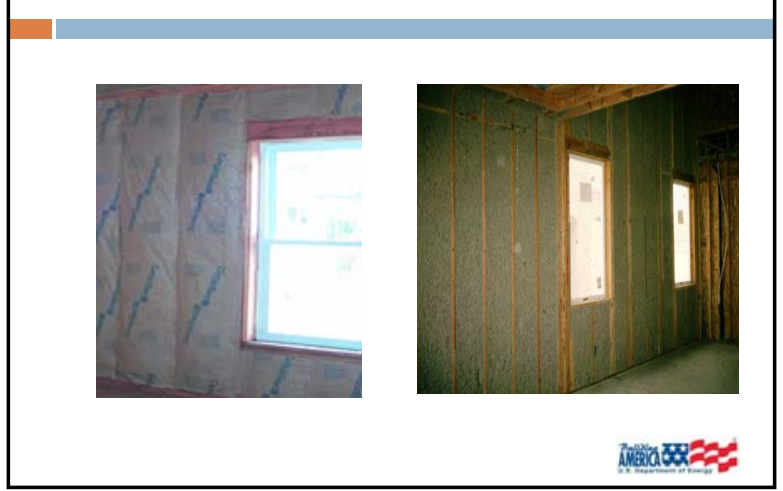

\section{Attic Hatches}

$\square$ One of the weakest points in the thermal envelope

$\square$ Gasket opening

$\square$ Insulate with Rigid Foam

$\square$ Add drywall or plywood for weight

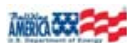

\section{Insulating Crawl Spaces}

$\square$ Crawl Spaces generally should be unvented, conditioned areas

$\square$ Vapor Barrier over dirt floors

-Overlapped 6" at seams, taped or sealed

$\square$ Ran at least 6" up the wall and sealed or taped

$\square$ Walls insulated to R-10 minimum

$\square$ Conditioned air supply sized to deliver at a rate of $1 \mathrm{cfm} / 50 \mathrm{ft} 2$ of under-floor area

$\square$ Remove all debris

Tution 


\section{Insulating Crawl Spaces}

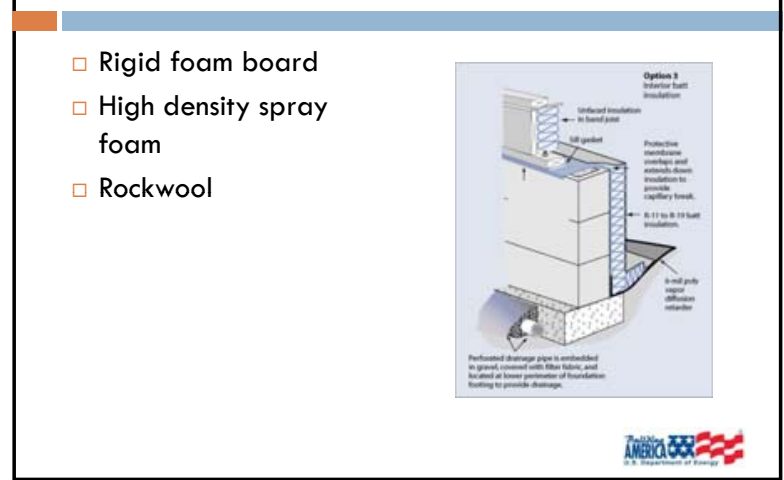

\section{Knee Wall Areas}

Knee wall areas can either be brought into conditioned space or excluded from conditioned space

$\square$ Insulate roof rafters to bring into conditioned space

$\square$ Insulate walls and floor to exclude from conditioned space

\section{Insulating Crawl Spaces}

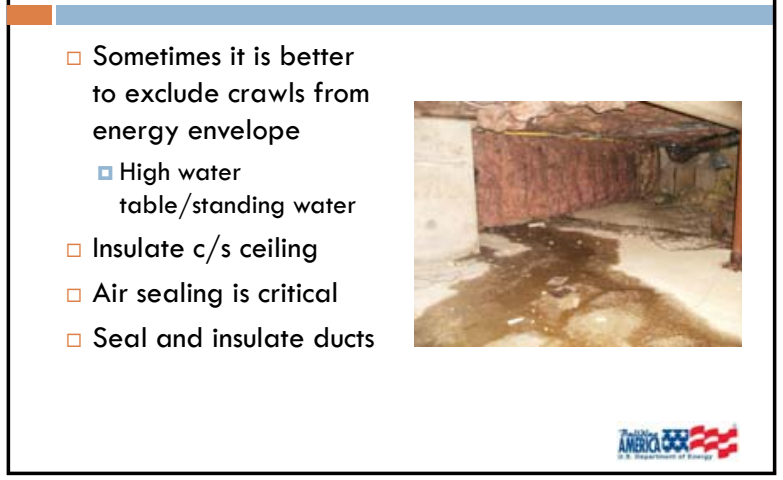

\section{Knee Walls}

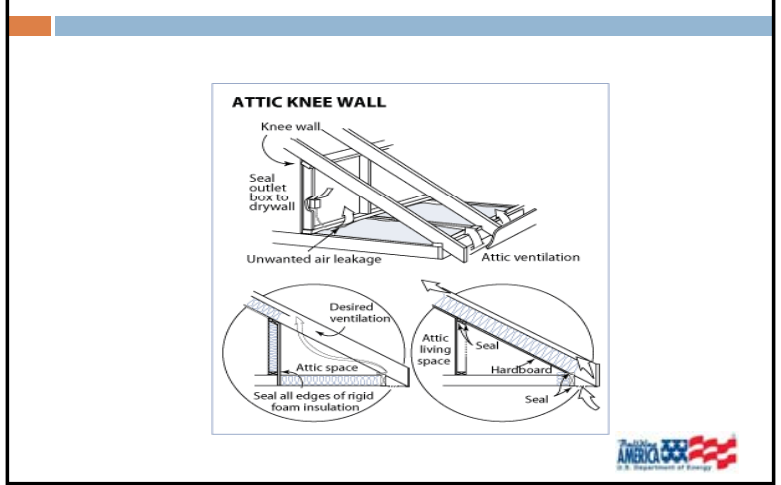

\section{NFRC Label}

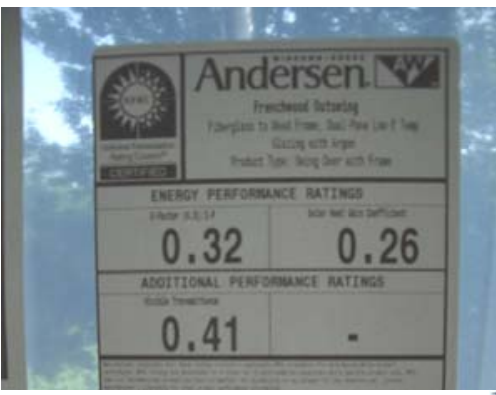




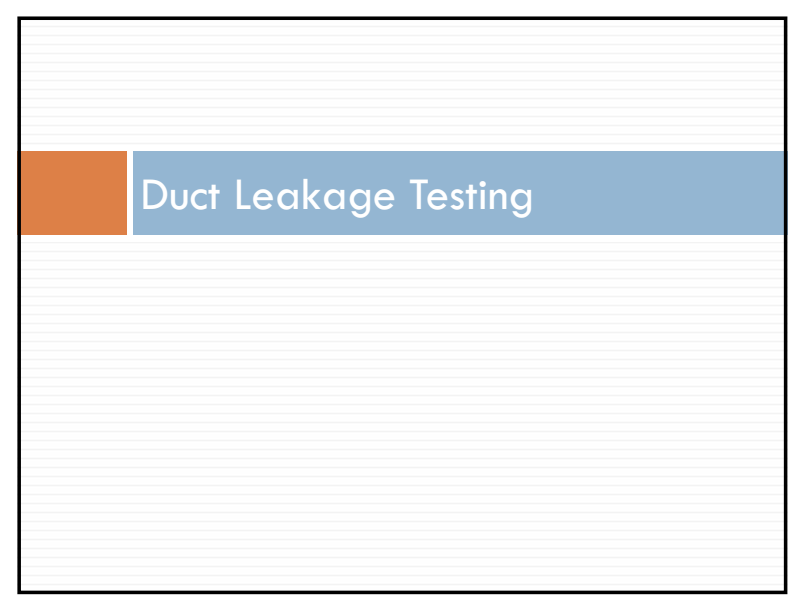

\section{Duct Leakage Testing}

$\square$ Configure the house for an air leakage test

$\square$ Determine if the air handler is inside or outside the conditioned space

$\square$ Remove the system air filter.

$\square$ Select an appropriate location - at air handler or return closest to air handler

$\square$ Set up the pressure hoses - if gauge is "outside" the conditioned area, run hose to the conditioned space

$\square$ Seal all supply and return registers

\section{Duct Sealing}

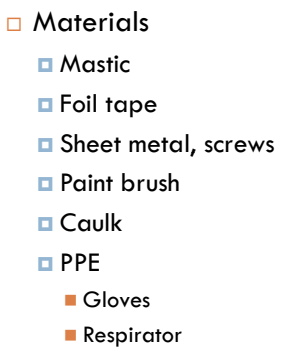

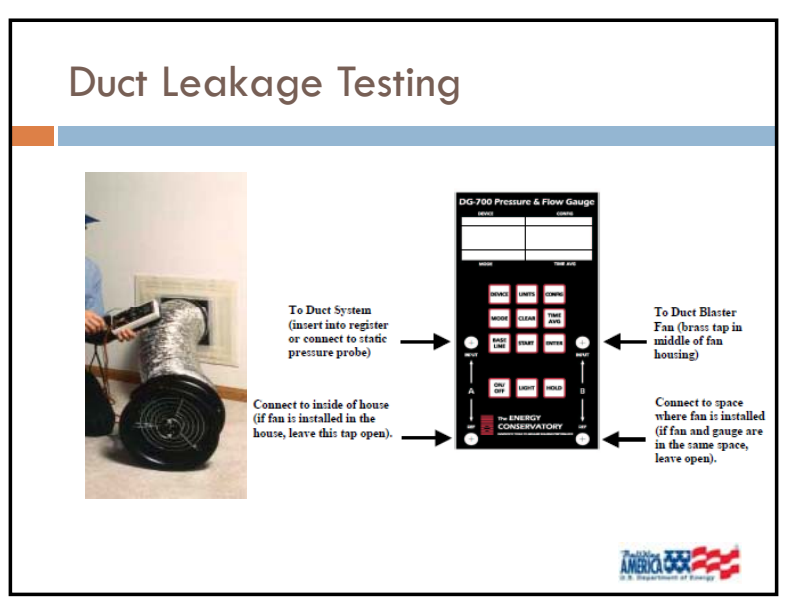

\section{Duct Leakage Testing}

$\square$ Open unconditioned zones to outside as much as possible.

$\square$ Using the blower door, pressurize the house to 25 Pascals.

$\square$ Pressurize the duct system until the pressure in the supply duct is 0 .

$\square$ Record testing equipment fan pressure and ring used

$\square$ Record the duct blaster fan airflow. This is your duct leakage to outside.

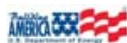

\title{
Duct Sealing
}

\author{
$\square$ Priorities \\ $\square$ Biggest holes \\ $\square$ Leaks closest to Air Handler \\ $\square$ Duct Joints \\ $\square$ Panned Returns \\ $\square$ Boot connections \\ $\square$ Filter Slot \\ $\square$ Air Handler cabinet
}



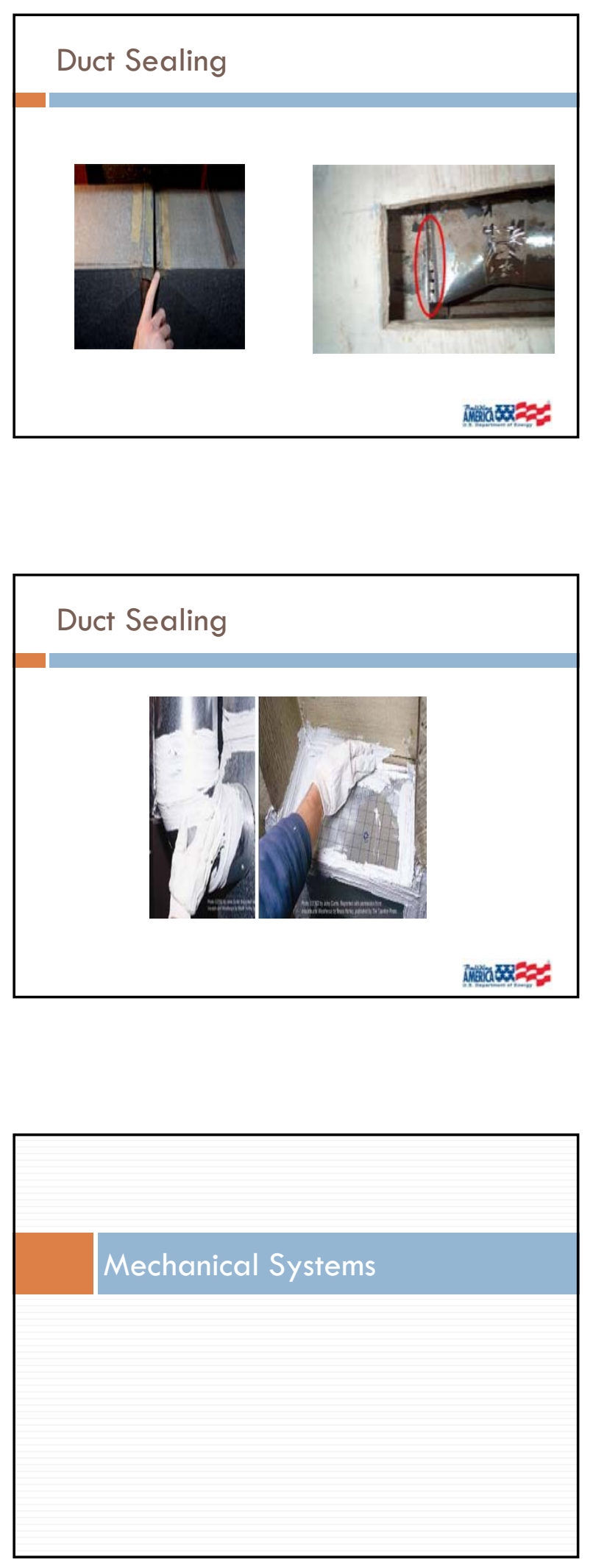

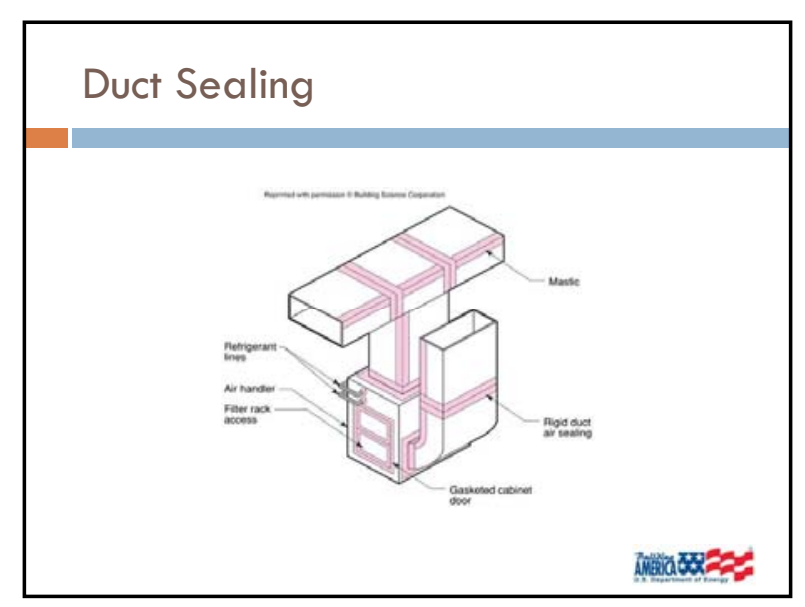

Duct Sealing

$\square$ Panned Returns

$\square$ Uses stud and joist bays as the return chaseway

$\square$ Best Solution: Replace with a fully ducted return

$\square$ Next Solution: Use screws to fasten sheet metal, then mastic and/or tape to fully seal seams

$\square$ Filter slots

$\square$ Filter should be right sized

$\square$ Best practice to build a removable slot cover out of sheet metal

$\square$ Tape?

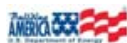

\section{Combustion Science}

$\square$ Elements needed for combustion

$\square$ Fuel - gas, oil, wood, propane, etc.

$\square$ Oxygen

$\square$ Heat Source

$\square$ By-products

$\square$ Water $\left(\mathrm{H}_{2} \mathrm{O}\right)$

$\square$ Carbon Dioxide $\left(\mathrm{CO}_{2}\right)$

$\square$ Incomplete combustion leads to Carbon Monoxide (CO) 

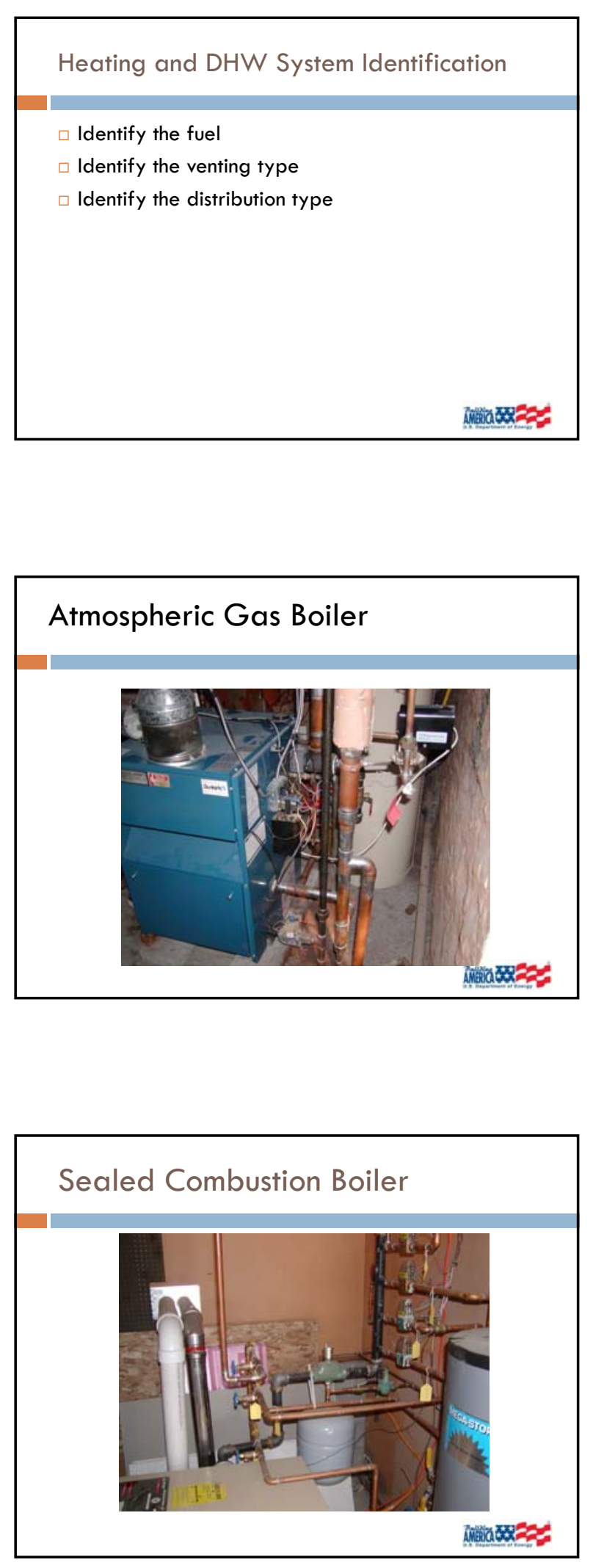
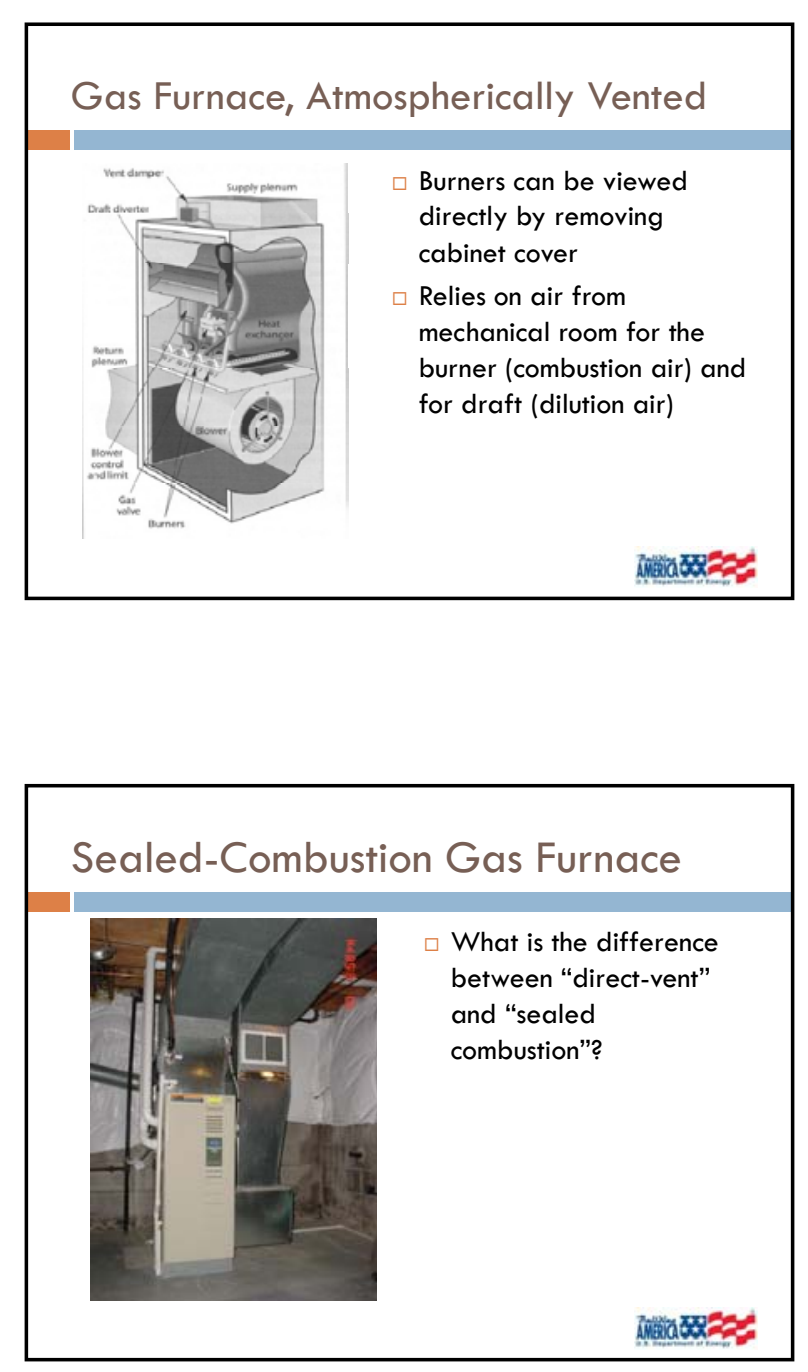

Hydro-Air Furnace

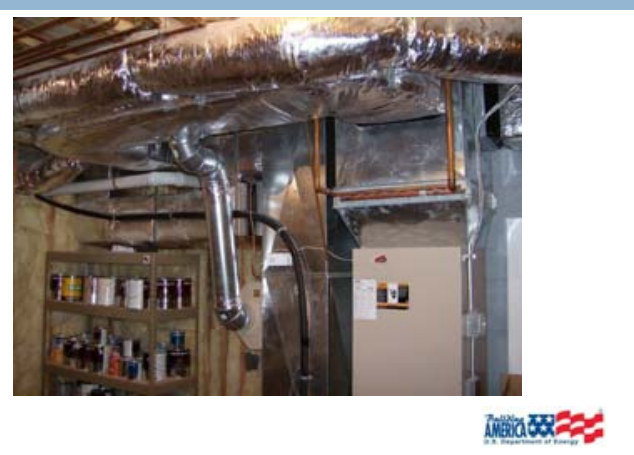



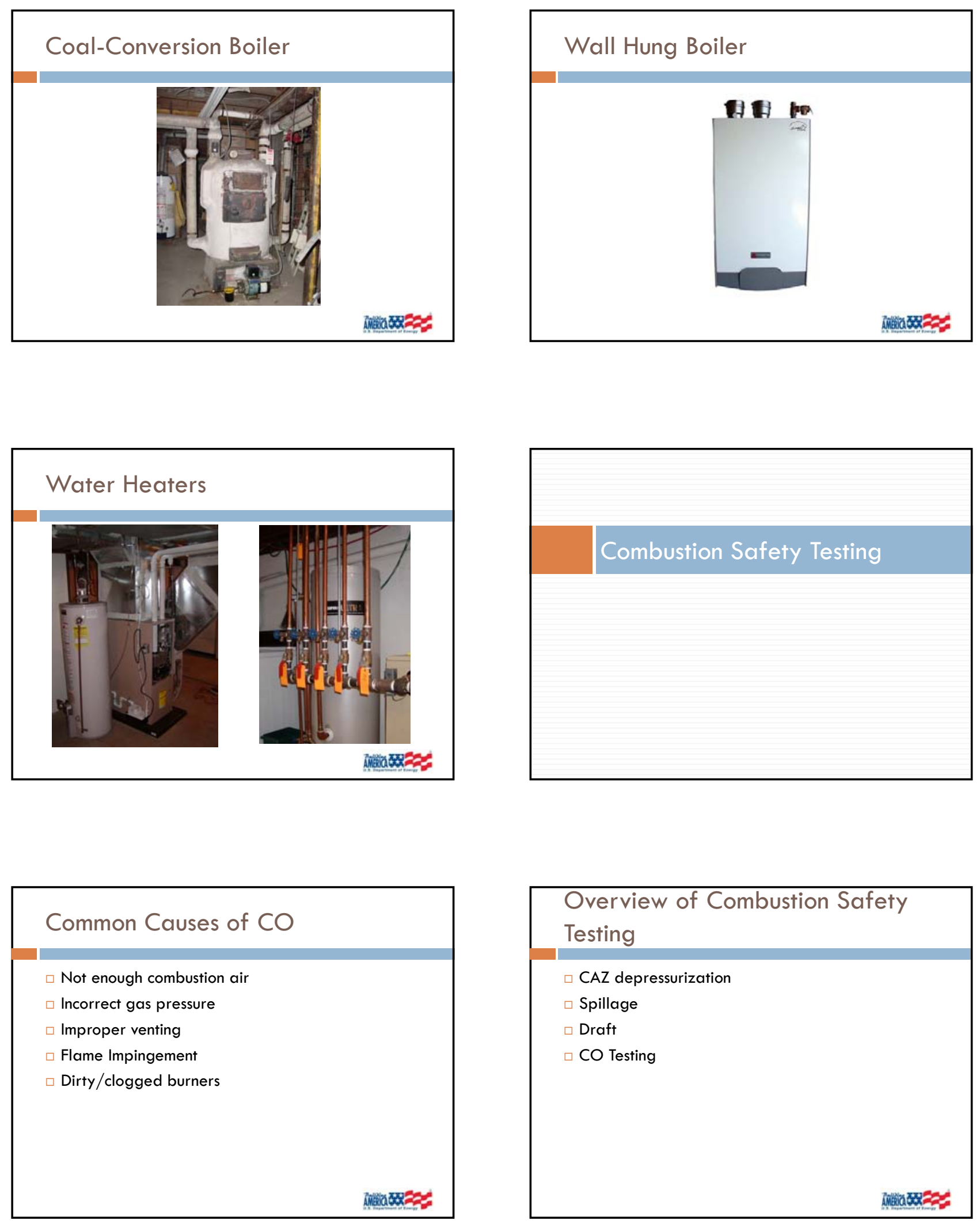


\section{Why is CO Dangerous?}

Hemoglobin normally bonds with oxygen and distributes $\mathrm{O}_{2}$ throughout your body.

$\square$ When $\mathrm{CO}$ is inhaled, it combines with hemoglobin with a bond that is 200 times stronger than its normal bond with $\mathrm{O}_{2}$.

$\square$ Carbon monoxide poisoning deprives your body's cells of oxygen.

\section{Other Sources of CO}

Don't forget that CO can be produced in other parts of the home, including:

$\square$ Woodstoves/fireplaces

$\square$ Attached garages

$\square$ Electric stoves on the cleaning cycle

\section{CO Detectors}

A CO detector is recommended on every floor

$\square$ CO detectors shall be UL-2034 compliant and installed in accordance with manufacturer's recommendations

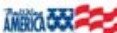

\section{Example of CAZ Depressurization}

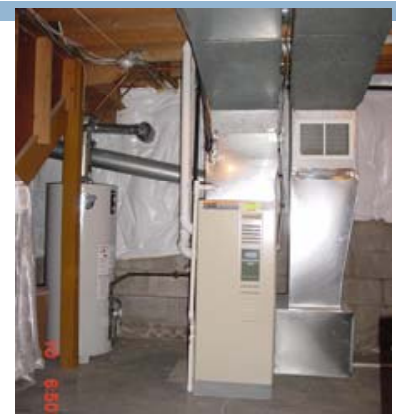

a
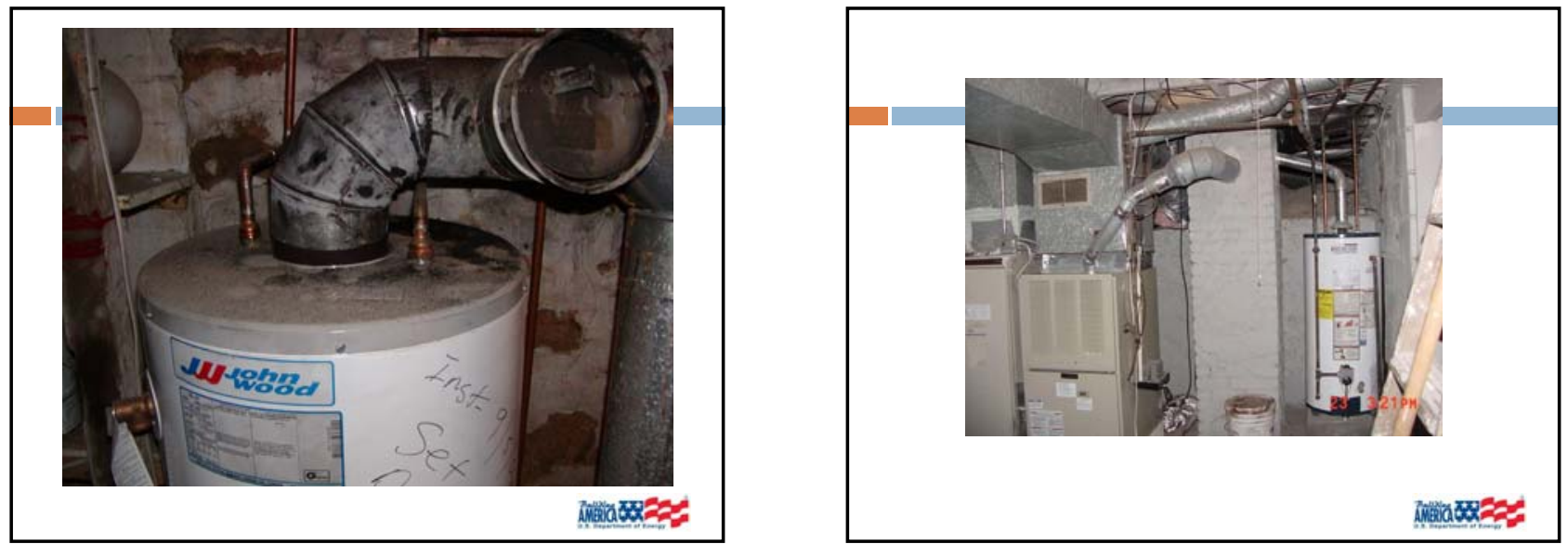


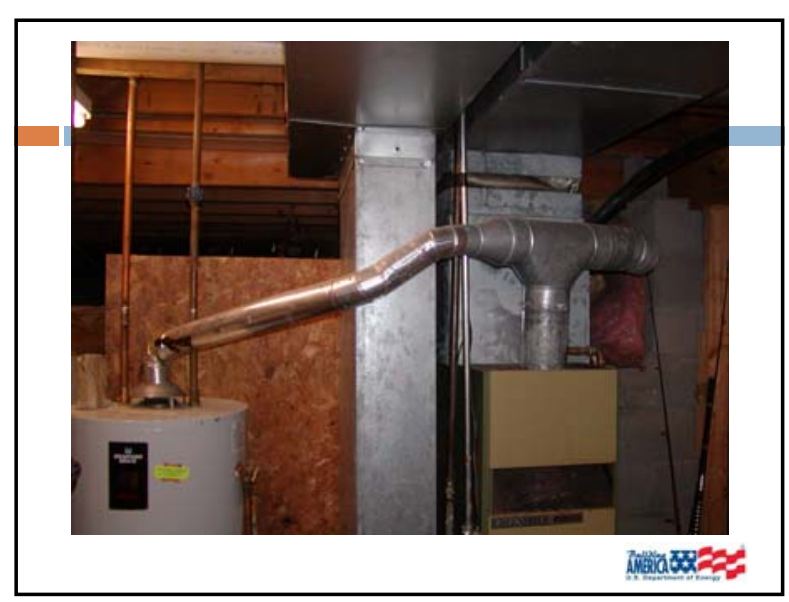

\section{Spillage}

Check for spillage upon startup of combustion appliances

$\square$ Use stopwatch to record time elapsed before draft is established

$\square$ Use smoke around draft hood to verify spillage has ceased

$\square$ Draft should be established within 1 minute

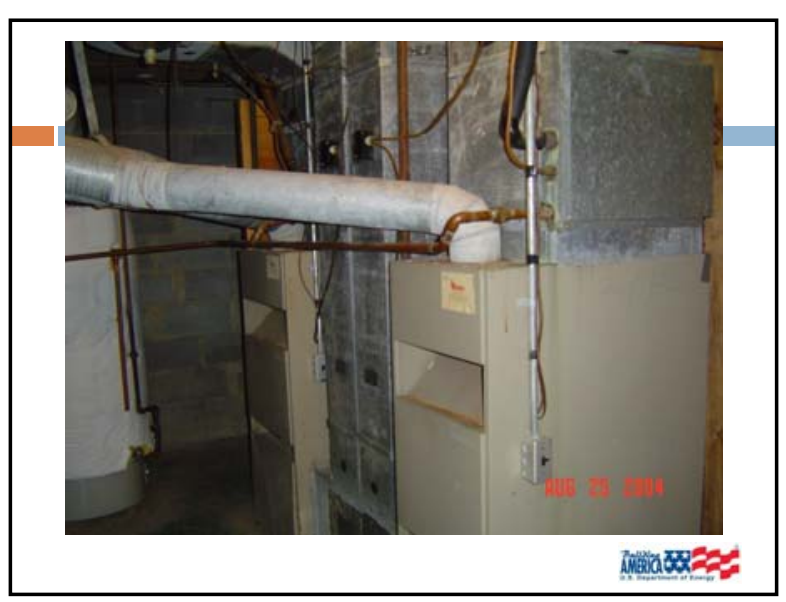

Check Draft Diverter for Signs of Spillage

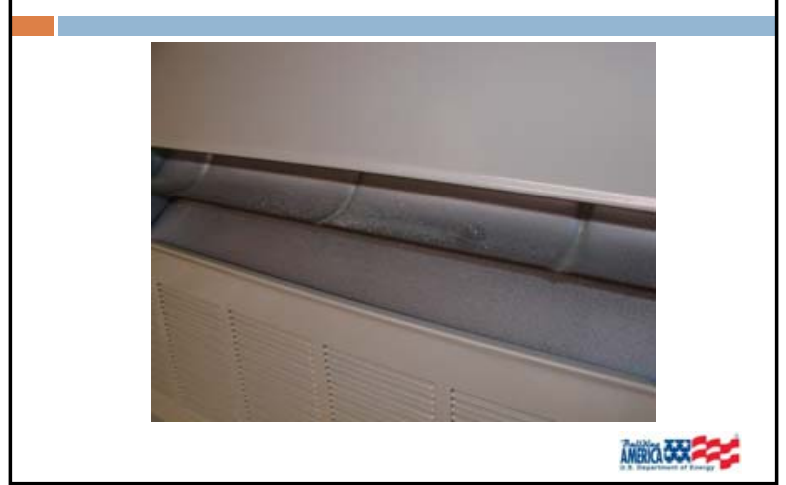

Turbulator Divides Flue Into 2 Chambers

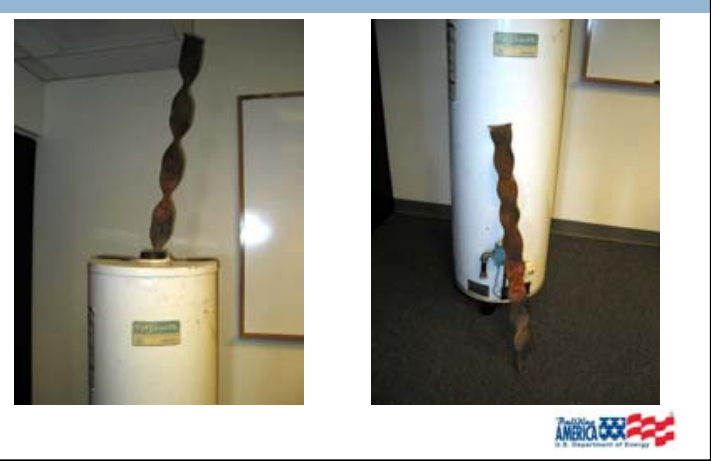




\section{Draft}

Draft is flow of gases up the flue

$\square$ Atmospheric relies on gravity - very weak, easily reversed

$\square$ Depends on temperature of flue, outside temperature \& chimney height

\section{Testing Multiple Appliances}

Multiple appliance will affect draft

Smaller appliances will piggy-back off larger

$\square$ Changing out an appliance $w /$ out changing flue can affect draft

\section{Carbon Monoxide Testing Procedures}

Ambient $\mathrm{CO}$ should be monitored throughout the entire combustion safety testing procedure

$\square$ If Ambient $\mathrm{CO}$ exceeds $35 \mathrm{ppm}$ at any time, the test should be stopped, appliances shut down, and the space ventilated before continuing

$\square$ The appliance should be adjusted/repaired prior to repeating the test

\section{Special Concerns with Furnaces}

$\square$ Wherever ductwork is present in the $C A Z$, take care to determine how duct sealing will effect the performance of the combustion appliances (creating negative or positive pressures in the zone) 


\section{References}

Joint Center for Housing Studies (JCHS); 2006; “America's Rental Housing: Homes for a Diverse Nation"; Harvard University, 1033 Massachusetts Avenue, 5th Floor Cambridge, MA 02138; www.jchs.harvard.edu.

Polly, B., Kruis, N., and Roberts, D.; 2011; “Assessing and Improving the Accuracy of Energy analysis for Residential Buildings"; National Renewable Energy Laboratory; Golden, CO.

U.S. Department of Housing and Urban Development (HUD); 2011; "American Housing Survey for the United States 2009: Current Housing Reports” Issued March 2011, H150/09; HUD, Office of Policy Development and Research; U.S. Department of Commerce Economics and Statistics Administration; U.S. Census Bureau. 


\section{U.S. DEPARTMENT OF Energy Efficiency \& ENERY Renewable Energy}

